Cinthia Mayumi Saito

\title{
Atividades de lazer: \\ tessitura de espaços para alteridade
}




\section{Cinthia Mayumi Saito}

\section{Atividades de lazer: tessitura de espaços para alteridade}

Dissertação a ser apresentada à Faculdade de Medicina da Universidade de São Paulo para obtenção do título de Mestre em Ciências

Programa de: Ciências da Reabilitação

Área de Concentração: Movimento, Postura e Ação Humana Orientadora: Prof ${ }^{-}$Dra. Eliane Dias de Castro 
Dados Internacionais de Catalogação na Publicação (CIP)

Preparada pela Biblioteca da

Faculdade de Medicina da Universidade de São Paulo

Creprodução autorizada pelo autor

\section{Saito, Cinthia Mayumi}

Atividades de lazer: tessitura de espaços para alteridade / Cinthia Mayumi Saito. -- São Paulo, 2010.

Dissertação(mestrado)--Faculdade de Medicina da Universidade de São Paulo.

Programa de Ciências da Reabilitação. Área de concentração: Movimento, Postura e Ação Humana.

Orientadora: Eliane Dias de Castro.

Descritores: 1.Participação comunitária 2.Atividades de lazer 3.Alteridade 4.Pessoas com deficiência

$\mathrm{USP} / \mathrm{FM} / \mathrm{DBD}-333 / 10$ 


\section{Agradecimentos}

À Eli que orientou este trabalho de maneira tão afetiva; pelo incentivo, investimento e aprendizado de todos esses anos; pelas orientações afetuosas e acolhedoras; por sustentar comigo as árduas escolhas deste caminho, buscando sempre abrir espaço para o criativo e para as conexões com a vida.

À equipe do Laboratório de Estudo e Pesquisa Arte e Corpo em Terapia Ocupacional, especialmente Erika Inforsato e Beth Lima, pelas produções que inspiram e dão força.

Às professoras Maria Inês Brunello, Eucenir Fredini Rocha e Sílvia Cristina Franco Amaral pelas leituras e contribuições na banca de qualificação.

Aos companheiros de pós, pela contribuição nas discussões e partilha das experiências: Juliana Barros, Ana Tereza Galvanese, Renata Mecca, Naiada Dubard. Aos colegas da FEF/Unicamp e à Profa. Sílvia, pela acolhida e discussões.

Ao Programa de Aperfeiçoamento de Ensino (PAE) da Faculdade de Medicina da USP, pelo apoio financeiro.

À Gerência de Políticas Públicas para Pessoas com Deficiência (GPPPD) de Ribeirão Pires, pelo acesso às informações e autorização para realização desta pesquisa.

À Elizane Mecena pelas idéias brilhantes, por colocá-las em prática e por "botar pilha" nas boas idéias dos outros; pelo colo, incentivo e discussões acaloradas; pela vivacidade com que conduz suas práticas.

À Tânia e Alessandra pela constante disponibilidade no auxílio da coleta de dados. À Paula e Waldir, além do descrito anteriormente, pela luta todos os dias. 
A todos os que fizeram o Projeto Andanças “andar com as próprias pernas" e aos que compuseram a Equipe de Apoio nos diversos momentos. Em especial ao Rui e Laurindo pelas idéias iniciais; ao Chicão e Renildes que, na mais pura simplicidade, me contaminaram com a emoção do trabalho.

Aos participantes do Projeto Andanças que, com a sua alegria, chamaram a atenção desta pesquisadora e despertaram o desejo de mergulhar nesta experiência; pela acolhida nos passeios e disponibilidade para entrevistas e conversas.

Aos amigos do Centro de Apoio à Inclusão Escolar Ricardo Tolesano Mendes que auxiliaram o manejo do tempo, necessário na construção inicial deste trabalho: Gislene, Yolanda, Clayton, Talitinha, Eduardo, Beth, Sônia, Lúcia Adriana, Tati, Kika, Jane, Madalena, Kelly, Bel, Laura, Luciane, Flávia, Zé Nilton, Camila. Em especial à Gisa pela companhia tão afetiva; à Déa e à Renatinha pelas ricas construções.

À equipe do CAPS Infanto-Juvenil Recriar, por compreender as ausências e possibilitar a abertura de espaços para a realização desta pesquisa, cuidando do outro espaço de trabalho. Segurando "as pontas" sempre: Monique, Fernanda, Régis, Joelma, Gorete, Inês, Renata, Aline, Cris Stoever, Rogério, Rebeka, Ilza, Wilma, Flávia, Evelin, Carol, Milena e Mery. À Márcia, por toda a compreensão; Kelly, pela escuta e incentivos; Priscylla, Paulo, Andréa, Adriana e Patrícia, pelas discussões e idéias na construção afetiva dos trabalhos e pelas incríveis parcerias.

À Fábia Ceci, Edilaine Marinheiro, Kelly Kanazawa e Monique, pelas transcrições das entrevistas.

À Cida, pelo trato cuidadoso dessa escritura.

À Renata Tavares, pelos cuidados finais. 
Ao Bruno Gomes, pelo testemunho e cuidado deste e outros processos.

Ao EncontrAR-TE e seus participantes, de certa forma, embrião deste trabalho.

Às queridas Mari Dotti, Taís Koike e Gi Asanuma pelo EncontrAR-TE, pela Amizade, pelos encontros intensos e vivos que produzem novos olhares para a vida.

À Gi e Ana Marx pelo, suporte e pelas trocas. Ana, obrigada pelo resumo e por terminar antes. Gi, agradeço por me acompanhar sempre com sua escuta tão acolhedora!

Aos amigos que testemunharam e acompanharam esse processo, incentivando e acolhendo a experiência. À Bel, pela companhia sempre afetiva, mesmo que distante. À Simonete, pela disponibilidade e, claro, pelas risadas. À Naiada, pela força e incentivo.

À família Saito que está sempre presente nos momentos difíceis. Ao meu pai Mitsuo, com quem aprendi o silêncio afetuoso. À minha mãe Teresa, com quem aprendi uma certa ousadia e atrevimento. À tia Yoshiko, tio Massami e Emília, a quem sempre agradecerei pelos cuidados em momentos que foram tão delicados.

Ao tio Constante (in memorian) e à Victória por tanto carinho, preocupação e cuidados.

Ao Carlos, o maior companheiro dessa vida; por estar sempre ao meu lado; por compreender as ausências, sustentar as difíceis escolhas e acompanhar todas as angústias desse processo; pelo Amor vivido e construído todos os dias, nas diferenças de cada um de nós, que nos fortalece e impulsiona a continuar. 
"É uma somatória disso tudo, na verdade, é uma tessitura. É uma tessitura disso tudo, não é nem somatória, é uma tessitura. Quando você pega um tecido, você não consegue enxergar muito bem as tramas, você tem que aproximar muito, olhar, tentar abrir, pra ver por onde passa o fio, por onde passa o outro fio, se é de uma cor só, se tem outra, onde eles se encontram. Então é um pouco disso: é ter acesso ao lazer, é empoderar, é tirar de casa,é mostrar que o mundo é grande, é dizer que ele pode estar perto do artista, além da televisão, é dizer pra ele "olha, tem o desejo de sair", então é dizer que ter cultura é legal num país que não dá cultura pra ninguém, só para um pequeno grupo, então acho que na verdade é uma tessitura de muitos elementos e que foi assertivo."

EHM, 2009 


\section{SUMÁRIO}

Listas de Tabelas, Fotos, Figuras, Gráficos e Quadros

Resumo

SuMMARY

$\begin{array}{ll}1 \text { INTRODUÇãO } & 01\end{array}$

$\begin{array}{ll}\text { 1.1 As PESSOAS COM DEFICIÊNCIA NO BRASIL } & 08\end{array}$

1.2 A PARTICIPAÇÃO SOCIAL DAS PESSOAS COM DEFICIÊNCIA 09

$\begin{array}{ll}1.3 \text { Oвjetivos } & 15\end{array}$

1.3.1 Objetivos Gerais

$\begin{array}{ll}\text { 1.3.2 Овjetivos Específicos } & 15\end{array}$

2 Percursos Teóricos 16

$\begin{array}{ll}\text { 2.1 Sobre Lazer } & 17\end{array}$

2.1.1 TEMPO LIVRE E TEMPO DE TRABALHO: TEMPORALIDADES ENTRELAÇADAS 18

2.1.2 Por um CONCeito de Lazer... 22

2.1.3 Traços da história: as Produções Sobre lazer no Brasil 26

2.2 Interfaces: Questões sobre Lazer, Saúde E Terapia Ocupacional 32

2.2.1 Relações sobre Lazer e Saúde 33

2.2.2 Lazer e Terapia Ocupacional: alguns pontos de contato 38

2.2.3 O Lazer enquanto Ação Humana 47

2.3 Notas preliminares sobre Participação Social e Alteridade 51

2.3.1 Sobre Participação Social 51

2.3.2 Atualizando CONCeitos E CRIANdo PASSAGENS: DE UMA SOCiedade INCLUSIVA PARA UMA SOCIEDADE DA DIFERENÇA

2.3.3 Alteridade: A DIFERENÇA COMO SINGULARIDADE E SIMILARIDADE DO SER HUMANO 59

2.3.4 Questões sobre diferenças: Alteridade e Identidade 60

2.3.5 SingUlaridADE E SIMILARIDADE: CONEXÕES ROMPIDAS PELA VELOCIDADE 66

2.3.6 OS HOMENS EM RELAÇÃO: A ALTERIDADE EMERGE NO ENCONTRO 69

3 Percursos Metodológicos 72

3.1 O CAMINHO DO PENSAMENTO 
3.2.1 Observação Participante 76

3.2.2 Diário de CAmpo $\quad 79$

3.2.3 Estudo de documentos dos Registros do Projeto AndançAS 80

3.2.4 ENTREVISTA SEMIESTRUTURADA COM INFORMANTES-CHAVE 82

3.2.4.1 Seleção dos informantes-chave

$\begin{array}{ll}3.3 \text { Procedimentos Éticos } & 90\end{array}$

3.4 Análise dos dados Qualitativos $\quad 91$

3.4.1 OS PROCEDIMENTOS DE ANÁlISE 94

4 CaracterizaÇão do CAMPo de PESQUisa 96

4.1 Estudo de caso do Projeto Andanças - Incluir para mudar o olhar 97

4.1.1 O Município de Ribeirão Pires 98

4.1.2 A população com deficiência e o Município de Ribeirão Pires 99

4.1.3 Um nOVo OlHar POlítico PARA A QUeSTÃo DA DEFICIÊNCIA: a GPPPD 100

$\begin{array}{ll}\text { 4.1.4 LOCAIS DE DESENVOLVIMENTO DA PESQUISA } & 108\end{array}$

$\begin{array}{ll}4.2 \text { O Projeto Andanças - Incluir para mudar o olhar } & 109\end{array}$

$\begin{array}{ll}\text { 4.2.1 Os Participantes } & 111\end{array}$

$\begin{array}{ll}\text { 4.2.2 A Equipe de Apoio } & 115\end{array}$

$\begin{array}{ll}\text { 4.2.3 Os Passeios } & 126\end{array}$

$\begin{array}{lr}\text { 4.2.4 Possibilidades e Participações } & 130\end{array}$

5 AnÁlise E Discussão: os Dados da EXPERIÊNCIA 132

$\begin{array}{ll}5.1 \text { Participação Social } & 133\end{array}$

5.2 EnVolvimento afetivo e Subjetivo 155

$\begin{array}{ll}5.3 \text { Alteridade } & 160\end{array}$

5.4 Conhecimento TÁcito: Relatos Que CaPtam gestos 169

5.5 O LAZER: DENOMINAÇÃO QUE EMERGE NO CONTATO DO PESQUISADOR COM $\begin{array}{ll}\text { O OBJETO DE PESQUISA } & 173\end{array}$

$\begin{array}{lr}6 \text { ConsideraÇões Finais } & 177\end{array}$

$\begin{array}{lr}\text { Anexos } & 182\end{array}$

$\begin{array}{ll}\text { REFERÊNCIAS } & 197\end{array}$ 


\section{LiSTAS DE TABELAS}

Tabela 1 - Locais visitados pelo Projeto Andanças e número de visitas por ano no período de 2006 a 2008

Tabela 2 - Participantes que realizaram dez ou mais passeios com o Projeto Andanças no período de 2006 a 2008

Tabela 3 - Participação da Equipe de Apoio em cada um dos passeios realizados em 2006

Tabela 4 - Participação da Equipe de Apoio em cada um dos passeios realizados em 2007

Tabela 5 - Participação da Equipe de Apoio em cada um dos passeios realizados em 2008

Tabela 6 - Descrição dos passeios realizados em 2006 pelo Projeto Andanças

Tabela 7- Descrição dos passeios realizados em 2006 pelo Projeto Andanças

Tabela 8- Descrição dos passeios realizados em 2006 pelo Projeto Andanças 


\section{LiSTA DE FOTOS}

Foto 1 - Tour em Santos - Participantes do Projeto Andanças. Passeio na cidade, em 2006.

Foto 2 - Tour em Santos - Participante do Projeto Andanças é carregada pela acompanhante Equipe de Apoio. Passeio na cidade, em 2006.

Foto 3 - Tour em Santos - Participante do Projeto Andanças recebe auxílio da acompanhante para subir as escadas. Passeio na cidade, em 2006.

Foto 4 - Tour em Santos - Participantes do Projeto Andanças em passeio na cidade, em 2006.

Foto 5 - Participantes do Projeto Andanças no SESC Interlagos, show de Zélia Duncan, em 2008.

Foto 6 - Imagem de passeio para Casa do Papai Noel (Banco Real), em 2006.

Foto 7 - Participante do Projeto Andanças durante passeio ao Centro Cultural São Paulo (CCSP), em 2007, no show do Chico César. Participante deficiente visual conhece o artista através do tato.

Foto 8 - Participantes e Equipe de Apoio do Projeto Andanças durante passeio ao Parque do Ibirapuera.

Foto 9 - Participantes do Projeto Andanças observando o pouso de helicóptero na Base do Exército de Taubaté, passeio em 2009.

Foto 10 - Participante e Equipe de Apoio do Projeto Andanças em passeio a Base do Exército de Taubaté em 2009.

Foto 11 - Imagem do passeio de Jeep realizado em 2007: Participante sendo colocado no veículo.

Foto 12 - Imagem do passeio de Jeep, realizado em 2008, momento em que muitos participantes já estavam na trilha e outros ainda eram colocados dentro do jipe.

Foto 13 - Imagem do passeio de Jeep, 2007, na trilha realizada. Ao fundo, observa-se uma equipe de auxiliares de enfermagem a postos, no caso de qualquer emergência.

Foto 14 - Cadeira de participante do Projeto Andanças durante o passeio à Praia Grande, em 2006. 
Foto 15 - Imagem de passeio ao SESC Interlagos, em 2006. Integrante da Equipe de Apoio escorrega junto com o participante, favorecendo equilíbrio e segurança à criança.

Foto 16 - Participantes do Projeto Andanças em passeio ao Parque do Ibirapuera, em 2006.

Foto 17 - Participantes e Equipe de Apoio do Projeto Andanças em passeio ao Parque do Ibirapuera, em 2006.

Foto 18 - Participante do Projeto Andanças é orientado por militar da Base do Exército de Taubaté, em passeio realizado em 2009.

Foto 19 - Imagem do passeio realizado para o SESC Interlagos em 2006.

Foto 20 - Cadeira de participante do Projeto Andanças durante o passeio à Praia Grande, em 2006.

Foto 21 - Exposição Ilusão de Verdade. Participantes do Projeto Andanças em visita ao SESC Pompéia, em 2006.

Foto 22 - Participantes do Projeto Andanças observando o pouso de helicóptero na Base do Exército de Taubaté, passeio em 2009.

Foto 23 - Participantes do Projeto Andanças no SESC Santo André, show de Zeca Baleiro, em 2006.

Foto 24 - Exposição Volpi: A Música da Dor - Participantes do Projeto Andanças em passeio ao Museu de Arte Moderna de São Paulo, em 2006.

Foto 25 - Tour em Santos. Participante do Projeto Andanças em passeio ao Aquário de Santos, em 2006.

Foto 26 - Participantes do Projeto Andanças no SESC Interlagos, show de Zélia Duncan, em 2006. 


\section{Lista DE Figuras}

Figura 1 - Mapa do Estado de São Paulo, com destaque para a região do Grande ABC 99

Figura 2 - Capa de talão da campanha do Programa Respeite Essa Vaga.

Figura 3 - Talão de campanha do Programa Respeite Essa Vaga.

Figura 4 - Estampa da camiseta do 4o Passeio do Jeep Club para Pessoas com dEficiência. 


\section{Lista DE GRÁFICOS}

Gráfico 1 - Participantes do Projeto Andanças distribuídos por idade

Gráfico 2 - Participantes do Projeto Andanças distribuídos por sexo

Gráfico 3 - Relação entre Apoios, Participantes e Acompanhantes nos passeios realizados em 2006

Gráfico 4 - Relação entre Apoios, Participantes e Acompanhantes nos passeios realizados em 2007

Gráfico 5 - Relação entre Apoios, Participantes e Acompanhantes nos passeios realizados em 2008

\section{Lista DE QuAdros}

Quadro 1 - Modelo de lista de participantes do Projeto Andanças 


\section{RESUMO}

Saito, CM. Atividades de Lazer: tessitura de espaços para alteridade [dissertação]. São Paulo: Faculdade de Medicina da Universidade de São Paulo, 2010. 217p.

As estratégias de intervenção para a participação social das pessoas com deficiência, no Brasil, estão, de forma geral, ligadas a ações e serviços de saúde ou programas especializados nesta população. Identifica-se o desenvolvimento do campo da Terapia Ocupacional e da Reabilitação como áreas de atuação técnicasespecializadas detentoras de um saber específico, o que reforça o olhar de segregação da sociedade para estas pessoas. A presente pesquisa tem como objetivo problematizar o campo do Lazer, em seu caráter interdisciplinar, como área fundamental de intervenção para favorecer a ampliação da participação social das pessoas com deficiência. O estudo de um grupo de passeio para pessoas com deficiência, o Projeto Andanças, do município de Ribeirão Pires (SP/Brasil), política pública criada a partir do desejo de ver essa população nos diversos espaços sociais, permitiu uma análise e reflexão sobre estas questões. Para este estudo propôs-se uma pesquisa qualitativa, com a realização de um estudo de caso, utilizando-se os seguintes procedimentos: pesquisa bibliográfica; observação participante; Diário de Campo; estudo documental e entrevista com informantes-chave. Os resultados afirmam o campo do Lazer como área de intervenção interdisciplinar fundamental para a construção de uma sociedade aberta às diferenças subjetivas. O conceito de lazer foi compreendido, aqui, como constituinte de um processo para a ampliação da participação social e diz respeito à própria produção da vida. A construção de uma sociedade inclusiva necessita de ações que possibilitem o contato com a diversidade da existência humana no cotidiano, colocando as pessoas em experiência de alteridade, possibilitadas espontaneamente pela vivência do lazer. A discussão da participação social dessas populações a partir de atividades de lazer e os seus desdobramentos ainda são pouco estudados. O presente trabalho aponta para a necessidade de pesquisas que enfoquem as intervenções que abordem as barreiras de atitude, trazendo uma nova luz às práticas e estudos sobre o lazer, voltados para as populações com deficiência.

Descritores: participação comunitária; atividades de lazer; alteridade; pessoas com deficiência 


\section{SUMMARY}

Saito CM. Leisure Activities: weaving spaces for alterity [dissertation]. São Paulo: Medical School, University of São Paulo; 2010. 217p.

The intervention strategies to improve social participation of people with disability in Brazil are, in general, linked to actions and health services or specialized programs for this population. Occupational Therapy and Rehabilitation fields are identified as such areas of technical-specialized performance with specific knowledge, which strengthen the view of social segregation for all those people. This research intended to discuss the Leisure field, as a fundamental area of intervention, implied an interdisciplinary nature, to increase social participation of people with disability. A case study of Projeto Andanças - incluir para mudar o olhar, a tour group for people with disability, developed in Ribeirão Pires, a city located in the metropolitan area of São Paulo (Brazil) was done. It is a public policy created from the desire to see those people in the diverse social spaces. A qualitative research was proposed and developed through Bibliographical Research, Participant Observation, Field work, Documental Study and Interview with key Informants. The results affirmed the Leisure field as a fundamental interdisciplinary intervention area to build a society that accepts the subjective diversity. The concept of leisure was understood as part of the process to increase social participation. It also reflected the production of life. Building an inclusive society needs actions that allow the contact with the human being diversity in daily life, enabling people to have an experience of otherness. Leisure, with its spontaneous nature, favors those contacts and affections. The discussion about social participation of those populations in leisure activities and its consequences are barely studied. This research presents the need to develop new studies about attitudes barriers, which brings another view to Leisure studies for people with disability.

DESCRIPTORS: consumer participation; leisure activities; alterity; disabled persons. 


\section{INTRODUÇÃO}

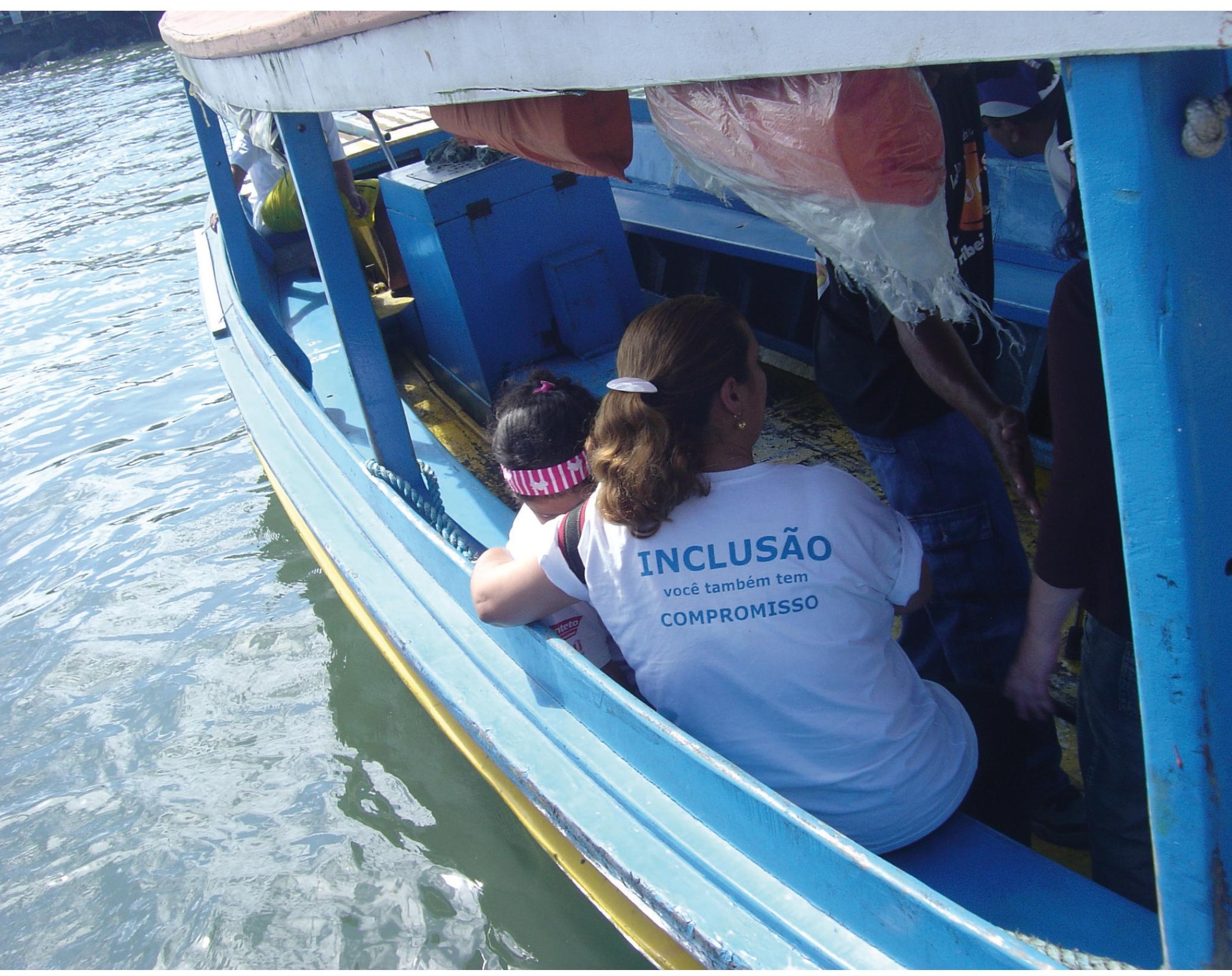

Foto 1 - Tour em Santos - Participantes do Projeto Andanças. Passeio na cidade, em 2006. 
A construção desta Pesquisa trilhou um percurso que realiza um diálogo entre os campos do Lazer e da Terapia Ocupacional, para discutir a participação social de pessoas com deficiência. Não se trata, aqui, de estudar práticas específicas da Terapia Ocupacional. Entretanto, os conhecimentos deste campo constituíram pontos de articulação fundamentais para a discussão que se apresenta: é a partir da formação e da experiência profissional do pesquisador nesta área que as questões para formulação do Projeto de Pesquisa são configuradas.

Os estudos sobre deficiência (Desability Studies) constituem uma área relativamente nova e, apesar de agregar conhecimento de áreas diversificadas, como a Antropologia, a Sociologia, as Ciências Sociais, a Psicologia e a Medicina, ainda prevalece o enfoque orgânico e biológico (Pereira, 2006).

O encontro com o Projeto Andanças - incluir para mudar, desenvolvido na cidade de Ribeirão Pires (São Paulo-SP), convidou a refletir sobre as práticas sociais voltadas para a participação das populações com deficiência. Trata-se de levar essas pessoas para passear.

Passear, segundo Kujawski (1991), é uma forma de estar efetivamente na cidade, apropriar-se dela a partir das condições e possibilidades do sujeito. Ao passear, observamos cena por cena, o aqui e o acolá; os espaços passam a ter um valor e um significado singular e assim ganhamos nossa identidade, a partir do contorno que a cidade nos dá. (Kujawski apud Aoki, 2009, p. 145)

Um dos motivos que nos levaram a realizar esta pesquisa foi o encantamento proporcionado pelo Projeto, diante da ideia simples ${ }^{1}$ e de sua dimensão

\footnotetext{
${ }^{1}$ Oury (2009), em sua passagem pelo Brasil, discorre sobre as diferenças entre o simples e o simplista durante palestra proferida em ocasião do lançamento de seu livro "O Coletivo". Para se ter algo simples, é necessária a complexidade. Ele dá como exemplo o simples ato de andar que, se olhado profundamente em suas estruturas neurofisiológicas, implica uma complexidade no seu funcionamento. As coisas simplistas não envolvem qualquer complexidade, remetendo à noção de fragmentação e independência dos fatores relacionados.
} 
enquanto política pública municipal e sua abrangência populacional (pessoas com deficiência residentes no Município). Foi possível observar uma complexidade implícita nas experiências instauradas pelo Andanças, que, entretanto, encontrava muitas limitações para formulá-las e transmiti-las. Sentimento vivido por Kinoshita (2001) e expresso no seguinte trecho:

[...] Temos a impressão de que tudo é muito complicado para se teorizar, embora a experiência prática muitas vezes nos leve a pensar que estamos trabalhando com idéias por demais triviais. E essa aparente contradição tem sido difícil de superar. Se tudo é tão trivial, qual é a dificuldade para se explicar essas experiências? (p. 86)

Dessa forma, surge o interesse para elaboração de um estudo sobre o Projeto Andanças. A partir de um contato que possibilitou emergir uma intensa curiosidade e desejo de desvendá-lo; descobrir, trazer às palavras as tramas que o constituem; e o exercício de explicar e teorizar a experiência, mesmo diante da trivial ideia que a norteia.

O percurso teórico apresentado foi construído de forma empírica: era necessário que as palavras, os termos, os conceitos expressassem a experiência. Nesse sentido, os estudos sobre Lazer trouxeram contribuições fundamentais para problematizar o Projeto Andanças, como vivência que favorece uma mudança de olhar da e para as pessoas com deficiência, e que abre possibilidades para que estes diferentes modos de ser circulem nos espaços sociais. Este pensamento foi desenvolvido a partir de uma interlocução com os campos da Saúde e da Terapia Ocupacional, sem, entretanto, fixá-lo a estas áreas. Pensamento que percorre espaços diferentes, convidando para uma compo- 
sição interdisciplinar, deslocando o marcador biológico para as questões da deficiência e construindo um olhar para a participação. Outro caminho que contribuiu para sustentar as elucubrações propostas foi abordar a participação social em sua 'molecularidade' (Rolnik, 2008), nos microaspectos que a descrevem como conceito, abrindo a possibilidade de explorar o tema da alteridade como experiência para a qual é necessário um olhar atento, vagaroso o suficiente, para que ela possa se processar.

Após o itinerário trilhado para dizer da experiência, são apresentados os meios de aproximação e de mergulho no objeto de estudo com o "Percurso Metodológico". O leitor, então, é convidado a submergir nessa experiência, através dos dados apresentados no "Estudo de Caso", para, em seguida, acompanhar os discursos dos atores envolvidos neste processo. Às falas apresentadas são acrescida o olhar, as experiências e pensamentos gerados no pesquisador. Ao final desta trajetória, novas inquietações se colocam como potência que o Projeto Andanças, em sua forma simples, tem de gerar questionamentos, de mobilizar outros pensamentos. Espera-se, assim, que esta leitura possa suscitar questões e movimentos que ressoem na experiência do leitor, e que possa ampliar para a população com deficiência novas oportunidades de vida e de participação social. 


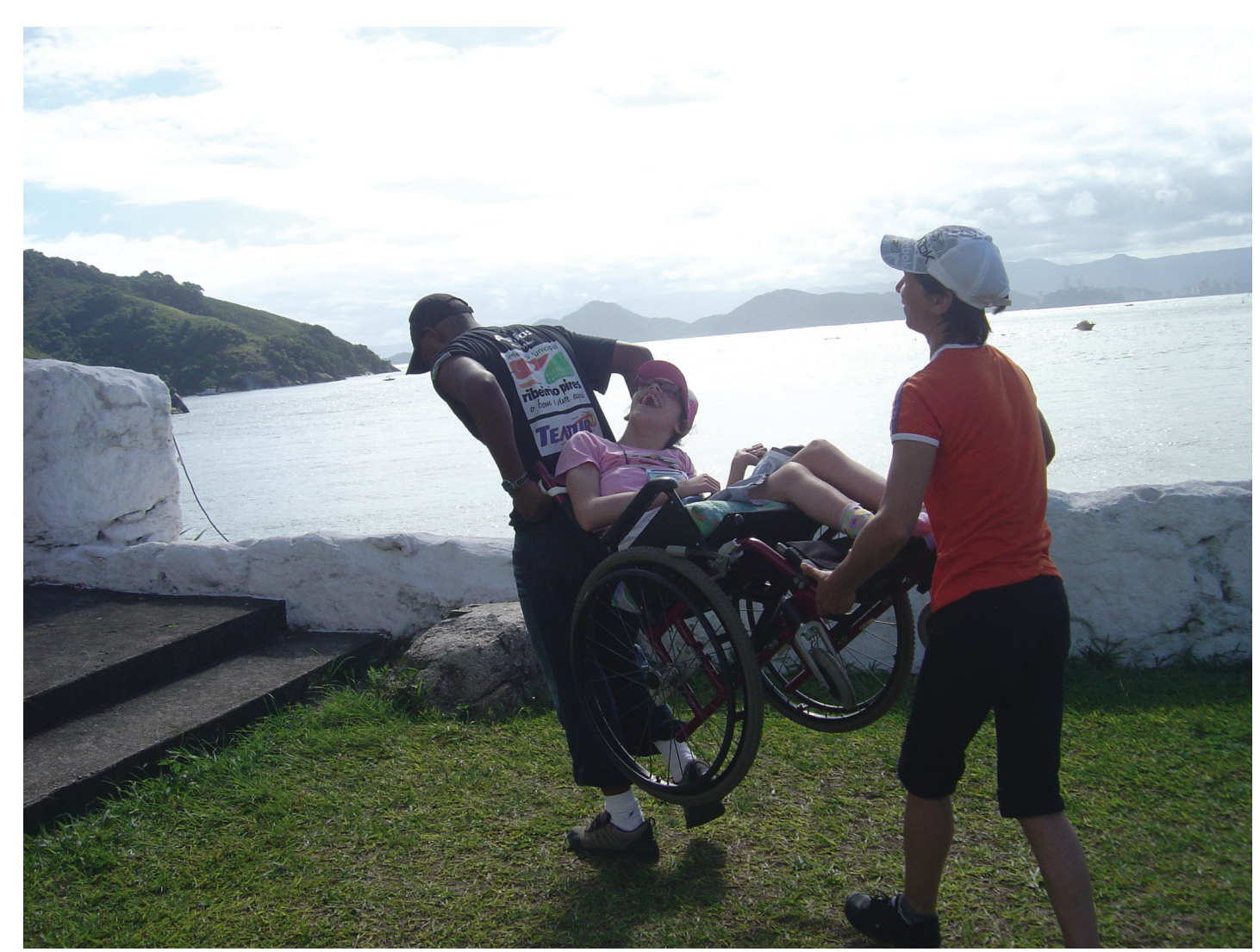

Foto 2 - Tour em Santos - Participante do Projeto Andanças é carregada pela acompanhante Equipe de Apoio. Passeio na cidade, em 2006.

A prática da inclusão social vem aos poucos substituindo a prática da integração social e parte do princípio de que, para inserir todas as pessoas, a sociedade deve ser modificada de modo a atender às necessidades de todos os seus membros: uma sociedade inclusiva não admite preconceitos, discriminações, barreiras sociais, culturais e pessoais.

Nesse sentido, a inclusão social das pessoas portadoras de deficiências significa possibilitar a elas, respeitando as necessidades próprias da sua condição, o acesso aos serviços públicos, aos bens culturais e aos produtos decorrentes do avanço social, político, econômico e tecnológico da sociedade. (Brasil, 2008, p.9)

A questão da inclusão e participação social de pessoas com deficiência e/ou transtornos psiquiátricos é, cada vez mais, discutida nos diversos setores 
sociais. As situações históricas de reclusão e confinamento dessas populações foram revistas e modificadas de acordo com o tipo de sensibilidade social predominante em relação a esses sujeitos.

Nos séculos XVII e início do XVIII, o olhar de incapacidade para o trabalho sobre essas populações, acrescida à ideia de suposta periculosidade dos loucos, justificou recolhê-los para casas de internamento juntamente com velhos, mendigos, doentes e crianças. Em meados do século XVIII, tais instituições começaram a ser apontadas como erros econômicos, à medida que o mercado de trabalho passa a valorizar a mão de obra dos pobres, com o processo de Revolução Industrial. Com o fechamento dos locais de internamento, os loucos e deficientes são separados das outras populações com as quais eram confinadas, demandando outras medidas de atenção (Nicácio e Mângia, 2001).

Na configuração dos campos da Reabilitação Física e da Saúde Mental, desenvolveu-se um vasto corpo de conhecimento técnoespecializado, mantendo, entretanto, suas respectivas populações (deficientes e loucos), ainda, segregadas. O confinamento é então localizado, inscrito na grande área da Saúde, à qual pertencem os conhecimentos sobre tais populações e as formas de intervenção específicas. Estas inscrições possibilitaram a tais populações o estabelecimento de uma relação social de tutela: são vistos como sujeitos incapazes de assumir o contrato social, devendo ser assistidos, ficando, assim, muitas vezes, a cargo da filantropia (Nicácio e Mângia, 2001; Oliver e Almeida, 2001).

Os questionamentos e discussões sobre os modelos assistenciais, tanto da Reabilitação Física quanto da Saúde Mental, na década de 1960, caminha- 
ram no sentido de responsabilizar outros setores sociais, além da Saúde, pela atenção a essas populações, expressão visualizada nos processos de desinstitucionalização e nas discussões internacionais sobre alternativas às instituições especializadas e sobre a ampliação da cobertura assistencial em reabilitação (Oliver e Almeida, 2001).

Nesse processo, Puhlmann (2008) afirma que, no Brasil, a atenção às pessoas com deficiência sofreu mudanças significativas. Se, inicialmente, restringiam o protagonismo e a autonomia das pessoas com deficiência, constroem-se, cada vez mais, intervenções que deixam a ideia de "fazer para" e instituem um pensamento de "fazer com" elas. Assim, possibilitam a ampliação da participação social, convidando as pessoas com e sem deficiência a "fazer juntos".

"Fazer juntos" implica desmanchar a ideia de que a pessoa com deficiência se encontra fora da sociedade e é necessário construir práticas para incluí-la. "Fazer juntos" sugere convidar essa população a participar, cada vez mais, dos diversos espaços sociais coletivos, à medida que, como parte da sociedade, se encontram em situação de vulnerabilidade social, decorrente da situação de desvantagem social em que vivem.

As discussões sobre a participação social das pessoas com deficiência, nos diversos campos, e a mudança do olhar para essa população culminaram na formulação de diversos instrumentos legais que regulamentam e normatizam as práticas sociais, de forma que o envolvimento dessas pessoas não seja prejudicado. Apesar dos inúmeros avanços técnicos, é possível observar que as ações de segregação ainda são observadas e parecem, na maioria das vezes, relacionadas à atitude das pessoas em relação à deficiência. 
Lima e Silva (2008) consideram que as barreiras de atitude alicerçam outras e acreditam que a sua identificação é essencial para erradicá-las ou, ao menos, reduzir os processos de exclusão. Essas barreiras ganham materialidade na atitude das pessoas e, dessa forma, muitas vezes não é possível explicitálas. Os autores consideram que as práticas que favorecem a participação das populações com deficiência na escola (e, aqui, se amplia para as práticas sociais de maneira geral), devem envolver pessoas com e sem deficiência como seres atuantes.

\section{As Pessoas Com Deficiência No Brasil}

Dos 500 milhões de pessoas com deficiência no mundo, $80 \%$ vivem em países periféricos. Até a última década do século XX, segundo a Política Nacional de Saúde da Pessoa Portadora de Deficiência, não havia dados oficiais sobre as populações com deficiência no Brasil. Dessa forma, as propostas e estudos tomavam a estimativa da Organização Mundial da Saúde (OMS) como referência, considerando que $10 \%$ da população de um país possuem algum tipo de deficiência (Brasil, 2008)

O Censo de 2000 (IBGE, 2000) instaura um marco conceitual em relação a essa população, com a adoção de um conceito ampliado de deficiência, atribuindo a denominação de pessoas com deficiência àquelas que se consideram incapazes e, também, “àquelas que reportaram possuir alguma ou grande dificuldade permanente de enxergar, ouvir e caminhar". A avaliação das capacidades neste levantamento foi realizada pelo próprio sujeito entrevista- 
do: inclui a percepção que as pessoas têm em relação às mudanças provocadas pela deficiência, quanto às ações, comportamento e participação social. Foram identificados 14,5\% da população brasileira portando alguma deficiência, o que corresponde a 24,5 milhões de pessoas (Neri et al., 2003, p.5; Brasil, 2008).

\subsection{A Participação Social Das Pessoas Com Deficiência}

Apesar de procurar incorporar os direitos das pessoas portadoras de deficiência aos textos constitucionais, a União, os estados e os municípios pouco tem garantido de fato benefícios às pessoas com deficiência. O que se observa na prática são ações isoladas da sociedade civil organizada, representada pelas organização de e para portadores de deficiência. (Neri et al., 2003, p. 132)

O crescente número de discussões realizadas nos diversos setores sociais, sobre as pessoas com deficiência, possibilitou uma mudança de olhar e a reformulação de conceitos em relação a essa população. É na década de 1960 que tem início a construção de uma concepção de deficiência que reflete uma relação entre limitações do deficiente, o ambiente e a atitude social das outras pessoas (Brasil, 2008). Desde então, é possível citar alguns marcos de abrangência internacional no percurso do olhar sobre as pessoas com deficiência:

- A instituição do Ano Internacional da Pessoa Deficiente, em 1981, pela Organização das Nações Unidas (ONU);

- A aprovação do Programa de Ação Mundial para Pessoas com Deficiência, em Assembleia Geral da ONU em 1982, com o objetivo de “promover medidas eficazes para a prevenção da deficiência e para a re- 
abilitação e a realização dos objetivos de 'igualdade' e 'participação plena' das pessoas deficientes na vida social e no desenvolvimento" (ONU, 1982);

- As Normas sobre a Equiparação de Oportunidades para Pessoas com Deficiência, adotadas pela Assembleia Geral da Organização das Nações Unidas, em 1993;

- A Declaração de Salamanca, de 1994, documento que se baseia no princípio da inclusão, defendendo a proposta de escolas inclusivas;

- A promulgação da Convenção Interamericana para Eliminação de todas as Formas de Discriminação Contra as Pessoas Portadoras de Deficiência, através do decreto 3956/01 pela Organização dos Estados Americanos (OEA), em 2001.

Concomitantemente às discussões sociopolíticas sobre a participação social das pessoas com deficiência, a Organização Mundial de Saúde (OMS) inicia uma sistematização no interior de sua "família" de classificações da referida população: a Classificação Internacional de Deficiências, Incapacidade e Desvantagem, (CIDID) em 1998. Esta surge, inicialmente, para descrever e padronizar a restrição funcional ${ }^{2}$ determinada pelas doenças, possibilitando o registro e organização de informações sobre os diferentes estados de saúde (Battistella e Brito, 2002).

A reapresentação da CIDID em 1997, como Classificação Internacional das Deficiências, Atividade e Participação: um manual da dimensão das incapacidades e das limitações (CIDDM-II); e em 2001, em sua versão final, como Classificação Internacional da Funcionalidade, Incapacidade e Saúde (CIF), carre-

${ }^{2} \mathrm{O}$ termo restrição funcional diz respeito às funções do corpo na interação com o meio ambiente e a participação social do sujeito que será classificado. 
gam a evolução conceitual e a construção de um novo olhar para a população de pessoas com deficiência, assim como um novo dimensionamento sobre os conceitos de saúde e de doença. O percurso conceitual iniciado com a CIDID possibilitou a construção da CIF. Esta amplia e positiva as experiências pessoais, registrando a potencialidade e medindo a capacidade dos sujeitos com deficiência, em superar as dificuldades da vida cotidiana. O termo funcionalidade passa a substituir as ideias de incapacidade, deficiência, invalidez e desvantagem (Battistella e Brito, 2002; Brasil, 2008).

A participação social e a realização de atividades são atributos das diferentes áreas do viver, que apresentam crescente importância na compreensão dos processos saúde-doença. No Modelo de Funcionalidade e Incapacidade, proposto pela OMS e expresso pela CIF, tais características são entendidas como componentes que interferem diretamente nas condições de saúde das pessoas. Portanto, o conceito de reabilitação deve ser ampliado e compreender ações que incluam relações diretas entre equipamentos da saúde, da educação, cultura, lazer e outros, para efetivar o trabalho de recuperar, facilitar ou mesmo favorecer o desempenho e habilidades ${ }^{3}$ da população atendida nas respectivas áreas do viver (OMS, 2003).

Os questionamentos e discussões sobre os modelos assistenciais em Reabilitação, a partir da década de 1960, caminharam para responsabilizar outros setores sociais, além da saúde, pelo cuidado dessas populações, expressão visualizada nos processos de desinstitucionalização e nas discussões internacionais sobre alternativas às instituições especializadas e sobre a ampliação da cobertura assistencial em reabilitação (Oliver e Almeida, 2001).

\footnotetext{
${ }^{3}$ A CIF utiliza o termo desempenho como qualificador que "descreve o que o indivíduo faz no seu ambiente habitual. Como o ambiente habitual inclui um contexto social, o desempenho também pode ser entendido como 'envolvimento em uma situação de vida', ou a 'experiência vivida' das pessoas no contexto real em que vivem"”. Já o termo capacidade "descreve a habilidade de um indivíduo para executar uma tarefa ou ação" (OMS, 2003, p. 25-6).
} 
Até a década de 1980, a perspectiva teórica, que norteava as ações em relação a esta população e a sua participação, referia-se à inserção social, que considerava a participação social como um problema individual: o sujeito se adapta às normas sociais.

Ao saírem do lugar do confinamento e aumentando a participação social, as pessoas com deficiência passam, pouco a pouco, a fazer parte de um cenário social trazendo consigo uma nova compreensão que vai ao encontro do que o assistente social Sassaki (1997, p. 41) denomina como inclusão social - uma via de mão dupla: "a sociedade se adapta para incluir em seus sistemas sociais gerais, pessoas com necessidades especiais e, simultaneamente, estas se preparam para assumir seus papéis na sociedade”.

Sawaia (1999) problematiza o conceito de inclusão, em relação dialética com a ideia de exclusão. Nessa perspectiva, todos estão inseridos, de algum modo, na dinâmica social, mesmo que isso ocorra pelos mecanismos de exclusão. "A sociedade exclui para incluir. E não se trata de uma falha no sistema, mas de uma sequência regular e necessária para sua perpetuação nos moldes atuais" (Rocha e Castiglioni, 2005).

A questão da acessibilidade física apresenta-se como um importante elemento que favorece a participação dessas populações, implicando ações da sociedade para facilitar a circulação social das pessoas com deficiência. Neri et al. (2003, p. 130) observa que, em 1989, através da Lei 7.853, foi transferida aos municípios brasileiros a responsabilidade por adotar "normas que eliminem as barreiras de acesso das pessoas portadoras de deficiência a edificações, espaços urbanos e meios de transporte". 
Outro ponto importante para a discussão do acesso à participação são as condições socioeconômicas em que vive essa população. A estimativa de que expressiva parcela de pessoas com deficiência viva em regiões onde não se dispõe de serviços necessários, que as auxiliem a superar limitações, mantendo-as sem direitos básicos, é fundamentada na associação entre deficiência e pobreza. Marinho (2009) relata que estudos estatísticos sobre essa correlação é escassa no Brasil. Considerando que o conceito de pobreza está associado às noções de desigualdade e exclusão social, essas questões juntamente com a deficiência produzem e perpetuam múltiplas vulnerabilidades, reduzindo oportunidades (Cavalcante et al., 2009):

Os deficientes são os mais pobres entre os pobres e permanecerão assim se um conjunto de medidas envolvendo ações em rede, junto às famílias, comunidades, instituições, órgãos governamentais e não-governamentais e programas sociais, não forem acionadas. (2009)

Um passo importante para reduzir a pobreza no Brasil é o Benefício de Prestação Continuada (BPC), que é um benefício da Assistência Social. Este consiste na transferência incondicional e mensal de renda, equivalente a um salário mínimo, destinado às pessoas pobres com deficiência e às idosas acima de 65 anos. Regulamentado através do LOAS (Lei Orgânica de Assistência Social, de 1993), sua eficácia ainda é discutida, pois beneficia apenas famílias com renda per capita inferior a um quarto do salário mínimo, ou seja, que estão abaixo da linha da pobreza. Assim, muitas pessoas com provimentos insuficientes para alcançar condições de vida decentes são privadas do benefício (Marinho, 2009; Santos, 2009). 
Diante desse contexto, ante a complexidade que se instaura para a vida e a construção dos direitos e da inclusão social das pessoas com deficiência, o Lazer constitui mais um campo restrito de participação social das populações com deficiência. Em relação às atividades de Lazer, Martinelli (2008) observa que falta oportunidade de participação nesse campo para as pessoas com deficiência, o que implica uma dificuldade de contatos e de presença em outros contextos sociais. Para a autora, a participação dessas populações em atividades de lazer pode incentivar a sociedade a criar espaços para a convivência na diversidade. É sobre este tema que se faz a problematização do presente campo investigativo; constrói-se aqui uma aproximação que considera a vivência desta população e uma escuta atenta sobre os vários estratos que compõem este aspecto do viver coletivo.

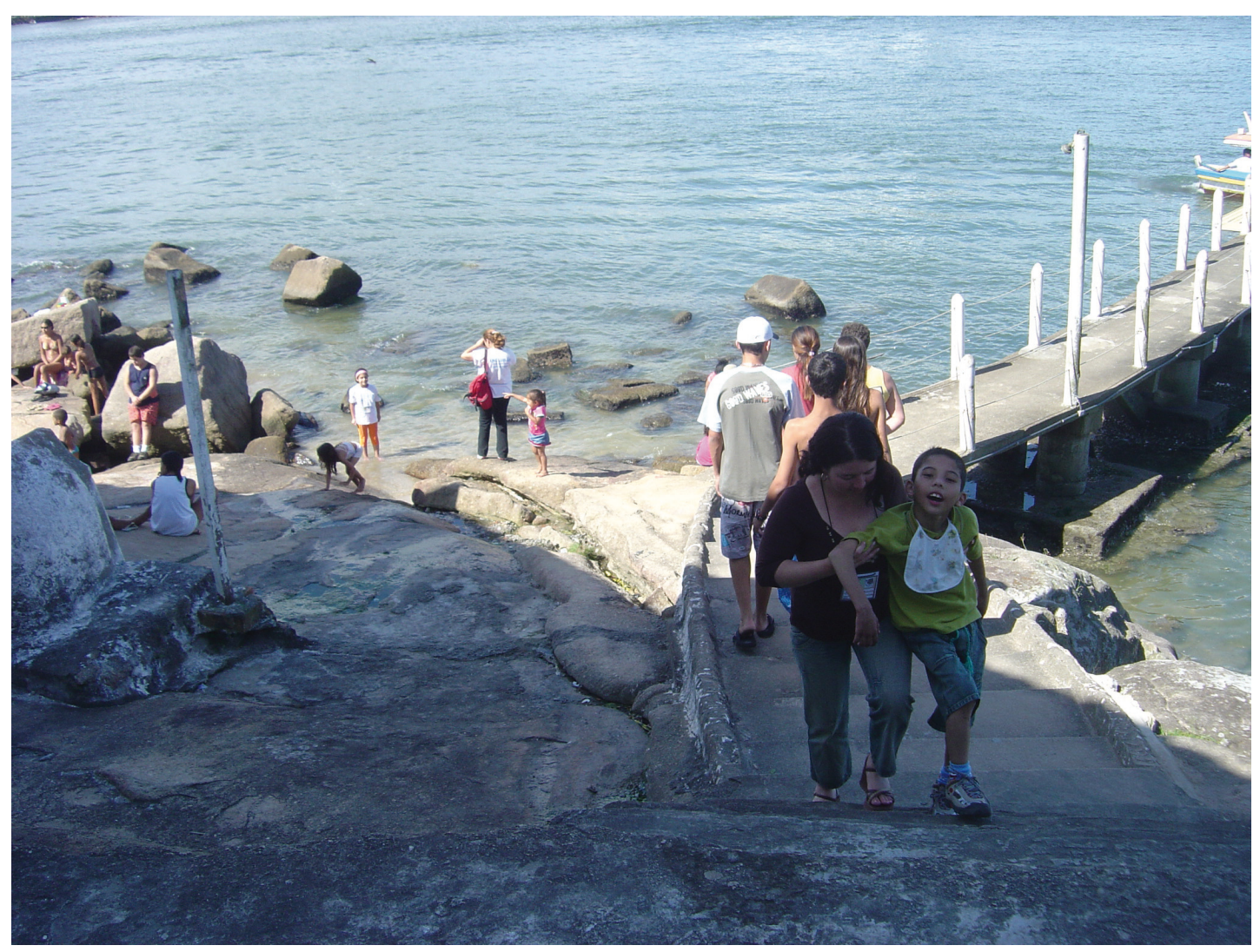

Foto 3 - Tour em Santos - Participante do Projeto Andanças recebe auxílio da acompanhante para subir as escadas. Passeio na cidade, em 2006. 


\subsection{Oвjetivos}

\subsubsection{Objetivo Geral}

Contribuir para a discussão do Lazer como campo fundamental de intervenção para ampliação da participação social das pessoas com deficiência, através do estudo de caso do Projeto Andanças: incluir para mudar o olhar.

\subsection{2 Овjetivos Específicos}

- Refletir sobre as práticas do Projeto Andanças à luz dos estudos do Lazer;

- Identificar e descrever ações do Projeto Andanças que favoreçam a participação social das pessoas com deficiência;

- Identificar e descrever ações do Projeto Andanças que favoreçam a aceitação das populações com deficiência nos diferentes espaços sociais;

- Conhecer alguns dos desdobramentos provocados pelas atividades do Projeto Andanças. 


\section{Percursos TEÓRICOS}

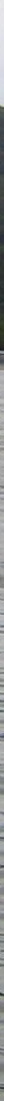

Foto 4 - Tour em Santos - Participantes do Projeto Andanças em passeio na cidade, em 2006. 


\subsection{Sobre LAZER}

O LAZER, muitas vezes, não é levado a sério, assim como as ações que favorecem a sua prática. Elas ainda são vistas por muitas pessoas como atividade de quem não tem o que fazer, um (des)valor construído a partir dos modelos econômicos e sociais de produtividade. Essa informalidade remete ao tempo de lazer uma disponibilidade dos sujeitos para diferentes fazeres e experiências, povoadas por descanso e diversão e onde as trocas sociais se fazem por afinidades e interesses.

O entendimento do lazer como o inverso das obrigações, especialmente do trabalho produtivo, é predominante na sociedade atual. No senso comum imperam visões do lazer como o "não trabalho", tempo livre ou desocupado destinado à diversão, à recuperação de energias, à fuga das tensões cotidianas, como perda de tempo, futilidade, contribuindo para uma valoração preconceituosa acerca do tema (Gomes, 2008).

Paralelamente a esse panorama, nas últimas décadas do século XX, o lazer ocupa espaço cada vez maior no cenário social, seja no Brasil, seja em outros países, com um crescente número de pesquisas, debates, publicações e grupos de estudos, o que evidencia um interesse e a necessidade de aprofundar o tema. O lazer vem sendo considerado "fator básico para o exercício da cidadania plena e para a busca de uma vida com mais sentido e qualidade", sendo previsto como direito social em documentos oficiais, como a Declaração Universal dos Direitos Humanos e a Constituição Federal do Brasil. Além disso, amplia-se a sua compreensão como uma dimensão da cultura, “campo da vida humana decorrente de construções/interações culturais, sociais, políticas, entre outras" (Gomes, 2008, p. 9-11). 
Etimologicamente, a palavra lazer provém do latim, derivando dos termos licere e licet, criados pela antiga civilização romana e significando lícito, permitido, ter o direito, poder. Em sua forma arcaica, lezer, traz consigo a conotação de preguiça, pouca vontade de trabalhar. Atualmente, a partir de uma constituição histórica, o lazer incorpora valores associados ao "não trabalho", assumindo a conotação de ócio, em antítese ao trabalho (Gomes, 2008). Esses valores incorporados historicamente contribuem para determinadas concepções de lazer, que operam no cotidiano das pessoas.

\subsubsection{Tempo Livre e Tempo De Trabalho: Temporalidades Entrelaçadas}

A discussão sobre o tema do lazer, seja ela realizada no âmbito acadêmico ou no senso comum, é geralmente desenvolvida a partir de concepções sobre trabalho. Antunes (2009), em sua obra Os Sentidos do Trabalho, discorre sobre a centralidade da ação humana na categoria trabalho, a partir do pensamento de Lukács (1980). Este aponta o trabalho como uma categoria da ação humana que possibilita uma transição das formas pré-humanas para o ser social, instaurando-se no "centro do processo de humanização do homem" (Antunes, 2009, p.136). Compreendendo trabalho a partir de uma perspectiva marxista, como produção de valores de uso, ele expressa uma relação "metabólica" entre a natureza e o ser social, com a transformação dos objetos naturais em coisas úteis. No decorrer do tempo, as interrelações entre os seres sociais na produção de valores de uso são abrangidas nesta concepção de trabalho. 
Com a instauração de um sistema social gerido pelo capital $^{4}$ as atividades laborativas perdem o sentido para quem trabalha. Ao subordinar o valor de uso das coisas ao valor de troca, o capital opera uma separação entre a produção voltada para a satisfação das necessidades humanas e as necessidades de autorreprodução do próprio capital, introduzindo na dinâmica social elementos fetichizadores e alienantes. Os trabalhadores são, então, personificados como trabalho, além de serem separados e alienados dos meios de produção, que exerce um poder de mando sobre eles (Antunes, 2009).

No mundo contemporâneo, a grande maioria dos trabalhadores atribui um sentido de obrigatoriedade ao trabalho, o que é decorrente da necessidade de gerar valores de troca que possibilitem a manutenção da vida. A partir desta valoração, fica explícita a relação de oposição estabelecida entre o tempo de trabalho e o tempo livre, contribuindo para as concepções preconceituosas de lazer.

A constituição do lazer como uso do tempo livre economicamente útil e moralmente aceito, um estatuto designado para atividades, espaços, equipamentos e atitudes, que implicam o descanso e diversão para o trabalhador, assim como a implementação de valores e normas, é apontada por Sant'anna (1994) como uma tendência nas concepções de lazer. A construção histórica deste conceito implicou uma dissociação de qualquer traço religioso ou lúdico do trabalho, favorecendo a instauração da divisão do tempo de acordo com as distintas práticas sociais: o tempo do trabalho, o tempo do lazer, o tempo do estudo etc. Assim, nos grandes centros

\footnotetext{
${ }^{4}$ Antunes (2009) compreende o sistema de metabolismo social do capital a partir do pensamento de Mészáros (1995), como "o complexo caracterizado pela divisão hierárquica do trabalho, que subordina suas funções vitais ao capital”.
} 
urbanos, o tempo além de dividido é medido, contabilizado, poupado e compartimentalizado, o que foi possibilitado pelo uso de máquinas e instrumentos que permitem a aceleração do "movimento dos corpos no trabalho, em ruas e estradas, de alterar e disparar todo um modo de perceber e vivenciar a realidade" (Sant'anna, 1994, p.14).

As análises sobre o lazer são, em geral, pautadas em categorias diversas (trabalho, cultura, educação, atitude, práxis e outras), sendo a categoria tempo central em todas as análises (Amaral, 2009). A ideia de tempo livre surge com as contradições do desenvolvimento capitalista como conquista de classe. Para Adorno (2002), o tempo livre corresponderia ao que era o ócio: privilégio de uma vida folgada. Entretanto, pode-se identificar grande distinção em relação ao tempo livre. A redução do trabalho à mera atividade de subsistência sob forma de salário, como valor do sistema socioeconômico vigente, e as extensas jornadas de trabalho impulsionaram historicamente a conquista de um tempo fora do trabalho. As várias tentativas de conceituação do tempo livre colocam-no como um tempo restante após o trabalho, as obrigações e necessidades. O ócio, entretanto, é pejorativamente associado à preguiça, vadiagem e inutilidade (Mascarenhas, 2000).

O ócio, assim como o lazer, apresenta-se inserido num quadro de transformações sociais, como produto de condições determinadas. Assim, no decorrer dos tempos, foi ganhando novos e diferentes sentidos, conservando ou abandonando antigas significações, até que sua configuração fosse radicalmente transformada, desdobrando-se no lazer. Este, apresenta uma relação de ruptura e continuidade com o ócio, ora incorporando-o, ora negando-o. O lazer é muitas vezes tratado como negação do ócio, sendo este compreendido 
como erro e sendo colocado sob uma ordem moral, racional e economicamente útil (Mascarenhas, 2005; Sant'Anna, 1994).

Na contemporaneidade, o lazer é a forma de apropriação dominante do tempo livre. Ele expressa determinações econômicas, políticas, culturais e sociais produzidas pelo capitalismo. Do ócio ao lazer, nos diferentes períodos, percebe-se que o lazer mantém estreita relação com as transformações da organização do trabalho (Mascarenhas, 2005).

Diz Adorno (2002, p.102) no texto Tempo Livre: "O tempo livre é acorrentado ao seu oposto" e aponta que ele depende da situação geral da sociedade. Ao escrever este texto em 1969, questiona:

Que ocorre com ele (o tempo livre) com o aumento da produtividade no trabalho, mas persistindo as condições de não-liberdade, isto é, sob relações de produção em que as pessoas nascem inseridas e que, hoje como antes, lhe prescrevem as regras de sua existência? (p. 104)

Já naquela época, Adorno (2002) observava que o tempo livre tendia a uma direção contrária ao seu próprio conceito: apesar de uma perspectiva de liberação do tempo de trabalho, prolongava-se no tempo de não trabalho, uma não-liberdade. A instauração do pensamento de Marx na sociedade burguesa da época, cujos reflexos são ainda observados na contemporaneidade, que colocam a força de trabalho como mercadoria, coisificando-a, institui a vigência de uma moral do trabalho. Assim, o tempo de não trabalho tem como função restaurar a força de trabalho, para que se trabalhe melhor, não devendo sequer lembrar o próprio trabalho. Observam-se, assim, numa dimensão 
coletiva, ocupações do tempo livre esvaziadas de sentido para o sujeito que a realiza, predominando uma dimensão heterocondicionada ${ }^{5}$ sobre uma escolha autocondicionada. O ócio é, então, associado à improdutividade, tem a sua valoração negativa reforçada.

A categoria tempo aparece como fundamental em muitos conceitos e discussões sobre lazer. Mas é importante considerar que as concepções estão mergulhadas em momentos históricos e sociais que são refletidos nos pensamentos construídos.

\subsubsection{Por Um Conceito De Lazer...}

A aproximação dos estudos sobre o lazer, na presente pesquisa, teve início a partir da leitura de Dumazedier (1976). Considerado um clássico neste campo e muito utilizado como referencial teórico, ele define lazer como:

Um conjunto de ocupações às quais o indivíduo pode entregar-se de livre vontade, seja para repousar, seja para divertir-se, recrear-se e entreter-se, ou ainda para desenvolver sua informação ou formação desinteressada, sua participação social voluntária ou sua livre capacidade criadora após livrarse ou desembaraçar-se das obrigações profissionais, familiares e sociais. (p.34)

A proposta do Projeto Andanças, grupo de passeio para pessoas com deficiência e objeto de estudo deste Mestrado, pôde ser identificada como

\footnotetext{
${ }^{5}$ Munnè (1980), entretanto, observa que a condição humana é dialética e, portanto, as ocupações do tempo livre, assim como outras condutas humanas seriam, a rigor, auto e heterocondicionadas. $\mathrm{O}$ heteroconcionamento diz respeito às esferas coletivas que influenciam o autocondicionamento, que está na esfera do sujeito. Observa-se que condições de adoecimento, históricos ou sociais podem favorecer a prevalência de atitudes heterodeterminadas ou autodeterminadas das pessoas.
} 
atividades de lazer, a partir do trabalho de campo realizado. Numa primeira aproximação, o lazer foi compreendido a partir do senso comum e, assim, as atividades do Andanças como propositoras de momentos em que os participantes têm possibilidade de fuga e esquecimento das tensões e problemas cotidianos, de divertimento por si só. O conceito de lazer operado pelo Projeto, na óptica do pesquisador, pôde ser transformado com o contato aprofundado, como será abordado no decorrer desta escritura.

Inicialmente, realizou-se uma busca nos constructos teóricos por uma definição que pudesse abarcar o escopo de ações do Projeto Andanças. O conceito apresentado por Dumazedier (1976) serviu como ponto inicial de análise das práticas de passeios para as populações com deficiência, realizadas por serviços de saúde, instituições especializadas no atendimento dessas populações e o próprio trabalho acompanhado.

Se utilizada a definição de Dumazedier (1976) para analisar as práticas junto às populações com deficiência, os passeios podem cumprir as três funções estabelecidas pelo mesmo autor:

- o descanso (a liberação do cansaço físico como exigência do trabalho, no caso dos deficientes poderíamos considerar o cansaço como exigência das atividades de reabilitação);

- a diversão (o rompimento do tédio causado pela rotina diária);

- e o desenvolvimento (como opositor aos automatismos cotidianos e promotor de maior participação social das pessoas).

Entretanto, essa definição funcionalista mostra-se adequada apenas para uma análise simplista do lazer como recurso de inclusão social desta 
população. Pode-se utilizar este conceito numa perspectiva reducionista de reabilitação, sendo as atividades de lazer instrumento para "moldar o indivíduo de acordo aos padrões e normas impostos pela sociedade onde vive" (Souza et al., 2001, p. 27), de modo que o grupo reproduza esse determinado comportamento social.

No primeiro contato com o Projeto Andanças, corre-se o risco de se contaminar por uma sensação de que os participantes realizam os passeios apenas como reprodução de um comportamento social previamente determinado. Somente no acompanhamento da experiência e ao mergulhar no universo proposto pelo Projeto é que esta sensação pode ser desfeita. As microações que gestam a proposta emergem e possibilitam visualizar a tessitura da rede de relações que se forma a partir da experiência junto ao Andanças e da complexidade dos desdobramentos que se efetuam. Repercussões incluem o divertimento, o descanso e o desenvolvimento, mas os extrapolam.

A partir de uma perspectiva complexa, depara-se com a necessidade de ampliar o conceito de lazer, deixando de lado as definições de concepção burguesa - segundo classificação de Munnè, 1980, do qual Dumazedier (1976) é grande expoente. Nestes conceitos, a idéia de um estado subjetivo de liberdade e de expressão da personalidade remete a uma característica subjetivista; a separação do lazer da coletividade e a atribuição do lazer à esfera individual remetem a um caráter individualista; enquanto o caráter privado concebe uma característica liberal ao lazer (Mascarenhas, 2000). Para as pessoas com deficiências, os caracteres privados e individualistas destas concepções restringem o acesso à participação social, considerando a questão como problema 
do sujeito. ${ }^{6}$ Na proposta do Projeto Andanças, ao levar pessoas com deficiência aos espaços de lazer, dá-se visibilidade para a questão e aponta-a como uma problemática coletiva, envolvendo os diversos atores sociais.

As concepções de lazer, que Munnè (1980) define como burguesas, aparecem atreladas à compreensão de lazer no senso comum, e são caracterizadas com os atributos de gratuidade e informalidade (Mascarenhas, 2000). Carregados destes valores, os passeios e festas realizados em instituições que trabalham junto às populações com deficiência são, muitas vezes, vistos como ocupação com um fim em si. ${ }^{7}$ Assim, as reflexões sobre o sentido e o significado da proposta não ultrapassam a reprodução dos acontecimentos sociais dentro de determinado contexto cultural. Atividades que consensualmente são denominadas lazer constituem os cotidianos institucionais sem, entretanto, receber tal denominação. Se, por um lado, isto evita a desvalorização de tais propostas na oposição de supervalorização do trabalho e desvalorização do lazer, por outro, mascara a possibilidade de discuti-las, já que, ao responder a uma lógica funcionalista, apresentam um "fim em si mesmas".

O Andanças não apresenta um espaço instituído para que os participantes discutam as propostas desenvolvidas e as experiências vividas. Este fato, entretanto, não torna a prática do Projeto como algo com um "fim em si mesmo", pois ele opera microações que marcam a existência de seus participantes e desdobram-se em outros contextos de vida para além dos passeios. A operacionalização do Projeto carrega as características que Inforsato (2010) atribui à festa:

${ }^{6}$ Este pensamento tem identificação com a perspectiva da inserção social, que norteava as ações em relação à população com deficiência até a década de 1980, que considera esta questão um problema individual. Ver o cap. 1, subtt. 1.2 A participação social das pessoas com deficiência.

${ }^{7}$ Esta reflexão é construída a partir da experiência profissional da pesquisadora como terapeuta ocupacional e em conexão com a constituição e gestão do Projeto Andanças. 
[...] um lugar não compulsório, que em sua subtaneidade desajusta as posições habituais, desarranja as formas usuais admitidas ou esperadas socialmente. Um evento fora do ritmo de vida rotineiro, algo que se inscreve na dimensão do prazer, desconhecida para muitos deles, ou só conhecida de um modo primário em masturbações e empanturramentos. (p.111; Grifo nosso)

Assim, os passeios do Andanças deslocam-se da lógica funcionalista de reprodução de um comportamento social, constituindo um evento fora do ritmo de vida rotineiro, para os participantes do Projeto e dos demais atores sociais envolvidos na cena. O grupo de pessoas com deficiência, ao chegar subitamente aos locais por onde passeia apresenta o inusitado para o próprio grupo e, também, para os demais presentes. É necessário desmanchar formas preestabelecidas para se relacionar com as diferenças que se explicitam e criar novas configurações, que são posteriormente resgatadas nas vivências cotidianas.

Buscar e construir uma compreensão de lazer que auxilie uma apreensão da experiência do Projeto Andanças convida a uma aproximação das produções realizadas no campo do Lazer e da construção histórica do conceito.

\subsubsection{Traços Da História: As Produções Sobre Lazer No Brasil}

Para Peixoto (2007), os estudos do lazer constituem

[...] um conjunto disperso e multidisciplinar de abordagens dos problemas relativos à fruição do tempo livre do trabalho a partir de áreas de conhecimento e referenciais teóricos diversificados, acompanhadas ou não de proposições. (p. 15) 
A autora destaca que o tema do lazer apresenta um caráter multidisciplinar, questão que emerge a partir da diversidade de áreas que tratam da problemática. ${ }^{8}$ Em sua pesquisa Peixoto $(2007$, p.48) identifica seis focos de preocupação que norteiam as produções na área do lazer. São eles: (1) preocupação com o modo como os diferentes segmentos sociais ocupam e compreendem o seu tempo livre. Este primeiro constituindo-se como eixo central da produção de conhecimento acerca do tema; (2) preocupação com a implementação do lazer enquanto política pública ou privada; (3) preocupação com a seleção e formação dos profissionais da área do lazer; (4) preocupação com a história das práticas sociais, das políticas públicas e da produção do conhecimento acerca do lazer; (5) preocupação com o mapeamento da produção sobre lazer no Brasil; (6) preocupação com a "produção de teorias explicativas para a prática social do lazer no modo capitalista de produção e reprodução da existência e suas potencialidades emancipatórias”.

A predominância de trabalhos que enfatizam a forma como o tempo livre é (ou deveria ser) ocupado pelos diferentes segmentos sociais e, também, de produções sobre políticas públicas, reflete o contexto social, histórico e político do Brasil (Peixoto, 2007).

Mascarenhas (2000, p. 20-1) observa que as intervenções e construções teóricas no âmbito do lazer são historicamente "associadas às relações de poder e aos interesses de instrumentalização do chamado tempo livre”.

\footnotetext{
${ }^{8}$ Peixoto (2007) relata que as produções regulares realizada até a data de sua pesquisa provêm das seguintes áreas (segundo a Tabela de Áreas do CNPq): sociologia (do lazer e do trabalho); direito do trabalho (repouso do trabalhador); filosofia; etimologia; história; geografia; administração; economia; arquitetura e urbanismo; matemática (metodologias); enfermagem; turismo e hotelaria; educação física (recreação e lazer); antropologia cultural; pedagogia (educação lúdica, educação para e pelo lazer); psicologia.
} 
Nas décadas de 1920, 1930 e 1940 é construída no Brasil uma política de recreação, para ocupar os menores (considerando os acordos relativos à exploração da força de trabalho feminina e infantil) e o tempo livre dos trabalhadores. Dessa forma, possibilitava-se a recuperação física e a contenção das mobilizações de classes trabalhadoras, além de favorecer a formação de crianças nesta valorização do trabalho. Essas características permanecem nas produções sobre o tema também nas décadas de 1950 e 1960, através de manuais com "receitas de jogos, brinquedos e brincadeiras" (Peixoto, 2007, p.111).

Na década de 1970, o lazer passa a ser visto como possibilidade de consumo e instrumento potencial para veiculação de normas e valores. Neste período, marcado pela Ditadura Militar, configuram-se apontamentos de diretrizes para uma política nacional de lazer, juntamente com uma preocupação em mapear os interesses e conteúdos culturais do lazer. O lazer passa a constituir um "conjunto de atitudes a serem cultivadas pelo indivíduo". É neste mesmo período que o SESC (Serviço Social do Comércio), sob forte influência dos trabalhos de Dumazedier (1976), consolida o lazer enquanto campo de conhecimento no Brasil, desenvolvendo estudos e pesquisas institucionais. Assim, o lazer constitui um dispositivo e os usos do tempo livre saem da informalidade, configurando pesquisas institucionais e a distinção teórica entre ócio e lazer. Separação que, ainda hoje, se encontra pouco estabelecida fora deste campo de estudo, com a contaminação dos diferentes valores atribuídos a cada termo. (Mascarenhas, 2000; Peixoto, 2007).

Sant'Anna (1994) relata que, no período entre os anos de 1969 e 1979, a problematização sobre os usos do tempo livre no Brasil cresceu significativamente, como aumento do número de pesquisas, debates, o surgimento de programas de lazer, além da criação de setores institucionais específicos. O 
tema passou a ser mais abordado em jornais, revistas, televisão, e também nos encontros sobre questões políticas, médicas, culturais, nas entidades sindicais e de assistência aos trabalhadores e projetos arquitetônicos.

Somente na década de 1980 surgem novas vertentes no pensamento sobre lazer e configuram-se outros espaços para a produção e difusão do conhecimento neste campo. O lazer passa a ser apontado como saída para a crise econômica e o desemprego em massa que marcaram o período, ${ }^{9} \mathrm{sem}$, entretanto, uma discussão devidamente aprofundada da complexidade e viabilidade de tal proposição, considerando o quadro de desigualdade social brasileira na época (Mascarenhas, 2000; Peixoto, 2007).

Os estudos do lazer no Brasil constituíram-se majoritariamente como objeto de pesquisa no campo da Educação Física, como demonstrado no trabalho de Gomes e Rejowski (2005). Ao construírem um panorama da Pesquisa Científica em Lazer no Brasil, identificaram, no período de 1972 a 2001, 292 dissertações de mestrado, 42 teses de doutorado e 2 de livre-docência sobre o tema lazer, dos quais $80 \%$ dos trabalhos (mestrado e doutorado) foram produzidos a partir da década de 1990 e 20\%, na área da Educação Física. As autoras buscam analisar as produções levantadas a partir dos campos disciplinares onde foram produzidos e, também, sob categorias de assuntos, ${ }^{10}$ não havendo qualquer referência dos temas levantados a populações específicas. A categoria "Lazer e Saúde" é um dos que apresenta maior ocorrência nos últimos anos estudados.

\footnotetext{
${ }^{9}$ Sobre o assunto, consultar: Hobsbawn, 1995 (citado por Peixoto, 2007

${ }^{10}$ As categorias de análise das produções de lazer utilizadas pelas autoras: "Lazer Doméstico", "Lazer e Comunidade", "Lazer e Cultura”, "Lazer e Educação", "Lazer e Espaço Urbano”, "Lazer e Esporte”, "Lazer e Família”, "Lazer e História”, "Lazer e Meio Ambiente”, "Lazer e Política”, "Lazer e Saúde”, "Lazer e Tempo Livre", "Lazer e Trabalho", "Lazer Extra-Doméstico" e "Outros - Consumo e comportamento de lazer". (Gomes e Rejowski, 2005).
} 
Sá (2009) realiza um estudo sobre as produções de lazer no Brasil no período de 1972 a 2008, buscando identificar os pressupostos ontológicos da produção do lazer na pós-graduação em Educação Física no Brasil. A autora relata que os anos 2004, 2005 e 2006 foram os anos mais quantitativamente produtivos: é neste período que se encontram $51 \%$ (43 produções) das produções levantadas em seu trabalho. De um total de 84 pesquisas analisadas, $26,1 \%$ foram realizadas na área da Educação e 21,4\%, na área de Educação Física. As demais estão distribuídas em diferentes áreas de concentração, ${ }^{11}$ o que a autora aponta como uma fragmentação da produção de conhecimento. Assim como Peixoto (2007), Sá (2009) aponta para a necessidade de estudos que apreendam a complexidade do lazer.

Martinelli (2008), a partir do trabalho de Neto (1993), assinala que os estudos do lazer para as pessoas com deficiência no Brasil enfocam a adaptação de atividades e, em sua maioria, em caráter de reabilitação, de forma a favorecer a participação dessa população. Apesar de o autor não se referir ao campo destas produções, esta informação remete a um campo de atuação da Terapia Ocupacional. Ainda nas pesquisas nacionais, o lazer é pouco citado como facilitador dos contatos pessoais, das escolhas do sujeito, do crescimento pessoal, do desenvolvimento de interesses e da participação social. Nas produções internacionais, alguns estudos (Bronder, Cooper, 1994; Rogers, Hawkins e Eklund, 1998) sobre a escolha, interesse e desejos das atividades de lazer das pessoas com deficiência, favorecendo atitudes de autonomia e independência, são identificados. Entretanto, não há menção sobre discussão acerca da uma definição de lazer (Martinelli, 2008).

\footnotetext{
${ }^{11}$ Além das áreas da Educação e Educação Física, a autora identifica áreas de concentração onde foram produzidas as pesquisas estudadas, com representações entre $1,1 \%$ a 4,8\% cada área, diferentes daquelas apontadas por Peixoto (2007).
} 
Martinelli (2008) assinala que na literatura nacional o lazer é pouco pesquisado no que refere às populações com deficiência. É possível observar nos estudos que abordam o estado da arte do lazer no Brasil, nos quais, em sua maioria, não há menção direta a trabalhos envolvendo as intervenções e discussões acerca das populações com deficiência.

Em pesquisa bibliográfica realizada em novembro de 2009, na Bireme, ${ }^{12}$ sobre as produções referentes a atividades de lazer e pessoas com deficiência, foram identificados 29 trabalhos publicados desde 1990. Entretanto, na pesquisa utilizando os mesmos termos na ISI Web of Knowledge ${ }^{13}$ são encontrados apenas 9 trabalhos, sendo o mais antigo datado de 2005. Observa-se que, em relação à produção internacional sobre lazer e populações com deficiência, esse espaço, mostra-se crescente, porém de forma discreta.

A dificuldade na identificação de produções que tratam sobre lazer e pessoas com deficiência foi verificada nos levantamentos bibliográficos realizados. Alguns trabalhos não localizados nos levantamentos, sob os termos atividades de lazer e pessoas com deficiência e que abordam os temas, mesmo que eles não configurem elementos centrais, foram encontrados posteriormente ${ }^{14}$ e contribuíram significativamente para as reflexões aqui expostas. Este fato exemplifica a dispersão dos trabalhos sobre lazer, nas diferentes áreas de conhecimento, e indica a importância de se realizar uma pesquisa que possa reunir tais produções, e discutir os diferentes termos utilizados para as atividades que podem ser chamadas de lazer, nas diversas perspectivas teóricas.

\footnotetext{
${ }^{12}$ Centro especializado da Organização Pan-Americana de Saúde, responsável pela Biblioteca Virtual em Saúde (BVS). Escolheu-se a Bireme para a pesquisa por se tratar de um instrumento que congrega importantes bases de dados da área da saúde tais como (LILACS, IBECS, MEDLINE, Biblioteca Cocrhrane, Scielo), campo onde está inscrito inicialmente este trabalho.

${ }^{13}$ Base de dados escolhida para a pesquisa por apresentar como proposta a possibilidade de acesso a publicações com o cruzamento das áreas da saúde, artes e humanidades.

${ }^{14}$ Como os trabalhos de Martinelli (2008) e Aoki (2009).
} 
Diante deste panorama, pode-se voltar a atenção para o fato de o Projeto Andanças não mencionar, em qualquer dos seus documentos, o termo lazer, referindo-se à sua proposta como facilitadora de acesso das populações com deficiência, do Município de Ribeirão Pires, a passeios, eventos e outras atividades culturais. Ao abster-se de uma discussão sobre o lazer, o Andanças deixa de lado uma possível contaminação preconceituosa da proposta: não permite que suas ações sejam consideradas como ocupação por si do tempo dos seus participantes. Sob olhar da pesquisadora, o lazer surge como tema central de intervenção do Projeto Andanças, com caráter questionador do próprio sistema econômico e social vigente: pensar a participação social de populações tradicionalmente consideradas não produtivas, através de atividades também não produtivas.

\subsection{Interfaces: Questões Sobre Lazer, Saúde E Terapia OCUPACIONAL}

Para discorrer sobre a participação social de um grupo de pessoas com deficiência, a partir das atividades de lazer, propõe-se que esta trajetória teórica aborde algumas aproximações do campo do Lazer com o da Saúde e com o da Terapia Ocupacional.

É no campo da Saúde que historicamente constituíram-se os saberes em relação às populações com deficiência. Observa-se, desde a década de 1960, que as discussões acerca dos cuidados dessas populações buscaram a responsabilidade de outros setores sociais. 
O campo da Terapia Ocupacional desenvolve-se inscrito na grande área da Saúde e constitui-se como profissão responsável pelo cuidado da população com deficiência. Com o desenvolvimento das diferentes práticas e abordagens, as ações e intervenções deslocam-se para outros campos (como os da Educação, da Cultura, do Lazer), acompanhando a ampliação da circulação social das populações atendidas.

\subsubsection{Relações Sobre Lazer E Saúde}

No campo da saúde, os estudos do lazer ganham cada vez mais espaço, conforme pesquisa já mencionada de Gomes e Rejowski (2005). A participação social e a realização de atividades são atributos das diferentes áreas do viver, que apresentam crescente importância na compreensão dos processos saúde-doença.

No Modelo de Funcionalidade e Incapacidade, proposto pela OMS (Organização Mundial de Saúde) e expresso pela CIF (Classificação Internacional de Funcionalidade, Incapacidade e Saúde), tais características são entendidas como componentes que interferem diretamente nas condições de saúde das pessoas. Nesta classificação, Atividades e Participação $^{15}$ descrevem domínios de funcionalidade do sujeito, tanto individual quanto socialmente, nas diferentes áreas da vida. ${ }^{16}$ Assim, é possível

\footnotetext{
${ }^{15}$ A classificação proposta pela CIF descreve situações relacionadas às funções do ser humano, sendo divididas em: 1 - Componente da Funcionalidade e Incapacidade (que compreende as estruturas e funções dos sistemas do corpo e o desempenho e capacidade nas atividades e participação); 2- Componentes dos Fatores Contextuais (que compreende o ambiente físico, social e de atitude no qual as pessoas vivem e levam suas vidas) (OMS, 2003).

${ }^{16}$ A CIF utiliza uma lista única que considera cobrir a faixa completa das áreas da vida. São elas: 1Aprendizagem e aplicação do conhecimento; 2-Tarefas e demandas gerais; 3-Comunicação; 4-Mobilidade; 5-Cuidado Pessoal; 6-Vida doméstica; 7-Relações e interações interpessoais; 8-Áreas principais da vida; 9-Vida comunitária, social e cívica (OMS, 2003).
} 
descrever a execução de uma ação (atividade); o envolvimento da pessoa em uma situação da vida (participação); as dificuldades que podem ser encontradas para realização da atividade (limitações da atividade); e os problemas enfrentados quando o sujeito se envolve nas situações (restrições de participação). O lazer encontra-se no capítulo referente às ações e tarefas necessárias para a participação da vida social fora do âmbito familiar, mas incluído nas áreas da vida comunitária, social e cívica. No item Recreação e Lazer, são listadas atividades dentro de desígnios de ação: jogar; praticar esportes; arte e cultura; artesanato; hobbies; e socialização, mas também abre-se espaço para outras especificações e se considera que o item possa não ser especificado (OMS, 2003). A listagem de atividades incluídas como campo do lazer (apesar da possibilidade de descrever outras) indica um conceito a partir de determinados fazeres predefinidos quanto ao campo de ação humana.

A CIF constitui um marco importante junto às famílias de classificações da OMS. Diferentemente de outras propostas, de classificação para diagnóstico médico, a CIF propõe descrever estados de saúde e inclui em seu escopo uma abordagem que não difere entre pessoas com e sem deficiência.

Apesar de uma compreensão ampliada de saúde, observa-se na CIF uma centralidade na categoria trabalho, à medida que descreve como Áreas Principais da Vida aquelas voltadas diretamente para assegurar o funcionamento do sistema econômico vigente: educação, trabalho, emprego e transações econômicas, sendo o lazer incluído no escopo de ações realizadas no período de não trabalho. 
Pondé e Cardoso (2003, p.165), partindo de produções internacionais, abordam o lazer como fator de proteção da saúde mental, compreendendo-o a partir de dois vieses: como "uma série de atividades realizadas fora do domínio do trabalho"; e na consideração de "qualidades subjetivas subjacentes às atividades que as qualificam como sendo lazer". Afirmam, entretanto, encontrar limitações nessas produções de "modelos biomédico e psicológico em estudos do lazer", à medida que apresentam a problemática como individual (p.171). Estas questões remetem a uma determinada concepção de homem, trabalho e lazer que refletem o próprio modelo biomédico e correspondem ao contexto da pesquisa, pautado no campo de estudos norte-americanos sobre lazer.

Já no campo do lazer, em pesquisa brasileira, ao estudar sua importância na promoção de saúde em clínica e hospitais com profissionais desta área, Pinto (2006) observa que, embora considerado como um componente na promoção de saúde pelos entrevistados, o lazer não se constitui como "conhecimento sistematizado e complexo que exija a atuação de pessoal específico e preparado teoricamente e tecnicamente para desenvolver um trabalho dentro das clínicas e hospitais" (p. 76). Observa-se, assim, que, apesar da valoração positiva atribuída ao lazer no campo da saúde, as concepções do senso comum prevalecem na compreensão das intervenções realizadas.

Pinto e Gomes (2008) relatam que o lazer é amplamente mencionado em diversos documentos oficiais, como a Declaração dos Direitos Humanos, a Constituição Federal Brasileira e a Política Nacional de Saúde no Brasil, compreendendo-o como um determinante social na promoção de saúde. Entretanto, observam que o debate sobre o lazer não é realizado nestes mesmos documentos e acaba sendo visto como um fenômeno social de menor importância. 
Já a Carta Internacional de Educação para o Lazer, elaborada pela Associação Mundial de Recreação e Lazer, sem apresentar hierarquia das diferentes áreas do viver, enfatiza a importância do tema para a saúde,

[...] através da área específica da experiência humana com seus próprios benefícios - liberdade de escolha, criatividade, satisfação, diversão e aumento de prazer; promove a saúde e o bem-estar geral, oferecendo uma variedade de oportunidades que possibilitam aos indivíduos escolherem atividades e experiências que se adequem às suas próprias necessidades, interesses e preferências; direito humano básico, como educação, trabalho e saúde, entre outros. (Farias e Servo, 2005)

A inclusão do lazer nas discussões da área da Saúde reflete as discussões do campo, no que refere à própria conceituação do termo. A definição estabelecida pela OMS em $1978^{17}$ vem sendo questionada e pode ser considerada como um conceito não definitivo, assim como o conceito de doença. Estes constituem um processo e dizem respeito "à sobrevivência, à qualidade de vida ou à própria produção da vida" (Brasil, 2005, p. 39).

Faz-se importante marcar que deficiência não é o mesmo que doença. Historicamente, a associação os dois termos pode ter se originado no século XVI, quando

[...] a deficiência, a diferença e as questões incompatíveis com o padrão adotado como normal deixam de pertencer exclusivamente ao campo de influência da Igreja para se tornar objeto da medicina. (Pereira, 2006, p.20)

${ }^{17}$ A OMS define saúde, em 1978, como "um estado completo de bem estar físico, mental e social” (Brasil, 2005, p. 29). 
É, a partir de então, que a ideia de normalidade começa a ganhar força. Naquele momento, a doença implicava a cura e o retorno ao estado normal, a saúde.

Hoje, compreendendo a vida a partir das ressonâncias do pensamento de Maturana e Varela (2003), observa-se que os seres vivos se organizam de maneira a gerar regularidades internas, sob contínuas perturbações do meio e as de seu próprio funcionamento. Há a manutenção de uma organização específica (o de ser vivo) que se mantém a partir de constantes modificações na estrutura do ser. A vida implica, portanto, processualidade, movimento e criação. Assim, pode-se compreender a doença como uma das perturbações do meio, em relação ao ser vivo. E a saúde configura, então, a manutenção da vida, na reorganização do ser diante da perturbação-doença.

Nas palavras de Canguilhem (2000), a doença imprime uma descontinuidade na história do ser vivo, provocando profundas modificações. Trata-se de um estado contra o qual se luta para continuar a viver e que possibilita a instauração de uma nova ordem vital.

A saúde e a doença são categorias que remetem ao plano da experiência. Quarentei (2001, p. 2) compreende a vida como um "continuum incessante de atividades"; o ser humano está o tempo todo em múltiplas atividades: fazendo, falando, pensando. Assim, para a autora, as atividades humanas são matérias que produzem a vida. Lima (2006) afirma que retornar a um estado saudável equivale a retomar uma atividade interrompida ou equivalente, saindo de um estado de impotência e sofrimento. Trata-se da 
[...] afirmação da vida como força criadora, sua potência de expansão, o que depende de um modo estético de apreensão do mundo. Tem a ver com a experiência de participar na construção da existência. (Rolnik, 2001, p. 6)

Nas situações de deficiência, a sua instauração pode constituir um rompimento na continuidade da história do sujeito e sua família. Entretanto, não tem necessidade de configurar-se como doença: paralisia, impotência, interrupção do fluxo de atividades. Ao contrário, imprime, no sujeito, um novo modo de ser, de estar e se relacionar com o mundo.

\subsubsection{Lazer E Terapia Ocupacional: Alguns Pontos De Contato}

A utilização de atividades humanas com fins "terapêuticos" remonta à Antiguidade: "acreditava-se que os trabalhos, exercícios, artes e artesanatos poderiam 'curar' aqueles que estivessem ‘possuídos pelo demônio' e a todos os doentes eram oferecidas ocupações" (Carlo e Bartalotti, 2001, p. 19). Em meados do século XIX e início do século XX, encontram-se referências brasileiras quanto ao "uso terapêutico das ocupações" em instituições asilares para doentes mentais, sob orientação médica (Castro el al., 2001). No final da década de 1950 e início da de 1960, no Brasil, surge a Terapia Ocupacional, ${ }^{18}$ profissão que vem para, inicialmente, ocupar os doentes crônicos em hospitais

${ }_{18}$ A Federação Mundial de Terapia Ocupacional (World Federation of Occupational Therapy - WFOT) define Terapia Ocupacional como a profissão que lida com a promoção da saúde e com o bem estar, através das ocupações. O primeiro objetivo de um terapeuta ocupacional é possibilitar que as pessoas participem das atividades da vida diária. Os terapeutas ocupacionais atingem esse objetivo possibilitando as pessoas a fazerem coisas que melhore suas habilidades de participar ou modificando o ambiente para melhor suporte na participação (WFOT, 2009). 
gerais e restabelecer a capacidade funcional dos incapacitados físicos. Para isso, foram utilizadas três formas de atividade humana como abordagem terapêutica, que constituem historicamente a Terapia Ocupacional: o trabalho; a recreação; e o exercício (Soares, 1991).

A utilização de atividades humanas como recurso de intervenção em saúde pressupõe uma discussão sobre trabalho. Como aponta Marcassa (2003), essa noção é crucial na compreensão de qualquer fenômeno social, já que estes são derivados da forma como os homens se relacionam entre si e com a natureza. Dessa forma, criam as condições de produção e reprodução de sua própria existência. A autora utiliza a definição de trabalho de Karl Marx (1971), como criador de valores de uso, sendo, assim, indispensável à existência humana em qualquer sociedade. Nesta definição, o intercâmbio material entre o homem e a natureza é essencial para manutenção da vida humana.

A partir do percurso histórico de constituição da Terapia Ocupacional como profissão, pode-se traçar um paralelo com as discussões realizadas no campo do Lazer. São campos que se constituem inicialmente a partir de um ponto em comum: a questão do trabalho. Não foram encontradas produções que aproximem as discussões teóricas desses dois campos.

Enquanto os terapeutas ocupacionais trabalham para recuperar as capacidades funcionais de seus pacientes, "habilitar e/ou reabilitar e inserir no mundo do trabalho uma população que dele estava alijada" (Watanabe e Nicolau, 2001, p. 155-6), os trabalhadores em todo o mundo lutavam pela redução da jornada de trabalho, a configuração dos direitos trabalhistas. Miranda (2004) relata que 
[...] desde 1886, com o Congresso Internacional dos Trabalhadores, em Genebra, a luta pela redução da jornada de trabalho é vista como condição preliminar para a própria emancipação dos trabalhadores. (p. 47)

Os trabalhadores buscavam sair das condições de exploração e opressão, e os deficientes buscavam inserir-se, mesmo que de maneira diferenciada, nesta dinâmica social. As diferenças que restringem o acesso dos deficientes às normas estabelecidas de produção e denunciam a massificação das relações e possibilidades de cada sujeito (independente de uma situação de deficiência) pouco eram admitidas nos locais sociais do trabalho. Seria melhor aos olhos relegá-los ao lugar da caridade, o que ressaltava (além da incapacidade do outro deficiente) as capacidades e a função socioeconômica das pessoas sem deficiência.

Com o advento da modernidade e a vigência da visão de mundo mecanicista, a deficiência, assim como a doença ou qualquer diferença, é vista como uma anomalia da máquina-corpo. As pessoas com deficiência eram, então, alvo da filantropia, realizadas por instituições de caridade. Nesses locais, o estigma de invalidez e incapacidade foi reforçado, sendo as populações com deficiência objetos da caridade alheia. No século XVIII, com a Revolução Industrial, as pessoas passam a ser reconhecidas socialmente de acordo com as suas possibilidades de produção. O estigma de incapacidade é reforçado. Assim, no dia a dia, com o advento do capitalismo, as pessoas com deficiência eram deixadas à margem do sistema social (Pereira, 2006).

Farias e Servo (2005) observam que a falta de informação da sociedade com relação aos deficientes constitui um grande problema nas relações desses 
sujeitos com o mundo, gerando predisposição para condutas impeditivas da participação social dessa população.

Pode-se, então, afirmar que o trabalho de inclusão social das populações com deficiência, historicamente, tem início a partir de atividades socialmente valorizadas, seja em função de necessidades sociais (como a necessidade de absorção de incapacitados à força de trabalho, que culmina no surgimento da Terapia Ocupacional nos Estados Unidos no início do século XX), seja como forma de valorizar as capacidades das populações com deficiência (Soares, 1991).

Lima e Pastore (2010) realizaram um levantamento bibliográfico em periódicos brasileiros específicos da área da Terapia Ocupacional, e que versam sobre atividades, no período de 1990 a 2008. Encontraram uma produção significativa que menciona o lazer como campo de atividades: 37 artigos, correspondendo a $18 \%$ do material coletado. Entretanto, quando analisam as produções em relação à terminologia utilizada, não há menção do lazer, assim como não há referências quanto à discussão conceitual do tema.

Cavalcanti (2007) descreve as atividades de lazer e recreação como campos de intervenção do terapeuta ocupacional e as compreende como ocupações humanas, determinantes de saúde, em que os indivíduos gastam tempo, despendem energia e adicionam significação à vida. São atividades desempenhadas espontaneamente que compõem as áreas de ocupação de crianças e adultos.

No Brasil, os terapeutas ocupacionais, tradicionalmente, não aplicam instrumentos padronizados de avaliação para informar sobre o lazer. Entretanto, Cavalcanti (2007) aponta alguns terapeutas ocupacionais que vêm sistematizando a aplicação de instrumentos utilizados na prática norte-americana. 
Entre eles, cita:

- 'Inventário para Avaliação do Lazer do Adulto’ (Matsutsuyu, 1969);

- 'Histórico Lúdico' (Takata, 1969);

- 'Escala Lúdica Pré-Escolar' (Knox, 2002);

- 'Escala de Brincar da Criança'(Barnett, 1991);

- 'Teste do Entretenimento' (Bundy, 2002).

Os instrumentos 'Histórico Lúdico, a Escala Lúdica Pré-Escolar e a Escala de Brincar da Criança' apresentados pela autora como recursos de avaliação do lazer não utilizam o termo e abrangem a ação humana na infância como um campo constituídos de fazeres interrelacionados e fundados a partir de um sentido. A apresentação destes instrumentais junto ao 'Inventário para Avaliação do Lazer do Adulto' e ao 'Teste de Entretenimento' demonstra que o conceito de Lazer não parte de uma discussão teórica sobre o tema, confundindo-se com diferentes termos como brincar, lúdico e recreação.

A utilização de escalas e testes, para avaliar o desempenho na área de ocupação do lazer, podem padronizar a linguagem entre os profissionais e auxiliar nos objetivos da intervenção. Entretanto, carregam consigo as concepções de mundo, de sujeito, de lazer, a partir das quais foram formuladas, sejam elas opções teóricas claramente adotadas ou apropriações conceituais irrefletidas.

A questão apresentada merece a construção de novas reflexões para o aprofundamento desta discussão. No presente trabalho, atem-se a uma construção teórica do conceito de lazer, a partir de estudos do campo e de uma reflexão sobre as atividades humanas na contemporaneidade. Apesar da grande 
importância na discussão e conceituação dos termos brincar, lúdico, recreação e outros que são cotidianamente confundidos ou incorporados às noções de lazer, esta discussão não será aqui realizada.

Nas práticas profissionais dos terapeutas ocupacionais observa-se que as saídas, os passeios e outros momentos que podem ser denominados lazer constituem espaços desejados pelas pessoas atendidas. Marta Aoki (2009), em sua dissertação "Reabilitação com ênfase no território - demandas de pessoas com deficiência e a promoção da participação comunitária”, relata, a partir da experiência como terapeuta ocupacional, que os passeios constituíram uma demanda para o grupo estudado na pesquisa, o que ocorreu após uma primeira experiência. A autora relata uma das saídas, buscando dar visualidade à riqueza vivida e relatando que se trata de um momento raro na realidade daquelas pessoas com deficiência.

Na experiência do Andanças, a pergunta: "Quando será o próximo passeio?” era uma constante ao final de cada saída. Um desejo por repetir a proposta, configurando uma nova experiência, instaurando o desejo de novos contatos.

Retomando a concepção de Quarentei (2001, p.4) sobre atividades como matérias que produzem vida, o terapeuta ocupacional, como profissional que tem neste campo o seu instrumental, está, o tempo todo, envolvido com a "produção de modos de estar no mundo, de maneiras de existir e da própria fabricação de mundos”.

Desse modo, identifica-se a necessidade de ampliação dos estudos que articulem as intervenções dos terapeutas ocupacionais à temática do lazer, a fim de constituir ações que potencializem as práticas neste campo profissional. 
Utilizar as atividades humanas como instrumento de intervenção implica discutir os sentidos e significados destas em seus diferentes campos. Dessa forma, a aproximação dos campos do Lazer e da Terapia Ocupacional faz-se necessária para que as atividades de lazer desenvolvidas na área da saúde possam ser colocadas em questão, problematizadas, de forma a constituir campos de intervenções coerentemente vinculados a determinadas perspectivas teóricometodológicas. Talvez, somente desta forma o lazer possa ser compreendido como uma prática de produção de sentidos nas ações de promoção de saúde. Nas palavras de Mascarenhas (2000, p.1), "o lazer deve comportar sempre determinados conteúdos e características que o tornem expressão verdadeira da realidade em que esteja inserido", compreendendo-o, assim, como "tempo e lugar de construção da cidadania e exercício da liberdade", de forma a colaborar com a construção das normas sociais, os valores de convívio e o próprio questionamento da ordem vigente. Para o autor, pela "vivência e reflexão das atividades e conteúdos do lazer, espera-se garantir a apropriação de um saber correspondente às expectativas e reais necessidades" (p.17).

Considerando as dificuldades no acesso a atividades de participação social das pessoas com deficiência, o lazer pode constituir importante campo de intervenção para essas populações. Ampliar a circulação social das populações com deficiência, possibilitando que elas possam frequentar os diferentes lugares onde a sociabilidade acontece, traz repercussão para o território. Este, quando tem o seu cotidiano regularmente habitado pelas experiências com diferenças, a partir da convivência entre pessoas com e sem deficiência ou transtorno psíquico, pode provocar novos olhares e a abertura de novas vias de sociabilidade (Aoki, 2009; Samea, 2002). 
Nas atividades de lazer os traços do inesperado, do súbito, do desajuste das posições habituais, do desarranjo das formas usuais admitidas ou esperadas socialmente, do evento fora do ritmo de vida rotineiro, constituem um campo fértil para a participação das pessoas com deficiência e para o contato com as diferenças que emergem nas relações entre os sujeitos. A emergência dessas situações nos momentos de lazer é favorecida, ocasião em que as escolhas e decisões autodeterminadas predominam sobre as heterodeterminadas.

Para Martinelli (2008) a participação desta população nas práticas de lazer estimula contatos e possibilita a abertura de caminhos para a inclusão na comunidade. A autora aponta, entretanto, a partir do pensamento de West (1984), que a reações estigmatizantes e experiências negativas da população com deficiência com as pessoas sem deficiência configuram-se como barreiras para a participação delas na comunidade, o que indica a necessidade de uma intervenção para a construção de um novo olhar social para a população em questão.

Consideradas as práticas junto às populações com deficiência nos contextos reais da vida, compreende-se o lazer como prática social e campo de intervenção profissional de diversas áreas, com a necessidade de implicação transdisciplinar entre os diferentes atores envolvidos.

Galheigo (1999, p. 50-51) define didaticamente os conceitos de multi, inter e transdisciplinaridade, a partir das idéias de Japiassu (1976), Nicolescu (1997) e Morin (1996), sendo:

- multidisciplinaridade - "a interação de diferentes disciplinas, (...) sem se preocupar com o estabelecimento de laços de cooperação que signifiquem qualquer alteração no seu corpo teórico-metodológico"; 
- interdisciplinaridade - "a interação e reciprocidade de diferentes disciplinas cujo propósito é restabelecer o diálogo entre elas" com intercâmbio de métodos e conteúdos que podem ou não culminar na criação de novas disciplinas;

- transdisciplinaridade - "como uma etapa adiante da interdisciplinaridade, (...) quando haveria a superação das fronteiras entre as disciplinas". É fundamental ressaltar que "a transdisciplinaridade não se propõe a excluir esferas de competência”, mas busca desenvolvê-las, potencializando a articulação com outras competências (Galheigo, 1999, p. 51).

A autora propõe o exercício de múltiplos olhares para a problemática que for colocada em questão, pautando este pensamento no paradigma da complexidade.

Procura-se construir, aqui, uma revisão dos pontos de contato entre Lazer e Terapia Ocupacional, a partir das produções recentes neste campo de conhecimento

A interface Lazer e Terapia Ocupacional apresentada favorece o exercício do olhar para a problemática do lazer, a partir de um olhar terapêutico ocupacional, configurando novas composições entre diferentes áreas do conhecimento.

Os campos do Lazer e da Terapia Ocupacional fornecem elementos para construção de pensamentos críticos sobre a vida humana no mundo contemporâneo, através do olhar para a configuração das ações humanas. 


\subsubsection{O Lazer Enquanto Campo De Ação Humana}

Segundo Arendt (2000), são três as atividades fundamentais, correspondendo cada uma delas a uma condição básica da vida humana: o labor; o trabalho; e ação:

(i) O labor está ligado à manutenção da vida enquanto processo biológico, às atividades que asseguram a sobrevivência do sujeito e de sua

espécie. É caracterizado pelo ciclo, pois segue o ritmo corporal, estabelecendo intrínseca relação com a vida. Diz respeito às atividades manuais e repetitivas, que produzem coisas destinadas ao consumo, reproduzem a vida: fala da relação do sujeito com a vida.

(ii) $\mathrm{O}$ trabalho corresponde às atividades ligadas à fabricação, à construção do mundo. Objetiva a subjetividade de quem produz, pode combinar diferentes habilidades e vocações e produzir no homem satisfação pela sua realização. Diz respeito à relação do sujeito com o mundo.

(iii) A ação diz sobre a relação do sujeito com os outros homens, é a atividade exercida diretamente entre os homens. Corresponde à condição humana da pluralidade dos seres singulares, tecendo a teia de relações entre os homens.

A vida moderna, para Arendt (2000), e como ainda pode-se observar na contemporaneidade, reduziu as atividades humanas a uma única forma de fazer, caracterizado pelo labor, voltadas a assegurar as necessidades da vida do corpo biológico, produzindo-as e consumindo-as. O trabalho e a ação são suprimidos. O lazer, inserido nesta lógica, de produção e consumo, é capturado 
e atravessado pelo modelo moral e econômico do capitalismo, ${ }^{19} \operatorname{como}$ todos os tipos de atividade (Lima, 2006). Constitui, assim, atividade de manutenção de uma vida biológica, compondo o tempo que sobra do trabalho para recuperação das forças físicas e retorno à produtividade. As compreensões e práticas de lazer deixam de figurar como conquista dos trabalhadores assalariados e ficam restritas ao tempo de não trabalho, assumindo funções específicas: fuga dos problemas; recuperação das energias; compensação das frustrações; quebra da rotina (Gomes, 2008).

No pensamento de Arendt (2000), é necessário restituir o trabalho (ou a qualidade de construir um mundo comum) e a ação (ou a qualidade de tecer as relações humanas) às atividades dos homens (Lima, 2006).

Antunes (2009, p. 179) considera que o tempo disponível é concebido no mundo atual da perspectiva do capital "como algo a ser explorado no interesse na sua própria expansão e valorização”. Entretanto, para a construção de uma sociedade na qual a vida possa ser dotada de sentido, o autor, utilizando Kurz (1997) diz que o tempo disponível deve ser compreendido a partir da concepção do trabalho vivo, mostrando-se como

[...] condição para que a sociedade possa suprir seus carecimentos e necessidades efetivamente sociais e desse modo fazer aflorar uma subjetividade dotada de sentido dentro e fora do trabalho. Isso porque o tempo disponível será aquele dispêndio de atividade laborativa autodeterminada, voltada "para atividades autônomas, externas à relação dinheiromercadoria". (Antunes, 2009, p. 179-80)

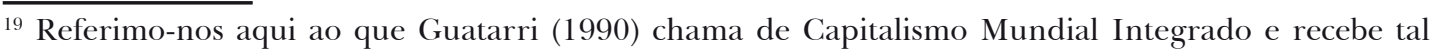
denominação "porque potencialmente colonizou o planeta e porque coloca no horizonte uma realidade em que nenhuma atividade humana e nenhum setor da produção ficam fora de seu controle" (Lima, 2006, p. 41-2).
} 
Para problematizar essa questão, recorre-se, também, ao olhar de Maturana e Varela (2003), que trazem uma alternativa para conceber e olhar o mundo: a vida biológica não pode ser destituída de todos os demais acontecimentos, como caracterizado na separação mente e corpo. É a partir da biologia, do corpo, que o ser humano acontece. Sendo a mente um fenômeno biológico que não pode ser separado da matéria, há necessidade de reconhecer que o fenômeno da existência está intrinsecamente atrelado ao da experiência, da ação do corpo no mundo (Maturana, 2006). As relações com a organização social e o sistema socioeconômico vigente constituem, assim, perturbações do meio na estrutura viva. Interações recorrentes que provocam modificações na estrutura do ser, assim como este provoca modificações no meio. A mudança estrutural causada pode, ou não, ir ao encontro da manutenção de formas de vida propostas pelo sistema capitalista. Ao invés de uma rede sem escapatória a qual se estaria fadado, fala-se que as possibilidades de sair destas amarras estão na interação com fatores que possibilitam a criação de redes de relação e a construção de um mundo comum.

Desse ponto de vista, da possibilidade de compreender o ser humano e o mundo em que vivemos, a partir de uma abordagem que integra as relações entre os seres com sua estrutura biológica e ambiente, seria preciso compreender quais são os fatores implicados nas interações entre os seres e o ambiente e que levam à restituição das qualidades, descritas por Arendt (2000), às atividades humanas. E possibilitar que esses mesmos elementos componham as relações de interações possíveis entre seres e ambiente.

No atual contexto, que tende a uma manutenção de formas de vidas pré-determinadas pelo sistema capitalista, pode-se inferir que muitas das ati- 
vidades humanas realizadas são pautadas na obrigação e esvaziadas de sentido, pois se prestam somente à manutenção de um corpo biológico, cindindo com a integralidade do ser.

O caráter espontâneo apresentado pelo lazer, por partir dos desejos de pessoas e grupos, abarcando inúmeras experiências de contato e recriação do universo cultural, possibilita fomentar e colaborar para construir novas normas, condutas e valores para o convívio social (Marcassa, 2003; Mascarenhas, 2000).

O lazer compreendido como "resultante das tensões entre capital e trabalho, que se materializa como tempo e espaço de vivências lúdicas, lugar de organização da cultura perpassado por relações de hegemonia" (Mascarenhas, 2000, p.17), possibilita a criação e recriação das manifestações cotidianas dos sujeitos, produzindo e não apenas reproduzindo cultura. Assim, trata-se de uma experiência coletiva, e não uma atividade fruída (Amaral, 2009).

No coletivo, o lazer permite o experimentar: "arriscar-se para além da posição dos resultados imediatos/ previstos/ 'desejados'; acolher o inesperado/ desconhecido/ o não escolhido!" Permite o apreciar: "deixar-se afetar pelo outro", ser tomado pelos efeitos dessa afetação, pelos sentimentos, percepções, sensações, pensamentos. Permite construir sentido, não como atribuição, mas como movimento: afirmar o acontecimento e o que ele produziu (Quarentei, 2006, p. 2-3). Nas experiências coletivas constrói-se um mundo comum e as relações humanas são tecidas no Experimentar, Apreciar e Afirmar.

Assim, as atividades de lazer são, em sua essência, espaços de relações sociais onde são construídos mundos, onde as interações possibilitam o desencadeamento de mudanças no sujeito e, também, de modificações no meio so- 
cial. Nestes espaços a participação é facilitada: a disponibilidade dos sujeitos para o diferente e o inusitado é espontânea, assim como para o envolvimento nas situações vivenciadas.

\subsection{Notas Preliminares Sobre Participação Social e} Alteridade

2.3.1 Sobre Participação Social

PARTICIPAÇÃ̃O s.f. (Do lat. Participatio, participationis.) Ato de participar; seu resultado.

PARTICIPAR v.t. (Do lat.participare.) (Conj. [4]) 1. Fazer saber, comunicar, anunciar. - 2. Tomar parte em. - 3. Associarse pelo sentimento, pelo pensamento; solidarizar-se com. -4 . Ter natureza semelhante ou qualidade comuns a alguém ou a algo. (Grande Dicionário Larousse, 1999).

Palavra muito utilizada no cotidiano das pessoas e com diferentes significados atribuídos: PARTICIPAR é convidar o outro a tomar parte, a estar junto, acompanhar. O leitor é, então, neste momento, convidado a adentrar uma discussão sobre concepções de PARTICIPAÇÃo SOCIAL e a construção do pensamento utilizado no presente trabalho.

Nas discussões acerca de participação social, encontram-se nas produções referentes à participação nos sistemas de saúde, definições diversas, que podem agrupar-se em dois tipos, segundo Vazquez et al. (2003): a participação como meio (perspectiva utilitarista) ou participação como fim. No primei- 
ro caso, a participação social é utilizada para alcançar objetivos definidos por instituições, para realização de intervenções prioritárias ou como alternativa estratégica emergencial. Na perspectiva de participação como fim, há o reconhecimento do direito da população de participar de decisões sociais que afetam a vida cotidiana e constituem-se como controle social das instituições.

Vazquez et al. (2003) enfatiza que, apesar das diferentes concepções e aplicações conceituais a respeito da participação social, esta se constitui como um processo, admitindo modalidades e escalas de participação diversificadas, como se pode observar na escala de Arteins (1969). Para este autor, a participação pode ocorrer em dois grande níveis: simbólico ou controle cidadão. O primeiro é caracterizado "pela falta de partilha de poder e, em sequência ascendente, considera participar como a utilização de serviços, informação, consulta e conciliação" (Vazquez et al., 2003, p. 580). O nível do controle cidadão "começa com a colaboração, inclui o poder delegado e, finalmente, alcança um grau denominado controle cidadão. Neste nível, a participação se expressa com o exercício de poder decisório, solidário e compartilhado” (p.580). Na passagem de um nível para o outro, o processo participativo fica mais exigente e complexo, implicando o cumprimento de uma série de requisitos e condições por parte do participante. O autor aponta um nó crítico: no descompasso entre o cotidiano das práticas e as conquistas no plano legal.

Para as populações com deficiência, o descompasso acontece não apenas na área da saúde, mas em diversos setores sociais. No Brasil, observa-se a instituição de leis que, apesar de nem sempre serem vistas em prática, objetivam favorecer a participação social dessa população, como a Lei Federal 7 853 de 1989 que "dispõe sobre o apoio às pessoas portadoras de deficiência, 
sua integração social”(...) (Brasil, 1989), com tomada de medidas nas áreas de saúde, educação, trabalho e edificações. Após essa Lei, outras foram criadas, indicando grandes avanços nas discussões e no plano teórico sobre o tema. Isto, entretanto, não demonstra o estado prático das ações em relação às pessoas com deficiência.

Lima (1983) realiza uma discussão sobre participação social, a partir de um olhar do campo da Assistência Social, apresentando dois enfoques. O primeiro, de um ponto de vista funcionalista, a partir do qual a participação é considerada como meio para obtenção de apoio que propicie a concretização de programas oficiais na área de desenvolvimento social. Nesse aspecto, a participação social pode ser dividida em passiva e ativa. A adaptação da população aos valores sociais vigentes, integrando-se, assim, à sociedade, configura uma participação ativa. O segundo enfoque, histórico-estrutural, considera que marginalidade e participação são geradas pelas diferentes etapas históricas, a partir das estruturas econômicas, políticas e ideológicas. Dessa forma, não há sentido em compreender a participação a partir de indicadores como atitudes, comportamentos e ideias. A autora defende que participação social “não pode ser vista apenas como uma variável explicativa básica que leva à constatação de minorias participantes e de uma massa da população passiva e inoperante" (Lima, 1983, p. 38), mas que as diferentes formas de participação apresentam-se numa constituição difusa, sendo os atos cotidianos, observados nas relações com o outro, indicadores de participação.

Considerando as perspectivas apresentadas, depara-se com concepções que abordam o universo macropolítico e micropolítico, termos utilizados a partir do pensamento de Rolnik (2008) e Guattari (1996). Para os autores as 
ações macro e micropolítica constituem maneiras de enfrentar as tensões da vida humana movimentando os pontos em que a dinâmica de transformação se encontra travada. Liberam o movimento vital para a saúde da sociedade. As ações macropolíticas agem nas tensões da realidade visível e dizível, nas estruturas molares (2008) As ações micropolíticas agem na tensão dos planos do sensível, invisível e indizível, nas estruturas moleculares (2008), ligadas às sensações e devires.

Ao tomar-se o pensamento de Vazquez et al. (2003), no que se refere às formas de participação como meio ou como fim, observa-se um olhar para um universo macropolítico, constituindo uma luta por direitos com ações que operam junto a valores e estruturas instituídas. A discussão levantada por Lima (1993) remete o leitor a um olhar micropolítico, aos interesses e desejos dos sujeitos e a relação destes com o universo social em questão, através dos atos cotidianos.

Ao considerar a participação simbólica e o controle cidadão para além dos serviços de saúde, mas na relação das populações com as diversas instâncias institucionais, o processo participativo tornar-se mais exigente, com a complexificação dos laços sociais que se constituem, possibilitando a construção, ampliação e fortalecimento de uma rede social de suporte. Tais laços são constituídos a partir dos atos cotidianos junto às relações próximas e que agregam novos fios ao tecido social, à medida que se expandem.

As relações sociais podem ser tomadas, assim, como um emaranhado que constituem uma rede, sendo cada sujeito um ponto componente da trama. No cotidiano, depara-se com composições e entrelaçamentos (ou não), a partir do modo como cada um se relaciona com os acontecimentos da vida. 
As relações percebidas como significativas para o sujeito e que contribuem para o próprio reconhecimento configuram as Redes Sociais de Suporte (Sluzki, 2006).

O desejo de participar das populações com deficiência expressa a grande vontade de estar "dentro da vida", nos seus modos únicos e singulares, e não à sua margem. Muramoto e Mângia (2007) afirmam que pertencer às redes sociais fortes e sustentadoras constitui fator de proteção à saúde, à medida que as relações sociais favorecem o encontro de um maior sentido à vida, atribuindo um lugar ao outro a partir da própria relação estabelecida.

A concepção de participação apresentada pela CIF (Classificação Internacional de Funcionalidade) traz as facetas macro e micropolíticas da participação, ao defini-la como envolvimento em uma situação da vida, que implicam situações diversas, como aprendizagem, comunicação e mobilidade à vida doméstica, relações e interações interpessoais e a atividades de educação, trabalho e emprego (OMS, 2003).

No presente trabalho, constrói-se uma concepção de participação social a partir das discussões apresentadas, como envolvimento em uma situação da vida, cujos indicadores de participação estão vinculados aos atos cotidianos, que favoreçam a constituição de uma rede social de suporte. A participação social das pessoas com deficiência apresenta, por um lado, um caráter micropolítico, caracterizado pela rede de relações constituídas e utilizadas no cotidiano do sujeito e da família, e por outro, um caráter macropolítico, caracterizado pela participação simbólica até o caráter de controle cidadão junto às diferentes instâncias sociais, às quais possa estar vinculado de alguma forma.

O movimento de luta das pessoas com deficiência mobiliza-se, no decorrer dos tempos, "em torno da própria questão da deficiência, com vistas 
a uma conscientização social". A partir destes movimentos, a deficiência vem sendo redefinida em termos positivos (Pereira, 2006, p.93).

As pessoas com deficiência e aquelas que constituem suas redes sociais de suporte (como as famílias, amigos, trabalhadores que atuam junto a essa população) construíram uma história de participação social com envolvimento em situações políticas da vida. Os avanços observados, como a abertura de discussões, a implantação de ações mundiais para favorecer e ampliar a participação nos diversos espaços sociais e, assim, possibilitar outros atos cotidianos para essas populações, foram construídos historicamente. Nesse percurso, observa-se a instauração de políticas e estudos com enfoque de ações macropolíticas, seja por iniciativa da sociedade ou dos movimentos de luta das pessoas com deficiência. Os resultados, muitas vezes, não conseguem apresentar as facetas micropolíticas de participação social dessa população. Dessa forma, atenta-se para a construção de ações que sigam nesta direção.

\subsubsection{Atualizando Conceitos e Criando Passagens: de uma} Sociedade Inclusiva para uma Sociedade da Diferença

A inclusão da pessoa com necessidades especiais é um processo relativamente novo. Durante décadas a realidade deste grupo sempre foi a exclusão. $\mathrm{O}$ sentimento de pertinência só era possível através do convívio com pares, com seus iguais, distantes do resto do mundo, fechados em associações especializadas. A história mostra que, num determinado momento, se pensou na inclusão como uma luta e conquista individual, e não como um direito, processo que foi denominado integração. O processo só passa a se denominar 
inclusão quando se torna uma questão de direitos e da sociedade se preparar para receber as diferenças. (IV Seminário Internacional Sociedade Inclusiva, 2006)

Valla (1998), ao escrever sobre participação social, chama a atenção do leitor para o fenômeno da modernização, que pressupõe superar atrasos tecnológicos e culturais de uma determinada sociedade, com o desenvolvimento de novas formas de produzir e consumir, das quais toda a população deve participar. Nessa forma de operar na relação com o mundo, os grupos ditos marginalizados devem, então, integrar-se a esse funcionamento, embora estejam fora desta dinâmica social em decorrência de sua própria ignorância e passividade. O mesmo autor ressalta que essa concepção, que apresenta raízes fortes em nossa sociedade, inspira diversas iniciativas que procuram integrar ou incluir as populações marginais.

Dubet (2010) propõe que as desigualdades sejam analisadas como “conjunto de processos sociais, de mecanismos e experiências coletivas e individuais" (p.11). Um aspecto importante a ser considerado é a obstinação de igualdade que cria tensões sociais a partir da modernidade. A igualdade, enquanto princípio, é estendida a todos para além das desigualdades sociais reais, sob a forma de homogeneização da sociedade. As desigualdades são múltiplas, resultando de um "conjunto complexo de fatores, aparecendo, mesmo, muitas vezes, como produto, mais ou menos perverso, de práticas sociais que têm como objetivo, justamente, limitá-las" (p. 22).

Nas múltiplas desigualdades vividas no contemporâneo, com tendência a uma homogeneização social em que todos devem modernizar-se, incluir pressupõe a criação de estratégias para que os excluídos sociais superem suas 
diferenças, através de um esforço pessoal de adequação às normas socialmente valorizadas. Inclusão de pessoas com deficiência como se ao oferecer-lhes oportunidade de participação a estas entrassem em um sistema do qual não faziam parte. E tais oportunidades configurando-se como possibilidade de superação da condição de deficiente para uma operacionalização de ser-normal.

Longe de considerar que a condição de deficiente apresenta um caráter a ser superado, compreende-se nesta dissertação que a deficiência configura uma característica constituinte do sujeito, portanto, longe de ser superada. Nas palavras de Pereira (2006), constitui uma diferença por vezes estampada no corpo e que, imprescindivelmente, se projeta na vida e no cotidiano do sujeito. Assim, não se fala em incluir essas populações na dinâmica social, mas que possam participar seus modos de ser configurando novas possibilidades no tecido social.

A participação social das pessoas com deficiência é atravessada pelas relações histórico-sociais junto a essa população, considerando as estruturas políticas e ideológicas vigentes, e apresenta característica difusa, conforme nomeado por Lima (1983). A pouca participação das pessoas com deficiência numa dimensão macropolítica, nos diversos setores sociais comuns, denuncia um caráter ainda insuficiente das possibilidades oferecidas a essa população. A participação, em sua dimensão micropolítica, é estabelecida nas relações cotidianas, no ambiente social onde vivem. Nos atos cotidianos, as pessoas com deficiência provocam uma tensão social, escancarando as diferenças nas relações sociais e convocando o outro a vivenciá-las: as situações de alteridade.

O Projeto Andanças, em suas atividades de lazer, amplia o escopo de ações cotidianas de seus participantes. Assim, convoca os diferentes sujeitos 
que compõem o tecido social, a apreciar as cenas produzidas: deixar-se afetar pelas sensações, sentimentos, pensamentos produzidos (Quarentei, 2006), favorecendo a contínua reconfiguração do tecido social.

Aparentemente uniforme, o tecido social parece sofrer um abalo ante o inusitado, o diferente: pede por novas texturas, ondulações, dobras. Reconfigurações que acolham as diferenças.

\title{
2.3.3 Alteridade: A Diferença Como Singularidade e Similaridade do Ser Humano
}

\begin{abstract}
ALTERIDADE s.f. (Do lat. Alteritas.) Estado, qualidade daquilo que é outro, distinto. (Anton. De IDENTIDADE). (Grande Dicionário Larousse, 1999).
\end{abstract}

Os passeios realizados no Projeto Andanças aconteciam sob curiosos olhares, em geral carregados de um estranhamento pela visualidade da situação que se colocava diante das pessoas: três cadeiras de rodas conduzidas pelos próprios usuários, quatro cegos e outras pessoas cujas dificuldades para andar ou falar só podiam ser percebidas a partir de um olhar atento, já despertado pelos primeiros.

As diferenças eram escancaradas à medida que permaneciam próximas, chamando a atenção para si. O pequeno grupo de participantes circulava lado a lado pelo espaço e suas deficiências aglutinadas mobilizavam, nos outros atores da cena social, sentimentos diversos que se faziam compreender através do olhar sob forma de piedade, incentivo, orgulho, estranhamento, curiosidade: o que faz aqui um grupo de pessoas com deficiência? 
O estranhamento presente nos olhares para o Projeto Andanças traduz um espanto com o inusitado criado pela cena. Muitas diferenças são colocadas em foco e destacadas de uma multidão, a qual somos cotidianamente educados crer que se trata de uma massa homogênea de indivíduos.

Ferreira (2010) assinala que no contemporâneo, a rápida apreensão das coisas tornou imperceptível o insignificante, o detalhe, a sutileza, o instante, como forças criadoras. Para a autora, recuperar a lentidão no presente, através de histórias simples e imagens despretensiosas, constitui-se numa tática subversiva diante de uma estrutura social de poder, que impõem ritmos e modos de ser: escancara a diferença nos atos cotidianos.

\subsubsection{Questões Sobre Diferenças: Alteridade E Identidade}

Pereira (2006) aponta a deficiência como ícone da diferença. E apesar dessa população carregar a marca do "diferente", poucos estudos que remetem simultaneamente aos temas da ALTERIDADE e da deficiência são encontrados. Um levantamento de publicações, do presente trabalho, realizado em novembro de 2009, no acervo da Bireme, utilizando os termos alteridade e deficiência, de forma cruzada, aponta somente seis trabalhos. Destes, três falam sobre pessoas com deficiência. A saber:

- Tese de Doutorado, de Raimundo José Pereira (2006): Anatomia da diferença: uma investigação teórico-descritiva da deficiência à luz do cotidiano; 
- Dissertação de Mestrado, de Gisele Ladik Antunes (2004): A transformação de identidade do portador de deficiência adquirida tardiamente;

- Tese de Doutorado, de Inácia Sátiro Xavier de França (2004): Formas de sociabilidade e instauração da alteridade: vivência das pessoas com necessidades especiais.

Em seu estudo, Pereira (2006) discute a produção de uma identidade fruto da deficiência e registra que na história essas populações não apresentam uma posição social sobre o assunto, assim como elas não afirmam uma identidade cultural de grupo que pudesse ser reconhecida. Estas questões podem ser explicadas pelo histórico social de confinamento em que viviam essas pessoas, que dificultava o contato entre pares e impossibilitava qualquer tipo de articulação. Elas estavam à parte da dinâmica social. Nas últimas décadas, movimentos de lutas das pessoas com deficiência direcionaram-se para uma conscientização social das questões da deficiência. Para este autor, na discussão de identidade a partir da alteridade, a questão da deficiência é poupada ou temida como o mais assustador "Outro", e toma o corpo deficiente como fundamental para uma discussão de identidade a partir da deficiência.

O conceito de identidade, segundo o pensamento de Guattari e Rolnik (1996), remete à ideia de referenciação, de circunscrição a determinados quadros de referência. Discutir uma identidade de pessoa com deficiência implicaria, assim, enquadrar as diferentes deficiências como características fixas (o que parece justificar a dificuldade em realizar tal discussão), ${ }^{20}$ des-

\footnotetext{
${ }^{20}$ Nos casos de deficiência auditiva, entretanto, há estudos como o de Cromack (2004) apontando que as características da linguagem implicam diretamente nas questões da diferença e da identidade cultural, o que suscita pesquisas sobre uma identidade surda.
} 
considerando as relações singulares que cada sujeito estabelece com a situação de deficiência.

O Andanças parece, muitas vezes, ser reconhecido nos passeios que realiza, a partir de uma identidade: um grupo de pessoas com deficiência. Quando presentes, os acompanhantes sem deficiência desaparecem em meio aos participantes, perdem o seu status da normalidade (dado pela ausência da deficiência). Os diferentes modos como aqueles corpos circulam pelo espaço ficam evidenciados acima de tudo.

O corpo deficiente convoca o olhar dos outros, chamando a atenção pela diferença, propondo uma discussão acerca da alteridade. Rocha (1991, p. 185) aponta o corpo deficiente como um desvio da norma, à medida que transgride os padrões específicos de funcionalidade e estética, adequados ao consumo, vigentes a partir do século XX. Infringir as normas predominantes "gera sentimentos discriminatórios em relação ao transgressor e sentimentos de inadequação por parte deste". O preconceito configura um mecanismo de negação social, da carência, falta ou impossibilidades ressaltadas pelas deficiências.

O corpo marcado pela deficiência traz à tona as imperfeições humanas, as fragilidades que se quer negar, entrando em choque com os valores predominantes de culto ao corpo útil e aparentemente saudável, perturbando o contato com as pessoas sem deficiência. Quebra-se, então, a previsibilidade marcante das relações sociais na contemporaneidade, apresentando-se o não saber como lidar com essas pessoas com deficiência. Estas questões constituem o assustador “outro" da deficiência, ao qual remete Pereira (2006). Procura-se, assim, por elementos que deem possibilidade de identificação e, muitas vezes, 
colocam-se os deficientes sob estigmas ${ }^{21}$ constituídos a partir de características do corpo deficiente, como se isto justificasse os comportamentos desses sujeitos, de maneira inflexível, expressos em frases como: "fulano age assim porque é cego". E, muitas vezes, as próprias pessoas com deficiência incorporam representações sociais estigmatizantes, identificando-se com tipificações sociais que as neguem como sujeito (Silva, 2006).

A diferença atribuída às populações com deficiência toma como natural a condição de "pessoa deficiente", desprovendo-as de necessidades cognitivas, de interação social ou de aprendizagem. Há uma sublimação dos sujeitos que justifica o tratamento assistencialista prestado a essas pessoas (Silva, 2006).

Apesar das mudanças históricas e conceituais referentes a estas populações, observa-se na prática uma simultaneidade dos tempos históricos, ${ }^{22} \mathrm{em}$ que diferentes perspectivas teoricoconceituais atravessam os modos de vida, levando a diversas formas de estabelecer as relações sociais. À simultaneidade de diferentes pensamentos e práticas, a vida contemporânea é entrelaçada também por um bombardeamento de modelos idealizados a serem seguidos. "Absorvemos maneiras de viver, sentidos de vida, consumimos toneladas de subjetividade" (Pélbart, 2003, p. 20).

Guattari e Rolnik (1996) afirmam que no mundo contemporâneo, sob a vigência do Capitalismo Mundial Integrado, a constituição subjetiva tende a ser instaurada a partir de processos de individuação que propõem a integração e a normatização dos sujeitos junto a valores socialmente vigentes, que os serializam e individualizam, e a identificação destes sujeitos a modos de ser.

${ }^{21}$ Goffman (1975 apud Rocha, 1991) utiliza o termo estigma como um atributo profundamente depreciativo que torna alguém diferente de outros que se encontram numa categoria e que pode excluí-lo dela. ${ }^{22}$ Para Aníbal Quijano (1988 apud Castro, 2001) o tempo é simultâneo e seqüencial, o que implica na coexistência de tempos diferentes e, assim, na convivência de concepções históricas de diferentes. 
Entretanto, resistindo a essa tendência, é possível observar, segundo os autores, movimentos de protestos contra a "subjetividade capitalística" que buscam afirmar outros modos de ser, outras sensibilidades, outras percepções que não estão dadas pelas normas sociais. A estes movimentos Guattari e Rolnik (1996) chamam de processos de singularização. A partir deste pensamento (e da citação em epígrafe, no subtítulo 2.3.3, do verbete Alteridade), alteridade e identidade apresentam-se como opostos: os processos de individuação conduzem a uma normalização e integração dos sujeitos em sistemas de identificação que modelam modos de ser. Para os autores os processos de singularização são caracterizados por uma automodelização: eles possibilitam que os sujeitos construam seus próprios referenciais ao captar elementos da situação, independente de modelos pré-determinados. Assim, é necessário que se abra espaço para as diversas experiências que compõem o viver, para a alteridade cotidiana.

A relação estabelecida com as pessoas com deficiência tende a conduzir o olhar para processos de singularização. São relações marcadas por diferenças que abalam identidades. Nas palavras de Rolnik (2005) "diferenças que fazem diferença”. Criam uma rugosidade e um inusitado nas relações sociais que desconstroem modos pré-determinados de ser e constroem caminhos para processos de singularização.

Para Batista (2004), o processo de identificação ${ }^{23}$ é fundamental para o estabelecimento das relações sociais, o que possibilita a aproximação entre as pessoas. Dessa forma, quando o sujeito não encontra um traço identificatório

${ }^{23}$ Batista (2004, p.32, 33) parte de uma concepção de identificação a partir da psicanálise e a compreende como "mecanismo pelo qual o indivíduo se constitui, é a primeira forma de laço emocional com outra pessoa (...). O processo de identificação é a base para o homem se estruturar em grupo e no convívio social e é pela identificação que ele seleciona a qual grupo pertencer e de qual participar”. 
experimenta um sentimento de estranheza. Na relação com a deficiência, esta aparece como elemento que contradiz o ideal de ser humano, e a pessoa com deficiência aponta para uma impossibilidade de atingir os ideais de homem proclamados pelo mundo contemporâneo.

Sob as normas sociais vigentes, os processos de singularização configuram-se como estranhos às formações subjetivas no mundo contemporâneo. Freud (1995) aponta a incerteza intelectual como fator essencial na origem do sentimento de estranheza, de forma que o estranho se trata de algo que não se sabe como abordar. Na contemporaneidade aprende-se a lidar com processos de individuação e não de singularização. Em relação às pessoas com deficiência, depara-se com modelos de superação para identificação e normatização, numa tentativa de individuação destas. Entretanto, muitas deficiências ainda escapam às regras da superação e, quando não se identificam com esses modos de ser (como no caso de deficiências mentais graves), abre-se uma brecha que possibilita olhar para outros modos de ser e apontar para a possibilidade de processos de singularização. Quando a brecha é mantida e, junto com esta, o olhar para outros modos de ser, pode-se considerar que o contato com as populações com deficiência favorecem um despertar para a possibilidade e o desejo de experimentar o estranho na relação com outras pessoas, um desejo de vivenciar a alteridade. Caso contrário, o que é mais comum acontecer, essas populações que não encontram modelos de identificação sociais são deixadas à margem.

Castiglioni (2000), em estudo realizado com estudantes de Terapia Ocupacional, observou que os futuros profissionais de saúde abordam a deficiência de forma superficial, desconsiderando as complexidades envolvidas, 
configurando um mecanismo de defesa em relação às pessoas com deficiência física. O contato com a deficiência desencadeia emoções que geram afastamento com medo e repulsa ou aproximação decorrentes de pena ou fascínio (Figueira, 2010).

\subsubsection{Singularidade E Similaridade: Conexões Rompidas Pela VELOCIDADE}

Perceber o ser humano (...) como uma interrogação: tal atitude fecunda um interesse fortíssimo pelo outro. Um interesse pelo outro que, quanto mais nos aproxima de suas singularidades, mais nos reenvia para todos os outros seres do mundo. (Sant'anna, 2001)

Em meio a uma multidão que assiste a um show musical, pessoas em passos lentos e estabanados procuram passagem entre o público para atravessar o espaço do evento. Era o Andanças chegando, com atraso, num dos seus passeios. Lentidões guiadas pela bengala branca do cego que vai à frente e chama aqueles que estão ao redor a olhar para o pequeno grupo de pessoas com deficiência que procura um lugar para se acomodar e apreciar a apresentação.

Junto, ao mesmo grupo, as cadeiras de rodas imprimem um outro ritmo e buscam lentificar o passo para acompanhar o restante do grupo: estar juntos e não deixá-los para trás. Fazer juntos. Participar juntos. É preciso olhar para os outros e construir um ritmo comum: uma velocidade de ações que permite acompanhar uns aos outros, não determinada. Construída. Di- 
ferentes ritmos que compõem uns com os outros, configurando a cena de heterogeneidade. Composição que dialoga com o tempo no contemporâneo.

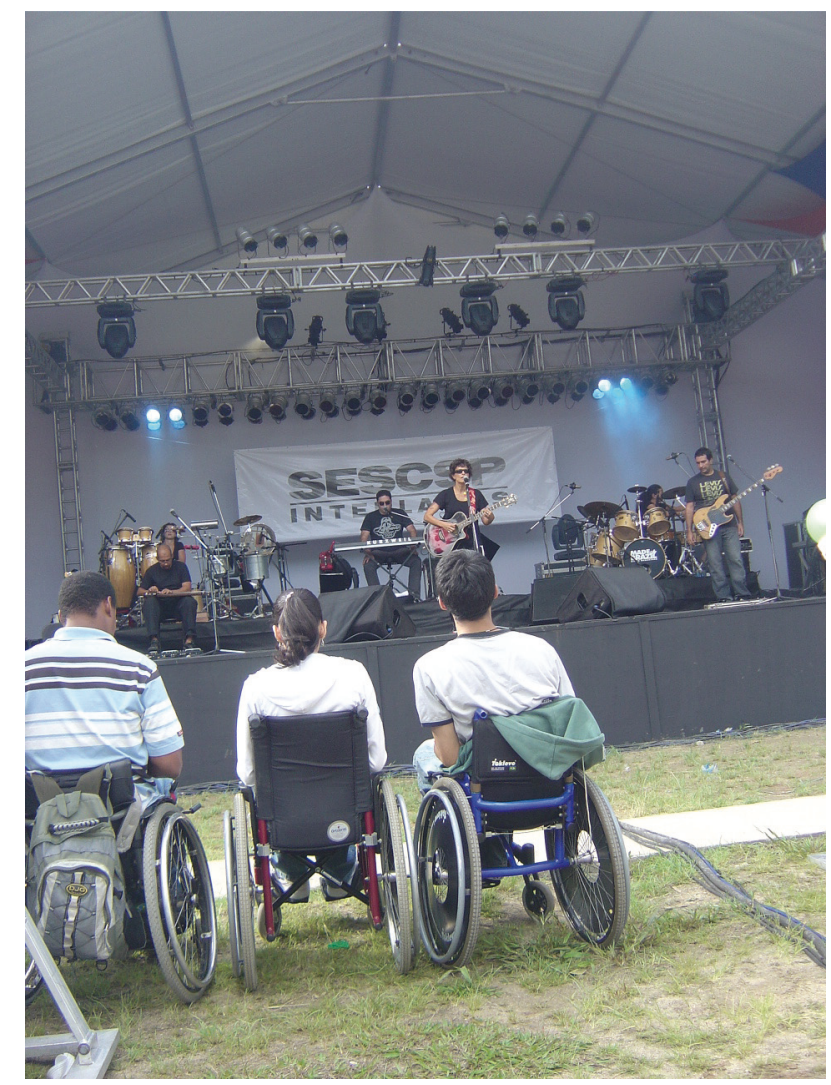

Foto 5 - Participantes do Projeto Andanças no SESC Interlagos, show de Zélia Duncan, em 2008.

Com a inauguração de uma nova percepção com o advento da velocidade, instaurada através do automóvel e do avião no século XIX, a lentidão passa a ser definida pelo contrário da velocidade, pela sua falta, como deficiência (Sant'anna, 2001). Os ritmos sociais são, então, pautados por um tempo que necessita ser utilizado ao máximo, não importando a forma como se dão as experiências. Tempo liso: passar por tudo rapidamente. O que implica elementos que possam favorecer a rapidez. Na deficiência, o tempo é, em geral, 
espesso: se aproxima muito mais da lentidão. As ações e relações estabelecidas por essas populações imprimem ritmos variados de corpos tão diferentes.

Antunes (2009), a partir do pensamento de Elias (1998), relata que a temporalidade é uma categoria constituída histórico-socialmente. Nas sociedades modernas, o tempo tem uma função coercitiva para o desenvolvimento de uma autodisciplina dos sujeitos através dos relógios, calendários e outras formas de regulação do tempo, que são externas ao homem. As inovações tecnológicas e organizacionais tencionam os homens a criar novos modos de gerir o tempo (Antunes, 2009; Padilha, 2000).

Segundo a lógica capitalista, o tempo constitui-se como elemento fundamental do seu funcionamento. É num tempo instituidamente veloz que os processos de individuação, conforme definido por Guattari e Rolnik (1996), acontecem. Modos de ser prontos para que os sujeitos possam se identificar, que não abrem espaços para a percepção das diferenças que constituem a unidade do ser.

Rolnik (2010) diz que a produção de diferenças é de natureza essencial do ser humano. Essas diferenças vividas na coexistência com outros (tudo aquilo exterior a um eu) provocam de maneira irreversível uma ruptura no equilíbrio do ser, desestabilizando o sujeito e exigindo a configuração de um novo modo de ser, sentir, pensar, agir.

A organização da vida cotidiana na contemporaneidade, caracterizada por uma aceleração do tempo, desfavorece um viver as diferenças, e até mesmo percebê-las. Os modos de viver que colocam em xeque uma compartimentalização e uma coerção do tempo - como a deficiência, a loucura, os processos de envelhecimento- foram historicamente segregados e negados enquanto possi- 
bilidades de existência dentro dos padrões socialmente estabelecidos, marcados pela velocidade, abstração e relatividade. Para Sant'anna (2001), esses valores formam um tripé que funda muitas experiências humanas, após o advento do automóvel e do avião, símbolos de condições de sucesso, riqueza e poder.

Couchot (2010), discorrendo sobre a questão da temporalidade na era digital, aponta para a necessidade de se tomar consciência das mudanças na forma de gerir o tempo. Assim, alerta que o problema não consiste numa escolha entre velocidade e lentidão, mas permitir a coexistência das diferentes temporalidades que insistem em marcar presença diante do efêmero.

\subsubsection{Os Homens em Relação: A Alteridade Emerge no Encontro}

Abordar o tema da alteridade remete à relação entre os homens: de um sujeito com os outros. Douek (2009) observa que, para Ricoeur (1990), não é possível falar de sujeito sem a presença do outro, sem pensar em alteridade. A alteridade é polissêmica: o outro não é apenas um outro homem, mas as múltiplas formas de alteridade encontradas no caminho da existência. Assim, mesmo as experiências de passividade constituem-se como experiências de alteridade, pois provêm de fora de si. O caráter de passivo na noção de sujeito pode ser sublinhado, pois implica não apenas em ser sujeito de uma ação (sujeito em atividade), mas também ‘é agido’, o que fica claro na expressão 'estar sujeito a' (1990). Entretanto, Douek (2009) alerta que ao se abordar atividade e passividade é necessário não colocá-las como opostos e considerar a receptividade, modificando o olhar sobre a passividade como receptividade ativa. 
Ao partir do pensamento de Ricouer (1990), para discutir o tema da alteridade, pode-se compreendê-la como implicada nas relações que os sujeitos estabelecem com o mundo e com os outros. Participar das diferentes instâncias da vida implica a experiência da alteridade.

A alteridade é conceito mais restrito que diversidade e mais extenso que diferença. A diversidade pode ser também puramente numérica, não assim a alteridade. Por outro lado, a diferença implica sempre a determinação da diversidade, enquanto a alteridade não a implica. (Abbagnano, 2007)

Batista (2004) assinala que no contato inicial com as pessoas com deficiência, a deficiência aparece como um traço contraidentificatório, um estranho que dificulta a relação, na medida em que se percebe no outro a própria fragilidade e limitação.

Na contemporaneidade somos impelidos a construir um olhar nas relações com as pessoas, de forma que as diferenças pouco apareçam, sempre buscando identificar o que há em comum com o outro. Com o achatamento das diferenças, a alteridade perde a voz. Na relação com as pessoas com deficiência, entretanto, as diferenças chamam a atenção, resistindo ao achatamento. Possibilitam um exercício para o encontro entre sujeitos, convocando o olhar do outro através da diferença. As experiências repetidas constituirão conhecimento tácito e poderão se desdobrar para a relação com outras pessoas (sem deficiência), possibilitando a construção de relações pautadas na alteridade: a emergência dos diferentes modos de ser, das diversas subjetividades na cena social. 


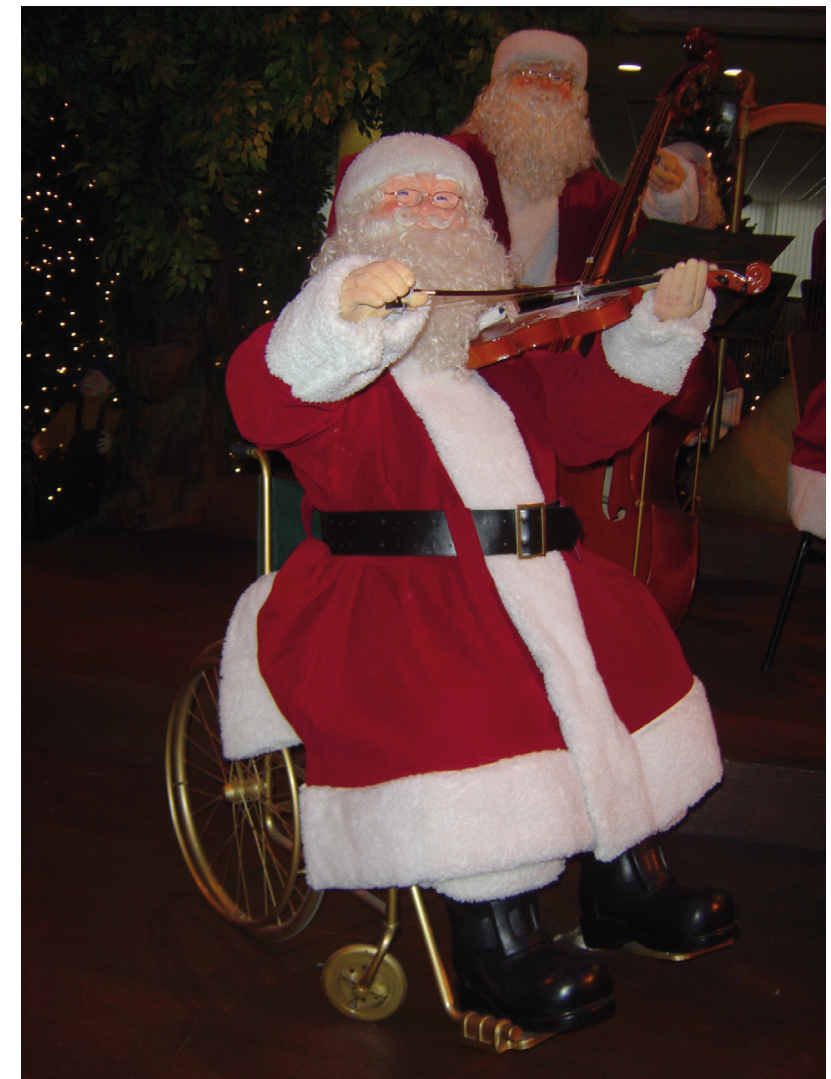

Foto 6 - Imagem de passeio para Casa do Papai Noel (Banco Real), em 2006.

O percurso teórico traçado até aqui, passando por teorias do Lazer, uma interlocução com o campo da Terapia Ocupacional e as discussões sobre participação social e alteridade, constrói uma perspectiva que articula tais elementos e permite a configuração de um novo olhar para as abordagens das deficiências no campo do lazer. É a partir dessa perspectiva que o Estudo de Caso do Projeto Andanças foi elaborado. Apresenta-se, a seguir, o Percurso Metodológico adotado nessa construção. 


\section{Percursos MetODOLÓGiCOS}



Foto 7 - Participante do Projeto Andanças durante passeio ao Centro Cultural São Paulo (CCSP), em 2007, no show do Chico César. Participante deficiente visual conhece o artista através do tato. 


\subsection{O CAMINHO DO PENSAMENTO ${ }^{24}$}

Métodos e instrumentos são caminhos e mediadores para permitir ao pesquisador o aprofundamento de sua pergunta central e de suas perguntas sucessivas, levantadas a partir do encontro com seu objeto empírico ou documental. (Minayo, 2007, p. 300)

Este trabalho é construído a partir do pensamento complexo. Vasconcelos (2002) assinala que as recentes discussões acerca da crise do paradigma científico não produziram ainda sistematizações operativas no domínio metodológico. Portanto, esse percurso constitui-se a partir de tradição metodológica em que se encontra o atual estado das pesquisas sociais brasileiras. Considera-se esta uma pesquisa social, pois utiliza metodologia científica para obter novos conhecimentos no campo da realidade social, o caso específico do grupo estudado, conforme define Gil (1991). Minayo (2007) aponta algumas características da pesquisa social que traduz sua peculiaridade:

- O objeto é histórico: investiga a historicidade humana, respeitando o que é específico da cultura que traz em si. É necessário, entretanto, compreender que há uma simultaneidade de diferentes tempos e culturas que enriquecem a humanidade;

- A sociedade e os indivíduos têm "consciência histórica": ${ }^{25}$ os grupos e a sociedade atribuem significado e intencionalidade ao trabalho intelectual (e não somente o pesquisador), interpretando as ações e

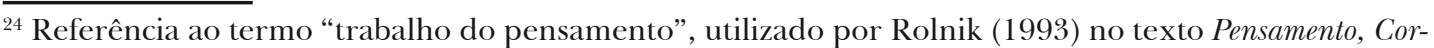
po e Devir: uma perspectiva ético/ estético/ política no trabalho acadêmico.

${ }_{25}$ Minayo (2007) desenvolve o conceito de consciência histórica a partir do pensamento de Goldman (1980), referindo que traz em si a ideia de que a contribuição de determinado ator social ou coletivo deve sempre ser analisada levando em conta o tempo histórico em que viveu, já que o conhecimento e sua prática remetem aos limites das relações sociais de produção concreta.
} 
construções. Assim, tal consciência é projetada no mundo e registrada nos processos de construção do conhecimento acadêmico;

- O objeto é essencialmente qualitativo: o que implica um desafio de manejar ou criar teorias e instrumentos que possam promover a aproximação da diversidade que é a vida humana;

- Trabalha-se a identidade entre sujeito e objetivo da investigação: os colaboradores, por se tratar de seres humanos, têm um substrato comum com o pesquisador (seja por motivo religioso, de classe, idade, cultural ou outro), o que os torna solidariamente imbricados e comprometidos;

- É intrínseca e extrinsecamente ideológica: veiculam-se interesses e visões de mundos historicamente construídos.

Utiliza-se o termo Percurso Metodológico tomando como base o raciocínio de Minayo (2007) acerca da conceituação abrangente de Metodologia: como o debate epistemológico requerido pelo caminho do pensamento do tema de investigação; como a escolha e apresentação dos métodos, técnicas e instrumentos utilizados.

Vasconcelos (2001) sugere que as pesquisas elaboradas sob o paradigma da complexidade optem por estudos mistos quanto à natureza dos dados e de análise, configurando uma pesquisa qualiquantitativa. Neste trabalho, utilizamse dados qualitativos e quantitativos. Os primeiros foram obtidos no contato direto entre pesquisador e situação estudada, buscando retratar a perspectiva dos participantes e enfatizando mais o processo do que o produto, interessando-se em compreender a manifestação do problema nas atividades, nos procedimentos e nas interações cotidianas. Os segundos foram colhidos e or- 
ganizados a partir do estudo dos documentos do Projeto Andanças, fornecendo informações descritivas acerca do grupo estudado, sendo incluídos na escrita sob forma estatística descritiva, como definido por Bogdan e Biklen (1994).

Entre as abordagens qualitativas, elege-se o Estudo de Caso como metodologia de estruturação do trabalho de pesquisa. Este é caracterizado pelo estudo exaustivo e profundo de um ou poucos objetos, permitindo conhecêlos de maneira ampla e detalhada, o que Gil (1991) considera praticamente impossível em outros delineamentos. O mesmo autor esclarece que a análise de uma unidade-caso favorece uma compreensão generalizada do universo do objeto de estudo ou, ao menos, o estabelecimento de bases para uma investigação sistemática e precisa posteriormente.

Lüdke e André (1986, p. 17) assinalam que "quando queremos estudar algo singular, que tenha um valor em si mesmo, devemos escolher o estudo de caso". Para os autores, o Estudo de Caso busca retratar a realidade de maneira completa e profunda. Para isso, utilizam fontes variadas de informação, enfatiza-se a "interpretação em contexto", buscando representar os diferentes pontos de vista presentes. No relato do caso é possível que o leitor identifique aspectos deste, em particular com outras situações vivenciadas por ele, estabelecendo uma "generalização naturalística" ${ }^{26}$

Minayo (2007, p. 164) observa que os Estudos de Caso "utilizam estratégias de investigação qualitativas para mapear, descrever e analisar o contex-

\footnotetext{
26 “Generalização naturalística” é definida por Stake (1978, apud Lüdke e André, 1986, p. 23) como um tipo de generalização que ocorre no campo de ação do sujeito leitor, envolvendo o conhecimento formal, mas também impressões, sensações, intuições, um "conhecimento tácito". "O estudo de caso parte do princípio de que o leitor vá usar esse conhecimento tácito para fazer as generalizações e desenvolver novas idéias, novos significados novas compreensões. Existe também um outro tipo de generalização, que fica mais restrito ao âmbito profissional ou acadêmico, onde diferentes leitores reconhecem as bases comuns de diferentes estudos de caso desenvolvidos em diferentes contextos. A identificação desses aspectos comuns e recorrentes vai permitir, assim, uma ampliação e maior solidez no conhecimento do objeto estudado".
} 
to, as relações e as percepções a respeito da situação, fenômeno ou episódio em questão". Para o estudo do Projeto Andanças, foram realizados os seguintes procedimentos metodológicos: observação participante, registro em diário de campo, estudo de documentos, entrevistas com informantes-chave. Estas ações forneceram dados que foram a analisados da perspectiva qualitativa.

\subsection{Procedimentos Metodológicos}

\subsubsection{Observação Participante}

Segundo Gil (1991), a observação é o uso dos sentidos para obtenção dos conhecimentos necessários para o cotidiano e pode ser utilizada como procedimento científico, pois além de servir ao objetivo formulado, é sistematicamente planejada e registrada. A principal vantagem é a possibilidade de perceber os fatos diretamente, sem intermediação. Entretanto, a presença do observador pode provocar alterações no comportamento dos fenômenos estudados. A observação participante possibilita o acesso de dados que podem ser considerados de domínio mais privados, além da captação de sutilezas e aspectos subjetivos, constituindo uma modalidade complementar ao uso de entrevistas. No papel de observador-como-participante, o pesquisador revela sua identidade e objetivos ao grupo desde o início (Lüdke, André, 1986; Gil, 1991; Vasconcelos, 2001; Minayo, 2007).

Nas atividades do Projeto Andanças, a função de Apoiador possibilita um lugar privilegiado de observação, pois ele tem a possibilidade de construir certo 
afastamento dos participantes com deficiência e seus acompanhantes, intervindo somente nos momentos necessários, de acordo com sua função (auxiliar no acesso dos participantes ao que está sendo apresentado: manejo de pessoas com deficiência física, intérprete de Libras, mediador junto ao deficiente visual, por exemplo), além de acompanhar as relações estabelecidas com os demais integrantes da Equipe de Apoio e dos participantes com os espaços sociais.

Foi sob o caráter de Equipe de Apoio que se deu a participação da pesquisadora no grupo. ${ }^{27}$ Para Gil (1991), o pertencimento do observador ao contexto caracteriza a observação como algo natural. A cada passeio a pesquisadora apresentava-se a cada um dos participantes e seus acompanhantes, com quem entrava em contato pela primeira vez, explicando os aspectos envolvidos na pesquisa: os objetivos, finalidades e procedimentos adotados.

A Equipe de Apoio tem como papel fundamental o da própria observação, como é explicito no relato a seguir:

[...] "O Apoio é muito importante (...). Ele não pode ficar tão próximo, ele tem que chegar mais quando realmente necessita dele. Ele [deve] mais, observar. Porque é o Apoio que são nossos olhos, depois, para a gente ver o que mudou naquela criança. Porque, às vezes, eu estou observando um, que, vamos supor, (...) começou a falar ou ficou feliz com a piada que o outro contou. E ele está observando um outro que não gostou da piada, não entendeu, ficou o tempo todo de cara feia. Então, o Apoio serve pra isso tudo.” (Entrevista no

\footnotetext{
${ }^{27}$ Utilizou-se o termo grupo para nos referir ora a todos os participantes do Projeto Andanças enquanto unidade, ora para nos referir às pequenas unidades que vão para os passeios, que não são constituídas sempre pelas mesmas pessoas e são compostos dos participantes, acompanhantes e Equipe de Apoio. Não fala-se aqui do ponto de vista de teoria de grupos.
} 
No que refere à frequência, duração e periodicidade das observações, foi proposto o acompanhamento de 12 passeios no decorrer de 2008, considerando a realização de uma saída para adultos por mês. ${ }^{28}$ Entretanto, foi possível a realização de seis observações naquele ano. Dessa forma, propusemos a continuidade das observações no ano de 2009, o que não aconteceu, devido a questões administrativas do Município, que não realizou atividades do Projeto até o mês de setembro do mesmo ano. Deu-se, assim, por encerradas as observações para início da organização dos dados coletados. O acompanhamento dos passeios para adultos constituiu uma estratégia de distanciamento das populações com que possuía maior contato, como forma de constituir uma separação entre as atuações como Terapeuta Ocupacional da Prefeitura e como Pesquisadora.

Maturana (2006, p. 126) define o observar como a ação de

[...] distinguir na linguagem os diferentes tipos de entidades que trazemos à mão como objetos de nossas descrições, explicações e reflexões no curso de nossa participação nas diferentes conversações em que estamos envolvidos no decorrer de nossas vidas cotidianas, independentemente do domínio operacional que acontecem.

O acompanhamento e as observações realizadas em cada um dos passeios possibilitou a distinção das situações vivenciadas e das formas de relação estabelecidas (os objetos das descrições, explicações e reflexões que constituíram o estudo de caso e a análise de dados) entre cada um dos participantes com o acompanhante, com a Equipe de Apoio, com o local do passeio, com

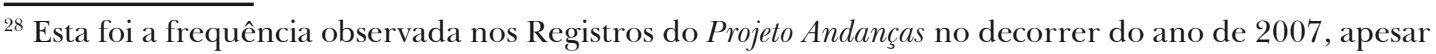
da meta estabelecida de 2 passeios/mês voltados para o público adulto e 2 passeios/mês 'voltados para o público infanto-juvenil. 
as pessoas não pertencentes ao grupo. Compreende-se, aqui, que o campo de pesquisa configura um domínio operacional das ações do pesquisador, e é a partir da participação nestas relações que a observação é possível.

Nos dois primeiros passeios acompanhados, a observação ocorreu de maneira livre, não sistematizada. A partir da terceira saída buscou-se voltar o olhar para as relações estabelecidas entre os participantes do Projeto e entre eles e a comunidade local. Em alguns momentos, a atenção voltou-se para cenas e acontecimentos que traduziam a relação estabelecida e que foram registradas no Diário de Campo para posterior análise.

\subsubsection{Diário De CAMPo}

Um Diário de Campo não fornece tudo da vivência de quem escreveu. É somente um traço. Sendo um instrumento de trabalho que deve se esgotar no relatório final ou no trabalho publicado, é feito de notas, lembrete, desenvolvimento imagens, idéias, experiências, desejos e sonhos, ficando longe dos rigores metodológicos ou teóricos. (Caldas, 2007)

Realizar um Diário de Campo abre à possibilidade da criação de um registro daquilo que é observado na pesquisa de campo, traduzindo o olhar do investigador sobre a situação estudada, complementando os dados colhidos por outros métodos por constituir-se como um outro olhar para o objeto em questão; é possível, na análise de dados, estudar também o olhar do pesquisador. Trata-se de um caderno de notas, onde o investigador anota o que observa, desde as impressões pessoais, resultados de conversas informais, comportamentos contraditórios 
com as falas observadas, entre outros. Constitui um "acervo de impressões e notas sobre as diferenciações entre falas, comportamentos e relações que podem tornar mais verdadeira a pesquisa de campo" (Minayo, 2007, p. 295).

Nos registros das saídas acompanhadas, anotava-se: o local do passeio, o ponto de encontro para a saída, o horário de saída, os integrantes da Equipe de Apoio e os participantes presentes.$^{29}$ Cada um dos passeios foi descrito sob forma de narrativa dos acontecimentos, a partir do olhar da pesquisadora. Em alguns momentos foram realizados também desenhos esquemáticos que auxiliavam na representação e recordação de situações-chave sobre a relação entre o grupo e a comunidade. Também foram registrados os processos de realização e condução das entrevistas.

Magnani (2010), apoiado em Geertz (1983), observa que o caderno de campo situa-se na intersecção de dois momentos constitutivos na relação com o campo de pesquisa: experience-near e experience-distant. A transcrição da experiência traduz uma primeira elaboração da imersão vivida na observação, a ser retomada num momento distante.

\subsubsection{Estudo de Documentos dos Registros do Projeto Andanças}

A partir da idéia de análise documental, propos-se a realização de um estudo dos documentos do Projeto Andanças. A análise documental pode ser considerada uma valiosa técnica de abordagem dos dados qualitativos, comple-

\footnotetext{
${ }^{29}$ Apesar do detalhamento no Diário de Campo, o material utilizado para a Descrição do Campo de Pesquisa foram os registros do próprio Projeto, de forma a manter uma uniformidade em relação aos dados coletados.
} 
mentando informações obtidas por outras técnicas e desvelando novos aspectos. Possibilita a identificação de informações factuais, a partir das questões de interesse (Lüdke e André, 1986). As fontes de documentação foram constituídas de:

- Projeto apresentado ao II Prêmio Chopin Tavares de Lima - Novas Práticas Municipais (PMETRP, 2007);

- Projeto diagramado pelo Centro de Estudos e Pesquisas de Administração Municipal - Fundação Prefeito Faria Lima (CEPAM) para o II Prêmio Chopin Tavares de Lima - Novas Práticas Municipais;

- Registros de participação dos passeios (Anexo A);

- Tabelas de participantes do projeto (modelo disponível no capítulo 5, Quadro 1);

- Fichas de informações dos participantes referentes a cada passeio e autorização do uso de imagem (Anexo B).

Em relação a este material, realizaram-se tratamentos diferentes considerando as distintas informações obtidas a partir de cada um deles. Os projetos referentes ao Andanças foram lidos e forneceram dados específicos sobre a proposta de funcionamento e as ações do trabalho. As fichas de registros, as de informações de cada passeio, junto à autorização do uso de imagem, forneciam um panorama de cada saída. Observou-se, no início, uma preocupação estética com os registros dos passeios, com a inclusão dos ingressos e material de divulgação referente a cada uma das saídas, item que passou a figurar menos nos últimos registros. 
As fichas de participação, juntamente com as tabelas de participantes, forneceram importante material para a seleção dos participantes entrevistados, como será detalhado no item "Entrevista semiestruturada", a seguir. Além disso, possibilitaram um olhar para os movimentos trilhados pelo Projeto, em relação às próprias ações e constituição.

\subsubsection{Entrevista Semiestruturada com Informantes-Chave}

Entrevista semi-estruturada é aquela que parte de certos questionamentos básicos, apoiados em teorias e hipóteses, que interessam à pesquisa e que, em seguida, oferecem amplo campo de interrogativas, junto de novas hipóteses que vão surgindo à medida que recebem as respostas do informante. Desta maneira o informante, seguindo espontaneamente a linha de seu pensamento e de suas experiências dentro do foco principal colocado pelo investigador, começa a participar na elaboração do conteúdo da pesquisa. (Triviños, 1987)

Os questionamentos básicos constituíram, junto à observação participante e ao Diário de Campo, a elaboração de um texto disparador (disponível como Anexo C) para orientar a entrevista, constituindo o foco principal a ser colocado pelo pesquisador ao sujeito entrevistado, de forma a resgatar as experiências vivenciadas nas atividades do Projeto ou no contato com o ele. Ao final do texto, alguns tópicos (roteiro) serviam como guia para a condução das entrevistas.

A entrevista é uma conversa entre duas ou mais pessoas, que acontece por iniciativa do entrevistador, com o objetivo de construir informações refe- 
rentes a um objeto de pesquisa (Minayo, 2007). A modalidade de entrevista proposta pode ser também denominada, segundo Vasconcelos (2001), entrevista focalizada, que se configura com abordagem livre, mas girando em torno de um tema específico.

O que torna o trabalho interacional um instrumento privilegiado de coleta de informações para as Ciências Sociais é a possibilidade que tem a fala de ser reveladora de condições estruturais, de sistemas de valores, normas e símbolos (sendo ela mesma um deles) e, ao mesmo tempo, ter a magia de transmitir, por meio de um porta-voz, as representações grupais, em condições históricas, socioeconômicas e culturais específicas. (Minayo, 2007, p. 204)

As entrevistas semiestruturadas foram realizadas com os diferentes sujeitos envolvidos nas atividades acompanhadas, sendo definidos a partir do conceito de informante-chave: pessoa ou grupo de pessoas que possuem experiências únicas ou percurso profissional relacionado ao assunto avaliado, possui conhecimento sobre os participantes do projeto ou tem acesso a outras informações de interesse do avaliador. Pode ser também alguém que tem um meio de comunicação que representa ou captura a essência do que os participantes falam ou fazem (The National Science Foundation, 2002).

A partir da observação participante, Diário de Campo e estudo de documentos e consequente aprofundamento sobre o objeto estudado, foram identificados e selecionados sujeitos que correspondem ao perfil dos informanteschave entre as diferentes esferas do trabalho: participantes com deficiência ou acompanhantes, Equipe de Apoio, e representantes institucionais que recebe- 
ram o grupo. A amostragem foi selecionada de acordo com as possibilidades de obtenção significativas de informações, constituindo como amostragem não probabilística, pois não apresenta fundamentação matemática.

As entrevistas foram realizadas no local de preferência dos informantes, ${ }^{30}$ em data e horários previamente agendados. Utilizou-se um gravador de áudio com autorização prévia do entrevistado, e o material obtido foi transcrito para posterior análise da perspectiva a ser apresentada mais adiante.

\subsubsection{Seleção Dos Informantes-Chave}

Para a seleção dos informantes-chave, foram divididos os envolvidos no Projeto Andanças em três categorias:

- Configuram o Grupo I: Pessoas que participaram da criação e gestão do Projeto; categoria constituída por funcionários da Prefeitura Municipal de Ribeirão Pires, que participaram do projeto como Equipe de Apoio, na gestão e organização das ações do projeto ou na criação deste. Informantes não vinculados à Prefeitura do município que participaram como Equipe de Apoio, na gestão e organização das ações do projeto ou na criação deste;

- Configuram o Grupo II: Participantes do projeto ou acompanhantes; pessoas com deficiências residentes em Ribeirão Pires que estão cadastradas como participantes do projeto e que já realizaram pas-

\footnotetext{
${ }^{30}$ As entrevistas foram realizadas nas residências, locais de trabalho do entrevistado, ou locais de acesso público.
} 
seios; Familiar, amigo, vizinho ou responsável legal de participante do Projeto Andanças, entre outros, que já realizou passeio com este;

- Configuram o Grupo III: Representantes de instituições que receberam passeios do Projeto em suas unidades.

A seleção dos informantes foi realizada a partir dos dados obtidos com o estudo dos documentos e registros do Projeto Andanças, como também a partir das próprias entrevistas. Os primeiros entrevistados, integrantes da equipe, foram escolhidos pela relevância na constituição e gestão do Andanças, com funções específicas de 2006 a 2008:

- A primeira (Entrevista 1) foi realizada com a então Gerente de Políticas Públicas para Pessoas com Deficiência do município, EHM, uma das criadoras e gestora do Projeto.

- A segunda (Entrevista 2) foi realizada com PACS juntamente com um participante do Projeto, WRC, ${ }^{31}$ outra idealizadora do Andanças, voluntária na GPPPD e presidente do Movimento de Apoio à Pessoa com Deficiência no Município.

- A entrevista seguinte (Entrevista 3) foi realizada com a responsável pela gestão do Projeto, no período de novembro de 2007 a dezembro de 2008, TCAM.

Nestas entrevistas foi possível identificar alguns dos informantes em relação às categorias 1 e 3 . Em relação à categoria 1, os dados das primeiras

\footnotetext{
${ }^{31}$ A entrevista foi inicialmente agendada com PACS e foi realizada conjuntamente por WRC, pelo vínculo entre os dois sujeitos da entrevista (namorados) e pelo segundo também ser participante do Projeto.
} 
entrevistas foram cruzados com os obtidos no estudo dos registros do Projeto, e ainda foram entrevistados:

- RKPS (Entrevista 4), participante da Equipe de Apoio no período de junho de 2006 a agosto de 2007;

- RMM (Entrevista 5), participante da Equipe de Apoio no período de janeiro de 2006 a setembro de 2007 e um dos idealizadores;

- MLS (Entrevista 6) outro criador do Andanças.

Nesta escolha ponderaram-se, não apenas o número de saídas realizadas, mas a disposição dos informantes e a história de participação no Projeto, priorizando entrevistar os sujeitos que podiam assumir várias funções. Em relação à categoria 3, não constam registros de contatos com os locais dos passeios. Estes foram levantados a partir da menção nas entrevistas e levando em consideração os lugares aos quais o grupo foi mais vezes, conforme Tabela 1. Optou-se, assim, por entrevistar representantes institucionais do SESC de São Paulo e do Centro Cultural São Paulo (CCSP). Realizou-se somente uma entrevista desta categoria, pois, até setembro de 2009, encontraram-se dificuldade de agendamento e disponibilidade de um dos informantes, período que culmina com o encerramento da coleta de dados. 
Tabela 1 - Locais visitados pelo Projeto Andanças e número de visitas por ano no período de 2006 a 2008

\begin{tabular}{|c|c|c|c|c|}
\hline Local/Passeio & 2006 & 2007 & 2008 & Total \\
\hline Praia Grande & 1 & 1 & -- & 2 \\
\hline SESC de São Paulo & 5 & 7 & 4 & 16 \\
\hline Teatro Cultura Artística & 1 & -- & -- & 1 \\
\hline Passeios na cidade de Ribeirão Pires & 1 & -- & 1 & 2 \\
\hline Circo Zanni & 2 & -- & -- & 2 \\
\hline MAM/Ibirapuera & 1 & -- & -- & 1 \\
\hline Teatro Alpha & 1 & 2 & -- & 3 \\
\hline SESI Vila Leopoldina & 2 & 1 & -- & 3 \\
\hline Trilha de Jeep & 1 & 1 & 1 & 3 \\
\hline Teatro CCBB & 1 & -- & -- & 1 \\
\hline Passeios na cidade de Santos & 1 & -- & 1 & 2 \\
\hline $\begin{array}{c}\text { Parque da Água Branca/ Casa do Papai } \\
\text { Noel - Banco Real }\end{array}$ & 1 & -- & -- & 1 \\
\hline Teatro Folha & -- & 1 & -- & 1 \\
\hline Teatro Vivo & -- & 3 & -- & 3 \\
\hline Teatro Cenforpe & -- & 1 & -- & 1 \\
\hline Circo Spacial & -- & 1 & -- & 1 \\
\hline Centro Cultural São Paulo & -- & 1 & 4 & 5 \\
\hline Parque das Bicicletas & -- & -- & 1 & 1 \\
\hline Base do Exército de Taubaté & -- & -- & 2 & 2 \\
\hline
\end{tabular}

Nota: Os itens destacados correspondem ao local em que o grupo foi mais vezes.

Os informantes-chave da categoria 2 foram selecionados a partir do estudo dos registros do Projeto Andanças, onde foram identificados participantes que estiveram dez vezes ou mais (Tabela 2) em passeios. Considerou-se na escolha dos informantes, a idade, a participação social e a história de vida, questões levantadas com os responsáveis pelo Projeto. 
Tabela 2 - Participantes que realizaram dez ou mais passeios com o Projeto Andanças no período de 2006 a 2008

\begin{tabular}{c|c|c|c|c|c|c|c}
\hline Participante & Sexo & Idade & Deficiência & $\mathbf{2 0 0 6}$ & $\mathbf{2 0 0 7}$ & $\mathbf{2 0 0 8}$ & Total \\
\hline $6^{\text {iv }}$ & Feminino & Adulto & Motora & 3 & 5 & 2 & 10 \\
\hline $15^{\text {iv }}$ & Feminino & Adulto & PC/cadeirante & 3 & 7 & 2 & 12 \\
\hline $19^{\text {ii }}$ & Masculino & Criança/adolesc. & pc/cadeirante & 8 & 2 & 3 & 13 \\
\hline $39^{\mathrm{i}}$ & Masculino & Adulto & Mental & 12 & 11 & 5 & 28 \\
\hline $44^{\mathrm{i}}$ & Feminino & Adulto & Down & 2 & 5 & 4 & 11 \\
\hline $46^{\mathrm{iv}}$ & Feminino & Adulto & baixa visão & 3 & 4 & 4 & 11 \\
\hline $164^{\mathrm{iii}}$ & Feminino & Criança/adolesc. & pc/cadeirante & 6 & 3 & 5 & 14 \\
\hline $166^{\mathrm{iii}}$ & Feminino & Criança/adolesc. & pc/cadeirante & 8 & 5 & -- & 13 \\
\hline $188^{\mathrm{v}}$ & Feminino & Adulto & Física & 5 & 4 & 2 & 11 \\
\hline $240^{\mathrm{iii}}$ & Masculino & Criança/adolesc. & PC & 6 & 2 & 4 & 12 \\
\hline $244^{\mathrm{ii}}$ & Feminino & Criança/adolesc. & pc/cadeirante & 8 & 4 & -- & 12 \\
\hline $245^{\mathrm{v}}$ & Masculino & Adulto & Física & 2 & 7 & 4 & 13 \\
\hline $249^{\mathrm{i}}$ & Masculino & Criança/adolesc. & Down & 11 & 3 & 5 & 20 \\
\hline
\end{tabular}

Nota: o número na coluna Participante refere à posição na lista do Projeto, esta elaborada em ordem alfabética.

i Refere a possíveis entrevistados, categorizados por adolescentes (entre 12 e 18 anos) com deficiência cognitiva, sem deficiência física e dependentes de responsáveis.

ii Refere a possíveis entrevistados, categorizados por adolescentes (entre 12 e 18 anos) com deficiência física que utilizam cadeira de rodas e dependentes de responsáveis.

iii Refere a possíveis entrevistados, categorizados por crianças (menores de 12 anos) com deficiência física que realizam a marcha com auxílio de dispositivos de apoio (como andadores ou muletas).

iv Refere a possíveis entrevistados, categorizados por adultos (maiores de 18 anos).

${ }^{v}$ Refere a entrevistados selecionados antes da elaboração desta tabela P.A.C.S. e W.R.C. respectivamente, na ordem em que aparecem na tabela.

Após identificação dos participantes que mais realizaram passeios com o Projeto Andanças, foram criadas quatro subcategorias, a partir das características apresentadas pelo subgrupos, nos quais eles foram divididos. Escolheuse, então, de um a dois representantes de cada uma:

- Entre os adolescentes com deficiência cognitiva, sem deficiência física e dependente de responsáveis: participante 249, identificado por WM (Entrevista no 9). 
- Entre os adolescentes com deficiência física que utilizam cadeira de rodas e dependentes de responsáveis: participante 19, identificado por AAC (Entrevista nำ7).

- Entre as crianças com deficiência física que realizam marcha com auxílio de dispositivo de apoio; participante 240, identificado por VFS (Entrevista no 10).

- Entre os adultos: participante 6, identificado por ACN (Entrevista no 8); participante 46, identificado por CGMV (Entrevista no 12).

Na subcategoria referente aos adultos foram escolhidos dois entrevistados, considerando duas condições opostas de independência e autonomia.

Os participantes menores de 18 anos estiveram presentes em toda a entrevista, mas não foram a principal fonte de informação, o que ficou a cargo de seus responsáveis legais.

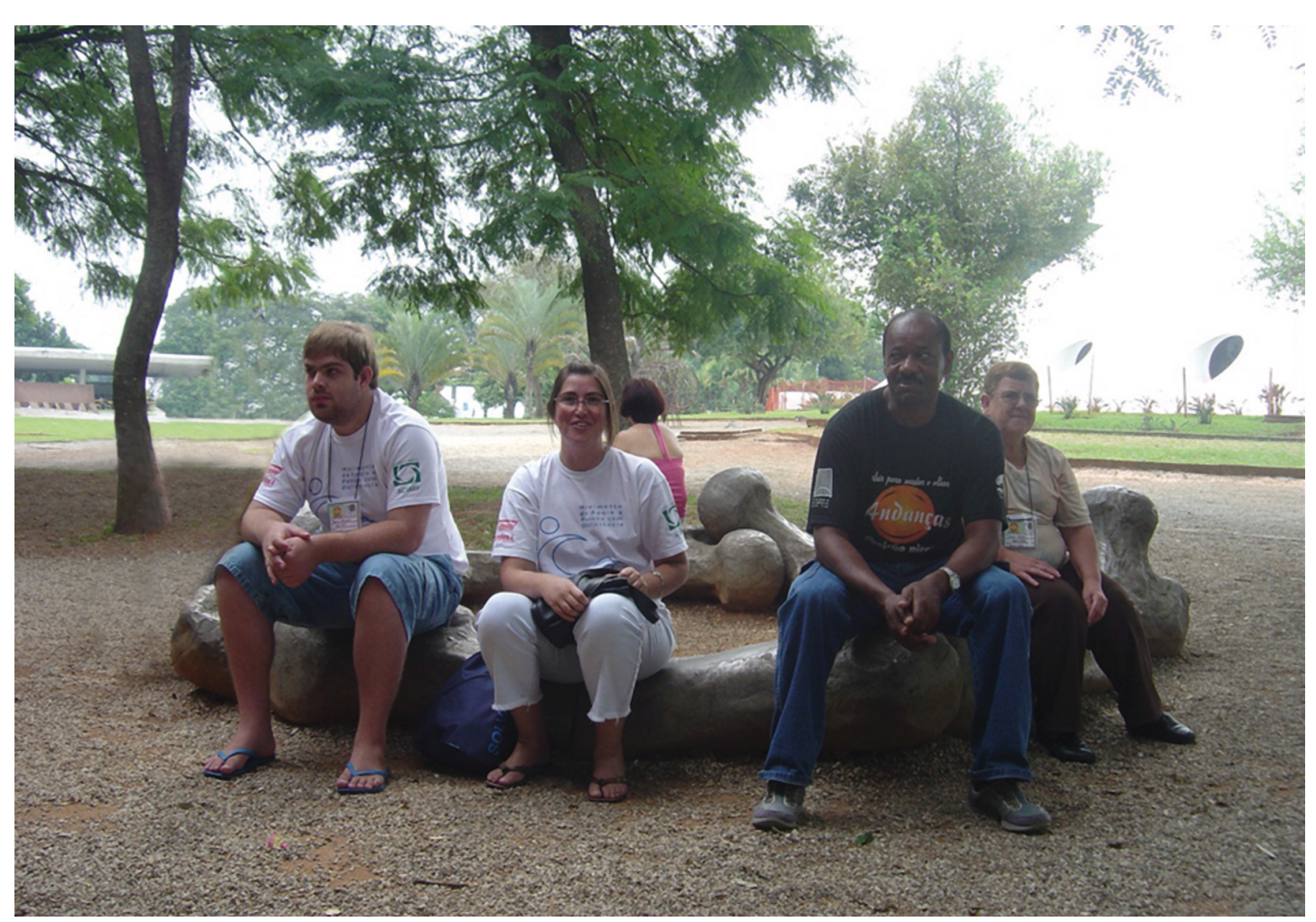

Foto 8 - Participantes e Equipe de Apoio do Projeto Andanças durante passeio ao Parque do Ibirapuera. 
As entrevistas constituem relatos das experiências vividas junto ao trabalho do Projeto Andanças, a partir dos diferentes lugares possíveis: participante, acompanhante, Equipe de Apoio, gestor de espaços culturais ou comunidade. A experiência deste último foi apresentada a partir do olhar dos demais atores, dada a dificuldade em identificar e eleger informante-chave para tal categoria.

Em cada entrevista, os informantes tendem a explicar determinados comportamentos, a partir das perguntas realizadas. Para Maturana (2006), as explicações são proposições de reformulações da experiência.

“Nossa! Maravilhoso! (...) Eu gostaria que este momento nunca acabasse. Porque foi o passeio que deixou o W.M. muito feliz. E a mim também, de acompanhar e conhecer pessoas, conhecer lugares que eu não conhecia”. (Entrevista no 9)

A partir desse olhar, buscou-se dar voz às vivências de cada um dos entrevistados, inserindo trechos das falas dos atores para apresentar o contexto e o próprio Projeto Andanças.

\subsection{Procedimentos éticos}

A autorização para estudo do Projeto Andanças foi concedida pela então gerente da GPPPD (Anexo D). Nos passeios, cada um dos participantes foi esclarecido quanto ao projeto de pesquisa e a presença da pesquisadora para observação de campo. As pessoas convidadas a participar das entrevistas 
foram esclarecidas quanto ao projeto de pesquisa, segundo as orientações da Comissão de Ética para Análise de Projetos de Pesquisa (CAPPesq) da Faculdade de Medicina da Universidade de São Paulo (Anexo E). Aos entrevistados foi apresentado o Termos de Consentimento Livre e Esclarecido (Anexo F), explicado e discutido individualmente, enfatizando a liberdade de escolha na participação ou não da pesquisa, sem qualquer implicação quanto à continuidade de participação no Projeto Andanças.

Para preservar a identidade dos informantes foram utilizadas apenas as iniciais dos nomes, no decorrer de todo o texto.

Para a realização das entrevistas, discutiu-se com o entrevistado sobre a permissão para o registro em áudio. O material coletado nas entrevistas foi transcrito (Anexo G) e devolvido a cada um dos informantes para apreciação e foi utilizado somente após aprovação do material produzido.

As imagens fotográficas que compõem o trabalho tiveram autorização de uso concedida após discussão com os participantes ou responsáveis legais, solicitando a permissão para publicação através da assinatura do Termo de Autorização de Uso de Imagem (Anexo H), no caso de permitirem. Nesta discussão é enfatizada a liberdade de escolha na utilização ou não da imagem.

\subsection{Análise de Dados Qualitativos}

O processo de análise de dados qualitativos, apesar de distinguir-se da etapa de coleta, está estritamente relacionado a esta. Nesta etapa do trabalho os dados obtidos são organizados de forma a fornecer respostas ao problema 
em questão. Segundo Gil (1991), não é possível falar em um esquema rígido de análise, quando se trata de estudo de caso, podendo assumir formas variadas.

No estudo de caso, a análise da unidade-caso selecionada (Projeto Andanças) possibilita compreender a generalidade da questão apresentada, e sua escolha pode ser enquadrada no critério de busca de casos típicos, já que a unidade parece constituir significativamente um tipo ideal da categoria, um evento singular, representação particular da realidade. O Andanças configurase como uma proposta de política pública de inclusão social de pessoas com deficiência que atua em relação aos próprios sujeitos-alvo de seus objetivos e, também, com outros atores do cenário social. O estudo de caso possibilita a coleta de um conjunto de dados que descrevem uma fase ou totalidade da unidade, assim como suas relações internas e fixações culturais (Lancman et al., 2004, Gil, 1991).

Duarte (2002, p. 151) refere que "os métodos qualitativos fornecem dados muito significativos e densos, mas também, muito difíceis de se analisarem”. Por isto, aponta ser necessária a organização e categorização do material coletado, segundo critérios relativamente flexíveis e previamente definidos, de acordo com os objetivos da pesquisa. Após esta etapa, há um "mergulho analítico profundo em textos densos e complexos" (p. 152), para gerar explicações e interpretações que respondam, em alguma medida, às questões da pesquisa. A divisão e classificação do material em categorias teóricas auxiliam a organizar o que se depreende da leitura e interpretação deste.

As entrevistas foram analisadas a partir das diretrizes propostas por Lefevre e Lefevre (2000, 2003), no Discurso do Sujeito Coletivo (DSC), que se 
constitui como uma estratégia metodológica que favorece a análise de discursos verbais, na medida em que possibilita organizar os dados obtidos sob a forma de um discurso coletivo, expressando diretamente a representação social e o conjunto das representações que constitui um dado imaginário e uma dada experiência. Para os autores, as representações sociais são expressão da opinião de determinada população sobre determinado tema, que pode ser manifesto no conjunto de discursos verbais proferidos por pessoas dessa população.

Lefevre e Lefevre (2003) assinalam que, em geral, a opinião coletiva é veiculada indiretamente pelo metadiscurso do pesquisador, sendo os depoimentos considerados de maneira generalizada como eventos meramente individuais, ou por meio de uma fórmula matemática, perdendo o seu caráter discursivo. Assim, o DSC apresenta-se como uma alternativa de expressão do pensamento coletivo.

A construção do DSC utiliza como operadores metodológicos as "expressões-chave", que são trechos literais do discurso de sujeitos individuais e que sinalizam os conteúdos principais das respostas; as "ideias centrais", que dão nome aos sentidos de cada depoimento e de cada categoria de depoimento; e os "discursos do sujeito coletivo", que são os signos compostos pelas categorias e pelo seu conteúdo (Lefevre e Lefevre, 2003).

É importante frisar que os DSCs não são as representações sociais em si, buscando constituir uma camada delas, já que as representações sociais podem ser observadas como camadas sucessivas de discursos. Os DSCs conformam um painel de representações sociais na forma de discurso (Lefevre e Lefevre, 2006). 
O material coletado a partir do Diário de Campo foi categorizado como proposto por Duarte (2002). Aqui, não se utilizou o DSC, por não se tratar de um material resultante de depoimento e sim de observações do campo.

\subsubsection{Os Procedimentos De Análise}

As entrevistas passaram por leituras exaustivas onde foram identificadas as Idéias Centrais dos discursos de cada um dos informantes e separadas as Expressões-chave (os trechos literais dos discursos dos sujeitos), conforme a proposta do DSC. As Idéias Centrais foram definidas de forma empírica, no contato com o material.

No processo de análise do material, a Entrevista noำ1, única representativa do Grupo III, foi desconsiderada pela impossibilidade de construção do DSC para a categoria. Além disso, o pequeno contato do entrevistado com o Projeto Andanças pouco possibilitou que ele abordasse propriamente o tema, discorrendo sobre a participação social de pessoas com deficiência na instituição onde trabalha, o que descaracterizou o objetivo da entrevista.

A partir da leitura do Diário de Campo foi possível emergir temas de análise empíricas, a partir do qual foram destacados trechos sobre o aspecto retratado. Estes fragmentos realizaram uma composição com os DSCs, traços em torno dos quais foi possível construir hipóteses, estudos e reflexões, sendo levantadas novas dúvidas ou reafirmadas convicções. Duarte (2002, p. 152) enfatiza que nesta etapa, assim como nas demais, é necessário que o olhar e a sensibilidade estejam armados pela teoria, "operando conceitos e constructos 
do referencial teórico como se fosse um fio de Ariadne, que orienta a entrada no labirinto e a saída dele".

As categorias emergentes na leitura do Diário de Campo constituíram temas sob os quais foram agrupadas e analisadas as Idéias Centrais que surgiram das entrevistas. Dessa forma, foi possível aproximar os diferentes materiais coletados (o relato do pesquisador e os relatos dos participantes e equipe) na análise realizada.

Assim, apresentam-se, a seguir, o Estudo de Caso (juntamente com a caracterização do campo) e, posteriormente, os resultados e discussões suscitados pela pesquisa proposta. 


\title{
4 CARACTERIZAÇÃO
}

\author{
DO CAMPO \\ De Pesquisa
}

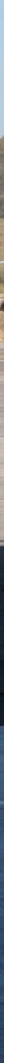

Foto 9 - Participantes do Projeto Andanças observando o pouso de helicóptero na Base do Exército de Taubaté, passeio em 2009. 


\subsection{Estudo de Caso do Projeto Andanças - Incluir Para Mudar o OlHar}

Na perspectiva de construir um estudo de caso do Projeto Andanças - Incluir para mudar o olhar, inicia-se com a caracterização do município e setores onde o Projeto foi criado e desenvolvido, considerando-os fundamentais para compreender as singularidades do caso relatado.

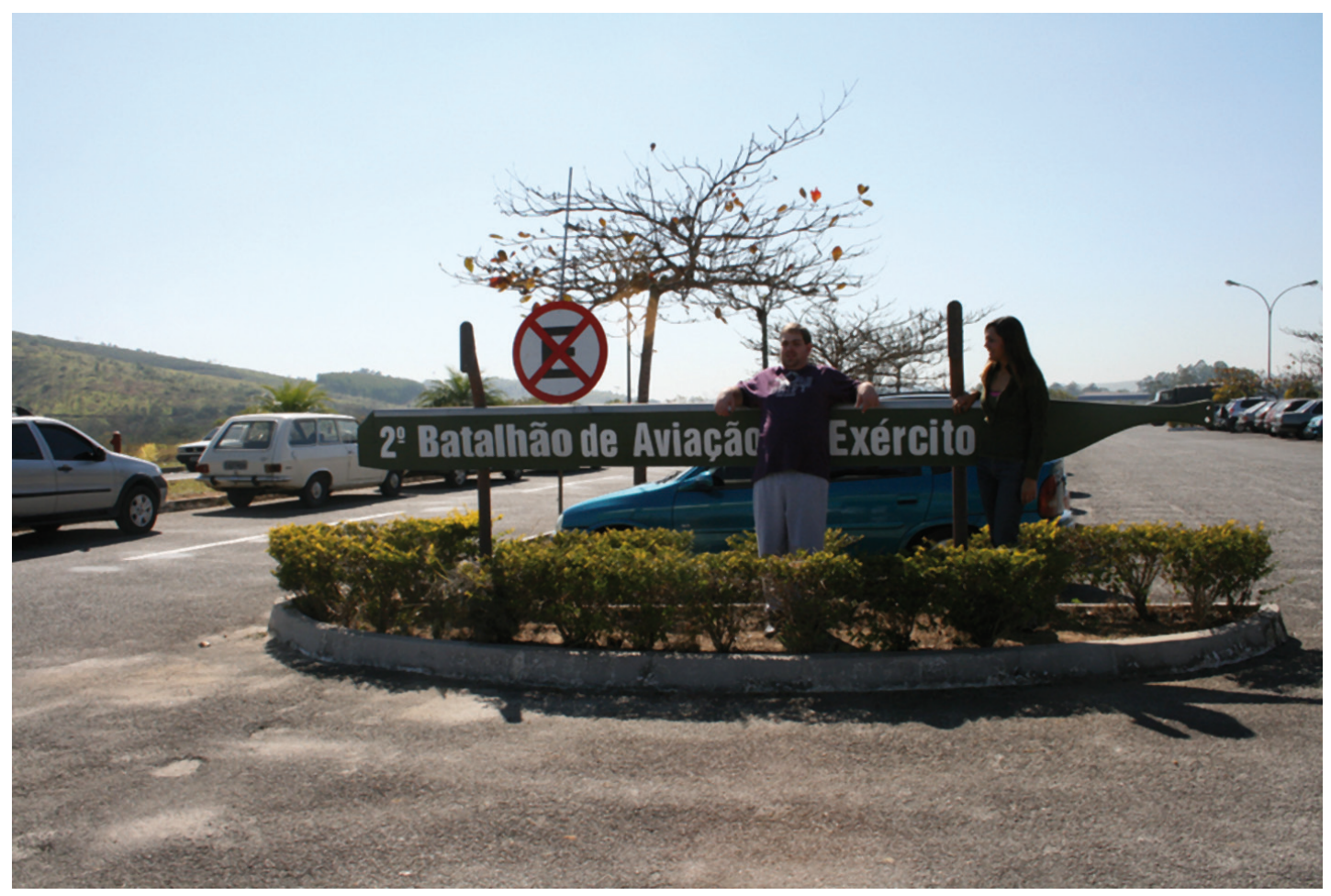

Foto 10 - Participante e Equipe de Apoio do Projeto Andanças em passeio a Base do Exército de Taubaté em 2009.

No ano de 2006, as ações voltadas para as pessoas com deficiência no Município de Ribeirão Pires tinham uma força arrebatadora. Através da Gerência de Políticas Públicas para Pessoas com Deficiência, o governo municipal instaurava naquela cidade um novo olhar para a problemática 
desta população. Não tratava a questão como um problema individual. A administração pública trazia propostas, projetos e intervenções, as quais a população como um todo mostrava o desejo de conhecer e participar. Eventos como a Trilha de Jeep para Pessoa com Deficiência, o Jantar às Cegas e outras ações afetavam todo o município: o sentimento de "fazer junto" se espalhava entre as pessoas.

\subsubsection{O Município de Ribeirão Pires}

Situado a 40 km do Município de São Paulo, a sudeste da Região Metropolitana, a Estância Turística de Ribeirão Pires conta com uma população de 123.791 habitantes, de acordo com os dados do SEADE (2010).

Ribeirão Pires compõe o Grande ABC (Figura 1), região marcada por uma característica industrial, como um dos sete municípios. Sua área urbana fica localizada no vale serrano do ribeirão Pires, num dos braços da represa Billings. Desde 1976 apresenta todo o seu território protegido pela Lei de Proteção aos Mananciais. É constituído por um território acidentado, que faz fronteira com os municípios de Santo André, Mauá e Rio Grande da Serra. (SEADE, 2010; STM, 2010; PMETRP, 2007). 


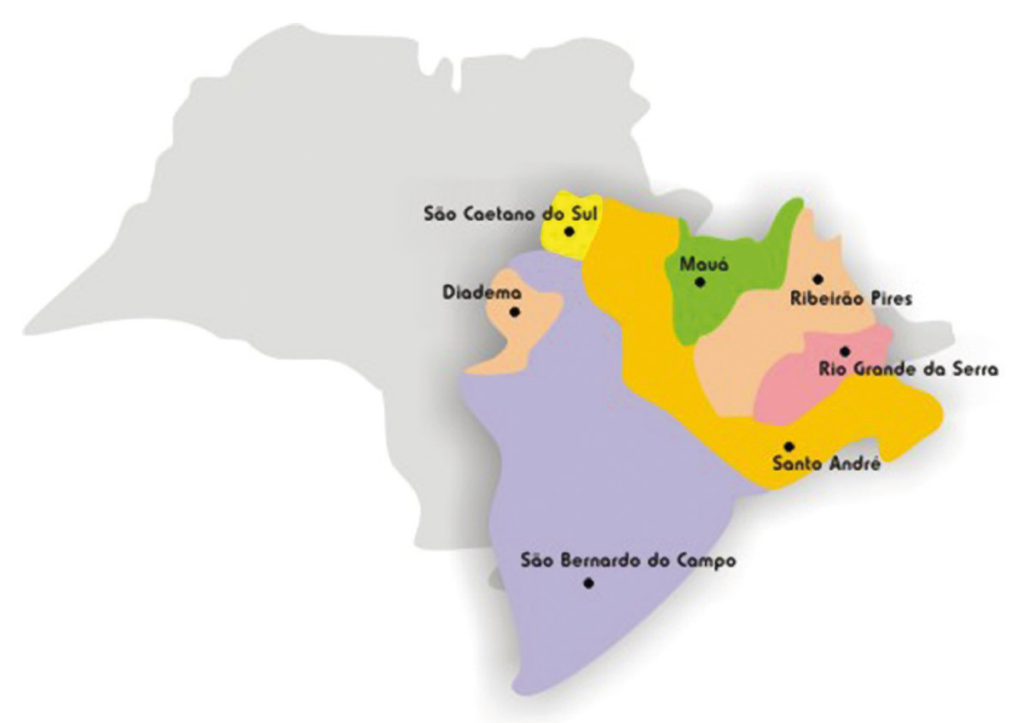

Figura 1 - Mapa do Estado de São Paulo, com destaque para a região do Grande ABC (Fonte: http://ufabcsocial.files.wordpress.com/2008/08/abc-mapa.jpg)

Apesar de 11,88\% de seus domicílios possuírem renda per capita até meio salário mínimo, Ribeirão Pires apresenta um Índice de Desenvolvimento $\mathrm{Hu}-$ mano $(\mathrm{IDH})^{32}$ elevado $(0,807)$. Em relação à situação de vulnerabilidade social, $52,4 \%$ das famílias do município estão expostos a um baixo grau de vulnerabilidade, enquanto 23,1\% à média vulnerabilidade (SEADE, 2010; STM, 2010).

\subsubsection{A População com Deficiência e o Município de Ribeirão Pires}

De acordo com o censo de 2000 do IBGE, cerca de 12.000 habitantes deste município apresenta alguma deficiência. Apesar de não constituir dados oficiais, "é de conhecimento que a grande maioria desta população não tem acesso aos bens culturais comuns; ficam a maior parte do tempo isoladas em

${ }^{32} \mathrm{O}$ IDH é um "índice que mede o grau, em média, de três dimensões básicas de desenvolvimento humano, nomeadamente: uma vida longa e saudável; o nível de conhecimentos adquiridos; e um nível de vida digno". Os indicadores são obtidos a partir do Censo Demográfico do IBGE (Instituto Brasileiro de Geografia Estatística). O IDH, situado entre 0,800 e 0,899 é considerado elevado. (PNUD, 2010; SEADE, 2010). 
suas residências, reforçando a segregação imposta por barreiras físicas ou atitudinais" (PMETRP, 2007, p. 4).

Pelas características geográficas do município, as pessoas com deficiência física se deparam com muitas dificuldades diante dos terrenos acidentados e repletos de ruas íngremes, o que favorece o isolamento desta população, como se pode observar em relato de familiar de pessoa com deficiência realizado durante entrevista:

[...] o lugar que a gente mora (...) é de difícil acesso. Que nem, você veio até aqui, você viu que não é asfaltado. Eu moro no morro, moro numa chácara, com muita dificuldade de sair de casa. (...) eu não tenho transporte próprio... O ônibus daqui não é ônibus adaptado (...). A linha ainda passa ali embaixo. Então eu tenho que descer o morro com cadeira de rodas, subir no ônibus com cadeira de rodas, tudo. Se estiver chovendo eu não tenho condições nem de chegar no portão. É, tudo dificulta a minha vida e a vida do meu filho pra poder sair de casa. Sair de casa já é uma viagem com ele, porque aqui é muito difícil sair. (Entrevista $\mathrm{n}$ o 7$)^{33}$

\subsubsection{Um Novo Olhar Político para a Questão da Deficiência: A GPPPD}

No ano de 2005, foi criado no município a Gerência de Políticas Públicas para Pessoas com Deficiência (GPPP).${ }^{34}$ Com instância administrativa res-

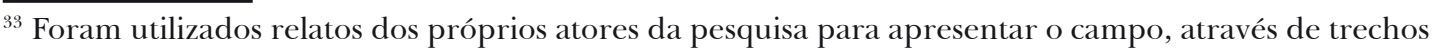
das entrevistas.

34 A GPPPD foi criada em 2005 como Coordenadoria de Políticas Públicas para Pessoas com Deficiência. Tratava-se de uma instância administrativa subordinada à Gerência de Educação. No mesmo ano, a Coordenadoria foi promovida à Gerência, passando a responder diretamente subordinada à Secretaria de Educação e Cultura. Hierarquicamente, as instâncias respondem à Prefeitura Municipal, Secretaria, Gerência e Coordenadoria. No ano de 2009 a prefeitura realizou um remanejamento das instâncias administrativas, passando a GPPPD a constituir parte da Secretaria de Obras e Planejamento Urbano.
} 
ponsável pelas questões das pessoas com deficiência na gestão municipal, tem início uma atuação diversificada, em diferentes áreas, voltada para a referida população. Ações de cunho transversais, ${ }^{35}$ que possibilitam a construção de uma rede de relações ${ }^{36}$ entre as diferentes áreas de atuação que compõem a administração pública.

As ações desenvolvidas pela Gerência (como é comumente referida) visam à participação das pessoas com deficiência, do Município, na vida em comunidade, e que estas possam vivenciar situações diversificadas, das quais muitas vezes são privadas, seja por falta de acessibilidade, informação ou recursos:

- falta de acessibilidade aos espaços coletivos, no que diz respeito às barreiras arquitetônicas e às barreiras atitudinais ou, nas palavras de Sawaia (1999), o "descompromisso político com o sofrimento do outro";

- desconhecimento de seus direitos enquanto cidadão e pessoa com deficiência;

- desinformação quanto à acessibilidade ou não aos espaços;

- desinformação sobre o que acontece nos espaços de cultura e lazer;

- falta de recursos financeiros para custear certas experiências de lazer, seja pelo custo da própria atividade ou pelo custo de chegar ao local, já que muitas das vias de circulação pública também não são acessíveis.

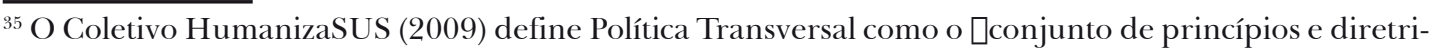
zes que se traduzem em ações construídas intersticial e coletivamente nas diversas práticas e instâncias de efetuação".

36 As ações da GPPPD estão em consonância com o pensamento sistêmico, a partir do qual é desenvolvida esta pesquisa. A idéia de uma rede de relações remete à integralidade de uma unidade e à relação entre suas partes, sua configuração.
} 
A GPPPD implantou ações e serviços municipais importantes no que se refere à população com deficiência:

- o Centro de Apoio à Inclusão Escolar Ricardo Tolesano Mendes, que atende aos alunos com deficiência da rede municipal;

- a Capacitação de Motorista, curso de formação para os funcionários no contato e manejo das pessoas com deficiência;

- o SETA - Serviço de Transporte Adaptado, que realiza o deslocamento das pessoas com deficiência porta a porta, com agendamento prévio;

- o Curso de Extensão Inclusão Escolar e sua evolução Histórica - Revendo conceitos e desenvolvendo ações, em parceria com as Faculdades Integradas de Ribeirão Pires (FIRP) para professores do ensino básico ou fundamental;

- implantação da Comissão Municipal de Acessibilidade, entre outros.

Algumas das atividades desenvolvidas pela GPPPD possibilitam um trabalho junto à população com e sem deficiência, à medida que atuam no imaginário social em relação à pessoa com deficiência. Um trabalho de sensibilizar, de criar condições para que a comunidade seja afetada pelas diferenças que se colocam com as situações de deficiência. São ações que produzem uma mudança na sensibilidade de diversos atores sociais, na forma como as pessoas com deficiência serão vistas pelo território. São Práticas de Sensibilização Territoriais.

No período de julho de 2005 a dezembro de 2008, o Programa Respeite essa Vaga; o Jantar às Cegas; o Passeio de Jeep para Pessoas com Deficiência; e o Projeto Andança favoreceram à população daquela pequena cidade, a possibilidade de construir um novo olhar para as pessoas com deficiência, seus direitos e 
necessidades. Como Práticas de Sensibilização Territoriais, convidavam a apreciar as situações que se colocavam, possibilitando a emergência de outros valores, e as conjunturas afetavam os envolvidos, produzindo percepções, sentimentos e pensamentos novos (Quarentei, 2001).

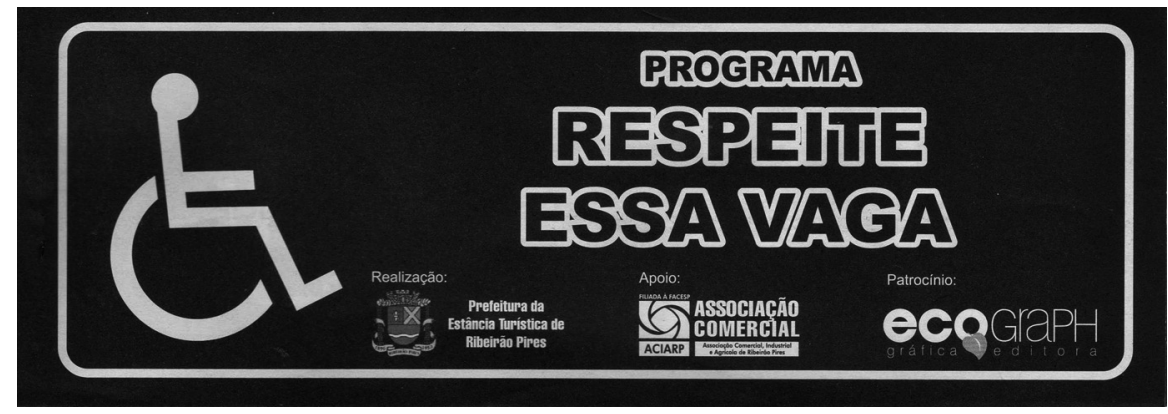

Figura 2 - Capa de talão da campanha do Programa Respeite Essa Vaga.

O Programa Respeite essa Vaga constitui-se como uma intervenção junto à população sem deficiência, para sensibilizá-la em relação às vagas de estacionamento rotativo (Zona Azul) para pessoas com deficiência. Foram entregues explicativos em formatos de talão de zona azul e sacolas, para serem colocados no câmbio dos carros.

“Os relatos das pessoas quando vão usar as vagas é incrível. (...) Então, por exemplo, outro dia a A., que é deficiente também, passava na cidade no final de semana e tinha duas vagas, a cidade tá cheia, porque é próximo do Natal, agora, a cidade cheia, as duas vagas estavam desocupadas. (...) então a gente foi pra rua, nós distribuímos cinco mil sacolinhas de câmbio com bilhetinho explicando o porquê deveria ser, como é que não deveria ser... (...) Então, assim, você vai somando, então a pessoa começa a ver que o deficiente está na rua, que ele tá circulando na rua. Se eu vou parar meu carro na vaga, eu vou pensar: "aquele cara tá na rua, onde é que ele parou, se ele veio de carro." (Entrevista número1) 


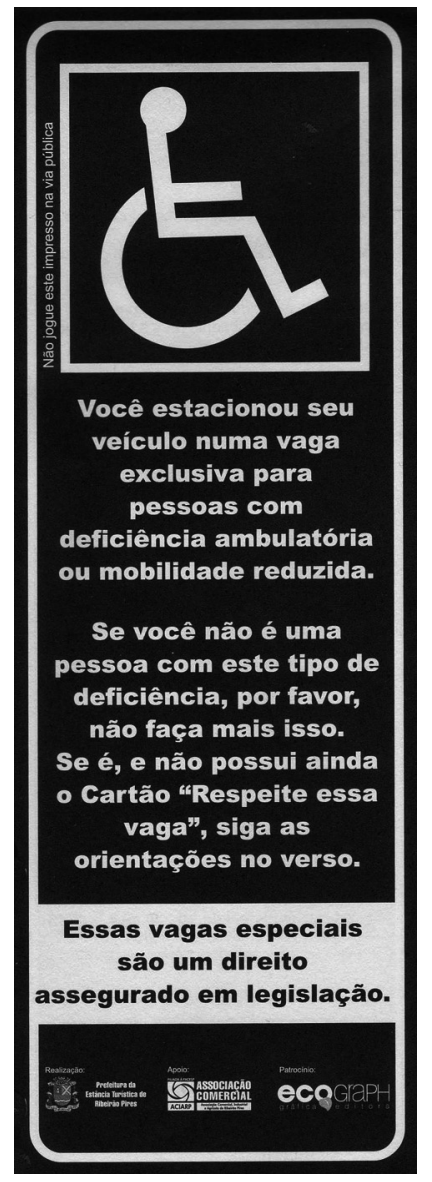

Figura 3 - Talão de campanha do Programa Respeite Essa Vaga.

Como ação micropolítica e em consonância com a proposta macropolítica da legislação estabelecida, a sensibilização realizada favorece a construção de nova percepção acerca da problemática das pessoas com deficiência. Assim, a comunidade afetada favorece as ações de participação, não mais como uma obrigação decorrente da legislação, mas a partir das escolhas e desejos gerados com a sensibilização.

O Jantar às Cegas constituiu-se numa intervenção realizada em 2006, no qual a comunidade foi convidada a vivenciar situação de deficiência visual. Em parceria com um restaurante do município, foi preparado um cardápio especialmente elaborado para a ocasião. Chegando ao local, o público era 
vendado e conduzido até a mesa; realizavam o pedido de bebida e aguardavam o jantar, cujo menu foi mantido em sigilo até a realização do evento. Os participantes deveriam permanecer vendados até o final da refeição, sendo guiados por uma equipe de apoio, caso precisassem sair do lugar.

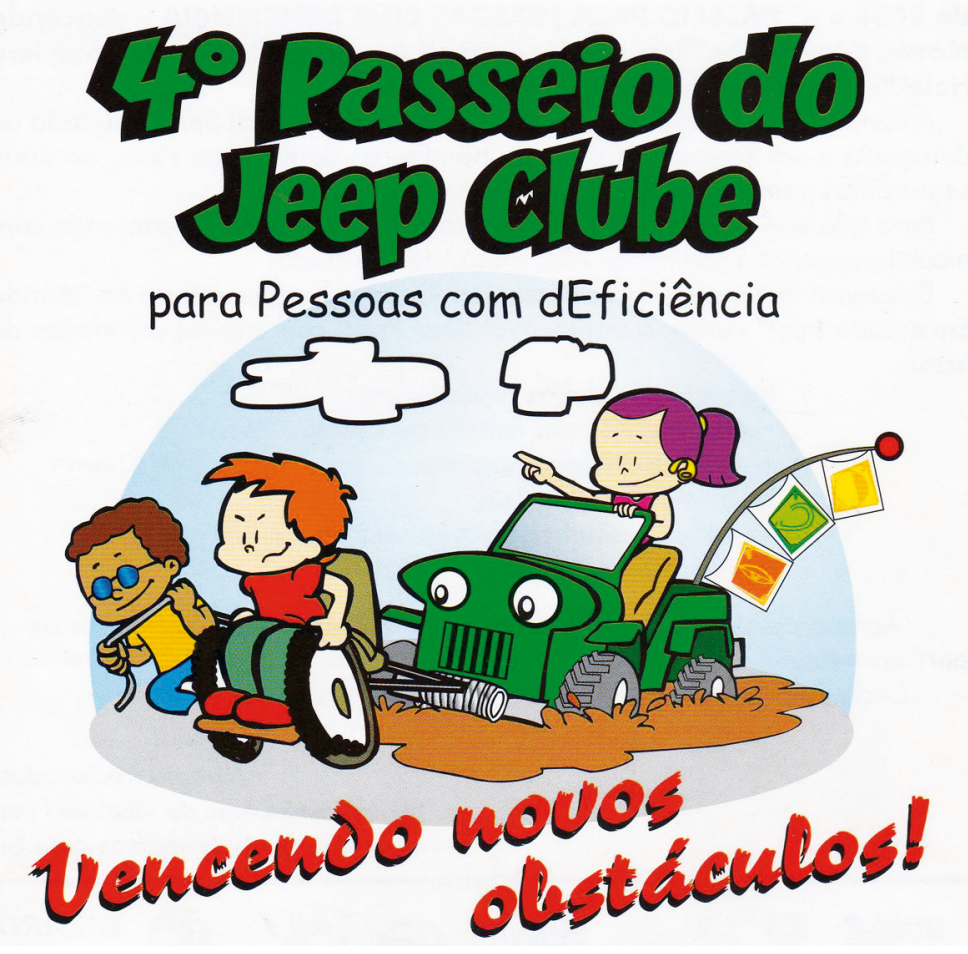

Figura 4 - Estampa da camiseta do 4º Passeio do Jeep Club para Pessoas com dEficiência.

O Passeio de Jeep para Pessoa com dEficiência teve sua primeira edição em 2005 e está ganhando cada vez mais espaço, configurando-se em um evento regional a partir de 2007, com a participação de outros municípios da região do grande ABC de São Paulo. A coordenação do evento define uma trilha a ser percorrida, junto aos membros do Jeep Clube de Ribeirão Pires e autoridades municipais do trânsito, além de um percurso alternativo em caso de chuva forte. "Jeepeiros" de diversas regiões, inclusive de outros estados, são convidados, através de seus clubes (Jeep Club de cada cidade) a participar do evento. No dia 
do passeio, eles comparecem ao ponto de encontro do evento, onde são realizadas vistorias dos veículos e, posteriormente, seguem para o ponto de embarque dos participantes com deficiência, em local próximo à trilha.

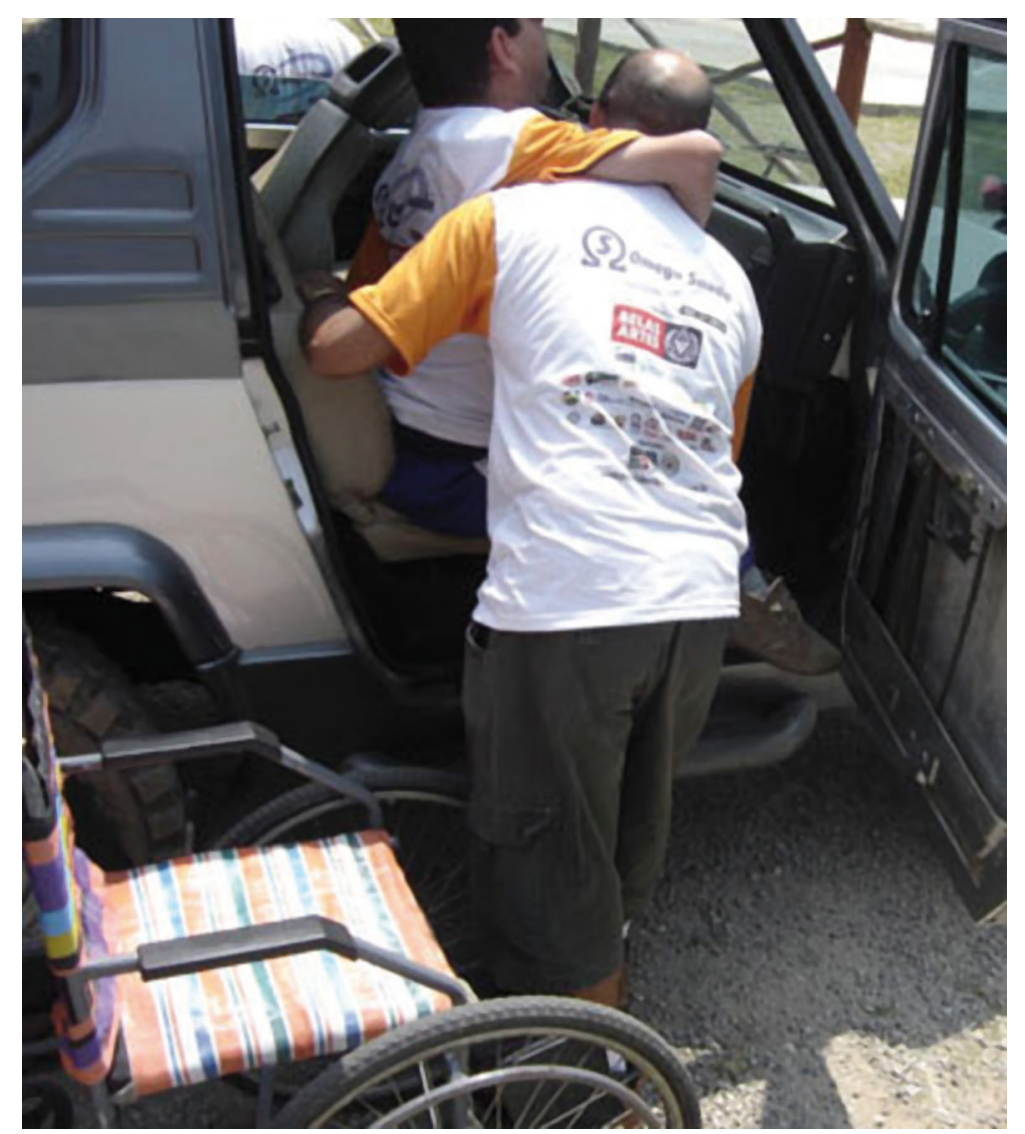

Foto 11 - Imagem do passeio de Jeep realizado em 2007: Participante sendo colocado no veículo.

O comboio de jipes percorre todo o centro da cidade, constituindo uma atração à parte. No embarque, há todo um cuidado com a segurança, sendo que a equipe organizadora se encarrega de observar a necessidade ou não de um cinto de quatro pontos (que oferece maior estabilidade ao passageiro) e oferecer um veículo com tal dispositivo. Os familiares dos "jeepeiros", as pessoas que por ventura desistem de realizar o percurso, aqueles que aguardam a sua vez ou que já realizaram a trilha, participam da confraternização do evento com um churrasco no local. 


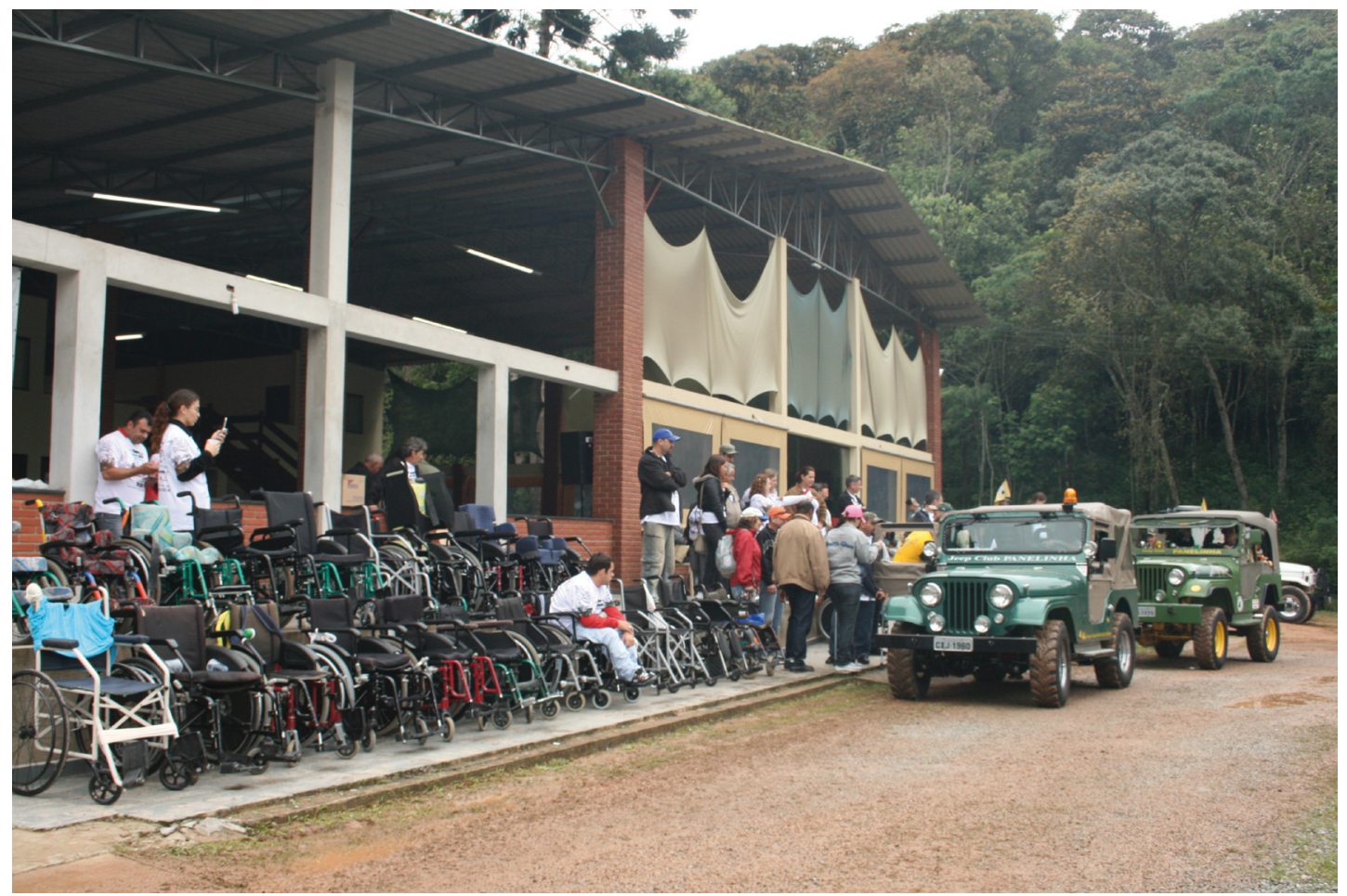

Foto 12 - Imagem do passeio de Jeep, realizado em 2008, momento em que muitos participantes já estavam na trilha e outros ainda eram colocados dentro do jipe.

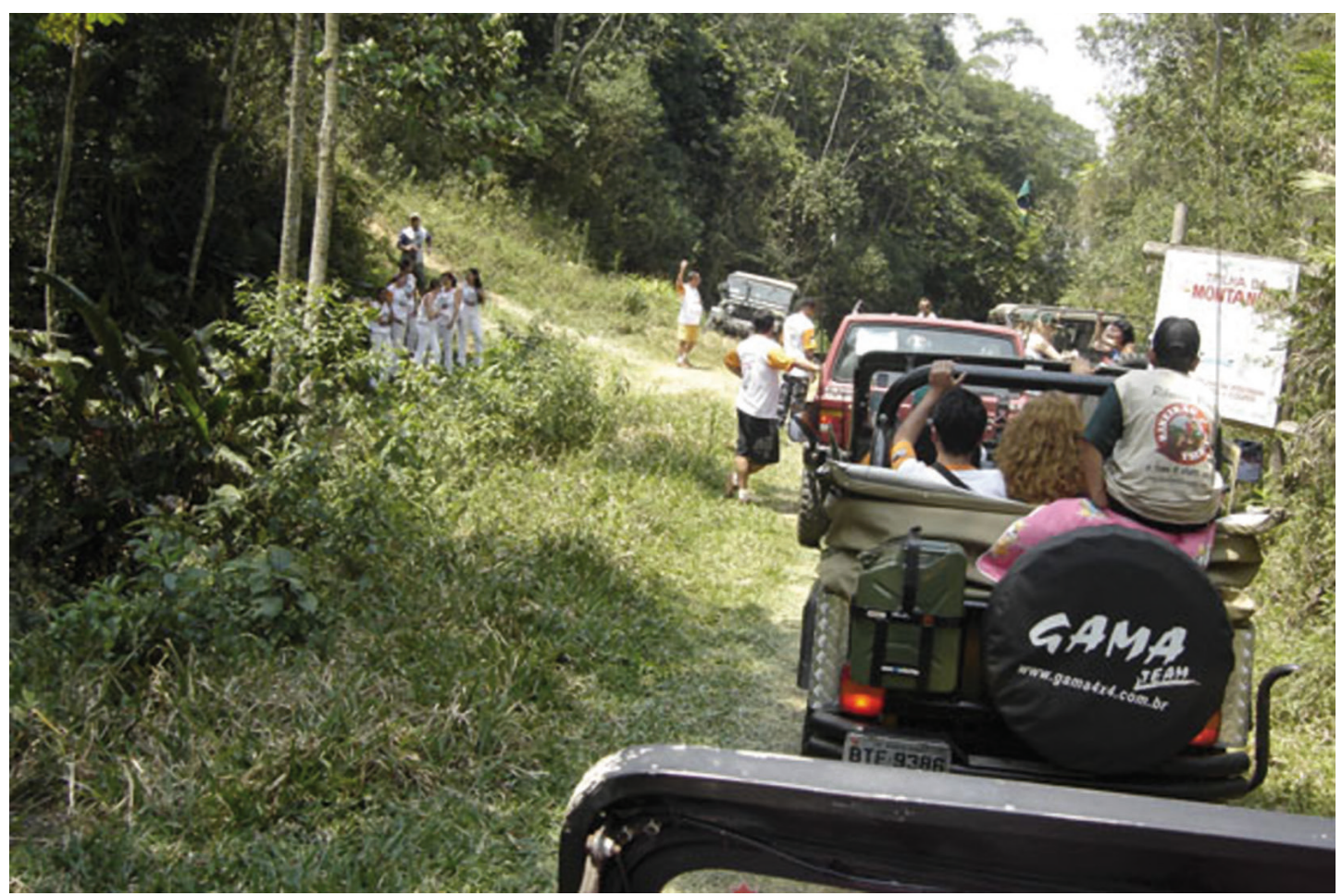

Foto 13 - Imagem do passeio de Jeep, 2007, na trilha realizada. Ao fundo, observa-se uma equipe de auxiliares de enfermagem a postos, no caso de qualquer emergência. 
As experiências instauradas naquele município atingem amplas camadas da população, parecendo contagiar a todos. As pessoas com deficiência passam a ocupar um espaço de preocupação por toda a população local, o que possibilita a instauração de um olhar ético para a diferença. Maturana (2006) assinala que as preocupações éticas independem da razão, surgem no espaço de preocupações com o outro. E isto não se justifica pela razão, mas aceitação do outro. É necessário, então, que as pessoas com deficiência façam parte dos mais diversos domínios sociais, de toda a sociedade. E para que façam parte, é necessário que haja disposição dos sujeitos para a diferença.

Embora estas ações alcancem uma vasta camada da população em geral, ainda são poucas diante do número de deficientes no Brasil. Ressalta-se aqui a necessidade de um amplo trabalho referente à efetiva construção de direitos e às experiências que ampliem as atitudes de respeito às diferenças. Silva (2006) esclarece que a não visibilidade das pessoas com deficiência no domínio das relações sociais remetem ao silêncio sobre elas. Na mídia, as aparições são restritas, e muitas mensagens veiculadas as representam como heróis ou vítimas, e não como cidadãos.

\subsubsection{Locais de Desenvolvimento da Pesquisa}

No acompanhamento dos passeios realizados pelo Projeto Andanças, foram diversos os locais de desenvolvimento desta pesquisa: praia, parque, locais de show. O ponto de encontro e referência para todos (pesquisador, participantes, equipe) localizava-se no período de coleta de dados junto à Ge- 
rência de Políticas Públicas para Pessoas com Deficiência, situada, no período, à Avenida Brasil, 193 - Jardim Itacolomy, Ribeirão Pires, São Paulo. ${ }^{37}$

\subsection{O PROJETO ANDANÇAS - InCLUir PARA MUdAR O OLHAR}

O Projeto Andanças: "Incluir para mudar o olhar" tem início no ano de 2006, com o primeiro passeio para a Praia Grande.

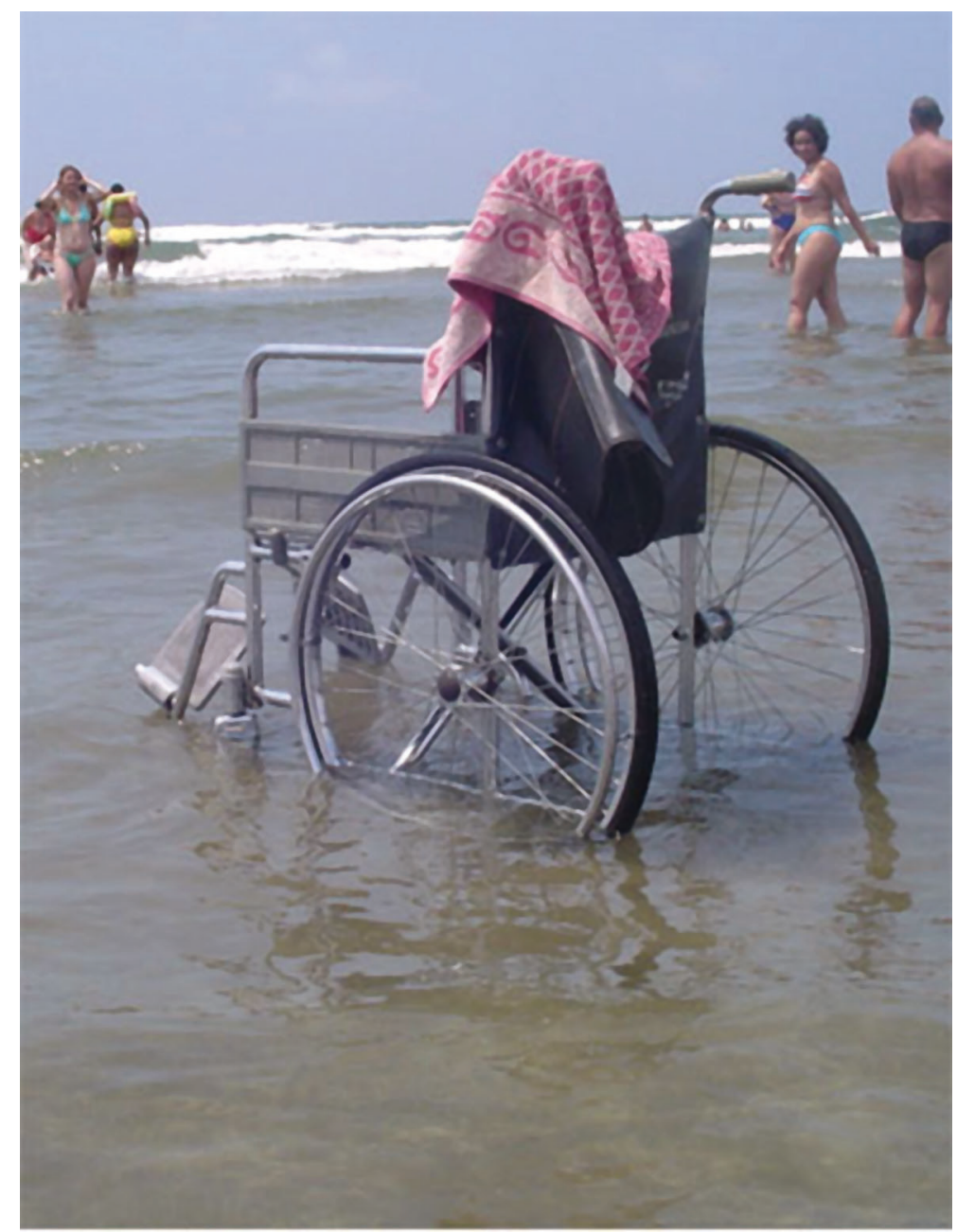

Foto 14 - Cadeira de participante do Projeto Andanças durante o passeio à Praia Grande, em 2006.

\footnotetext{
${ }^{37}$ Desde o ano de 2009, a GPPPD está localizada à Rua Felipe Sabbag, 200 - 2º andar $\square$ Centro, Ribeirão Pires, São Paulo.
} 
Observou-se, no Projeto, que surge uma preocupação ética, que, segundo Maturana (2006), é fundada no espaço de preocupação com o outro, como se pode ver nos relatos a seguir:

“Como surgiu? Foi uma conversa entre eu e o M.L.S.. A gente tinha uma vontade de levar as crianças que a gente transporta. No início era só... A vontade nossa, era só o que a gente conhecia. Que a gente conhecia outras mais, mas não transportava, não tinha tanto contato. Então a gente tinha vontade de levar eles pra praia, porque a gente sabia que a maioria nunca tinha visto o mar. E não só o mar, como nunca tinha ido num parque e coisa e tal. E daí, a gente pegou e fez o comentário. A gente tava saindo de um curso e fez o comentário com a E.H.M., que a gente tinha essa vontade. Ai, ela falou assim: "Isso vira, pode virar um projeto!" (Entrevista no 5)

"Eu sei que a idéia surgiu porque algumas pessoas que trabalhavam na Prefeitura ligadas à pessoa com deficiência faziam festinha de fim de ano, alguma coisa assim e começaram a comentar: "Ah, por que não ir passear, tal?”. E dai, juntando uma idéia com outra, surgiu o Andanças. Acho que houve primeiro um passeio de jïpe, o primeiro passeio de jipe e isso também disparou a vontade de fazer uma coisa mais permanente, na verdade”. (Entrevista no2)

“ A gente fez o passeio de jipe em 2005... E logo no começo de 2006 a gente começou a fazer os Andanças. (..) Tinha uma preocupação, inclusive dos motoristas, do transporte adaptado, de que as crianças e adolescentes que iam, que usam o serviço de transporte adaptado só iam no roteiro casa-escola. Então nunca iam numa festa de aniversário de um amigo e não se encontravam. As mães não se encontravam, as 
crianças não se encontravam. Então eles viam sempre os mesmos rostos. Isso foi uma observação dos motoristas. (...) Então nós sentamos eu, o R.M.M., (...), a P.A.C.S. e começamos a problematizar essa questão. Então dai surgiu a idéia da gente fazer o Andanças que ganhou esse nome porque a idéia é: vai andar que o mundo é grande, então vai ver o mundo e vai ser visto também. E nós começamos a organizar uma estrutura mínima pra que a gente pudesse tirar as pessoas dentro de casa e fazer os passeios.” (Entrevista noำ

Constituído como um projeto de política pública, desenvolvido na Gerência de Políticas Públicas para Pessoas com Deficiência (GPPPD), no Município de Ribeirão Pires, o Andanças tem como objetivo “possibilitar acesso de adultos e crianças com deficiência aos bens culturais comuns, através da oferta de ingressos e transporte aos locais dos eventos" (PMETRP, 2007, p. 4). Através deste Projeto, busca-se a superação de barreiras atitudinais ${ }^{38} \mathrm{e}$ favorecer o empoderamento ${ }^{39}$ dos participantes.

\subsubsection{Os Participantes}

Para participar do Projeto do Andanças é necessário ser pessoa com deficiência, residente no Município de Ribeirão Pires e ter o mínimo de três anos de idade. As crianças e pessoas com comprometimentos considerados

\footnotetext{
${ }^{38}$ As atitudes, que constituem consequências observáveis de costumes, práticas, valores, normas ideologias, crenças religiosas e fatuais, influenciam o comportamento individual e social em todos os níveis. Aquelas que motivam práticas negativas e discriminatórias podem ser consideradas como barreiras atitudinais (OMS, 2003).

${ }^{39}$ Utilizamos o termo definido por Gohn (2004, p. 23), como “processo de mobilizações e práticas destinadas a promover e impulsionar grupos e comunidades - no sentido de seu crescimento, autonomia, melhora gradual e progressiva de suas vidas (material e como seres humanos dotados de uma visão crítica da realidade social)”.
} 
mais graves são acompanhadas por alguém de sua escolha (familiar, amigo, namorado). Em relação aos que possuem maior independência (entre jovens e adultos), não há presença de acompanhante, "como qualquer jovem que sai com seus amigos para um passeio" (PMETRP, 2007, p. 10).

O Projeto não apresenta uma definição de deficiência ou de independência. Assim, o cadastro do munícipe para participação no Projeto dependia da compreensão que os funcionários da GPPPD tinham sobre deficiência e também da sensibilidade para a situação apresentada. É na experiência do sensível, em que as sensações e percepções da relação com o outro podem emergir, no contato com o participante e a família, que essas pessoas são mantidas ou não como participantes. A equipe da GPPPD está atenta para o contexto socioeconômico e para as situações de deficiência relativas à própria família. Como no caso de uma jovem com deficiência auditiva, cujos irmãos com dificuldade de aprendizagem são mantidos como participantes do Projeto, a partir desta categoria, em decorrência do contexto social e familiar.

Em fevereiro de 2009, a lista de participantes contava com $\mathbf{2 4 9}$ pessoas, sendo, em relação à faixa etária, a maior parte composta de crianças e adolescentes (pessoas com menos de 18 anos completos), o que corresponde a $51 \%$, conforme demonstra o Gráfico 1. As pessoas, cuja idade não constava na lista de participantes, foram categorizados como 'Sem Dados'. O cadastro de crianças e adolescentes é realizado a partir de dados do Centro de Apoio à Inclusão Escolar, serviço municipal que atende população com deficiência, especificamente nessa faixa etária. A localização e acesso dessas famílias encontram-se, então, facilitados, o que não ocorre com os adultos, já que não existe um serviço municipal especializado nessa população. 
Gráfico 1 - Participantes do Projeto Andanças distribuídos por idade

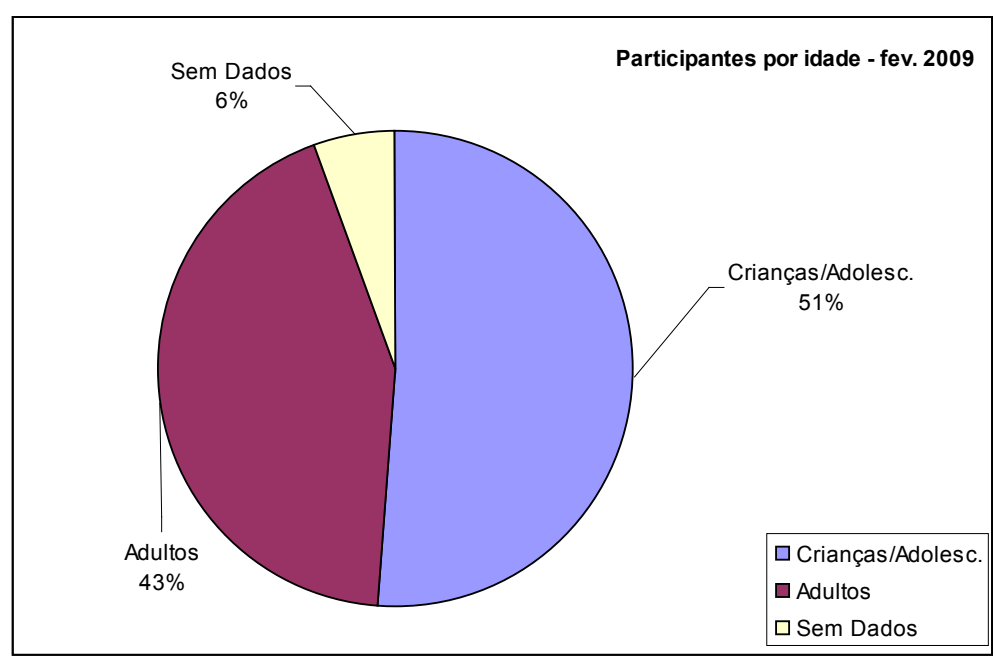

A opção pela idade para caracterizar faixa etária dos participantes requer constante atualização. Assim, com a alteração da equipe da GPPPD em 2007 e 2008, é possível que alguns dados não estejam atualizados.

Em relação à distribuição de participantes quanto ao sexo, observa-se prevalência do masculino, com total de $61 \%$ dos participantes, conforme a distribuição apresentada no Gráfico 2. Segundo Castro et al. (2008), a prevalência populacional de deficiência no sexo masculino é maior nas faixas etárias menor que 12 anos e maior que 60 anos. 
Gráfico 2 - Participantes do Projeto Andanças distribuídos por sexo

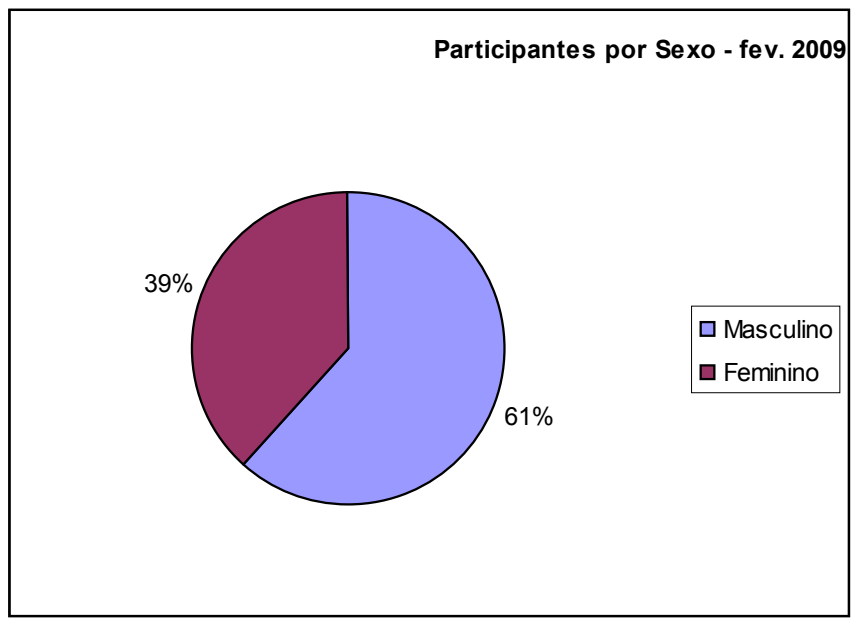

A lista de participantes do Andanças, elaborada pela GPPPD a partir de dados de outros projetos ou do interesse espontâneo de uma pessoa em participar, inclui as seguintes categorias de cadastro:

Quadro 1 - Modelo da lista de participantes do Projeto Andanças (GPPPD, 2006-8)

\begin{tabular}{|l|l|l|l|l|l|l|l|}
\hline & Convidado & Idade & Deficiência & Acompanhante & Endereço & Fone & Observação \\
\hline 1 & & & & & & & \\
\hline
\end{tabular}

Não foi possível a apresentação do perfil a partir da deficiência dos participantes, pois essa informação não é sistematizada no cadastro do Projeto. Além do fato de não utilizarem uma definição de deficiência, o que permitiu a inclusão de pessoas acometidas por situações que, tradicionalmente, não são consideradas deficiência (como aprendizagem), as nomenclaturas usadas não são padronizadas, incluindo termos que referem ao quadro causador da deficiência, nomes de síndromes ou recurso tecnológico utilizado, como: AVC; PC; ${ }^{40}$ Síndrome de Rett; Síndrome de West; e cadeirante.

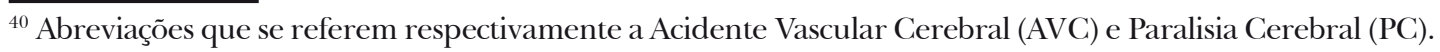




\subsubsection{A EQuipe De Apoio}

Cada uma das saídas é acompanhada por um Grupo de Apoio, ${ }^{41}$ equipe formada por funcionários da Prefeitura de Ribeirão Pires, que atuam na Secretaria de Educação e Cultura ou na Secretaria de Saúde e Higiene, por uma voluntária que faz parte do Movimento de Apoio à Pessoa com Deficiência e funcionários da própria GPPPD. Os profissionais são convidados a participar, não havendo, portanto, obrigatoriedade. A PMETRP (2007, p.13) considera que "este é um momento de capacitação em serviço, pois estes aprendem na prática a lidar com pessoas com deficiência, transferindo este aprendizado para sua prática de trabalho cotidiana”.

A Equipe de Apoio tem como papel o favorecimento da participação das pessoas com deficiência nas atividades e o auxílio no acesso, seja físico ou atitudinal, buscando garantir a compreensão do que está sendo apresentado. Assim, pode auxiliar no manejo de pessoas com deficiência física; como intérprete de LIBRAS; ${ }^{42}$ como mediador para o deficiente visual com descrição verbal; como motorista ou como auxiliar de enfermagem. A participação no Grupo de Apoio implica a assunção do compromisso com a diversão da pessoa com deficiência e não de si próprio (PMETRP, 2007).

\footnotetext{
${ }^{41}$ O Grupo de Apoio é também denominado Equipe de Apoio, ou somente Apoio com letra maiúscula. ${ }^{42}$ LIBRAS: Língua Brasileira de Sinais.
} 


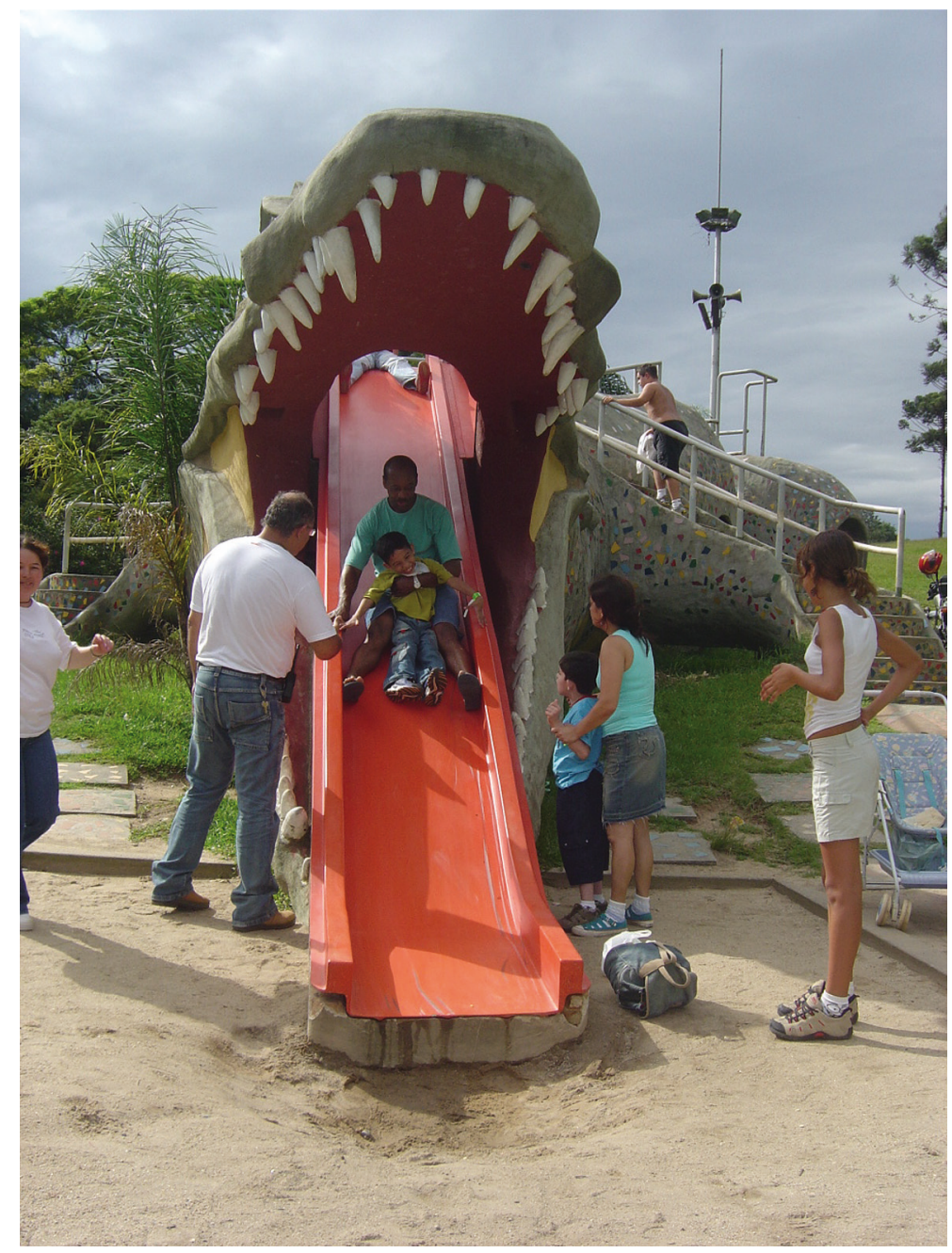

Foto 15 - Imagem de passeio ao SESC Interlagos, em 2006. Integrante da Equipe de Apoio escorrega junto com o participante, favorecendo equilíbrio e segurança à criança.

Desde 2006, a Equipe de Apoio sofreu mudanças em sua composição e número. No início, havia um número maior de pessoas nesta função e também do Apoios em cada passeio. O profissional de enfermagem só aparece até os primeiros passeios realizados em 2007, não constando como Apoio nos posteriores. Este dado pode indicar que a experiência demonstra à GPPPD que a presença de tal profissional não se faz imprescindível.

No ano de 2006, dos quinze passeios que registraram os componentes da Equipe de Apoio, nove contaram com cinco ou mais pessoas nesta função. Ou seja, $60 \%$ dos passeios que registraram o Apoio tiveram no mínimo 
5 apoiadores. Já no ano de 2007, apenas três passeios contaram com esses números, representando apenas aproximadamente $17 \%$ dos passeios (entre aqueles que registraram Equipe de Apoio). Em 2008, esse número cai para apenas dois passeios com o mínimo de cinco acompanhantes, o que representa aproximadamente $15 \%$ dos passeios que constaram registros da Equipe de Apoio. Esses dados podem ser observados, respectivamente, nas Tabelas 3, 4 e 5.

A queda no número de pessoas compondo a Equipe de Apoio pode referir à falta de experiência inicial no trabalho proposto e dos participantes quanto a lidar com as diversas situações dos passeios. O contato entre os Apoios e as pessoas com deficiência nos espaços sociais possibilitou que o grupo ganhasse autonomia nessa circulação. A figura do Apoio passa a ser cada vez menos importante, sendo que na Tabela 5, com os dados referentes a 2008, há uma menor identificação das pessoas que compõem o Grupo de Apoio, sendo que nos dados de alguns passeios constam apenas o número de Apoios.

“Nós montamos um Grupo de Apoio com funcionários da prefeitura (...). Porque no começo, como todo o começo, as famílias são mais inseguras, as próprias pessoas estavam inseguras. Então a gente tinha funcionários, as pessoas se candidatavam, não era "Ah, você é obrigado a ir...", então as pessoas se candidatavam e faziam, parte deste grupo que ajudavam nas transferências do ônibus, pra fora do ônibus, de fora pra dentro, dentro dos teatros e tudo mais. Aos poucos esse grupo foi sendo reduzido por si próprio. Não fazia mais sentido dele ser um grupo grande. Então hoje nas saídas vai uma pessoa da Gerência, que é a TCAM., ${ }^{43}$ que é responsável hoje por este Projeto, vai o motorista e vai um assistente. Então esse assistente

\footnotetext{
$\overline{43}$ TCAM foi responsável pelo Andanças no período de novembro de 2007 a dezembro de 2008.
} 
ajuda muitas vezes a levar ao banheiro, ou se precisa transferir, ajuda a fazer transferência, porque a gente acha teatros com escadas, casas de espetáculo com escadas, tal, mas isso é tranquilo." (Entrevista nํㅜ)

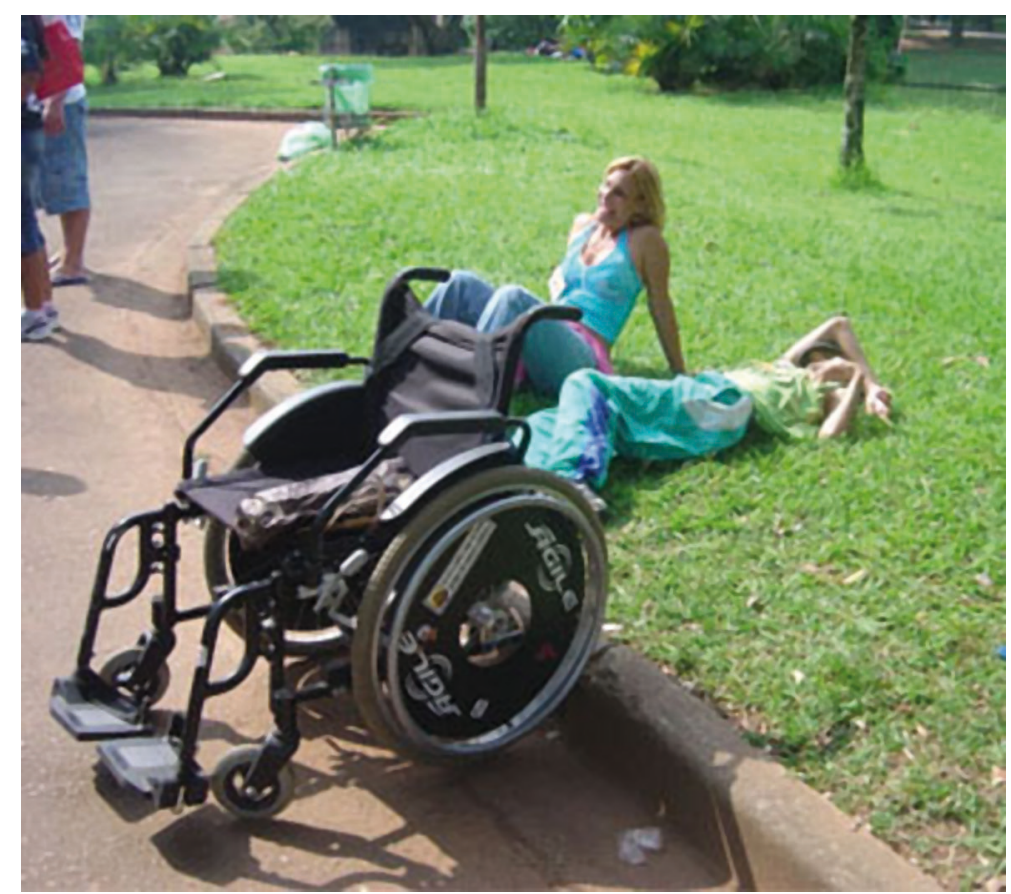

Foto 16 - Participantes do Projeto Andanças em passeio ao Parque do Ibirapuera, em 2006.

Acompanhar as ações dos diferentes participantes e intervir, encontrar, se relacionar com eles deixava de ser uma atribuição da Equipe de Apoio. Pontos da tessitura emergem a partir do desejo de fazer parte e se relacionar. Os familiares, os próprios participantes e os demais envolvidos nos locais interagem mais. Orientam, auxiliam, entram em relação, não por uma função previamente estabelecida, mas por se sentirem convocados a participar da cena que se desenrola. 


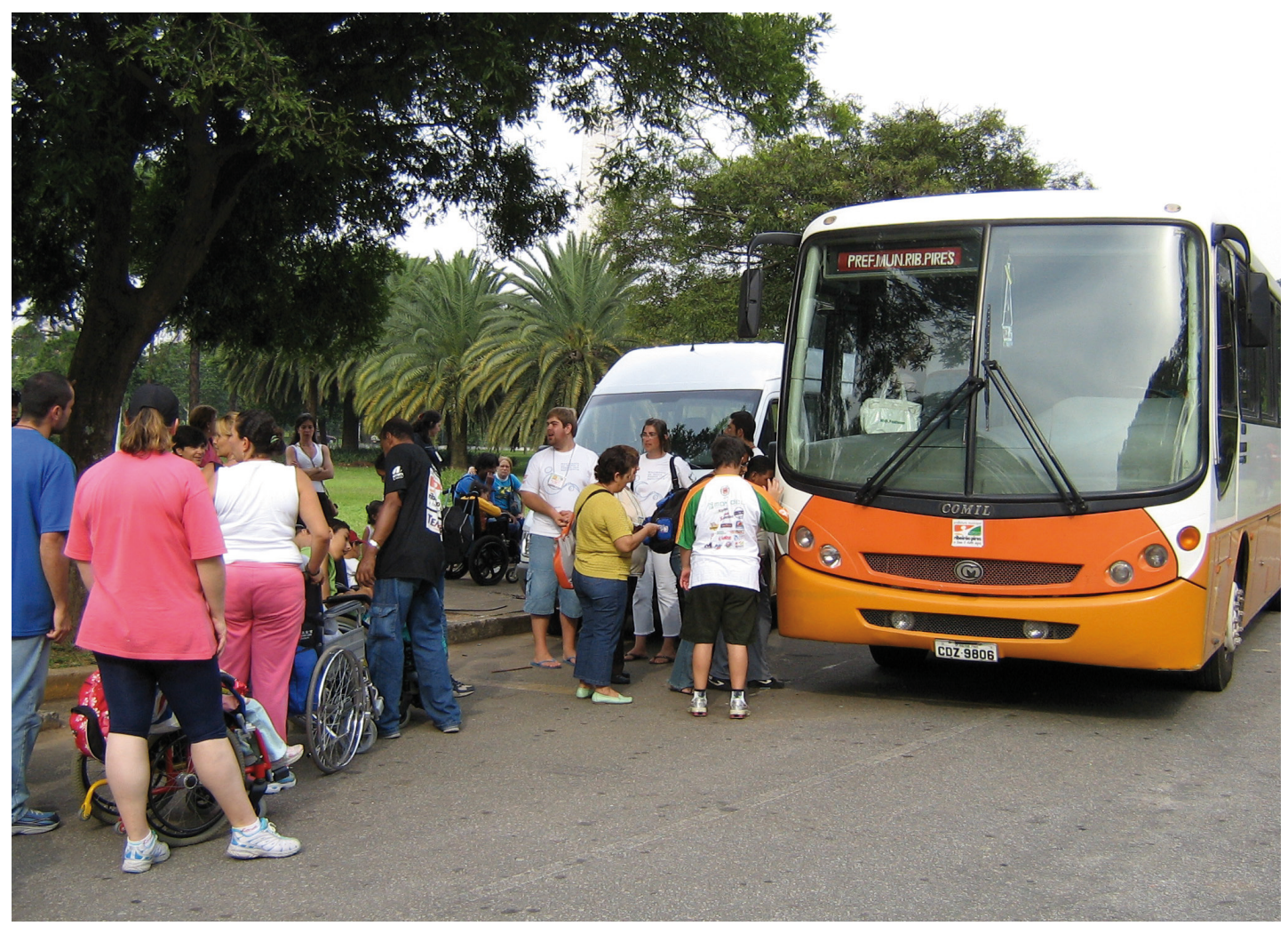

Foto 17 - Participantes e Equipe de Apoio do Projeto Andanças em passeio ao Parque do Ibirapuera, em 2006.

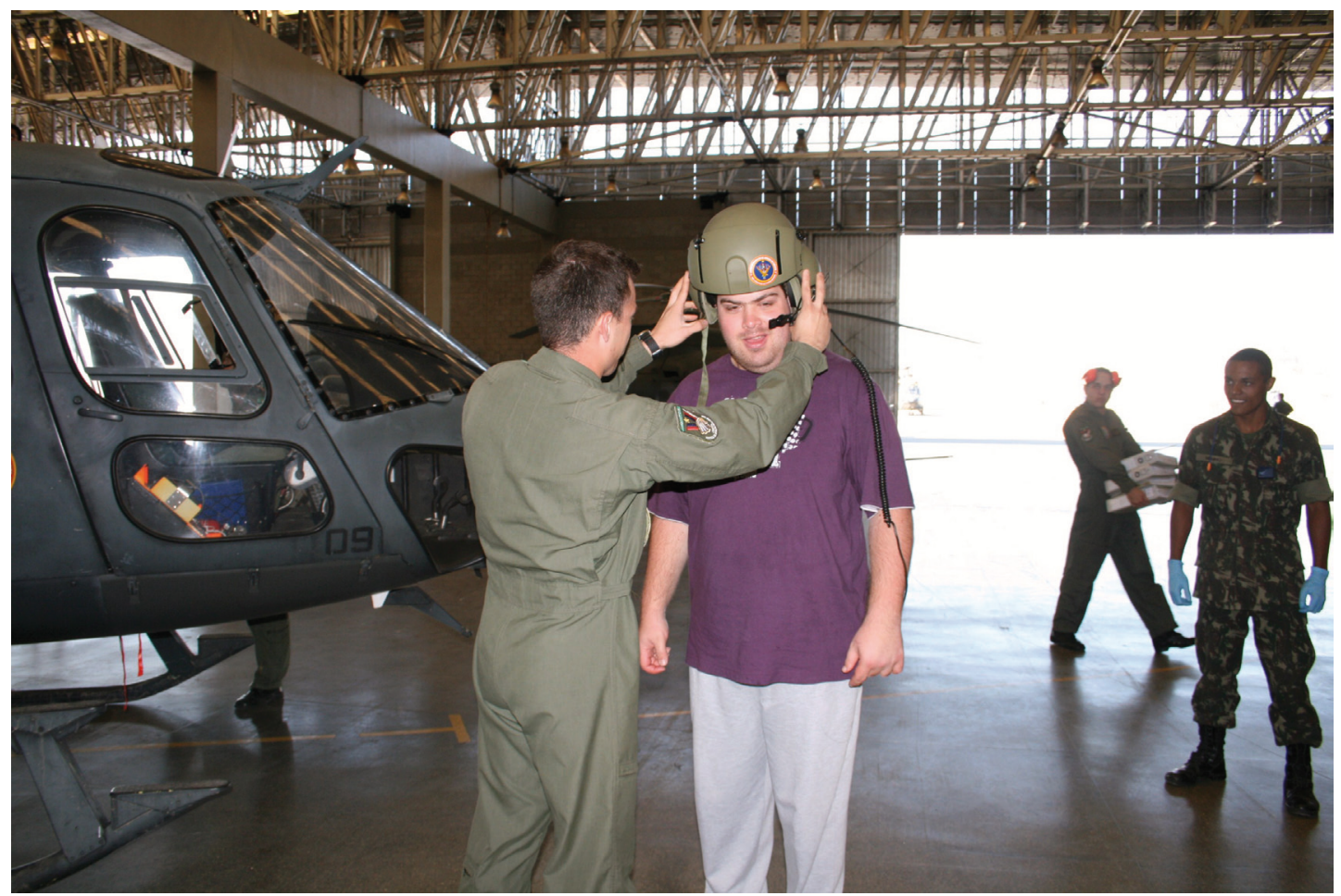

Foto 18 - Participante do Projeto Andanças é orientado por militar da Base do Exército de Taubaté, em passeio realizado em 2009. 
Tabela 3 - Participação da Equipe de Apoio em cada um dos passeios realizados em 2006

\begin{tabular}{|c|c|c|c|c|c|c|c|c|c|c|c|c|c|c|c|c|c|c|c|}
\hline $\begin{array}{l}\text { Apoio / } \\
\text { Passeio }\end{array}$ & $001^{2}$ & 002 & 003 & 004 & 005 & 006 & 007 & 008 & 009 & 010 & 011 & 012 & $013^{2}$ & $014^{2}$ & 015 & 016 & 017 & 018 & Total \\
\hline EHM & & $\mathrm{X}$ & $\mathrm{X}$ & $\mathrm{X}$ & & $\mathrm{X}$ & $\mathrm{X}$ & $\mathrm{X}$ & & $\mathrm{X}$ & & & & & $\mathrm{X}$ & & & & 8 \\
\hline PACS & V/ת & $x$ & $\mathrm{X}$ & & X & X & & X & X & & & $\mathrm{X}$ & $v^{2} / 1.1$ & D & & & & $\mathrm{X}$ & 8 \\
\hline FBS & V/ת & $x$ & $\mathrm{X}$ & $\mathrm{X}$ & & X & & X & X & $\mathrm{X}$ & $\mathrm{X}$ & $\mathrm{X}$ & 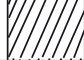 & ג & $x$ & $\mathrm{X}$ & $\mathrm{X}$ & $\mathrm{X}^{3}$ & 13 \\
\hline RMM & 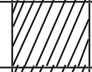 & $x$ & & & & $\mathrm{X}$ & & $\mathrm{X}$ & $\mathrm{X}$ & $\mathrm{X}$ & X & & VID & D. & $x$ & $\mathrm{X}$ & & X & 9 \\
\hline $\mathrm{M}$ & A & $x$ & & & & & & & & & & & 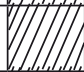 & A & & & & & 1 \\
\hline SPC & Q & & & $\mathrm{X}$ & $\mathrm{X}$ & & $\mathrm{X}$ & & & & & & D & D & & & & & 4 \\
\hline AJL & A & & & & $\mathrm{X}$ & & & & & & & & m & d & & & & & 1 \\
\hline JPF & גת & & & & $\mathrm{X}$ & & & & & & & & 20 & 20 & & & & & 1 \\
\hline $\mathrm{Z}(\mathrm{enf})^{1}$ & ת & & & & & X & & & $\mathrm{X}$ & & & & m & ג & & & & $\mathrm{X}$ & 4 \\
\hline CBS & ה & & & & & X & & & & & & & 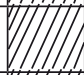 & d & & & & & 1 \\
\hline EFN & ג & & & & & $\mathrm{X}$ & & & & & & & Q & ר & & & & & 1 \\
\hline LAS & ה & & & & & $\mathrm{X}$ & X & & $\mathrm{X}$ & $\mathrm{X}$ & X & $\mathrm{X}$ & Q/1/1/ & גות & & $\mathrm{X}$ & & $\mathrm{X}^{3}$ & 8 \\
\hline RKPS & ת & & & & & X & & & & X & X & $\mathrm{X}$ & 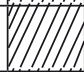 & d & $x$ & X & X & X & 8 \\
\hline ASS & D & & & & & $\mathrm{X}$ & & & & & & & 4 & d & & & & & 1 \\
\hline GSA & A & & & & & & $\mathrm{X}$ & X & & & & & - & Wh & & & & & 2 \\
\hline ZCA & ת/ת & & & & & & & X & $\mathrm{X}$ & & & & V/1/1/ & ת & & & & & 2 \\
\hline AVA & ת & & & & & & & X & & & & & V/ת/ת & ת & & & & & 1 \\
\hline C & A & & & & & & & X & & & & & D/ת & מת & & & & & 1 \\
\hline TBL & ת & & & & & & & X & & & & & V/1/ת & ר & & & & & 1 \\
\hline MLS & גות & & & & & & & & & & & & Q/1/1/ & גית & $x$ & & & & 1 \\
\hline $\mathrm{S}$ & ג & & & & & & & & & & & & (1) & -11 & & X & & & 1 \\
\hline $\mathrm{J} 1$ & ה & & & & & & & & & & & & DI & מת & & & $\mathrm{X}$ & & 1 \\
\hline $\begin{array}{c}\text { Enfer- } \\
\text { magem }^{1}\end{array}$ & $\sqrt{V /} / \int / d$ & $\mathrm{X}$ & & & & & & & & & & & & 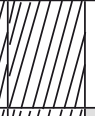 & X & & & & 2 \\
\hline $\begin{array}{c}\text { Total: } \\
\mathbf{2 3}\end{array}$ & VIIIIIAdA & 6 & 3 & 3 & 4 & 10 & 4 & 9 & 6 & 5 & 4 & 6 & & NASA & 6 & 5 & 3 & 5 & \\
\hline
\end{tabular}

Nota: Em 2006 foram realizados 18 passeios. A tabela mostra os profissionais que participaram e em quais dos passeios realizados, o total de participações de cada pessoa como Equipe de Apoio no ano e o total de pessoas na Equipe de Apoio por passeio. Os participantes da Equipe de Apoio cuja menção consta apenas da inicial do primeiro nome não constavam no projeto inicial e não foram contatados para esta pesquisa.

${ }^{1}$ O profissional de enfermagem é o único componente da Equipe de Apoio que é funcionário que presta serviço para Secretaria de Educação, originalmente contratado como funcionário da Secretaria de Saúde do município. Z. é a única auxiliar de enfermagem que é identificada pelo nome. Nos passeios 002 e 015, é registrada a participação de um profissional da saúde, mas não identificado o sujeito.

${ }^{2}$ Não constam no registro do Projeto os componentes da Equipe de Apoio dos passeios: 001, 013 e 014.

${ }^{3}$ No passeio de número 018/2006, foi considerado o total de 5 pessoas na Equipe de Apoio, sendo citado os nomes de L.A.S. e F.B.S. colocados como alternativas, sendo que apenas um dos dois esteve presente. 
Tabela 4 - Participação da Equipe de Apoio em cada um dos passeios realizados em 2007

\begin{tabular}{|c|c|c|c|c|c|c|c|c|c|c|c|c|c|c|c|c|c|c|c|c|}
\hline $\begin{array}{l}\text { Apoio / } \\
\text { Passeio }\end{array}$ & 001 & 002 & 003 & 004 & 005 & 006 & 007 & 008 & 009 & 010 & 011 & 012 & 013 & 014 & 015 & $016^{2}$ & 017 & $018^{2}$ & 019 & Total \\
\hline RMM & $\mathrm{X}$ & X & & & $\mathrm{X}$ & & & & $\mathrm{X}$ & & & & & & & VIIIn & & 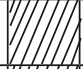 & & 4 \\
\hline $\mathrm{J} 2$ & $\mathrm{X}$ & & & & & & & & & & & & & & & 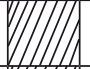 & & 2011 & & 1 \\
\hline $\mathrm{J} \mathrm{P} \mathrm{F}$ & $\mathrm{X}$ & & & & & & & & & & & & & & & D & & - & & 1 \\
\hline LAS & $\mathrm{X}$ & & $\mathrm{X}$ & $\mathrm{X}$ & & $\mathrm{X}$ & $\mathrm{X}$ & & & & & & $\mathrm{X}$ & & $\mathrm{X}$ & 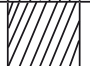 & & 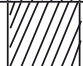 & & 7 \\
\hline FBS & $\mathrm{X}$ & $\mathrm{X}$ & & & X & & & $\mathrm{X}$ & X & $\mathrm{X}$ & $\mathrm{X}$ & $\mathrm{X}$ & & $\mathrm{X}$ & & 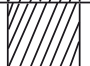 & $\mathrm{x}$ & 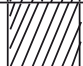 & $x$ & 11 \\
\hline TBL & $\mathrm{X}$ & & & & $\mathrm{X}$ & & & & & & $\mathrm{X}$ & & & & & ג & & - & & 3 \\
\hline RKPS & $\mathrm{X}$ & X & & X & X & X & $\mathrm{X}$ & $\mathrm{X}$ & & & & & & & & 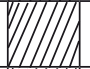 & & 20 & & 7 \\
\hline $\mathrm{Z}(\mathrm{enf})^{1}$ & $\mathrm{X}$ & X & & & & & & & & & & & & & & - & & - & & 2 \\
\hline EHM & & $\mathrm{X}$ & & & & & & & & & & & & & & - ג & & 20 & & 1 \\
\hline $\mathrm{J}$ & & & X & X & & X & $\mathrm{X}$ & & & & & & & & & - & & 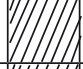 & $x$ & 5 \\
\hline PACS & & & & X & X & X & $\mathrm{X}$ & $\mathrm{X}$ & X & $\mathrm{X}$ & & & X & & & - ג & & - & & 8 \\
\hline EAS & & & & & & & & X & & & & $\mathrm{X}$ & X & $\mathrm{X}$ & $\mathrm{X}$ & VI/ת & $\mathrm{X}$ & $V^{2} / 1 / 1$ & & 6 \\
\hline E1 & & & & & & & & & X & & & & & & & V/1/ת & & V/101 & & 1 \\
\hline C & & & & & & & & & & $\mathrm{X}$ & & & & & & VIת & & 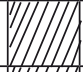 & & 1 \\
\hline G & & & & & & & & & & & X & & & & & D & & - & & 1 \\
\hline TCAM & & & & & & & & & & & $\mathrm{X}$ & $\mathrm{X}$ & & $\mathrm{X}$ & $\mathrm{X}$ & 2/1) & & V/1) & $x$ & 5 \\
\hline $\begin{array}{l}\text { Total: } \\
16\end{array}$ & 8 & 5 & 2 & 4 & 5 & 4 & 4 & 4 & 4 & 3 & 4 & 3 & 3 & 3 & 3 & 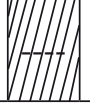 & 2 & WIA & 3 & \\
\hline
\end{tabular}

Nota: Em 2007 foram realizados 19 passeios. A tabela mostra os profissionais que participaram e em quais dos passeios realizados, o total de participações de cada pessoa como Equipe de Apoio no ano, e o total de pessoas na Equipe de Apoio por passeio. Os participantes da Equipe de Apoio cuja menção consta apenas da inicial do primeiro nome não constavam no projeto inicial e não foram contatados para esta pesquisa.

${ }^{1}$ O profissional de enfermagem é o único componente da Equipe de Apoio que é funcionário que presta serviço para Secretaria de Educação, sendo originalmente contratado como funcionário da Secretaria de Saúde do município. Z. é a única auxiliar de enfermagem que é identificada pelo nome.

${ }^{2}$ Não constam no registro do Projeto os componentes da Equipe de Apoio dos passeios: 016 e 018. 
Tabela 5 - Participação da Equipe de Apoio em cada um dos passeios realizados em 2008

\begin{tabular}{|c|c|c|c|c|c|c|c|c|c|c|c|c|c|c|c|}
\hline $\begin{array}{l}\text { Apoio / } \\
\text { Passeio }\end{array}$ & 001 & 002 & 003 & 004 & 005 & $0^{006}{ }^{1}$ & 007 & 008 & $009^{1}$ & $010^{1}$ & $011^{1}$ & 012 & $013^{1}$ & $014^{1}$ & Total \\
\hline TCAM & $\mathrm{X}$ & $\mathrm{X}$ & $\mathrm{X}$ & $\mathrm{X}$ & & Q1510 & $\mathrm{X}$ & $\mathrm{X}$ & 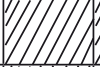 & 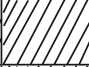 & 111 & $\mathrm{x}$ & VIIID & 2110 & 7 \\
\hline MLS & $\mathrm{X}$ & $\mathrm{X}$ & & & & 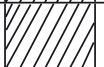 & $\mathrm{X}$ & $\mathrm{x}$ & 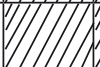 & 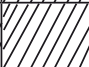 & 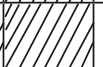 & & -2010 & $x$ & 4 \\
\hline $\mathrm{J} 1$ & $\mathrm{X}$ & & $\mathrm{X}$ & $\mathrm{X}$ & $\mathrm{X}$ & 4111 & & & $4 \pi$ & 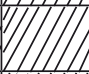 & NID & & 411 & XII & 4 \\
\hline Cinthia & $\mathrm{X}$ & $\mathrm{X}$ & $\mathrm{X}$ & & $\mathrm{X}$ & 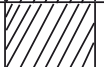 & & & 40 & 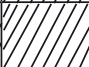 &  & & - 1011 & $x^{2}$ & 6 \\
\hline RMM & $\mathrm{X}$ & & & & & UII & & &  & 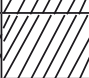 & $x^{21}$ & & Ust & W/1 & 1 \\
\hline FBS & & & $\mathrm{X}$ & & & 0171 & $\mathrm{X}$ & $\mathrm{X}$ & 45 & 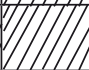 & 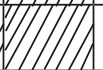 & $x$ & 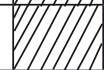 & 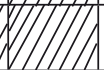 & 4 \\
\hline LAS & & & & $\mathrm{X}$ & $\mathrm{X}$ & 4 & & & 2 & 18 & 1 & & 4 & XII & 2 \\
\hline PACS & & & & & $\mathrm{X}$ & 4 & & & 4 & 4 & 4 & & 4 & 4 & 1 \\
\hline E2 & & & & & & UIII & $\mathrm{X}$ & & 101 & 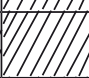 & - & & - & 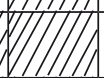 & 1 \\
\hline EHM & & & & & & 01111 & & $\mathrm{X}$ & 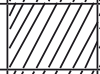 & 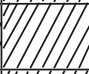 & 111 & & 4111 & 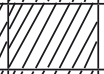 & 1 \\
\hline C & & & & & & 411 & & &  & 1 & DI & $\mathrm{x}$ & UII & WII & 1 \\
\hline $\begin{array}{l}\text { Total: } \\
11\end{array}$ & 5 & 3 & 4 & 3 & 4 & 5 & 4 & 4 & 03 & 04 & 04 & 3 & 02 & ---- & \\
\hline
\end{tabular}

Nota: Em 2008 foram realizados 14 passeios. A tabela mostra os profissionais que participaram e em quais dos passeios realizados, o total de participações de cada pessoa como Equipe de Apoio no ano e o total de pessoas na Equipe de Apoio por passeio. Os participantes da Equipe de Apoio cuja menção consta apenas da inicial do primeiro nome não constavam no projeto inicial e não foram contatados para esta pesquisa. $\mathrm{O}$ único nome não apresentado com iniciais é o da pesquisadora.

${ }^{1}$ Não constam no registro do Projeto os componentes da Equipe de Apoio dos passeios: 006, 009, 010, 011,013 e 014.

2 No que refere à participação da Pesquisadora nos passeios, os registros do Projeto referentes aos passeios 001, 002, 003 e 005 apontavam-na como participante da Equipe de Apoio. No registro do passeio 008, não há menção à presença da pesquisadora. $\mathrm{O}$ dado foi acrescido a partir dos registros em diário de campo, assim como a observação realizada no passeio 014, cujo Projeto não possui registro referente à Equipe de Apoio.

O número de pessoas na Equipe de Apoio não possui correlação direta com o número de participantes e acompanhantes, o que é possível observar nos Gráficos 3, 4 e 5, a seguir. A relação numérica entre Equipe de Apoio, participantes e acompanhantes, em cada passeio, depende também da experiência construída no decorrer das vivências. No período de três anos estudados, observou-se que o número de participantes da Equipe de Apoio diminui gradativamente, não ultrapassando cinco componentes por passeio em 2008. 
Gráfico 3 - Relação entre Apoios, Participantes e Acompanhantes nos passeios realizados em 2006

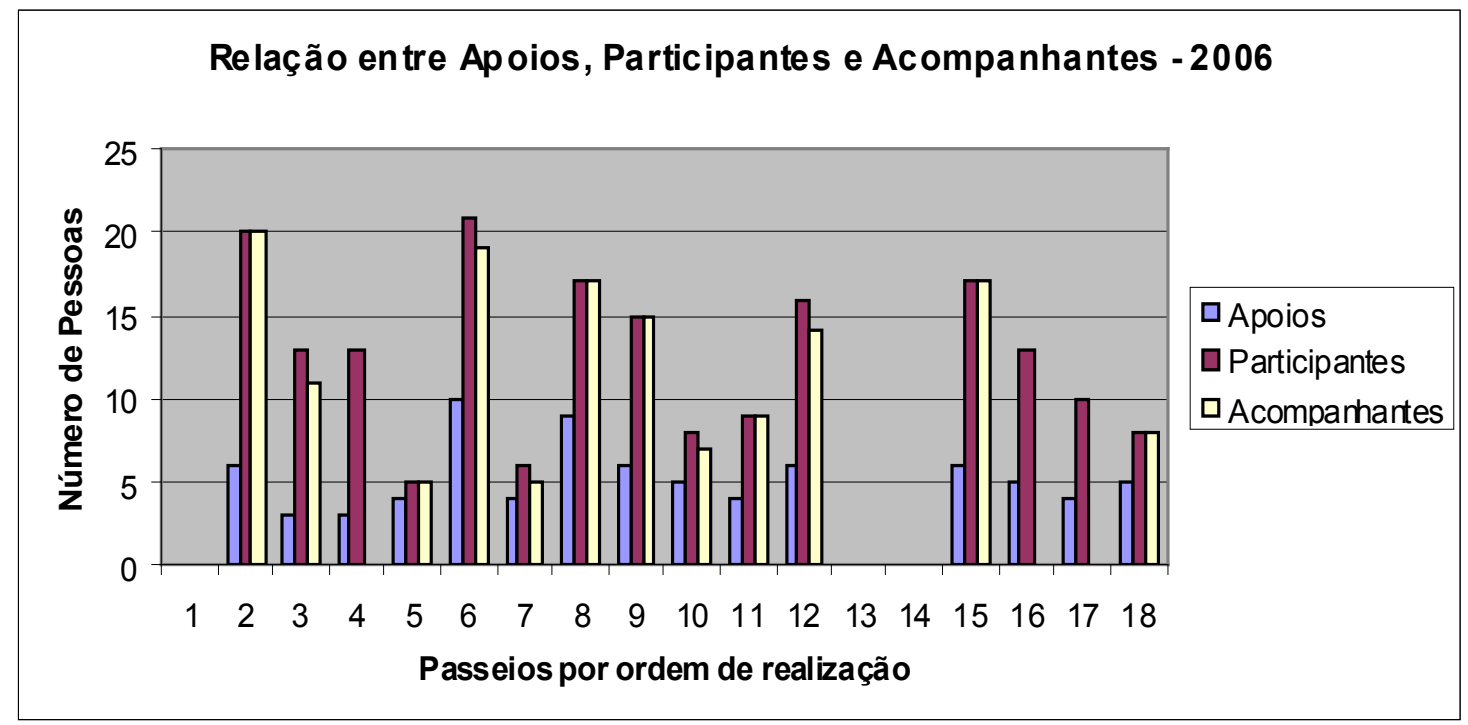

Gráfico 4 - Relação entre Apoios, Participantes e Acompanhantes nos passeios realizados em 2007

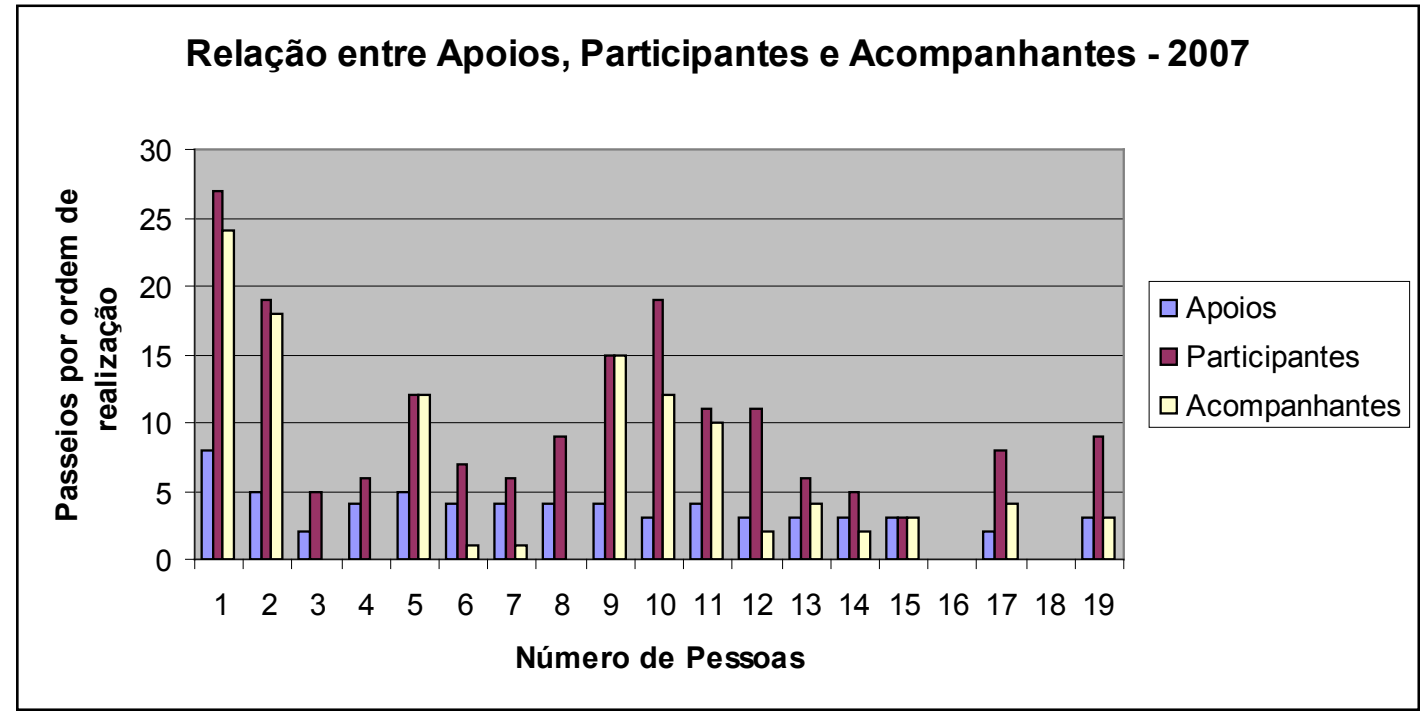


Gráfico 5 - Relação entre Apoios, Participantes e Acompanhantes nos passeios realizados em 2008

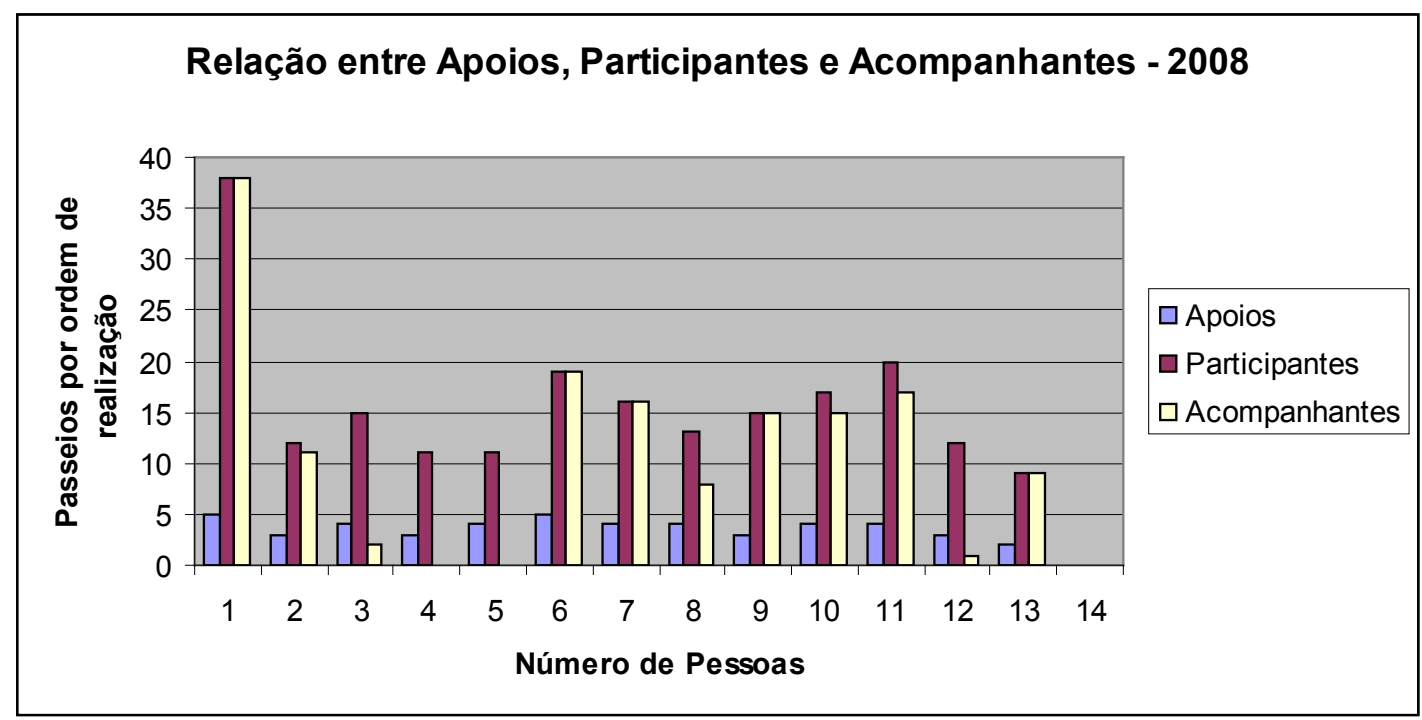

O Grupo de Apoio é também responsável pelo registro dos participantes presentes (lista de participantes por passeio) e fotografias. As listas de participação referentes a cada saída são confeccionadas a partir dos convites realizados aos participantes (elabora-se uma lista das pessoas que confirmaram a participação no passeio) e esta é complementada com a assinatura do termo de autorização para uso de imagens para divulgação do Projeto (Anexo D).

A função do Apoio pode ser definida pelo auxílio físico que proporcionam:

"Eles dão suporte. Que nem, tem gente que não consegue ir no banheiro. Eu nunca acompanhei ninguém, mas eu já vi várias pessoas, digamos normais, ajudarem pessoas ir no banheiro. Tipo, quando a gente vai entrar na van, eu, graças a Deus, consigo dobrar a minha perna e entrar. Outros não. Então, aí, o pessoal de Apoio pega no colo e coloca sentado, entende? Eu acho que sem esse pessoal seria muito dificil”. (Entrevista no8) 
Ou mesmo extrapolar esse papel, criando novas possibilidades:

"O importante é fazê-las trocar experiência, é o momento que elas tem de... Por tá num ambiente onde todos são iguais, de colocar pra fora as dúvidas que ela tem, sabe? Principalmente trocar essa experiência... "Ah, mas como você faz isso? Como você conseguiu colocar na escola? O meu estuda numa escola especial, eu morro de medo de tirá-lo de lá”... E um monte de problemas que elas têm, é o momento delas colocarem pra fora. Como que isso acontece? Com o Apoio fazendo a ponte. O Apoio tem que tá ali, percebendo isso, conversando com a pessoa, fazendo ela se abrir... Algumas vão no primeiro, no segundo passeio e não abrem a boca. Então, você não pode forçar, logicamente, mas elas escutam e observam. Então se eu sei que ali tem algum... Alguma dúvida, alguma coisa assim, eu puxo o assunto com a outra, pra que essa mãe que está quietinha escute. Porque o que a gente quer, a gente quer mostrar pra essas mães que elas têm vários caminhos, que esse pessoal, essa criançada tem direitos. Os mesmos direitos que uma criança sem deficiência tem, elas não enxergam muito isso." (Entrevista no 2 ) 


\subsubsection{Os Passeios}

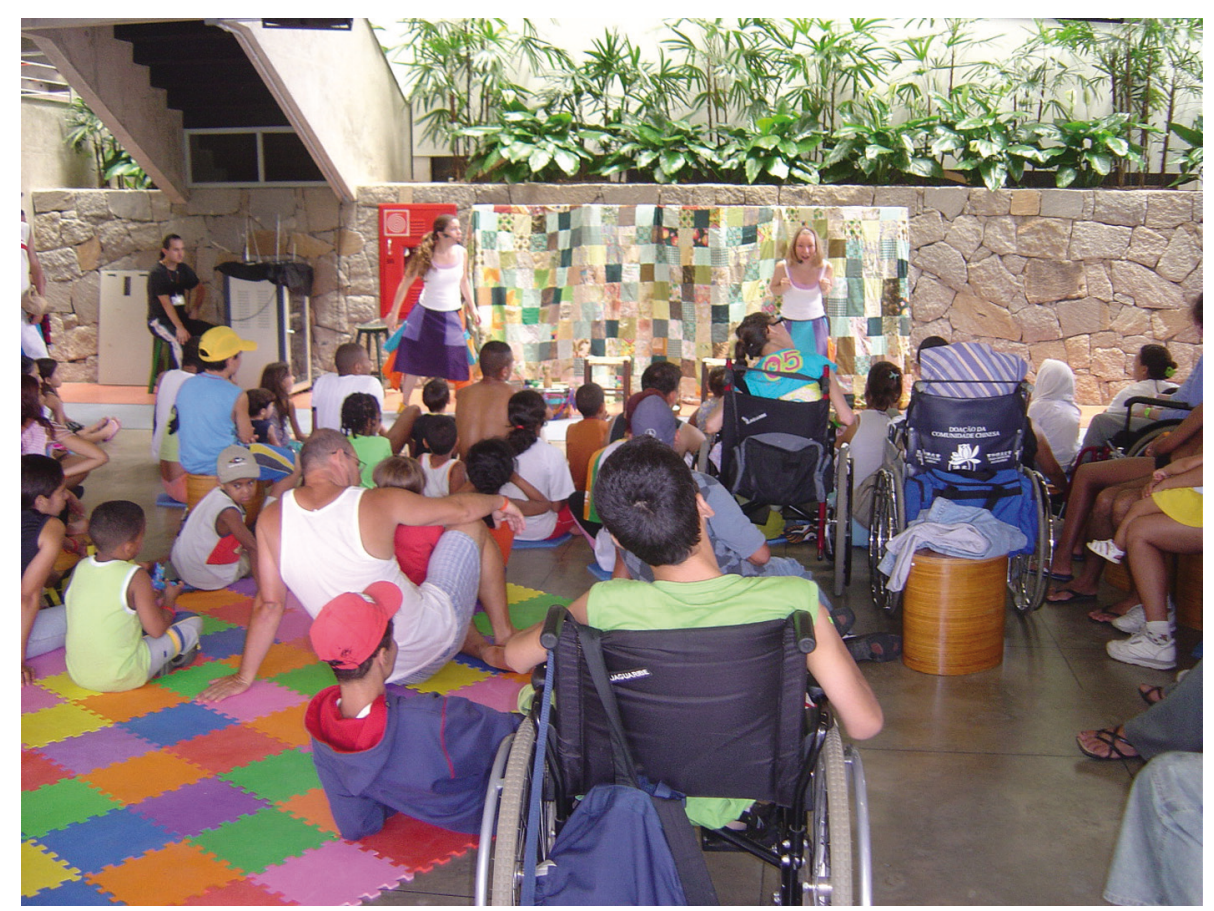

Foto 19 - Imagem do passeio realizado para o SESC Interlagos em 2006.

-Para viabilizar o Projeto, a GPPPD realiza a busca de parceiros, através da pesquisa de locais, espetáculos ou eventos, e o contato destes. Solicita-se a disponibilização de ingressos e realiza-se o convite aos participantes, de acordo com o número disponibilizado. A escolha dos convidados para cada passeio prioriza aqueles que nunca realizaram atividade com o Projeto. Entretanto, uma estratégia apontada e utilizada pelo Projeto é mesclar participantes que já passearam com o Andanças com outros que nunca tiveram esta experiência:

“E o que eu faço, o que eu sempre tento fazer nesses passeios... Se eu convido um cadeirante que nunca foi, eu então tento chamar um cadeirante que está acostumado a ir, pra que eles troquem, sem que um saiba disso, um saiba da situação do outro. Eu não comento nada da situação do outro, não importa. (...) um cara que está com muleta, 
eu chamo outro com muleta. Eu sempre tento colocar junto essas pessoas porque esse é o foco do Andanças. (...) Eu tô levando pra trocar experiência”. (Entrevista no 2)

Após convidar os participantes, a GPPPD organiza o transporte para o passeio, com o agendamento junto à Secretaria de Educação e Cultura. ${ }^{44}$ Por este motivo, o veículo era disponibilizado apenas nos finais de semana e período de férias, para não prejudicar a utilização do transporte na área da educação. Há, também, quando necessário, o agendamento do SETA (Serviço de Transporte Acessível), serviço oferecido pela própria GPPPD, para os participantes cadastrados neste serviço e que não possuem outros meios de se deslocar a partir de suas casas.

A proposta inicial previa o oferecimento de oito passeios por mês, sempre aos finais de semana, sendo quatro voltados para o público infanto-juvenil e quatro para adultos (GPPPD, 2007), totalizando 96 passeios em um ano. Acreditava-se, assim, poder contemplar todos os participantes do Projeto com, ao menos, uma saída por mês. No período compreendido entre 2006 e 2008, foram realizados 51 passeios, conforme os dados apresentados, a seguir, números bastante inferiores em relação à meta pretendida (Tabelas 6, 7, 8).

${ }^{44}$ Este funcionamento deu-se até o ano de 2008, quando a GPPPD fazia parte da Secretaria de Educação e Cultura. Com o remanejamento das instâncias administrativas, passando a GPPPD constituir parte da Secretaria de Obras e Planejamento Urbano, o acesso ao agendamento ao transporte foi dificultado por questões burocráticas. 
Tabela 6 - Descrição dos passeios realizados em 2006 pelo Projeto Andanças

\begin{tabular}{|c|c|c|c|}
\hline & Passeio & Gestor/ Contato & $\begin{array}{l}\text { Número de } \\
\text { Participantes* }\end{array}$ \\
\hline 1 & Praia & $\begin{array}{l}\text { Prefeitura Municipal de Praia } \\
\text { Grande }\end{array}$ & 66 \\
\hline 2 & Piquenique e Peça teatral & SESC Interlagos & 40 \\
\hline 3 & Peça: "As mulheres da minha vida" & Teatro Cultura Artística & 13 \\
\hline 4 & Tour Ribeirão & Prefeitura de Ribeirão Pires & 24 \\
\hline 5 & Circo & Circo Zanni & 10 \\
\hline 6 & Exposição - "Volpi: a música da dor" & Ibirapuera/MAM & 40 \\
\hline 7 & Circo & Circo Zanni & 11 \\
\hline 8 & Peça: "A Saga da Bruxa Morgana" & Teatro Alpha & 34 \\
\hline 9 & Show: "Banda Gigante" & SESC Santana & 30 \\
\hline 10 & $\begin{array}{l}\text { Peça: "Big Bang" Cia. Truks Teatro } \\
\text { de Bonecos }\end{array}$ & SESI Vila Leopoldina & 15 \\
\hline 11 & $\begin{array}{l}\text { Peça: "Big Bang" Cia. Truks Teatro } \\
\text { de Bonecos }\end{array}$ & SESI Vila Leopoldina & 18 \\
\hline 12 & Exposição: "Ilusão de Verdade" & SESC Pompéia & 30 \\
\hline 13 & $\begin{array}{l}\text { II Passeio do Jeep Club para Pessoas } \\
\text { com Deficiência }\end{array}$ & $\begin{array}{l}\text { Jeep Club de Ribeirão Pires/ } \\
\text { GPPPD }\end{array}$ & 27 \\
\hline 14 & Peça: "Rita Formiga" & $\begin{array}{l}\text { Teatro do Centro Cultural } \\
\text { Banco do Brasil }\end{array}$ & 06 \\
\hline 15 & City Tour em Santos & Prefeitura Municipal de Santos & 34 \\
\hline 16 & Show: "Maria Rita" & SESC Itaquera & 13 \\
\hline 17 & Show: "Ed Motta" & SESC Pompéia & 10 \\
\hline 18 & $\begin{array}{l}\text { Casa do Papai Noel - Banco Real/ } \\
\text { Parque da Água Branca }\end{array}$ & --- & 16 \\
\hline
\end{tabular}

Nota: Refere-se aqui ao número de pessoas com deficiência somados ao número de acompanhantes. 
Tabela 7 - Descrição dos passeios realizados em 2007 pelo Projeto Andanças

\begin{tabular}{l|l|l|l}
\hline & Passeio & Gestor/ Contato & $\begin{array}{l}\text { Números de } \\
\text { Participantes* }\end{array}$ \\
\hline 1 & Praia & Prefeitura Municipal de Praia Grande & 51 \\
\hline 2 & Peça: "Release" & Teatro Alpha & 37 \\
\hline 3 & Show: "Pato Fu" & SESC Vila Mariana & 05 \\
\hline 4 & Show: "Zé Geraldo" & SESC Santo André & 06 \\
\hline 5 & $\begin{array}{l}\text { Peça: "Miniteatro Ecológico } \\
\text { Giramundo" }\end{array}$ & SESC Avenida Paulista & 24 \\
\hline 7 & Show: "Jair Rodrigues" & SESC Santo André & 08 \\
\hline 8 & Show: "Zrnaldo Antunes" & SESC Santo André & 07 \\
\hline 9 & Peça & SESC Pinheiros & 13 \\
\hline 10 & Circo Zanni & SESI Vila Leopoldina & 30 \\
\hline 11 & Peça: "O Cravo e a Rosa" & SESC Pinheiros & 31 \\
\hline 12 & Peça: "A Graça da Vida" & Teatro Folha & 24 \\
\hline 13 & Peça: "A Graça da Vida" & Teatro Vivo & 12 \\
\hline 14 & Peça: "A Graça da Vida" & Teatro Vivo & 10 \\
\hline 15 & Peça: "Peter Pan e Wendy" & Teatro Alpha & 07 \\
\hline 16 & $\begin{array}{l}\text { III Passeio do Jeep Club para } \\
\text { Pessoas com Deficiência }\end{array}$ & Jeep Club de Ribeirão Pires/ & 06 \\
\hline 17 & $\begin{array}{l}\text { Grquestra Filarmônica de São } \\
\text { Bernardo do Campo }\end{array}$ & Teatro Cenforpe & 58 \\
\hline 18 & Circo & Circo Spacial & 09 \\
\hline 19 & Show: "Chico César" & Centro Cultural São Paulo & 10 \\
\hline & & & 12 \\
\hline
\end{tabular}

Nota: Refere-se aqui ao número de pessoas com deficiência somados ao número de acompanhantes.

Tabela 8 - Descrição dos passeios realizados em 2008 pelo Projeto Andanças

\begin{tabular}{l|l|l|l}
\hline & Passeio & Gestor/Contato & $\begin{array}{l}\text { Número de } \\
\text { Participantes* }\end{array}$ \\
\hline 1 & Praia & Prefeitura Municipal de Santos & 76 \\
\hline 2 & Passeio Ciclístico Inclusivo & $\begin{array}{l}\text { Secretaria de Esporte e Lazer da } \\
\text { Prefeitura Municipal de Ribeirão Pires }\end{array}$ & 21 \\
\hline 3 & Show: "Zeca Baleiro" & SESC Santo André & 17 \\
\hline 4 & Peça: "H.E.R.O.I.S" & Centro Cultural São Paulo & 11 \\
\hline 5 & Peça: "Histórias da Caixola" & Centro Cultural São Paulo & 38 \\
\hline 6 & Show: "Zélia Duncan" & SESC Interlagos & 11 \\
\hline 7 & Peça: "A História do Barquinho" & Centro Cultural São Paulo & 32 \\
\hline 8 & Ciclotur Inclusivo & Parque das Bicicletas & 21 \\
\hline 9 & Peça: "Cadê Kika?" & Centro Cultural São Paulo & 30 \\
\hline 10 & Visita à Base do Exército & Base do Exército de Taubaté & 32 \\
\hline 11 & Visita à Base do Exército & Base do Exército de Taubaté & 37 \\
\hline 12 & Show: "Ivan Lins" & SESC Santo André & 13 \\
\hline 13 & Peça: "O Cadarço Laranja" & SESC Consolação & 18 \\
\hline 14 & $\begin{array}{l}\text { IV Passeio do Jeep Club para } \\
\text { Pessoas com Deficiência }\end{array}$ & Jeep Club de Ribeirão Pires/ GPPPD & 70 \\
\hline
\end{tabular}

Nota: Refere-se aqui ao número de pessoas com deficiência somados ao número de acompanhantes. 


\subsubsection{Possibilidades E Participações}

O Projeto afirma as possibilidades e a acessibilidade, também, quanto aos custos de realização. Segundo a PMETRP $(2007),{ }^{45}$ o custo mensal por pessoa deste Projeto é de $\mathrm{R} \$ 3,81 .^{46}$ Se se tomarem as possibilidades de ampliação da circulação social e cultural e da instauração de novas experiências para a população com deficiência, pode-se considerar que se trata de um investimento pequeno em relação às possibilidades de vida e de empoderamento dessa população e suas famílias.

Em relação à participação de cada um dos cadastrados, observa-se a dificuldade da equipe da GPPPD em manter o rodízio das pessoas. No levantamento efetuado sobre o número de passeios realizados por cada participante, revelamse dados discrepantes: das 249 pessoas cadastradas no Projeto, apenas 13 realizaram 10 ou mais passeios (Tabela 2, cap. 3). Aponta-se como causadores desta questão, o pequeno número de funcionários responsáveis pelo Projeto em relação ao número de participantes cadastrados. Em 2007, a GPPPD contava com três funcionárias para a gestão de todos os projetos (EHM; ALJ; LM), chegando a ter no máximo cinco funcionários em 2008 (EHM; TCAM; ALT; T; R). As ações do Projeto Andanças contavam também com a voluntária PACS, que é integrante do Movimento de Apoio à Pessoa com Deficiência do Município. Entretanto, parece-nos haver uma sobrecarga em relação ao trabalho proposto pela GPPPD, pois além do trabalho do Andanças que acontece aos finais de semana, os mesmos funcioná-

\footnotetext{
${ }^{45}$ Cálculo realizado em 2006, considerando duas saídas em um mês, sendo uma para 44 pessoas e outra para 16 pessoas, entre participantes e acompanhantes. As saídas para 44 pessoas são previstas para crianças e adolescentes que necessitam de acompanhante e as saídas para 16 pessoas são previstas para jovens e adultos que não necessitam de acompanhantes. Também são levados em conta que o número de ingressos disponibilizados depende do local do passeio. São incluídos no calculo os custos com combustível e pagamento de hora extra para a Equipe de Apoio (que pode optar por receber as horas trabalhadas como descanso - banco de horas) (PMETRP, 2007).

${ }^{46}$ É preciso considerar que o valor da hora extra pago a cada funcionário que participa do Andanças, é calculado a partir do salário base de cada categoria profissional e do piso salarial estabelecido no município de Ribeirão Pires.
} 
rios são responsáveis pela gestão de outras ações da GPPPD durante a semana, ultrapassando uma carga horária de mais de 40 horas semanais. Apesar da proposta de rodízio dos profissionais, observa-se nas Tabelas 3, 4 e 5 (4.2.2 A Equipe de Apoio) que a Equipe de Apoio foi sendo reduzida não só quanto ao número de profissionais por passeio, mas também quanto ao número total de pessoas que compuseram o Grupo de Apoio ao longo do ano.

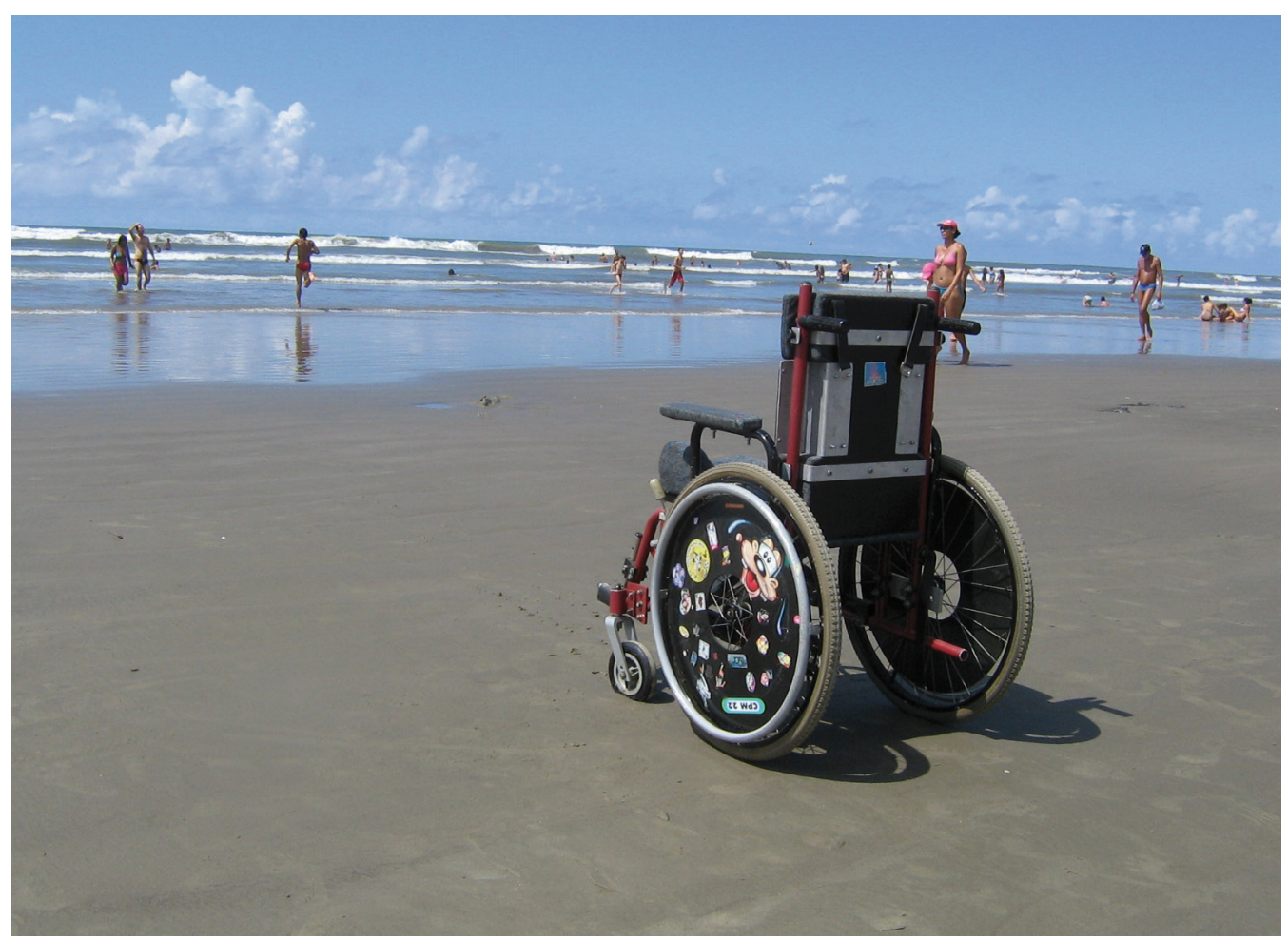

Foto 20 - Cadeira de participante do Projeto Andanças durante o passeio à Praia Grande, em 2006.

Participantes, Equipe de Apoio, Passeios, Possibilidades e Participações constituíram unidades descritivas que favoreceram a apresentação do Projeto Andanças. Elementos que operam de maneira estritamente articulada, cuja caracterização revela traços que apontam para os temas-categorias estabelecidos para a análise: PARTICIPAÇÃo SOCIAL; ENVOLVIMENTO AFETIVO E SUbJETIVO; ALTERIDADE; CONHECIMENTO TÁCITO; E O LAZER. 
5 ANÁLISE E

\section{DisCUSSÃO: OS DADOS}

DA EXPERIÊNCIA

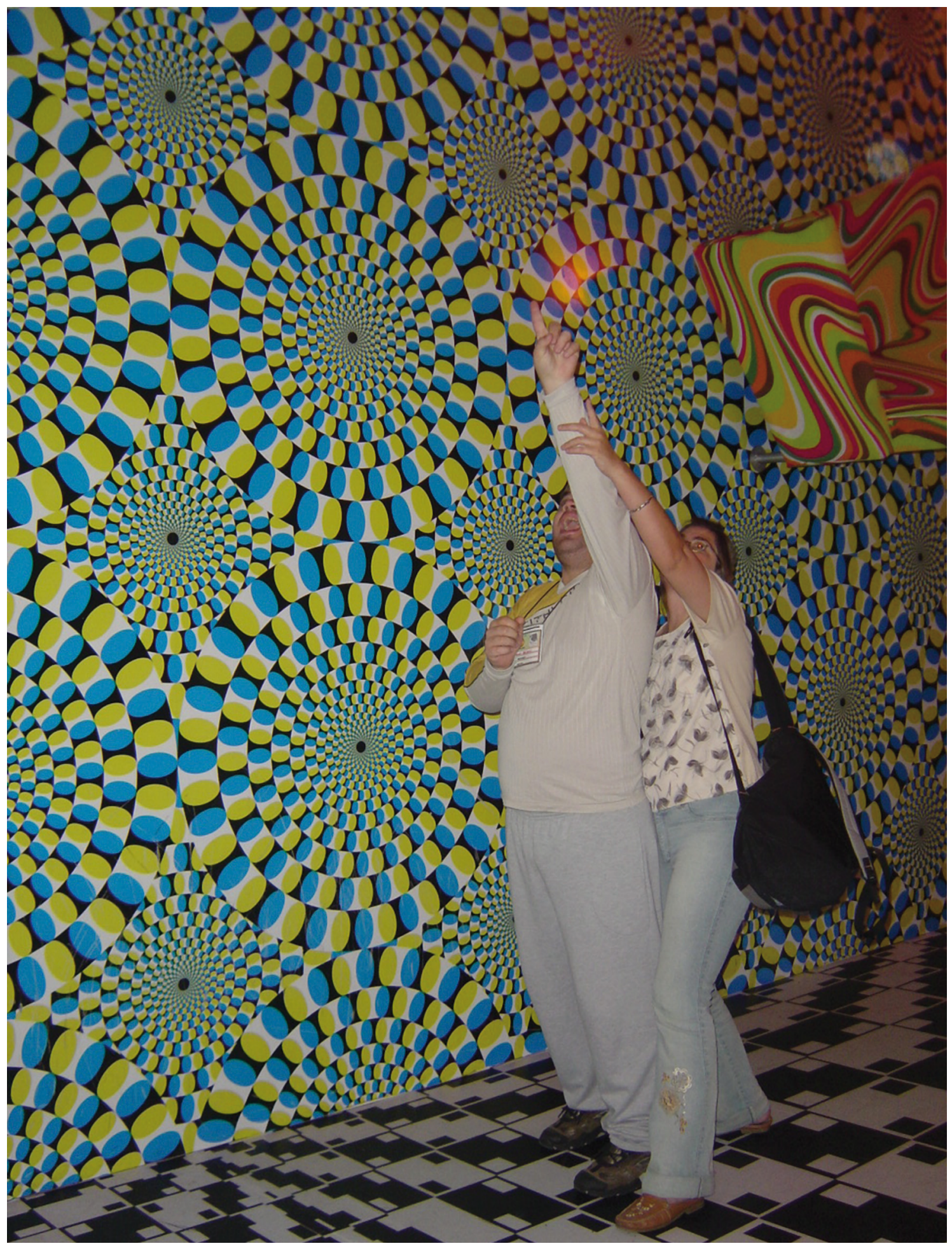

Foto 21 - Exposição Ilusão de Verdade. Participantes do Projeto Andanças em visita ao SESC Pompéia, em 2006. 
A análise e a discussão, ora apresentadas, foram construídas a partir de trechos das Entrevistas realizadas; dos Discursos do Sujeito Coletivo (DSCs), provenientes destas; e do Diário de Campo elaborado durante a pesquisa.

A nomenclatura apresentada para identificar os DSCs, de acordo com os grupos, a partir dos quais foram construídos, foi utilizada da seguinte forma: DSC Grupo I ou DSC Grupo II, para referir-se a discursos produzidos, respectivamente, por pessoas que integraram a criação e gestão do Projeto, e participantes com deficiência ou seus acompanhantes. As Idéias Centrais (IC) identificadas nos DSCs, juntamente com os temas empíricos de análise, que emergiram na leitura do Diário de Campo, possibilitaram a construção de categorias temáticas para análise e discussão. São elas: PARTICIPAÇÃo SOCIAL; ENVOLVIMENTO AFETIVO E SUbJETIVO; ALTERIDADE; CONHECIMENTO TÁCITO; E O LAZER.

\subsection{ParticipaÇÃo Social}

“É porque você tem que se expor um pouco pra você poder participar". (Entrevista nำ7)

O tema da Participação Social atravessa os DSCs de maneira recorrente e de forma diferenciada: apontam uma situação de restrição; falam das dificuldades ocasionadas por barreiras físicas ou atitudinais; e apontam como resultado do Projeto um aumento na participação. Dois pontos importantes a se destacar são a necessidade de se colocar em situações de participação, e a de facilitar para que essas circunstâncias aconteçam. 


\section{IC (Idéia Central): A restrita participação social das pessoas com deficiência e suas famílias}

Apesar do que foi apresentado nos capítulos teóricos em relação às mudanças históricas do olhar para as pessoas com deficiência, a participação social dessas populações foi descrita, a princípio, como restrita a alguns contextos como a própria moradia, a escola ou serviços de saúde:

\section{DSG (Discurso do Sujeito Coletivo) - Grupo I}

Os motoristas do transporte adaptado observaram que as crianças e adolescentes, que usam o serviço, só iam no roteiro casa-escola. E eles perguntavam: "Ué, nunca foi pra tal lugar?". E a mãe: “Eu também nunca fui, nunca tive tempo!”. Ou leva ao médico ou fica internado, essa é a saída deles. Então, quando fizemos a primeira trilha de jipe a gente viu o tamanho, o volume de pessoas que não saíam de casa.

Hoje, tem algumas pessoas que só saem com a gente, com o Andanças. São casos extremos: por exemplo, uma pessoa com deficiência, adulta, pesada, de pais idosos. Ou um jovem cadeirante, que a avó é cega e a mãe, sem recursos, tem quer dar conta sozinha de ambos.

No Discurso produzido pelo Grupo I, apresentam-se dois momentos: um contexto anterior à criação do Projeto Andanças e outro posterior. No primeiro, observa-se a constatação desta situação de restrição e, no segundo, fica implícita que houve uma mudança com o início do Projeto, indicando que as ações voltadas para favorecer a participação social das pessoas com deficiência 
são essenciais para que a condição inicial possa ser alterada. O Discurso produzido pelo Grupo II não identifica uma mudança na participação a partir da experiência com o Projeto Andanças, apontando para as dificuldades cotidianas na circulação social dessas pessoas.

As barreiras arquitetônicas são apontadas como grandes elementos de restrição para a participação social, no caso das pessoas com deficiência física.

\section{DSC Grupo I}

Algumas pessoas além de ter a deficiência moram em um lugar muito difícil, moram em um local onde mal entra ônibus. Se chover, o ônibus não entra. Muitos que a gente atendeu no Andanças, ou a casa era muito para baixo ou muito para cima: mais de quarenta degraus para subir ou para descer. Pô, cadeirante com escada não combina!

E tem muito disso, parece que é só para judiar. Tem muitos que não têm condições de ir para outro lugar, então só o Andanças mesmo. A gente sabe que se a gente não for buscar aquela pessoa para sair, ela não vai sair de casa...

\section{DSC Grupo II}

Ele não convive. A gente não sai porque mora em lugar difícil. Tem criança ali que nunca saiu de casa, por estar numa cadeira de roda, por ser adulto e ter que carregar. A gente não tem nem condução própria. Quando você tem um carro, um transporte próprio você pode até colocá-los numa pracinha, mesmo com dificuldade você ainda se vira. 


\section{DSC Grupo II}

A minha maior dificuldade é sair de casa. Eu não tenho condução própria, é muito difícil: tem que pegar, descer de cadeira de rodas. Tem degrau, tem rampa, não é asfaltado. O ônibus daqui não é adaptado. Eu tenho que descer o morro com cadeira de rodas, subir no ônibus com a cadeira de rodas, tudo. Então pra mim é mais difícil. Se tiver chovendo eu não tenho condições nem de chegar no portão. Porque aqui não é asfaltado. Tudo dificulta a minha vida e a vida do meu filho pra poder sair de casa.

Os Discursos de ambos os grupos enfatizam as dificuldades encontradas para sair de casa. Esta questão remete às condições de moradia e renda dessa população que, além de encontrar dificuldades para adaptar suas casas de acordo com as suas necessidades, de forma a favorecer a circulação e acessar meios de transporte, moram em regiões precárias da cidade, onde há menos recursos disponibilizados, como é o caso do ônibus adaptado. A chuva, barreira para mobilidade de todos, dependendo de sua intensidade, quando não é um impedimento por si só, tem um grande risco de acentuar ainda mais as dificuldades para as pessoas com deficiência, quando os ambientes não são acessíveis.

Apesar de a legislação assinalar que é de responsabilidade dos governos municipais desenvolver estratégias que eliminem as barreiras físicas, estas ações parecem não atingir a todos os munícipes (Neri, 2003).

O Projeto Andanças, em sua prática territorial de sensibilização, chama a atenção das pessoas para a questão da acessibilidade. Diante da existência de barreiras arquitetônicas, urbanísticas ou de transporte, ${ }^{47}$ vivem-se situações

\footnotetext{
$\overline{47}$ Neri (2003) explica que as barreiras físicas podem ser arquitetônicas: "obstáculos aos acessos existentes em edificações de uso público ou privado, bem como à sua utilização interna”; urbanísticas: "dificuldades encontradas pelas pessoas nos espaços e mobiliários urbanos; e de transporte: "dificuldades ou impedimentos apresentados pela falta de adaptação dos veículos particulares ou coletivos às necessidades das pessoas com deficiência".
} 
que demandam a criação de estratégias específicas para a viabilização de um passeio. O trecho, a seguir, do Diário de Campo (2008), a chegada da van no SESC Interlagos, onde a equipe do local demora a compreender a complexidade de acessibilidade do Grupo:

[...] "a orientação é de que a van siga até um dos funcionários que indicaria onde estacionar. O "rapaz de azul" aponta:"Vocês param aqui!". Tentamos compreender como chegaríamos à platéia. O funcionário orienta que depois o grupo desça as escadas. Ele corre para atender outro carro. É necessário ir atrás dele para verificar outra possibilidade de acesso. "Moço, não é possível seguir pelas escadas! Tem três pessoas de cadeira de rodas, quatro cegos e outras pessoas com muletas... Não tem outro acesso, mais próximo?". Ele pede que esperemos e aciona o rádio perguntando se podia nos liberar... Com a resposta positiva, indica o caminho que devemos seguir. A van teve a possibilidade de estacionar ao lado do palco. O grupo desceu do transporte, os rapazes do Apoio armaram as cadeiras de rodas. Várias pessoas do local se aproximavam numa tentativa de ajudar, mas sem saber ao certo o que fazer". (Passeio 005/2008, em 30/03/2009, show da Zélia Duncan)

A instituição, mesmo avisada previamente da chegada do grupo de pessoas com deficiência, pareceu ser tomada por um inesperado: como agir? Como ajudar? Situação que redimensiona a questão da deficiência junto a esses trabalhadores. Foi necessária a criação de uma pequena solução, a partir das necessidades que emergiram naquela circunstância (Rocha et al., 2003). 
As dificuldades de acessibilidade física são uma dimensão das barreiras enfrentadas pelas pessoas com deficiência, para a sua participação social. Outro aspecto fundamental diz respeito às atitudes das pessoas em face da questão da deficiência.

\section{IC: As barreiras de atitude: imaginários que restringem}

\section{DSC Grupo I}

A maior recusa que a gente teve foi na primeira tentativa de saída do Andanças. A gente ia pra praia. Mas a cidade colocou uma série de impedimentos, deram algumas desculpas: as crianças não podiam comer na areia, só podiam comer dentro do ônibus; tinha uma série de não podias. Os "não podias" se traduziam em: "Vocês não venham”. Então, nós não fomos realmente.

As barreiras de atitude, camufladas, ainda estão presentes no cotidiano dessas pessoas. Os avanços teóricos e conceituais inibem situações explícitas de atitudes negativas quanto à presença dessas populações nos espaços sociais. Dessa forma, o discurso é maquiado e resurge constantemente no contato com as diferentes instâncias sociais, ou dentro de suas próprias casas:

\section{DSC Grupo I}

Foi difícil colocar na cabeça do próprio deficiente que ele tinha de sair de dentro de casa. E da família. A família não é tão próxima. O apoio deles geralmente é a mãe. O receio vem de dentro de casa. O mais chato pra nós é isso. Como aconteceu 
de ter passeio e a pessoa querer ir, mas não ter um acompanhante. Porque ninguém queria ir passear. "Eu não vou passear com um deficiente, empurrar um deficiente na Avenida Paulista". "Eu? Eu vou morrer de vergonha, todo mundo olhando pra ele!". Teve mãe, que nunca foi pra praia com a gente, que fala assim: "Eu não vou expor meu filho na praia, no meio de todo mundo?”.

Um imaginário social negativo acerca da deficiência favorece experiências negativas das pessoas com deficiência, com as pessoas sem deficiência. As reações estigmatizantes têm um espaço de ação configurado a partir destes imaginários. Dessa forma, constituem-se barreiras de participação que implicam a atitude em face da questão, o que é acompanhada do pensamento sobre esta (Martinelli, 2008; Pereira, 2006).

Assim, a mudança do imaginário social faz-se fundamental, para que as experiências entre pessoas com e sem deficiência aconteçam de forma positiva. O pensamento e as ações podem ser modificados na própria vivência com a questão, no contato com as diferenças:

[...] "O contato favorece. Por isso que educação inclusiva é tão importante. Porque o contato favorece muito. Então, por exemplo, na trilha de jipe, quando a gente pega um empresário, quando a gente pega um gestor de alguma empresa, um gerente, ele fala: "Ah, entendi a lei de cotas!". Então ele para de contratar pela obrigação e para entender, passa a entender que essa pessoa é funcional. Então acho que é um pouco disso, o contato favorece isso tudo". (Entrevista $\mathrm{n}$ ำ ) 
O imaginário social negativo não impede o movimento de participação dessas populações e seus familiares. Elas se mostram mais impedidas em relação ao olhar dos outros para a deficiência: este parece um importante inibidor de atitudes que desfavorecem (quando não impedem) uma ampliação da circulação social dessas pessoas:

\section{DSC grupo II}

Quando eu saio com ele, os outros olham, discriminam. Mas a gente não quer aceitar o olhar diferente das outras pessoas porque dói. Aquele olhar assim tipo de receio, às vezes aquele olhar de dó. Às vezes, eu penso, a pessoa não vai aceitar. Querer, aceitar, porque tem criança que faz barulho, tem criança que...

Dessa forma, sair juntos parece constituir uma importante estratégia de desmonte das barreiras atitudinais, em relação às próprias famílias e às pessoas com deficiência. À medida que enfrentam juntos o olhar da sociedade, mostram-se fortalecidos para sustentar as diferenças no espaço social.

"Muitos deficientes tem vergonha de por a cara. Só que estando num grupo é diferente. Eles se tornam mais forte, fortalece a pessoa. Você vê, são pessoas passando por cima de tantos obstáculos. Um fortalecia o outro. São pessoas tão graves, mas um fortalece o outro". (Entrevista $\mathrm{n}-8$ ) 


\section{IC: A participação foi ampliada após a experiência com o Andanças}

Diante das dificuldades de participação, apresentadas anteriormente, e a instauração de uma política pública, que tem como objetivo possibilitar o acesso a atividades de lazer, cria-se a expectativa de ampliação da circulação social dessas pessoas. Esta é, entretanto, observada como decorrente das ações do Projeto Andanças, somente no Discurso do Grupo I, sendo as experiências dos passeios apresentadas como propulsoras da participação:

\section{DSC Grupo I}

É só pra abrir porta mesmo. Foi pra iniciar, para dar o chute inicial e abrir a porta pra essa galera também, os participantes saberem que eles podem sair de casa e reivindicar. Hoje têm muitos lugares que se adaptaram rapidamente pra atender essa demanda. Dizem aí que já tem até point deles, que eles se encontram num barzinho... E o bar se adaptou pra receber eles.

Antes, você batia na porta de muitos: "Tem algum deficiente, você tem alguma deficiência?". "Não!”. Só que ele estava lá, escondido. Hoje não. Hoje você vê que eles saem na rua. Tem dia que você vai na praça e vê muito mais pessoas com deficiência do que gente sem. Eu acho que isso mudou muito a vida de todo mundo. Tanto dos que são, como daqueles que não são. As famílias de crianças com deficiência aprenderam a se sentir orgulhosas de seus filhos, então, elas saem mais. A gente vê as pessoas com deficiência, os adultos, os jovens e adultos, circulando mais pela cidade.

Hoje, aqui na cidade, eu vejo que as pessoas respeitam mais. Você tem sinal para um cego atravessar a rua, não tinha. Elas conseguem parar para um outro atravessar, se ele tem alguma deficiência. Eles não estacionam mais na vaga, porque viu que aquilo era errado. 
Em relação ao Grupo II, apenas em uma das entrevistas é possível identificar a ampliação dos atos cotidianos do participante. Por isso, não foi possível, para esta Ideia, a construção de um DSC representativo do grupo.

"Antes de eu participar disso, eu era 'a deficiente', 'a coitada', aquela que precisava de ajuda. Em tudo. Se não tinha lugar pra estacionar eu ia embora, entende? Não dava e pronto. De repente com o Andanças, que você vê mais deficiente junto, eu me senti superútil, porque eu podia ajudar as outras pessoas, tipo, vai um deficiente visual. Eu não tenho equilíbrio, mas ele tem. Ele não tem a visão, mas eu tenho. Uma deficiência acaba complementado a outra. Então, de repente, tinha cadeirantes. Cadeirante não anda, mas eu ando e a cadeira me dá o equilíbrio, porque eu não tenho. Hoje, eu me sinto útil, pronta pra te ajudar. De repente você tropeça aqui e eu estou do lado pra dar o apoio, pra te ajudar a levantar, não é? De repente vai, você está com sede, poxa... Eu posso... Não posso carregar um copo de água. Devido ao meu desequilíbrio, vai cair tudo. Trago meio copo. Hoje eu me sinto útil. Antigamente eu ia esperar você pegar água pra mim. Hoje, não. Eu faço questão de te servir um cafezinho. Entende? É diferente. Pra mim essa foi a grande serventia”. (Entrevista no8)

No trecho apresentado, a ampliação da participação social não é acentuada como resultado decorrente da experiência com o Projeto Andanças. Entretanto, identifica-se a ideia em questão no universo micropolítico, com um maior envolvimento em situações da vida, com uma ampliação dos atos cotidianos (Lima, 1983; Rolnik, 1993). 
No DSC do Grupo I são apresentadas as mudanças observadas nas cenas do cotidiano de Ribeirão Pires. São relatos que retratam imagens da cidade, como fotografias panorâmicas que apresentam novos detalhes, captam o universo macropolítico.

Apesar de não relatarem (talvez mesmo, não perceberem) o aumento na própria circulação social ou na de seus filhos com deficiência, o Grupo II revela que a experiência dos passeios com o Projeto Andanças abre para novos modos de pensar, desconstruindo imaginários sociais estabelecidos e favorecendo a presença dessas populações nos diferentes espaços sociais:

\section{DSC grupo II}

O Andanças foi esse primeiro passo para o desafio da vida das pessoas com deficiência. O Andanças mostra o outro lado, mostra que a vida não acabou, que o mundo não é só a casa da pessoa, não é só os familiares. O mundo é pra todo mundo, mesmo sendo um cadeirante, mesmo sendo uma pessoa com deficiência visual ou com deficiência mental. O mundo é pra todo mundo, independente de ter uma deficiência ou não, é pra todos. O Andanças faz a gente, pai, mãe, tio e tia, ver a diferença na vida da pessoa com deficiência, que é a inclusão. Com esse negócio Andanças, hoje eu vejo mais, principalmente deficiente visual, na rua. E eu percebo que, com isso, o deficiente ganha força. Eu percebo que, em outra cidade, as pessoas olham mais. Ficam mais assim, parecendo que assustadas. Em Ribeirão eu acho que as pessoas já estão até mais acostumadas.

Colocar o pensamento em movimento não amplia a participação social em si, mas cria condições favoráveis para que as pessoas com deficiência 
se envolvam com diferentes situações na vida. Um novo leque de mudanças sutis passa a operar e o território da cidade ganha uma nova materialidade pelo acolhimento e pela ação efetivados. É na experiência que esse processo é estabelecido: vivenciar as diferenças e criar as pequenas soluções permitem a construção de um conhecimento sobre aquilo que inicialmente é estranho. Este saber torna-se, então, partilhado e é expresso nos diversos encontros entre pessoas com e sem deficiência: um conhecimento sobre a questão da deficiência se configura e já não assusta mais as pessoas, que ficam acostumadas com as novas configurações da diferença constituindo os cenários cotidianos. Um deslocamento é realizado: pensar a participação social dessas populações, como algo natural no cotidiano das pessoas, é uma ideia que foi construída a partir do que foi vivido na experiência do Projeto Andanças (Law, 2010; Rocha et al., 2003).

\section{IC: Colocar-se em situação de participação}

Envolver-se em situações da vida cotidiana implica não apenas oportunidades para tal, como também um movimento do sujeito de se colocar na situação. Expor-se. O que implica chamar a atenção do olhar do outro para si. Esta ideia remete à questão dos imaginários em relação ao olhar do outro, que passam, dessa forma, a constituir barreiras de atitude, conforme abordado na Ideia Central: As barreiras de atitude: imaginários que restringem.

Apesar das barreiras físicas e atitudinais, o colocar-se em situação de participação foi uma ideia importante, que possibilitou a construção do Discurso do Grupo I. 


\section{DSC Grupo I}

Se você não procurar o seu lugar na sociedade, a sociedade vai te excluir mesmo. A questão é sair de casa. Então, você tem que se impor. Nos passeios, a grande maioria não se preocupava muito para onde ia: "É para passear, estamos dentro!". Não quer nem saber se vai chover ou fazer Sol, só o fato de passear... E a gente incentivava: "Vai estudar, meu, vai fazer alguma coisa! Vem pra praça...". O cara: “Ah, mas tem escada...”. Paciência! "Não tem uma rampa”. "Paciência! Peça ajuda! Faça o outro entender que você precisa disso. A gente tem que mostrar a cara, a gente tem que sair”. E a gente ajudou eles a se imporem.

O movimento das pessoas com deficiência, de colocar-se em situação, parece corresponder à dimensão micropolítica e intervém em estruturas moleculares (Guattari e Rolnik, 1996) e sensíveis: as relações entre pessoas com e sem deficiência. Colocar-se em situação de participação favorece uma ampliação dos atos cotidianos e do envolvimento das pessoas com deficiência em outras situações da vida, ocasionando uma ampliação da participação social. Entretanto, em relação ao Grupo II, a Ideia Central aparece verbalizada somente em uma das entrevistas:

[...] "Pra mudar o olhar das pessoas a gente também tem que participar. Apesar de ser um pouco difícil. Às vezes, tem que mudar um pouco a cabeça dos familiares também, porque é muito doído para as pessoas, para os familiares se expor... É porque você tem que se expor um pouco pra você poder participar”. (Entrevista $\mathrm{n} \underline{\mathrm{o}} \mathbf{7})$ 
Os sentimentos dos familiares marcam a dificuldade dessas populações em participar, pois o movimento de colocar-se em situação de participação, também, depende, muitas vezes, da ação da própria família, quando esta necessita, em decorrência das limitações, acompanhar a pessoa com deficiência nos espaços sociais. É o imaginário da família em relação à questão da deficiência influenciando os movimentos do próprio sujeito com deficiência, e de sua família.

Mesmo não verbalizados, os gestos e as ações dessas pessoas indicam a importância e a ampliação do movimento de colocar-se em situações de participação (Diário de Campo, 2008):

[...] "L. olha pra o relógio e diz que faltam 30 minutos para acabar. Depois do lanche, L. parecia mais descontraído. Divertiu-se atrapalhando as fotos de T., colocando a mão na frente, quando ela ia bater uma foto. Disse que era legal. Ele continuava a olhar o relógio para ver quanto tempo restava para acabar o show. Aproveitei o "gancho" e brinquei dizendo que ele queria ir embora. Perguntei a ele se estava gostando. Não obtive resposta clara, pois L. respondia coisas diferentes a cada vez que eu perguntava: 'É muito barulho'; 'A luz me incomoda'; 'Eu preciso passear, sair de casa””. (Passeio 003/2008, em 09/02/2008, SESC Santo André, show do Zeca Baleiro)

“O R. é um menino que nunca tinha saído à noite sozinho. Tem paralisia cerebral, tal. Tem 25 anos. Tem 25, 26 anos. Quando a gente foi ao teatro e tocou, tocaram-se os sinais do teatro e aí o teatro ficou escuro, ele ficou desesperado. Ele não entendia 
o que ia acontecer. Então, aí ele queria ir ao banheiro e tinha de ser naquela hora, então, tem o F. estava ali pra mediar e dizer: 'Não, você não pode ir agora...', porque ele não sabia o que era. Falta esse contato. O R. é um menino que aprendeu inclusive a dizer assim: 'eu só ficava em casa. Hoje eu quero dar uma volta de ônibus pela cidade’. E ele dá uma volta de ônibus pela cidade. Quer dizer, pra ele, que só ficava em casa, às vezes, hoje, circular, dar uma volta de ônibus pela cidade não é importante. Mas aqueles vinte passageiros, quinze, trinta, quarenta que estão no ônibus que veem o R. entrar são impactados pela presença do R.”. (Entrevista $\mathrm{n}^{\mathrm{o}} 1$ ).

O vivido em cada passeio possibilita a criação de um repertório de experiências e o conhecimento dos rituais a elas relacionado: um aprendizado dos saberes compartilhados socialmente, como, por exemplo, tomar ciência de que as luzes são apagadas no teatro para o início do espetáculo. Exercício realizado no acompanhamento e com a mediação atenta da Equipe de Apoio, o que favorece a construção de um entendimento que implica o reconhecimento das próprias sensações pelos sujeitos: conhecer o mundo e a si mesmo.

"Ele vai tendo mais conhecimento. Porque é assim quanto mais a gente sai, mais a gente aprende. Quanto mais você vê coisas diferentes, é coisa que você fala: "Poxa é coisa que eu nunca vi, agora eu tive conhecimento". Entendeu?”. (Entrevista no9)

No DSC produzido pelo Grupo I, a questão é abordada não como movimento exclusivo das pessoas com deficiência, mas como uma via de mão dupla (Sassaki, 1997), necessitando, também, a criação de situações ou elemen- 
tos que favoreçam a participação, como o convite para um passeio. Outras estratégias constituíram-se na experiência.

\section{IC: É preciso favorecer a participação}

Ao ser constituído como um dispositivo que favorece a participação, o Projeto Andanças parte do princípio de que a participação é um direito, o que implica a necessidade de oferecer igualdade de oportunidades para as populações em desvantagem, como as com deficiência:

[...] "Eles são um grupo de pessoas que tem menos condição de ter acesso, e toda casa de espetáculo tem uma cota de ingresso pra ser distribuída. Então a gente só junta as duas coisas.

A gente não vai buscar em casa, muito difícil. Só se for alguém assim, que não tem condição nenhuma mesmo, caso contrário não. Agora, a gente sabe que a gente facilita sim. Mas facilita nesse sentido de que se você não criar algumas facilidades, hoje ainda, eles não vão sair nunca. Mas a gente tenta dar um sentido que ele não é caritativo”. (Entrevista $\mathrm{n} \mathbf{o} 1$ )

Diante de tal pressuposto, a facilitação da participação foi construída a partir de estratégias diferentes. Uma delas, fundamental neste processo, constitui-se com a Equipe de Apoio. 


\section{DSC grupo II}

Eu acho que é difícil a locomoção, principalmente. Pra eu andar com ele é complicado. Eu tenho que ajudar, tem que apoiar. Então é muita coisa, não dá. A Equipe de Apoio facilita bastante, justamente por causa da locomoção. Eles dão suporte. Que nem, tem gente que não consegue ir no banheiro. Quando a gente vai entrar, o pessoal de Apoio pega muitos no colo e coloca sentado, entende? Eu acho que sem esse pessoal seria muito difícil.

\section{DSC grupo I}

No começo, a gente ouvia: "Nossa, a gente não tem estrutura para isso!”. A gente falava assim: "Não precisa ter estrutura que os Apoios estão indo para isso, para essa estrutura que vocês dizem que não tem". A Equipe de Apoio o que é? É chegar lá, embarcar e desembarcar eles. Às vezes, quando é muito pesado pra mãe, faz o apoio de levar ao banheiro. Isso, a gente toma a frente. Mas é realmente quando precisa. Porque você tem que deixar a criança e o acompanhante dela a vontade. Mas, assim, observando de longe.

A atuação mais claramente definida nas atribuições da Equipe de Apoio diz respeito à facilitação dos acessos físicos. Favorecer a participação superando as barreiras físicas com simples estratégias: pegar no colo, carregar o deficiente, dobrar cadeira, carregar cadeira, montar cadeira, colocar o sujeito em seu dispositivo de mobilidade. Minúcias que exigem um exercício de desacelerar: parar, olhar, ser afetado, pensar (Sant'anna, 2001; Quarentei, 2006). Deslocar as ações de um fazer automatizado, ao qual se é submetido no dia a dia do sistema capitalista, objetivando uma otimização do tempo para a máxi- 
ma produção. Criação de fazeres a partir de cada situação, de acordo com a singularidade, diferença e necessidades que são colocadas naquele momento. Ações que, muitas vezes, invadem uma privacidade por vezes desconhecida: acompanhar aqueles que não conseguem ir ao banheiro sozinhos. Quando os gestos, a aproximação e o acompanhamento são realizados com delicadeza, constrói-se um conhecimento relacional (consigo e com o outro), de forma respeitosa e sutil. No banheiro, as barreiras colocadas não são apenas física, dizem também respeito a um conhecimento e um manejo de si. Solucionar estas dificuldades implicam que, para além da construção da acessibilidade física, os gestos sutis do acompanhante permitam ao acompanhado relacionarse melhor consigo.

Já na acomodação do transporte, as dificuldades são solucionadas de forma coletiva, como relatado no Diário de Campo (2008):

[...] P. solicitou que as pessoas subissem no transporte. A Equipe de Apoio, L. e J., colocaram também os cadeirantes, para então pensar onde seriam colocadas as cadeiras. Um quebra-cabeça, necessidade de otimizar o uso do espaço do veículo que não é planejado para atender tantas necessidades. Assim é realizada a grande maioria dos passeios. Os próprios usuários dos equipamentos orientavam os rapazes para reduzir o tamanho das cadeiras, que foram ajeitadas ao lado dos bancos e no fundo da van. No retorno, a necessidade de ajeitarem-se da mesma forma como vieram. (Passeio 005/2008, em 30/03/2009, SESC Interlagos, show da Zélia Duncan) 
A criação de estratégias para a superação de barreiras físicas vão além das ações que constituem os passeios em si, envolve o planejamento, a escolha dos locais e muitos detalhes capazes de abrir possibilidades:

\section{DSC Grupo I}

Quando ia escolher um parque para ir, perguntávamos: "Você conhece?". "Ah, conheço". "E aí, como é lá??". Porque não adianta você falar assim: "Ah, eu consigo levar um grupo de deficiente para determinado parque...”. E não consegue porque não tem estrutura. Tem a estrutura numa parte. Na parte bonita do parque você não consegue levar porque não vai cadeira. Você não consegue também carregar todo mundo no colo. Você não tem estrutura pra isso.

Muitos teatros têm espaço na primeira fileira pro cadeirante. Mas se você leva um grupo de cinquenta cadeirantes não cabe. Não tem teatro que vai comportar cinqüenta cadeiras ali na frente. E outra, dependo da peça, eles querem interagir. Como que vai interagir, só vai interagir com os que estão na frente? Então você tem que ter o bom senso de conhecer e, quando ligar, perguntar: "Tem espaço para isto? Tem banheiro próximo?". Porque tem, ainda tem lugares que não tem banheiro acessível, não tem uma rampa, não tem elevador.

Como a gente foi num teatro que é acessível até a porta de entrada. Pra você sentar nas poltronas não é acessível. A cadeira não vai. Então se você tem cinquenta pessoas de cadeira, são cinquenta pessoas que você tem que ajudar a se locomover até as poltronas. Você tem que chegar sempre com uma ou duas horas antes. Você, antes deles entrar, você tem que entrar para visualizar o lugar, porque você é os olhos deles. E já marcar: "Olha, esse lugar é acessível para todo mundo”. Não dá... Ou, senão: "Vamos espalhar um pouco, porque dá pra espalhar...". 
Superar as barreiras físicas não implica apenas transpor o obstáculo à frente. A Equipe de Apoio buscou, no relato apresentado, olhar o espaço como um ambiente constituído, também, das relações que se estabelecem entre as pessoas presentes naquele lugar. Assim, construíram estratégias que favoreciam a circulação dos sujeitos e o encontro entre as diferentes formas de ser.

As ações da Equipe de Apoio costuram possibilidades, tecendo atos e situações nos espaços, para que as pessoas com deficiência participem das dinâmicas sociais onde se encontram. Dessa forma, o tecido relacional ganha novas texturas, relevos ou cores e é recriado a partir destas diferenças.

Os integrantes da Equipe de Apoio são atores deste processo que se deixam afetar pelas relações estabelecidas com os participantes e seus modos de ser.

"A gente ajuda a pessoa com deficiência naquilo que ela solicita para a gente. Então às vezes você pega no braço da pessoa "Vou ajudar você a atravessar a rua!". E a pessoa nem quer ajuda, nem precisa de ajuda naquela hora. Então a gente foi aprendendo de acordo com aquilo que eles nos solicitavam e eu aprendi com eles, "Olha não é assim, é assim, é desse jeito. Olha você vai conduzir o cego dessa forma". Eles mesmos ensinavam, começavam a ensinar a melhor forma de ajudar". (Entrevista nำ)

Este deixar-se afetar favorece-lhes criar as estratégias inovadoras que ampliem os atos cotidianos e o envolvimento em situações de participação da população referida. Tais estratégias podem ser muitas, e não dizem respeito apenas à quebra de barreiras físicas: 


\section{DSC Grupo I}

Com as mães, o importante é aproveitar esse momento pra fazê-las trocar experiência. É o momento que elas têm de todos serem iguais, de colocar pra fora as dúvidas que ela têm, sabe? Principalmente trocar essa experiência: "Ah, mas como você faz isso? Como você conseguiu colocar na escola? O meu estuda numa escola especial, eu morro de medo de tirá-lo de lá”. E um monte de problemas que elas têm.

Com os mais jovens, a gente chega em vários lugares que eles interagem também, coloca eles para participar. Começa a fazer perguntas pra eles, para aqueles que falam, eles começam a gritar.. Participar.

Quando tem adolescente, adulto, durante o trajeto, a gente conversa assuntos que essas pessoas não costumam conversar por estarem sempre em família. Não que se fale besteira, não é nada disso. Mas você está do lado da sua mãe, você não vai brincar que você está namorando com o fulano. E eles precisam destas conversas.

Se eu convido um cadeirante que nunca foi, eu então tento chamar um cadeirante que está acostumado a ir, pra que eles troquem, sem que um saiba da situação do outro. Eu não comento nada da situação do outro. Eu estou levando pra trocar experiência.

As intervenções apresentadas no DSC atuam convocando as pessoas com deficiência a colocar-se em situação de participação. Um duplo movimento se processa na criação de oportunidades para participar e no envolvimento com tais oportunidades. Partindo da facilitação, com estratégias macropolíticas de favorecimento do acesso, constroem-se na situação as ações micropolíticas (Rolnik, 2008). Essas se configuram como apoio, suporte, in- 
centivo, com poder de impulsionar o movimento de colocar-se em situação de participação.

"A primeira experiência é, vamos dizer assim, assistida. Que tem esse Apoio. Porque tem a vergonha, tem a dificuldade, tem um monte de coisas”. (Entrevista no2)

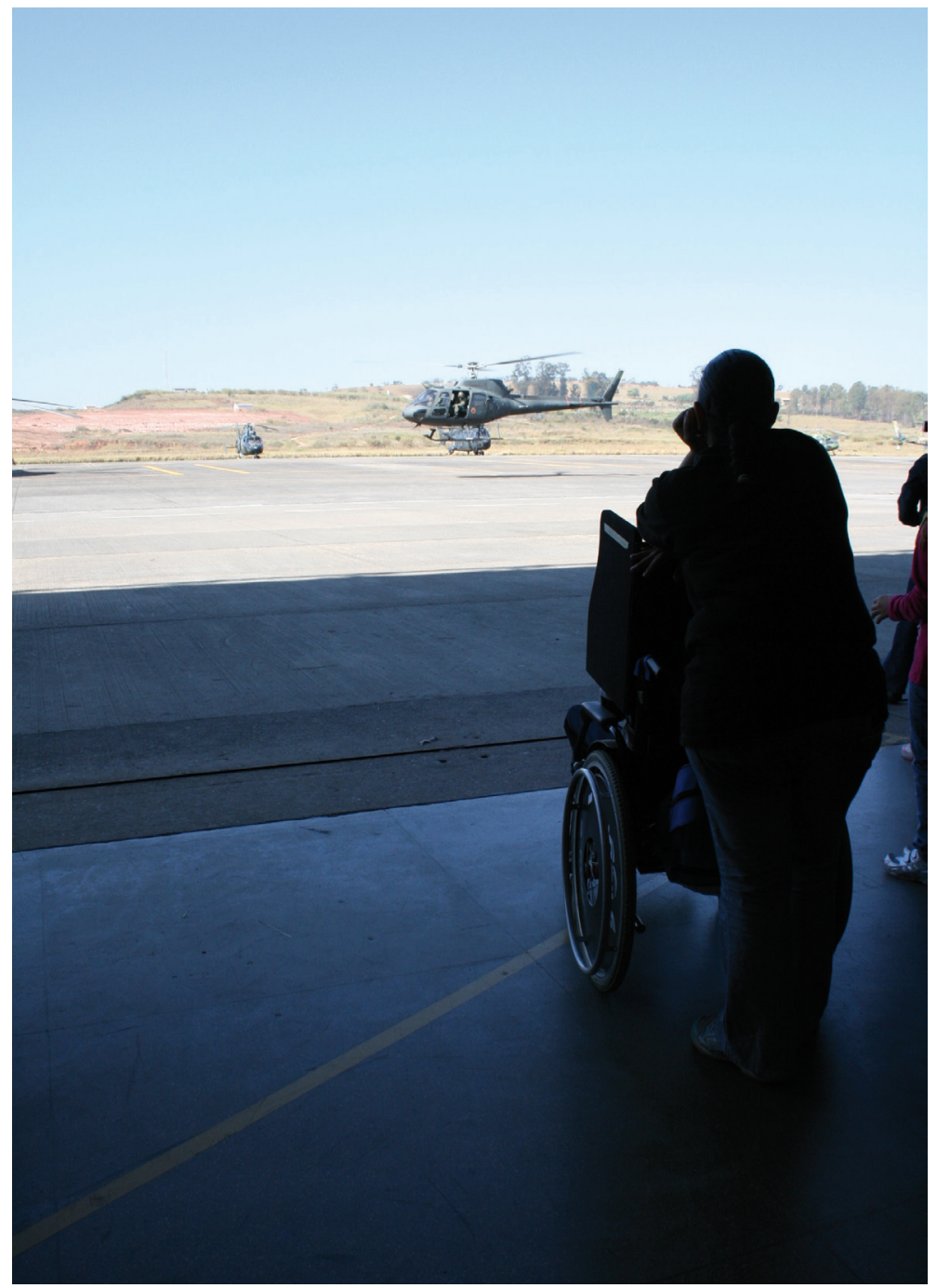

Foto 22 - Participantes do Projeto Andanças observando o pouso de helicóptero na Base do Exército de Taubaté, passeio em 2009.

Os sentidos que direcionam a construção de possibilidades de participação, para as pessoas com deficiência, mostram-se repletos de afetos nas 
atividades do Projeto Andanças. O envolvimento afetivo e subjetivo dos participantes e da Equipe emerge sob forma de palavras que, na maioria das vezes, parece não conseguir expressar com exatidão os sentimentos e as percepções correspondentes à experiência. Assim, orientou-se a criação de um trecho onde o assunto pudesse ser explorado.

\subsection{Envolvimento Afetivo e Subjetivo}

"Eu esqueço que eu tenho deficiência quando eu estou no Andanças, porque eu fico muito preocupada e com vontade de fazê-los trocar essa experiência pra seguir em frente" (Entrevista $\mathrm{n}$-9).

O trecho em epígrafe foi retirado da Entrevista $n^{\underline{o}}$ 2, realizada com uma das idealizadoras do Andanças, voluntária na GPPPD e presidente do Movimento de Apoio à Pessoa com Deficiência no Município. Ela, inicialmente, acompanhou muitos passeios como integrante da Equipe de Apoio, e a frase pronunciada durante a entrevista aponta o desejo de criar oportunidades de envolvimento entre os participantes.

O desejo produzido na experiência é de ordem imaterial: sentimentos e afetos que mobilizam para tecer as relações entre os participantes durante as atividades do Projeto (Hardt, 2003).

Este tema surge no contato com o material analisado, diante das falas - especialmente em entrevistas - sobre uma grande importância atribuída ao Projeto Andanças pelas pessoas que dele participam. Duran- 
te um dos passeios, a mãe de dois participantes relata "a importância do Projeto na vida dela, pois assim tem como sair com 'os meninos', já que não possui condições financeiras para proporcionar lazer para eles". (Diário de Campo, passeio 003/2008, em 09/02/2008, SESC Santo André, show de Zeca Baleiro).

\section{IC - Os passeios com o Andanças deixam marcas nas pessoas}

O DSC do Grupo I fala sobre as marcas deixadas pelos passeios e como estas geram novos pensamentos e ações em relação à continuidade do Projeto:

\section{DSC grupo I}

O primeiro passeio de jipe, e isso também disparou a vontade de fazer uma coisa mais permanente. E cada passeio que a gente vai tem uma marca. Isso significa muito para mim, significa você poder ajudar... Isso é gratificante, meu trabalho é gratificante! E no Andanças, o que a gente queria era fazer a coisa andar e fizemos. Mas que impressiona, impressiona. Olha que... Eu não sabia que eu tinha tanta idéia na minha cabeça como quando surgiu o Andanças...

No Grupo II, as marcas aparecem como elementos sobre os quais não se encontram palavras para dizer a respeito, como se constituíssem experiências que ficam impregnadas no sujeito e, para conhecê-las, é preciso vivê-las. 


\section{DSC Grupo I}

Eu acho que fica marcado. É muito importante pra mim. Eu sei lá, eu tenho um carinho muito grande. O passeio já é uma diversão que a gente jamais vai esquecer. E a gente poder também compartilhar disso tudo, é magnífico. É maravilhoso, só quem participa sabe como que é esse projeto.

As marcas configuram algo que fica após a experiência com o Projeto Andanças. Tomando o pensamento de Rolnik (2008), poder-se-íam defini-las como registros dos efeitos do estado do mundo na sensibilidade das pessoas, quando eles causam um estranhamento. A partir destas marcas, instaura-se a necessidade de inventar novos gestos e ações nas práticas do Projeto Andanças, de forma a integrar os efeitos causados pelo estranhamento, pelas forças da alteridade, no cotidiano de cada um dos sujeitos. Configura-se como um motor que gera o movimento das ações do Projeto (Rolnik, 2005).

\section{IC- Os passeios acontecem com muita alegria}

O Grupo I fala também da alegria que observam nos momentos de participação, decorrentes dos passeios realizados:

\section{DSC Ggrupo I}

Os passeios são superalegres. É uma festa. A gente vê a alegria das pessoas que vão passear, a importância que é tudo isso. Me chama a atenção a alegria que essas crianças entram no transporte, porque elas sabem que vão ter um dia ótimo, 
que elas vão se divertir, que vão passear. Então elas já entram sorrindo, você vê a alegria na "cara" deles, no sorriso principalmente das crianças. É gratificante você ver a alegria, e só de você estar num lugar, para ter uma ideia... No aquário, em Santos, você vê as crianças abrirem os olhos para ver aquele tamanho de um peixe e você está empurrando cadeira de roda e ver a expressão da criança, ou do adulto mesmo que nunca viu. Aquilo lá, para a gente mexe muito. Então é onde dá mais prazer de estar indo mais vezes. Foi emocionante demais! Você descobrir e ver eles descobrindo. Porque eles descobrindo e a gente descobriu eles! Mais ainda...

A alegria apontada pela Equipe de Apoio do Projeto Andanças, os participantes e familiares referem ser decorrente das oportunidades de participação que são criadas, de conhecer coisas novas, de poder envolver-se em situações ainda não experimentadas:

\section{DSC Grupo II}

Os passeios fazem a gente viver mais, ver coisas diferentes. É pra você parar e rever tudo, todos os seus valores. Eu gostei muito.

Eu gostaria que este momento nunca acabasse. Porque foi o passeio que deixou o meu filho muito feliz. E a mim também, de acompanhar e conhecer pessoas, conhecer lugares que eu não conhecia. E quando teve o passeio que as pessoas com deficiências participaram e se sentiram felizes. Se sentiram assim, fazendo parte. Parte, assim, do todo. Porque geralmente a vida de uma pessoa com deficiência é uma vida à parte.

Essa alegria aponta para os "bons encontros" proporcionados pelo Projeto Andanças, momentos em que os afetos e emoções em relação ao que é 
deficiência são reconfigurados. Nos bons encontros, a alegria afeta a todos que entram em contato com a experiência, aumentando a potência de agir: as pequenas soluções construídas e encontradas nas práticas cotidianas com essas populações, que possibilitam a ressignificação da deficiência e da participação social dessas pessoas (Rocha et al., 2003; Spinoza apud Deleuze, 1978).

Para Spinoza (apud Deleuze, 1978), a existência é caracterizada por uma variação contínua da força de existir ou da potência de agir, o que ele denomina afeto. Alegria e tristeza são paixões fundamentais, dois polos que envolvem, respectivamente, o aumento e a diminuição da potência de agir. $\mathrm{O}$ termo afetivo aqui utilizado não se refere apenas à variação dos sentimentos suscitados na experiência com o Projeto Andanças, mas, principalmente, direciona o olhar para a alegria causada.

Rememorar a experiência com o Projeto Andanças, nos relatos, causou uma emoção que parece refletir o envolvimento afetivo com a vivência. Após a digitação e envio das Entrevistas, uma das entrevistadas entrou em contato com o pesquisador, para relatar sobre a emoção vivida ao ler o material recebido e agradecer essa experiência. Alegria que aumenta sua potência de agir.

Nessas experiências, os gestos são carregados de uma carga afetiva que impregna a memória. Como na experiência da artista Rivane Neuenschwander com o Projeto Axé, ${ }^{48}$ relatada por Ronik (2000), as barreiras identitárias que separam, neste caso, pessoas com e sem deficiência, no imaginário são derrubadas. A tensão dos conflitos sociais que trava o afeto é desmanchada na intervenção realizada pelo Andanças, nas pequenas ações onde houve efetiva

${ }^{48}$ Rolnik (2000) relata em seu texto Quarar a alma o trabalho realizado pela artista Rivane Neuenschwander durante a parceria entre o Projeto A Quietude da Terra e o Projeto Axé. Em sua proposta, Rivane realizou uma intervenção artísticas com jovens em situação de vulnerabilidade social, na qual utilizou materiais habituais do cotidiano para problematizar a situação de rua em que vivem muitos deles. 
troca de experiência, nos momentos mais fugazes, desprogramados, espontâneos. Os gestos do Projeto em relação a seus participantes constituem espaços para eles e "demarcam territórios de existência, aquilo que provê um sentimento de si e a possibilidade de inserção no mundo" (p.8).

Entendendo a subjetividade como processo, constituída por um conjunto de forças que entram permanentemente em jogo, criando, a todo momento, diferentes configurações de subjetividade, as ações promovidas pelo Projeto Andanças compõem um destes campos de força. Dessa forma, dão visibilidade aos diferentes modos de ser (Coelho, 2005; Rolnik, 1995).

A visibilidade das diferenças propostas pelo Projeto Andanças entra em choque com a busca por um traço identificatório nas relações sociais que, habitualmente, se busca na contemporaneidade. Dessa forma, desperta o olhar para a singularidade, possibilitando que as pessoas, de fato, possam se encontrar: reconhecer as diferenças que compõem a relação estabelecida, vivenciando a experiência da alteridade no cotidiano (Batista, 2004; Dubet, 2010; Rolnik, 2010).

\subsection{Alteridade}

A dinâmica entre cenas e olhares produzida pelo Projeto Andanças é um dos elementos fundamentais para dizer sobre as relações com as diferenças. Para Calvino (1990), a visibilidade constitui um dos valores fundamentais para a literatura, ${ }^{49}$ e tomam-se, aqui, suas palavras, para problematizar as diversas cenas apresentadas pelos entrevistados.

${ }^{49}$ Calvino (1990) elege a leveza, a rapidez, a lentidão, a visibilidade e a multiplicidade como qualidades da escrita, a serem transmitidas para as próximas gerações. 
Podemos distinguir dois tipos de processos imaginativos: o que parte da palavra para chegar à imagem visiva e o que parte da imagem visiva para chegar à expressão verbal. O primeiro processo é o que ocorre normalmente na literatura. (...) somos levados a ver a cena como se esta se desenrolasse diante de nossos olhos.

No cinema, a imagem que vemos na tela também passou por um texto escrito, foi primeiro "vista" mentalmente (...). Esse "cinema mental" funciona continuamente em nós e sempre funcionou, mesmo antes da invenção do cinema - e não cessa nunca de projetar imagens em nossa tela interior.

Seja como for, as soluções visuais continuam a ser determinantes, e vez por outra chegam inesperadamente a decidir situações que nem as conjecturas do pensamento nem os recursos da linguagem conseguiriam resolver. (p.99, 106)

Através das imagens, construídas pelas fotografias e por narrativas, o Projeto Andanças convoca olhares para a cena e constrói (ou desconstrói) ideias, valores, pensamentos... Muitas cenas foram descritas nas entrevistas, como um convite a participar daquele momento e viver a mesma emoção daquele que narra.

\section{IC: As imagens mobilizam olhares}

Ao chegar aos locais dos passeios, o Projeto Andanças, em geral, causa um impacto, chamando para si muitos olhares. Diluídos na multidão, os participantes se destacam, assim como o grupo reunido de pessoas com deficiência. 


\section{DSC Grupo I}

Nós levamos um grupo de pessoa com deficiência não para um espetáculo de pessoas com deficiência. Então, nós organizamos grupo de pessoas com deficiência para estar em espetáculos que tem 2000 pessoas, trezentas pessoas, quatrocentas pessoas. Eles se diluem na multidão. Causa um impacto quando se vê. Porque as pessoas estão acostumadas a passar pela rua e encontrar uma pessoa com deficiência. De pegar o trem e ver uma pessoa com deficiência ou duas. Agora, você sai de casa com a sua família para se divertir, para ver um show, para ver um espetáculo de circo e então você chega em um lugar e encontra um grupo de pessoas, um grupo grande de pessoas com deficiência. São várias pessoas com deficiência reunidas, isso chama a atenção em qualquer lugar. As pessoas olham mesmo, mas olham por ser um grupo, não é uma coisa comum. Você não está acostumado a ver um grupo de pessoas com deficiência.

A partir do primeiro contato, a cena inicial constituída com a chegada do grupo, o olhar para a situação torna-se mais atento, sensível para os pequenos gestos e para a presença dessas pessoas no espaço social. A chegada do grupo constitui-se, então, como a primeira estratégia que sensibiliza aos que olham a cena.

\section{DSC Grupo I}

É muito simbólico você chegar com um grupo de vinte pessoas com deficiência, das mais variadas deficiências de uma vez, numa casa de espetáculos. Você vê, que espanta. Tem aqueles que se chocam em ver. Quer ficar, assim, meio afastado porque acha que deficiência assim pega. Você vê vários olhares dos outros espectadores. Tem 
aquele que olha assustado, aquele que olha: "Que legal!". Aquele que olha: "Coitado!", "Ai, você quer que ajude?". Você tem todos os olhares. E são os olhares da sociedade. Muitos não olham pro lado da deficiência, eu sempre percebi isso. Eles não olham pelo lado da deficiência. Eles olham assim pelo lado da pessoa assim, do conhecimento mesmo. Eu não vejo isso como preconceito, as pessoas não olham feio, não descriminam, mas você percebe que olham sim, que acham diferente.

\section{DSC Grupo II}

Tem gente que olha assim: "Meu Deus do céu! Que absurdo é esse, eles são loucos! Saindo com esse monte de retardado junto!”. No teatro nós fomos, quando nós chegamos, tinha bastante gente. As pessoas quando viram os excepcionais ficavam abismados. "De onde saíram essa gente?". Mas tem outros que olham assim: "Nossa, meu Deus! Que lindo! Eles estão enfrentando tudo e estão aqui junto!”. Há sempre os dois lados perfeitamente, é bem interessante isso. Tem gente que vem de cara pronta pra te ajudar, pra te dar a mão. Tem uns que têm medo de pegar a sua doença.

Como são muito mais pessoas com deficiência, então chegava aquele grupo, aquelas outras pessoas que estavam lá, ficavam tudo, assim... Olhava, ficava prestando atenção.

Com o convívio a gente aprende que se a gente não enfrentar o olhar, o olhar não vai mudar nunca. Apesar daquele primeiro impacto que as pessoas olham, aí depois quando elas começam a conviver o olhar muda. Isso é só. O primeiro contato no Andanças que você sai, você vai, você vai pra um lugar novo, que nem o teatro. Então a peça de teatro não vai ser só pra pessoa com deficiência, eles vão participar com outras pessoas. Quando você chega, as outras pessoas olham assim e ficam com um pouco de receio. Mas depois, quando começa a peça de teatro, quando começa a 
interagir, eles começam, a ver que não tem nada de diferente. Então está todo mundo ali, junto num ambiente só, sem nenhum problema, sem nenhuma diferença. E aí, aquele olhar muda, porque as outras pessoas aceitaram e os familiares começam a se sentir à vontade, porque está todo mundo ali junto sem nenhum problema maior, entende? Nenhuma palavra de desconforto, que aí começa a convivência e as pessoas com deficiência começam a ter contato, então eles começam a não se sentir tão retraídos, com medo, porque geralmente quando ficam muito em casa eles não têm contato, então, fica difícil lidar com outras pessoas.

Depois de serem impactadas pela presença do Projeto Andanças e convocadas a olhar, as pessoas sem deficiência que circulam no espaço social mostram-se atentas e curiosas para o que se passa, às vezes, aproximando-se do grupo de deficientes, às vezes, mantendo olhar atento e curioso. Parte-se de um estranhamento, algo diferente que se coloca na cena e chama a atenção, da qual é difícil desviar o olhar.

A percepção de que são olhados é um consenso entre participantes e equipe. Mas o próprio grupo, que gera e possibilita a criação de cenas inusitadas, observa, entre as imagens que produzem, situações que chamam também a sua atenção.

\section{DSC Grupo I}

O que a gente vê são cenas muito interessantes. A M., uma criança com paralisia cerebral. Com uma garotinha, brincando. Numa construção de relação superlinda! Arrepia de lembrar! Uma criança brincando com a outra, normal. Eu falei: "Gente olha que gostoso você ver isso, a união!". A criança podia estar em 
casa e os dois sentadinhos na escada conversando. E a avó dizendo assim: "Nossa, ela nunca teve contato com uma criança numa cadeira de rodas...". E elas tinham a mesma idade, e tudo mais. E isso a gente olha e a gente vê que os funcionários vão olhando, vão buscando outras coisas.

"O que marca a gente assim é um deficiente empurrando o outro. Você vê assim, duas cadeiras de rodas, um consegue manejar a cadeira empurra o outro que não consegue. Uma pessoa com duas muletas também, fica apoiando e tentando empurrar. Então essas coisas a gente fotografa". (Entrevista n⿳004)

As cenas que saltam aos olhos dizem da relação entre pessoas com e sem deficiência, da dinâmica entre as diferenças. Esta parece produzir imagens diversas daquelas que estamos habituados a ver no cotidiano. As diferenças subjetivas em relação provocam curiosidade: os gestos e soluções para as situações colocadas podem ser muito diferentes daqueles que são adotados no dia a dia.

"Você vê que as pessoas tão passando por cima de muitas limitações, e outras estão querendo te ajudar, entende? Ai, você olha para o lado, tem uma criança toda autista, toda bobona, coitada, e sentindo o vento na cara. O dia que a gente foi na praia... Aquele dia assim, eu prestava atenção, mais no horizonte do que tava acontecendo ao redor, tipo: era mãe esticando a canga pra deixar o filho embaixo do guarda-sol, porque eles tinham a pele muito fininha, não podia ficar. Ai a outra autista queria sorvete, ela se melava toda, passava sorvete em tudo, menos na língua, mas ela tava sentindo aquele cheiro da maresia, sentindo aquela brisa. O outro cadeirante vai, larga a cadeira lá no comecinho da água e entra de bunda, se arrastando na água. 
Você vêe, são pessoas passando por cima de tantos obstáculos. Um fortalecia o outro. São pessoas tão graves, mas um fortalece o outro. Você nem lembra de olhar a cor do biquíni. Você fica admirando tanto aquelas coisas”. (Entrevista no8)

O olhar admirado para as diversas situações encontradas pelas pessoas com deficiência leva ao risco de valorizar a necessidade de superação das condições encontradas, como somente um gesto grandioso, que deve ser visível a todos, como, por exemplo, quebrar a escada e construir uma rampa. É necessário o cuidado para não cair na ideia que esta ação por si torna o ambiente acessível para aqueles que tem um comprometimento de mobilidade. Nota-se a necessidade de atentar para as respostas encontradas nos pequenos gestos e trazê-las, também, para a visualidade, de forma que é necessário deter o olhar por um tempo maior se quisermos conhecê-los.

As cenas, muitas vezes, inusitadas são criadas na própria circulação das pessoas com deficiência, colocando-se em situação de participação. O trecho, a seguir, relata o movimento dos participantes do Projeto Andanças num dos passeios realizados. A organização do evento havia separado um lugar exclusivo para que pessoas com deficiência, idosos e acompanhantes pudessem acompanhar o show musical sentados, entretanto, o local escolhido para as únicas cadeiras na plateia não possibilitava visualizar o palco com todo o restante do público em pé (Diário de Campo, 2008):

"Quando o show começou, segui mais para o meio da multidão com E. e W. e pedi que ele dissesse até onde seria possível seguir. Ele não sinalizou, mas não fomos longe. W. tem um olhar enigmático: olha para 
tudo ao seu redor, mas não diz sobre as coisas que parecem passar em sua cabeça (que parecem muitas).

No meio da multidão, viam-se outros deficientes em cadeira de rodas, circulando com pessoas sem deficiência, em pequenos grupos.

Já não era mais possível ver os que estavam sentados (devido à multidão), quando E. aproximou-se mais do palco. Eu e W. ficamos onde estávamos.

Antes do show começar, E. questionou sobre a visibilidade dos cadeirantes e das pessoas que permanecessem sentadas no lugar designado. Durante o show, M. (mãe de W.) veio nos procurar para avisá-lo que o grupo não estava mais naquele local, levando cadeiras para a lateral do palco.

A postura do local em separar um espaço para idosos e deficientes, pareceu uma preocupação com o conforto e mobilidade: o local era próximo aos banheiros e protegido, de certa forma, da aglomeração. Pecou, entretanto no que refere à visibilidade.

Fui com W. acompanhar o show junto aos demais participantes. Das pessoas do grupo, ninguém permaneceu no espaço restrito. Os cadeirantes (e outras cadeiras de plástico) formaram uma fileira na lateral do palco: verdadeira linha de frente. As pessoas que não precisavam ou não quiseram sentar, permaneceram próximo, atrás ou ao lado" (Passeio 003/2008, em 09/02/2008, SESC Interlagos, show do Zeca Baleiro). 


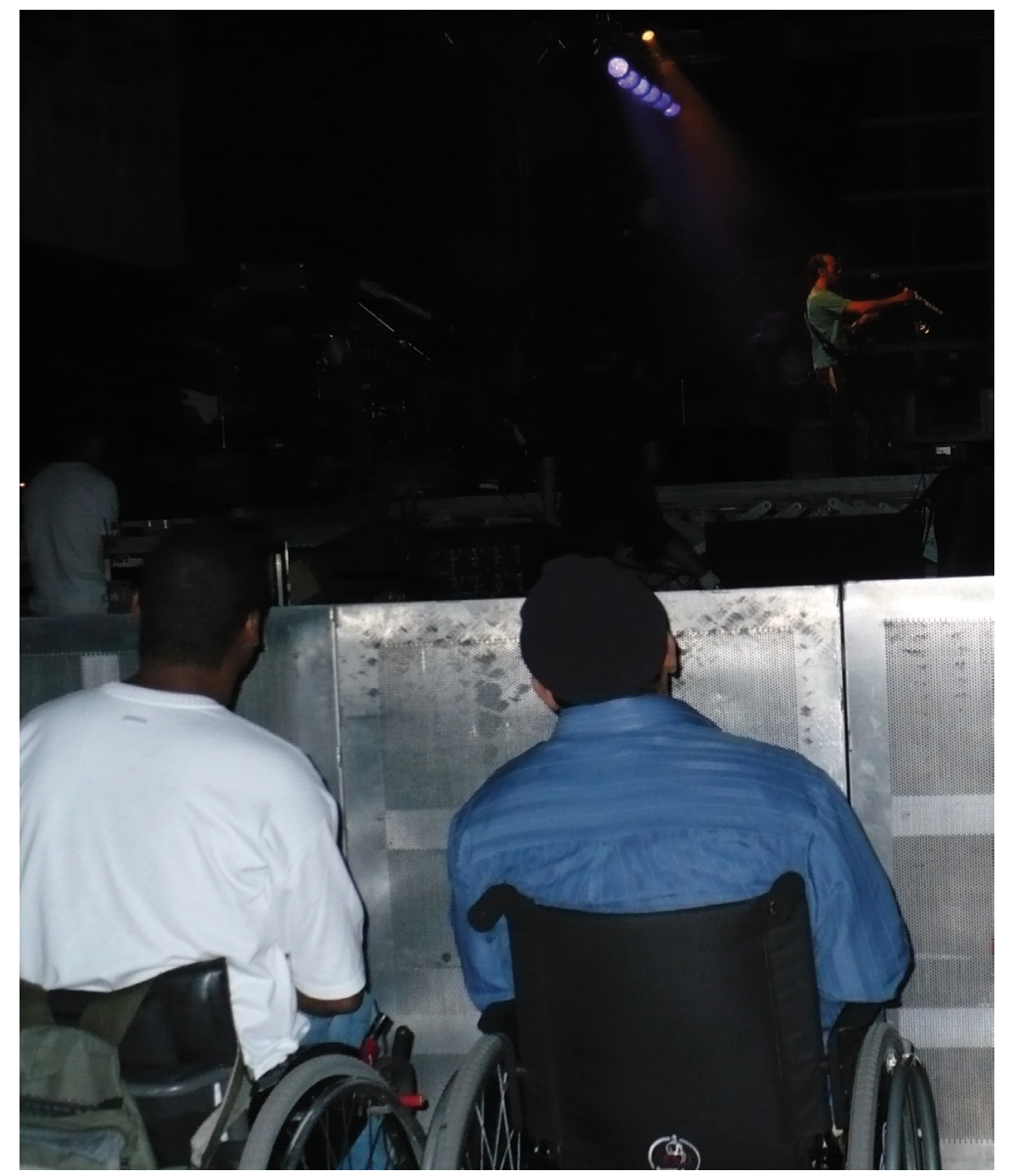

Foto 23 - Participantes do Projeto Andanças no SESC Santo André, show de Zeca Baleiro, em 2006.

A relação com as diferenças é um elemento que aparece em muitas entrevistas. O Grupo I aponta a convivência com as diferenças dos sujeitos participantes como um aprendizado:

\section{DSC Grupo I}

O Andanças não traz só para os participantes, mas para a gente também! Eu, pelo menos, ganhei muito conhecimento. O gostoso do Andanças, da vivência é o seguinte: é o novo e o curioso se juntando, como vai ser. O aprender da gente é esse: a gente olhar e ver o diferente. A gente leva eles pra ver coisa diferente e a gente também vê coisa diferente, neles mesmos. 


\section{DSC Grupo II}

As pessoas até se surpreendem, talvez por não ver bastante gente com deficiência, às vezes, talvez não tenham costume. É só, é só falta de costume, de não conviver com as pessoas com deficiência, porque eles não sabem como lidar.

O discurso do Grupo II parece seguir na mesma direção, a de que um certo aprendizado se dá no contato com as diferenças. Entretanto, utilizam o termo costume: 'sabemos lidar com a diferença se estamos acostumados a ela'. Este pensamento remete-nos à ideia de um conhecimento que se constrói a partir da experiência (Law, 2010).

O contato e a convivência entre pessoas com e sem deficiência mostram-se, assim, essenciais para a construção de uma sociedade aberta às diferenças subjetivas, aos diferentes modos de ser. O aprendizado tácito que se processa na relação com as diferenças é levado para outras situações da vida, através de novos gestos.

\subsection{Conhecimento TÁcito: Relatos Que CAPTAM Gestos}

Muitas das ações desenvolvidas nas atividades do Projeto Andanças não se encontravam sistematizadas ou registradas. Os saberes entre os integrantes da Equipe de Apoio eram transmitidos na experiência e, muitas vezes, a palavra não era o suficiente para descrever as práticas destes facilitadores de participação. Exemplo desta questão pode ser observado em um trecho de uma entrevista, na qual a entrevistada relata sobre seu primeiro passeio e as dúvidas em relação ao trabalho que estaria prestes a desenvolver 
"E daí o que é acompanhante? O que a gente entende por acompanhante? Eu tenho que pegar a criança, tenho que pegar as bolsas? Eu não sei pegar, então era muito assim. É só no viver que a gente entende. Tanto que quando eu fui para o Ibirapuera, era muito engraçado, eu perguntava 'Gente o que eu tenho que fazer, é só eu ficar junto com a pessoa?’. Me disseram que não. Isso foi no primeiro momento, nas primeiras horas, eu perguntava: 'Gente, eu vou ter que pegar bolsa? Eu vou ter que carregar a criança? Eu nunca peguei a criança, será que eu vou conseguir?’. (...) Foi onde a gente aprende a abrir e fechar cadeira, onde a gente aprende a conduzir uma pessoa, e eles mesmos ensinam. Foi quando eu falei assim: 'Bom, isso é mais fácil do que eu imaginava!'”. (Entrevista no 6)

Este saber tácito, ${ }^{50}$ que permeia todo o trabalho do Projeto Andanças, aparece como fundamental para o desenvolvimento das ações micropolíticas que, no Projeto, favorecem a participação social da população que atende. Elas propiciam que os sujeitos envolvidos na situação possam entrar em contato com as diferenças e percebê-las como singularidades que constituem outras pessoas, não como falha ou defeito. Este conhecimento é criado e aprendido na transformação da experiência. Assim, vivenciar situações que coloquem, explicitem as diferenças nas relações, torna-se fundamental para que elas se façam presentes no cotidiano contemporâneo. (Rolnik, 2005; Law, 2010).

Nos discursos construídos, observa-se uma discrepância daquele produzido pelo Grupo I e o representativo do Grupo II. Os participantes e seus familiares apresentam falas mais simples, e uma dificuldade em dizer da experiência, do saber tácito. Para a equipe, o exercício contínuo em trazer esse conhecimento para

\footnotetext{
$\overline{{ }^{50} \text { Para Law (2010) }}$ o conhecimento apresenta três dimensões: o conhecimento tácito (expresso nas ações das pessoas); o conhecimento explícito (que é facilmente comunicável) e o conhecimento cultural (que trata do que é compartilhado).
} 
o explícito (na hora de convidar novos participantes ou estabelecer parceiros), as palavras surgem com um pouco mais de facilidade, ainda que sob a forma de cenas. Um dos membros da equipe questiona:

"Quando eu olho, falo: nossa, por que outras cidades não fazem isso se a gente diz: a tecnologia social está disponível? Ninguém está dizendo é nossa! Não, e ela pode ser adaptada a qualquer lugar. Mas é muito trabalhoso você pensar nisso. A engenharia do projeto é simples, mas o desenvolvimento dele é trabalhoso sim”. (Entrevista $n^{0}$ 1)

Apenas disponibilizar a proposta para outros locais desenvolverem não garante os resultados obtidos com o Projeto Andanças. O mecanismo de funcionamento é, prioritariamente, organizado a partir do conhecimento tácito no manejo com a população atendida e os espaços sociais. Portanto, para replicar a ideia, parece-nos fundamental a experiência junto aos sujeitos que possuem, nos seus gestos, esse saber. Nesse sentido, a continuidade do trabalho, com a sua potência de mobilizar, necessita uma mistura entre aqueles que partilham o conhecimento tácito com aqueles que não o possuem (Rolnik, 2000; Law, 2010).

\section{IC: O Projeto Andanças produz um conhecimento tácito na interlocução entre as pessoas com deficiência e a sociedade}

\section{DSC Grupo I}

Conforme a gente vai desligando e vão entrando outros atores, você vai formando novas pessoas e vai construindo outras redes paralelas. E quando você passa 
isso para um próximo, que você quer deixar que faça o mesmo, ele vai ver que é fácil também. É só você pensar, agir um pouquinho mais que fica fácil. A gente tem que fazer a base, mas passar adiante, e fazer mais cabeças, para mais pessoas participarem. Então a gente vai abrir espaço para que mais pessoas compartilhem da mesma emoção que a gente. O trabalho nisso é isso, é fazer com que mais pessoas se aproximem, se identifique com aquilo.

Para aproveitar, então, a potência deste trabalho enquanto política pública, parece-nos fundamental construir um caminho onde o conhecimento tácito possa ser replicado e, à medida do possível, torná-lo um saber explícito, através do exercício de falar sobre o trabalho, as ações, as experiências vividas.

O sentido de realizar este tipo de intervenção, sob a alcunha de atividades de lazer, é aproveitar do caráter espontâneo deste campo de ação humana para a criação, o aprendizado e a transmissão de conhecimento, especialmente em sua dimensão tácita (Law, 2010).

Talvez, o mais importante conhecimento construído pelo Projeto Andanças trata-se do lidar com as diferenças. Assim, vivenciar os passeios com estes atores produz conhecimentos que serão levados para outras esferas da vida. As pessoas aprendem, então, a lidar com as diferenças, o que possibilita uma abertura para a participação da população com deficiência. O tecido social vai se transformando e sua tessitura ganha outras possibilidades. 


\subsection{O LAZER: DENOMINAÇÃO QUE EMERGE NO CONTATO DO PESQUISADOR COM O OBJETO DE PESQUISA}

O olhar para a questão das deficiências no decorrer do tempo encontra ressonâncias na história do lazer, enquanto elementos que recebem valorações negativas em face da lógica socioeconômica voltada para a produção e reprodução desenfreada do capital. Se a deficiência é vista como desvio das normas e padrões previamente estabelecidos, sendo a sua aceitação condicionada a uma adaptação, o lazer tem valoração positiva, especialmente, quando considerado como elemento que contribui para o processo produtivo, no descanso do trabalhador, possibilitando a recuperação da mão de obra (Dumazedier, 1976).

A valoração para ambas as questões sofre alterações na história. Hoje, a busca de uma valorização social da diversidade e a luta pela aceitação das diferenças possibilita que a deficiência ganhe novas possibilidades de participação social. A associação crescente do lazer à saúde e bem-estar das pessoas, coloca-o em destaque em diversas discussões, incluindo-se aí as intervenções e práticas voltadas para as pessoas com deficiência. As discussões teóricas, que são desenvolvidas em suas respectivas áreas de conhecimento, demoram a constituir um olhar social para a questão, sendo as relações cotidianas atravessadas por diversas conceituações sobre os temas (Gomes e Rejowski, 2005; OMS, 2003).

Quando a questão da deficiência é colocada em pauta, traz consigo uma série de questionamentos em relação aos valores sociais adotados como positivos, como a velocidade e a produtividade. Algumas experiências são colocadas como trajetórias de superação e tornam-se modelos a serem perseguidos 
pelas pessoas com deficiência. Nos momentos em que aparecem desta forma, favorecem a reprodução subjetiva pregada pelo sistema capitalista. Isto facilmente acontece quando se olha apenas para a condição inicial de ser pessoa com deficiência, e achatam-se as experiências do processo em que se construiu a participação social daquele sujeito. São os olhares para as pequenas cenas do cotidiano que constituem protestos contra a subjetividade capitalística, redimensionando as concepções acerca da deficiência (Guattari e Rolnik, 1996; Rocha et al., 2003).

O lazer, assim como a questão da deficiência, tem o olhar sobre si modificado e convive com as diferentes concepções desenvolvidas no decorrer dos tempos. São conceitos, como nas palavras de Deleuze e Guattari (2004; p. 31): "cada conceito remete a outros conceitos, não somente em sua história, mas em seu devir ou suas conexões presentes". O lazer remete-nos à questão da produção socioeconômica, aos valores atribuídos em decorrência dos modelos produtivos, às relações com o tempo, com as concepções de trabalho, à participação social. Tema este, ponto fundamental para a construção realizada nestes escritos.

Nas entrevistas, ou mesmo nos passeios, o lazer é um tema pouco e superficialmente abordado. A questão sequer é mencionada nos registros do Projeto Andanças. No discurso do Grupo I é utilizado para, de certo modo, nomear as práticas deste trabalho.

\section{DSC Grupo I}

A gente não tem uma cultura do lazer. As pessoas veem dessa forma, as pessoas não veem como necessário que as pessoas com deficiência vão ao teatro, ao circo, ao cinema. Então, por ser um lugar de lazer, um momento de lazer, eles verem ali um 
grupo de pessoas com deficiência fazendo a mesma coisa que eles vão fazer, que eles estão fazendo, se divertindo em uma hora de lazer é diferente, as pessoas não estão acostumadas a ver um grupo de pessoas com deficiência se divertindo, se descontraindo, se entrosando junto com as outras pessoas. Assim, é legal. É necessário que a pessoa saia, que a pessoa se divirta, porque acho que isso faz parte da terapia, que isso faz parte do tratamento, se divertir, os horários de lazer. O horário de estar ali com a família, de conhecer outras pessoas, de conhecer outros lugares, de eu não conheço o circo, mas eu vou conhecer, de eu não conheço o cinema, mas eu vou agora, nunca fui à praia, mas eu vou, já me convidaram e eu vou. Então é assim, eu acho que tudo isso faz parte do desenvolvimento da pessoa, porque às vezes a criança sai de casa, vai na fono, vai na hidro, na equoterapia e ai? Só sai de casa para tratamento? Não é assim, acho que tem que sair de casa para o lazer, é específico: "Hoje é nosso passeio, hoje nós vamos sair de casa, mas nós vamos sair para passear, a gente vai sair para se divertir.". Então isso é necessário, extremamente necessário.

Esta menção ao lazer aparece também no discurso do Grupo II, assim como a atribuição de funções ao lazer para o desenvolvimento de pessoas com deficiência. A relação apontada entre lazer e sair de casa indica a importante correlação entre o tema e a questão da participação social dessa população.

\section{DSC Grupo II}

Lazer é diversão. Eu acho que o lazer é muito importante, tanto pra gente como pra eles. Porque a gente estando no lazer, a gente esquece tristeza, esquece coisa ruim, faz a gente viver mais. Não é verdade? Você não fica só dentro de casa pensando... E se você está, vamos supor. em um parque, o que você pensa? Está ali 
se divertindo, você esquece momentos ruins, é isso que eu acho que é lazer. O lazer é muito importante em todas as cidades, principalmente pra essas crianças que não têm conhecimento. Porque eles estando, vamos supor, em um parquinho, está se divertindo, está tendo contato com as pessoas, vendo coisas diferentes, não é? É isso que eu acho. Lazer, sem o Andanças? Nenhum, só televisão... E rádio... É porque quando você não sai... Aqui em casa sou eu, minha mãe e meu filho, um vizinho... Então o lazer é ir pra escola e voltar, e assistir televisão, ouvir uma música, brincar em casa. Mas lazer, lazer mesmo, de diferente nada.

No contato com o objeto de estudo, o tema do lazer emerge como denominação para o trabalho realizado, de forma a expressar suas potencialidades de favorecer a participação social das pessoas com deficiência, com ações que operam em diferentes níveis, micro e macropolítico. O lazer, em seu caráter espontâneo, possibilita a expressão de desejos e formas de ser, as singularidades subjetivas, e assim, recria o universo cultural possibilitando a criação de novas normas, condutas e valores, recria as manifestações cotidianas dos sujeitos na dimensão coletiva da vida. Favorece uma ressignificação da questão da deficiência na dinâmica social. (Amaral, 2009; Marcassa, 2003; Mascarenhas, 2000).

A participação das pessoas com deficiência em atividades de lazer inscreve a imagem dessa população no imaginário social; constrói um novo olhar, favorecendo o cumprimento de normas e leis, trazendo concretamente para a experiência coletiva as discussões que, por vezes, fica encerrada em campos de saberes específicos para a questão da deficiência. 


\section{ConsideraÇÕES FINAIS}

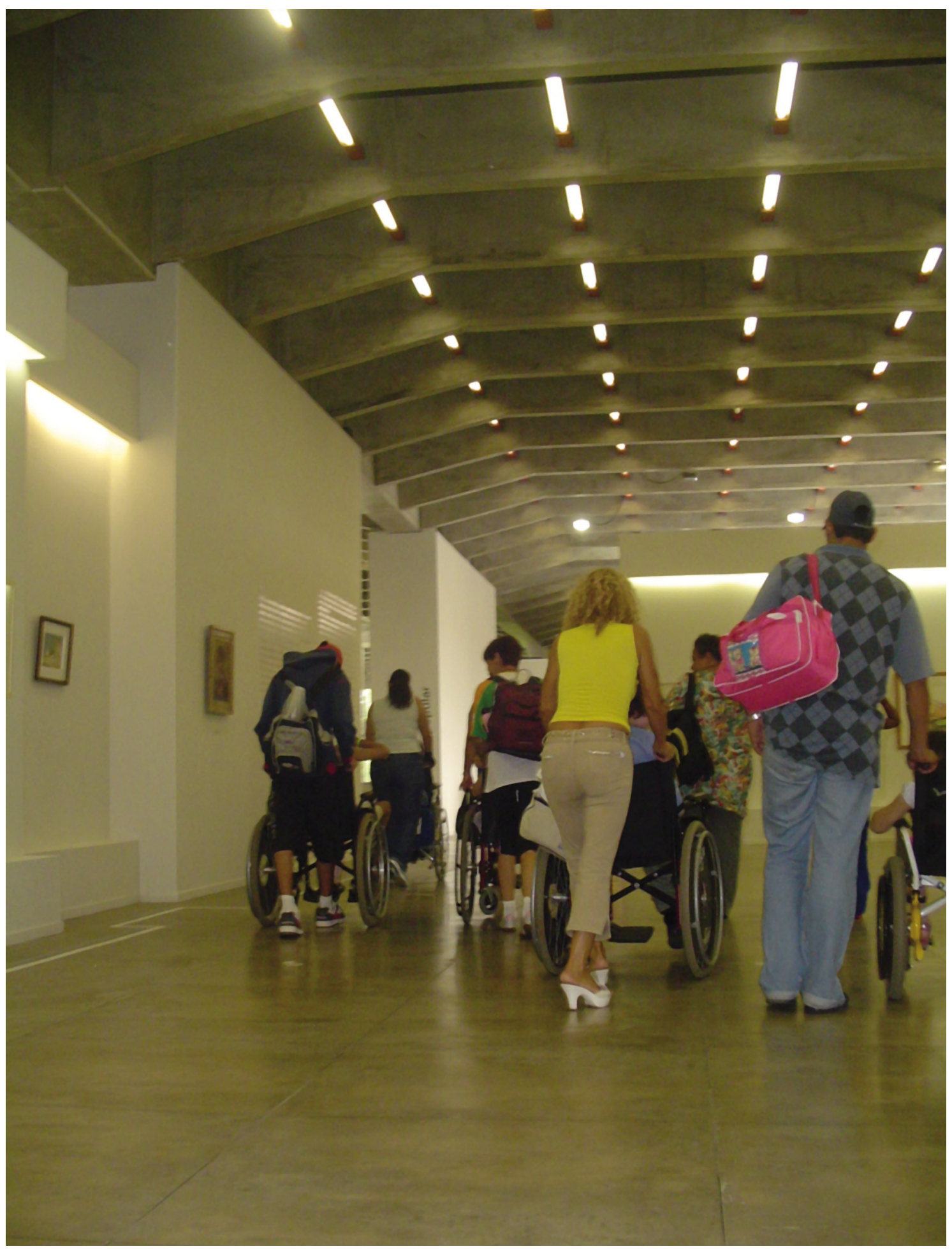

Foto 24 - Exposição Volpi: A Música da Dor - Participantes do Projeto Andanças em passeio ao Museu de Arte Moderna de São Paulo, em 2006. 
O olhar que teceu a construção deste trabalho voltou-se para as sutilezas das ações do Projeto Andanças. Dessa forma, buscou-se trazer à tona as pequenas soluções apresentadas pela proposta estudada: dar visibilidade às ações micropolíticas e apontá-las como importantes vetores de intervenção para a ampliação da participação social das pessoas com deficiência. Sem elas, a proposta macropolítica os perde pontos fundamentais que a sustentam, diminuindo a potência de ação do Projeto. Faz-se necessário ressaltar que a análise realizada não esgotou o material coletado na pesquisa de campo. Foi necessário realizar um recorte e priorizar temas e aspectos a serem discutidos (Rocha et al., 2003; Deleuze, 1978; Rolnik, 2009).

Nos DSC (Discurso do Sujeito Coletivo), o dizível da experiência aparece de forma mais apropriada pela equipe que trabalha a fim de que o Projeto Andanças aconteça. Os participantes parecem não encontrar ou encontrar poucas palavras para dizer do vivido. A Equipe do Projeto, talvez pelo constante exercício de dizer sobre, demonstra uma facilidade maior para falar e expressar percepções e sentimentos a respeito da experiência, mesmo através de relatos de cenas. As soluções visuais aqui se apresentam como determinantes, decidindo situações que não foram possíveis de resolver pelas conjecturas do pensamento ou pelos recursos da linguagem. O exercício de "falar sobre" começa a deslocar o saber tácito para um conhecimento explícito (Calvino, 2006; Law, 2010).

O LAZER, dentro da perspectiva apresentada e junto aos demais elementos da discussão teórica, emerge como possibilidade de trazer o indizível para uma dimensão explícita, ao dar nome para a prática proposta pelo Projeto Andanças. Isto abre um caminho de discussão teórica que recebe contribuições 
de diferentes campos de conhecimento, deslocando as intervenções junto às populações com deficiência do marcador biológico que, historicamente, as constituíram. Esta linha nos estudos sobre deficiência contribui, certamente, para a construção de novos olhares, conceitos e práticas em torno desta questão.

As políticas públicas para as pessoas com deficiência são, muitas vezes, construídas a partir de um olhar macropolítico, procurando intervir nas tensões sociais visíveis e dizíveis. Criam-se nomenclaturas para uma adequação da terminologia em relação às deficiências (construindo caminhos politicamente corretos); quebram-se escadas para a construção de rampas; fala-se de leis e normas de condutas inscritas sob o espectro dos direitos dessas populações. Entretanto, em sua maioria, não há um olhar para a dimensão micropolítica: do invisível e do indizível. Abordar as sensações, percepções e pensamentos suscitados pelo contato com as pessoas com deficiência e construir ações que possam intervir nestas esferas, nas quais atuam as chamadas barreiras atitudinais, configura-se como fundamental para favorecer a participação social dessa população. Além disso, possibilita a criação de um imaginário social que abarque as singularidades nas relações sociais, favorecendo a construção de uma sociedade aberta às diferenças subjetivas.

O Projeto Andanças constitui-se enquanto política pública para pessoas com deficiência e define sua ação macropolítica na facilitação do acesso dessa população "aos bens culturais comuns, através da oferta de ingressos e transporte aos locais dos eventos" (PMETRP, 2006, p.2).

As propostas de intervenções micropolíticas não são especificadas nos registros do Projeto, apesar de ser dito que a Equipe de Apoio tem como objetivo favorecer a participação das pessoas com deficiência nas atividades do 
Projeto (PMETRP, 2006). Elas são construídas na experiência e na relação estabelecida no acontecimento, o que torna difícil enumerá-las e descrevê-las. Somente após o vivido, as cenas tornaram-se palavras e constituíram parte dos dados apresentados nesta pesquisa.

Apesar da dificuldade em nomear e dizer das intervenções micropolíticas, aponta-se para a necessidade de construir políticas públicas, que impliquem tais ações em suas propostas, e, também, a construção de estratégias que afirmem a execução dessas microações. Para tanto, é necessário que os trabalhadores, gestores e o público-alvo das intervenções (no caso, as pessoas com deficiência) compartilhem de uma alegria, de um aumento na potência de seu agir em relação a seus trabalhos e que possam compartilhar suas experiências e, com isso, tornarem-se efetivamente construtores do prosseguimento do Projeto (Spinoza apud Deleuze, 1978).

A pesquisa realizada revela que a construção de ações alegres demanda a atenção para as sutilezas, campo fértil para emergirem as mínimas diferenças. Para isso, é necessário que se tome consciência das variadas formas de gerir o tempo, permitindo a coexistência das diferentes temporalidades. A lentidão é, assim, não mais associada à deficiência, à falta de velocidade, mas como tempo possível para emergências de sutilezas e diferenças (Couchot, 2010; Sant'anna, 2001).

Diante dos aspectos indizíveis e invisíveis das micropolíticas, ressaltase a necessidade de mais estudos que abordem essa dimensão das práticas de participação social, como forma de construir um conhecimento explícito sobre a questão, caminhando para a configuração deste conhecimento como um aspecto cultural (Law, 2010). 
O investimento em ações micropolíticas implica abrir mão da visibilidade das intervenções: são gestos sutis que se diluem na multidão. Mas podem acarretar resultados como os apresentados pelo Projeto Andanças: apesar de visíveis, deparam-se com a dificuldade em teorizar e explicar a simplicidade e o trivial da experiência (Kinoshita, 2001).

Gestos sutis são delicados e fortes, por isso eles se parecem com formigas avermelhadas que andam por toda a parte, como baratas ancestrais, uma sempre seguida da outra. Seres que parecem inúteis nesse mundo de tantas usuras. (Sant'anna, 2001, p. 125)

Os atos cotidianos e o envolvimento em situações da vida são aspectos do fazer humano mutuamente implicados: a ampliação ou redução de um, provoca a ampliação ou redução do outro. Esses elementos constituem a tessitura micropolítica da participação social, ou seja, o invisível do processo (Rolnik, 2008). É através da oportunidade de realizar outros atos cotidianos ou de envolver-se em novas situações na vida que a participação é ampliada. Esse processo é tecido por sutilezas, de difícil visibilidade. É a partir dessa dimensão que as intervenções macropolíticas acerca da participação social são consolidadas, visibilidade construída no processo. 


\section{Anexos}

A - Ficha de Participação nos Passeios do Projeto Andanças

B - Modelo de Registro de Participação nos Passeios - Projeto Andanças (GPPPD, 2006-08)

C - Texto disparador da Entrevista

D - Autorização para estudo do Projeto Andanças

E - Parecer da CAPPesq

F - Termo de Consentimento Livre e Esclarecido

G - Nota de Esclarecimento

H.1 - Autorização do uso de imagem (da própria pessoa)

H.2 - Autorização do uso de imagem (de outra pessoa)

I - Relação de Entrevistas completas 
Anexo A - Ficha de Participação nos Passeios do Projeto Andanças

Prefeifura Municipal da Estância Turistica de Ribeirão Pirus

cabineto.

COORDENADORIA DE POLITICAS PUBUICAS PARA PESSOAS COM DEICIENCIAS DE RIBEIRÃO PIRES

INSCRIÇÃD PARA PROJETO ANDANÇAS

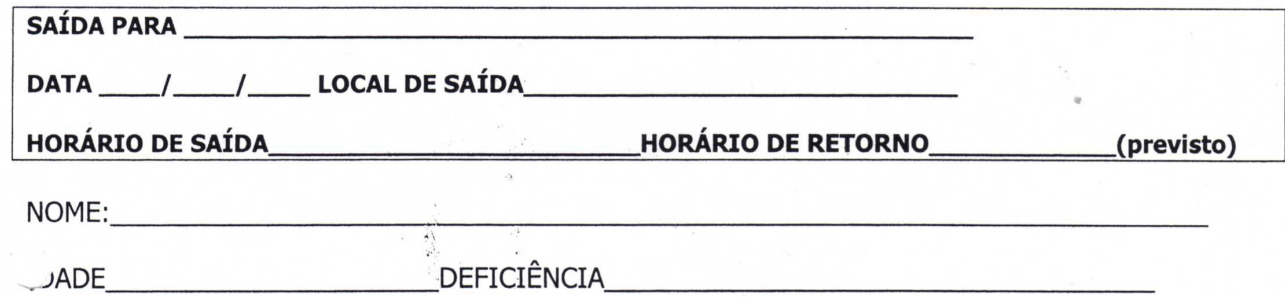

ENDEREÇO:

TELEFONE

INDIQUE O USO DE ÓRTESE OU PROTESE, CASO UTILIZE:

( ) CADEIRA DE RODAS MECÂNICA （ )CADEIRA DE RODAS MOTORIZADAS （）BENGALAS

( )GOTEIRAS ( )APARELHO AUDITIVO ( ) BENGALA LONGA

( ) ANDADOR ( ) MULETAS ( ) OUTROS

NECESSITA DE TRANSPORTE DE CASA ATÉ O LOCAL DE SAÍDA / CHEGADA?

( ) SIM ( )NÃO

ACOMPANHANTE

NOME

PARENTE( ) AMIGO ( )

TELEFONE PARA CONTATO

AUTORIZA O USO DA IMAGEM (PARA JORNAIS, REVISTAS OU OUTRAS PUBLICAÇÕES)?

PESSOA COM DEFICIÊNCIA（）SIM （） NÃO

ACOMPANHANTE ( ) SIM (')NÃO

Assinatura:

data 
Anexo B - Modelo de Registro de Participação nos Passeios - Projeto Andanças (GPPPD, 2006-08)

Passeio (Local do passeio/ Atividade)

\begin{tabular}{|c|l|l|l|l|}
\hline & Nome do Participante & Acompanhante (se houver) & Endereço & Telefone \\
\hline 1 & & & & \\
\hline 2 & & & & \\
\hline 3 & & & & \\
\hline 4 & & & & \\
\hline 5 & & & & \\
\hline 6 & & & & \\
\hline 7 & & & & \\
\hline
\end{tabular}

№ de Participantes:

№ de Acompanhantes:

№ Pessoa da Equipe de Apoio

TOTAL 
Anexo C - Texto disparador da Entrevista

\section{Projeto de Pesquisa \\ Atividades de Cultura e Lazer: Tessituras de espaços para alteridade PESquisador: Cinthia Mayumi Saito}

\section{Roteiro de Entrevista}

Disparando...

O primeiro passeio do "Projeto Andanças: Incluir para mudar o olhar" aconteceu em janeiro de 2006, para a Praia Grande. De acordo com os registros, foram 33 pessoas com deficiência e seus acompanhantes. Tratavase de um grupo grande que, possivelmente, atraía os olhares das pessoas.

De janeiro de 2006 a julho de 2008, foram 47 passeios realizados, na tentativa de levar mais de 200 pessoas com deficiência, a lugares onde pudessem conhecer outras formas de participar de espaços coletivos, onde pudessem mostrar seus modos de vida. Foram ao circo, ao teatro, ao parque, a concertos musicais, deixando boquiabertos os transeuntes que, talvez, nunca viram tantos deficientes ao mesmo tempo. Gente que, em seus momentos de lazer, não esperava se deparar com tanta gente diferente, o que atiçou a curiosidade e a vontade de olhar e de se aproximar.

Sob o olhar das pessoas estão os 'passeadores' que, segundo o dicionário, ${ }^{51}$ são aqueles que passeiam muito ou que gostam de passear. Os participantes do Projeto Andanças são passeadores porque gostam de passear: quando recebem um telefonema dizendo ser do Andanças, logo perguntam para onde é o passeio. Nem todos têm a possibilidade de sair de casa para passear muito. E quando a oportunidade aparece, querem aproveitar ao máximo. Por isso, os passeios acontecem e independem da proposta e do tempo: os participantes comparecem para ir à praia ou passear de jipe mesmo em dias chuvosos. Passear com o Andanças, para aqueles que têm poucos momentos de lazer, é um evento para o qual os participantes levam muita alegria.

${ }^{51}$ Grande Dicionário Larousse Cultural da Língua Portuguesa. Editora Nova Cultural Ltda., 1999. 
Pontos a serem desenvolvidos (voltados para a Equipe):

- Histórico: surgimento e percurso

- O desejo de participar/ fazer parte

- O olhar sobre o Projeto

- A busca/ escolha dos locais

- O convite aos participantes

- Os passeios

- Desdobramento: que efeitos acontecem

Pontos a serem desenvolvidos (voltados para os participantes, familiares e gestores de instituições):

- O convite para a participação

- O desejo de participar/ fazer parte

- O olhar sobre o projeto

- Os passeios

- Momentos importantes

- Desdobramento: que efeitos acontecem 


\section{Anexo D - Autorização para estudo do Projeto Andanças}

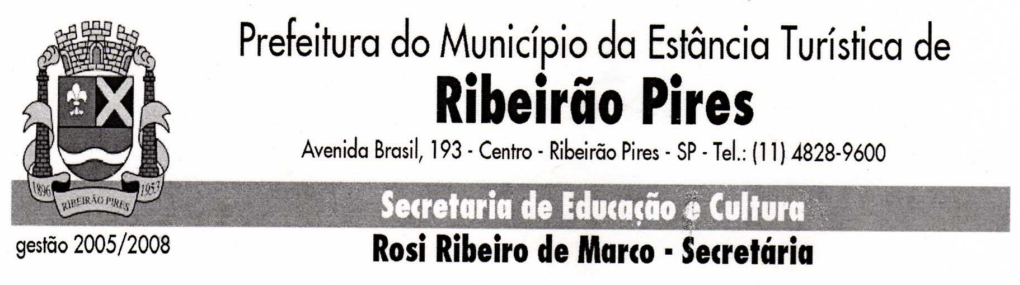

Ribeirão Pires, 23 de janeiro de 2008.

A Gerência de Políticas Públicas para Pessoas com Deficiência, da Prefeitura Municipal da Estância Turística de Ribeirão Pires, coordenadora do Projeto Andanças, autoriza a realização da coleta de dados para a pesquisa de mestrado: "Atividades de Cultura e Lazer: tessitura de espaços para alteridade", a ser realizado durante o decorrer do ano de 2008, por Cinthia Mayumi Saito, terapeuta ocupacional pesquisadora executante da pesquisa, e que consiste nas seguintes ações:

- Acompanhamento dos passeios para adultos do Projeto Andanças; sendo aproximadamente 1 saída/ mês e totalizando, no decorrer de 2008, cerca de 12 passeios;

- Entrevistas semi-estruturadas com os envolvidos no projeto;

- Estudo dos registros no próprio arquivo do Projeto Andanças (análise documental).

Atenciosamente

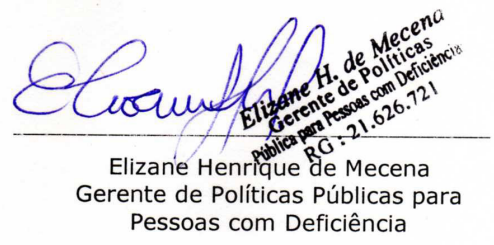




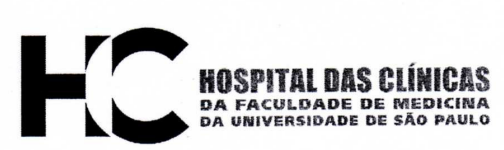

\section{APROVAÇÃO}

A Comissão de Ética para Análise de Projetos de Pesquisa - CAPPesq da Diretoria Clínica do Hospital das Clínicas e da Faculdade de Medicina da Universidade de São Paulo, em sessão de 02/04/2008, APROVOU o Protocolo de Pesquisa $n^{\circ}$ 0143/08, intitulado: "ATIVIDADES DE CULTURA E LAZER: TESSITURAS DE ESPAÇOS PARA A ALTERIDADE" apresentado pelo Departamento de FISIOTERAPIA, FONOAUDIOLOGIA E TERAPIA OCUPACIONAL, inclusive O Termo de Consentimento Livre e Esclarecido.

$$
\text { Cabe ao pesquisador elaborar e apresentar à }
$$

CAPPesq, os relatórios parciais e final sobre a pesquisa (Resolução do Conselho Nacional de Saúde n 196, de 10/10/1996, inciso IX.2, letra "c").

Pesquisador (a) Responsável: Dra. Eliane Dias de Castro Pesquisador (a) Executante: Cinthia Mayumi Saito

CAPPesq, 03 de Abril de 2008



Prof. Dr. Eduardo Massad Presidente da Comissão de Ética para Análise de Projetos de Pesquisa

Comissáo de Ética para Análise de Projetos de Pesquisa do HCFMUSP e da FMUSP Diretoria Clinica do Hospital das Clínicas da Faculdade de Medicina da Universidade de São Paulo Rua Ovidio Pires de Campos, 255, $5^{\circ}$ andar - CEP 05403010 - São Paulo - SP Fone: 0113069 6442 Fax: 01130696492 e-mail: cappesq@hcnet.usp.br/ secretariacappesq2@hcnet.usp.br 
Anexo F - Termo de Consentimento Livre e Esclarecido

\author{
HOSPITAL DAS CLÍNICAS DA FACULDADE DE MEDICINA DA \\ UNIVERSIDADE DE SÃO PAULO-HCFMUSP \\ TERMO DE CONSENTIMENTO LIVRE E ESCLARECIDO
}

DADOS DE IDENTIFICAÇÃO DO SUJEITO DA PESQUISA OU RESPONSÁVEL LEGAL

1. NOME:

DOCUMENTO DE IDENTIDADE No : SEXO : $\quad M \square F \square$ DATA NASCIMENTO: ......................... ENDEREÇO BAIRRO: CEP:. CIDADE

$\mathrm{N}^{\circ}$ APTO: TELEFONE: DDD ( $.$.$) .$

2. RESPONSÁVEL LEGAL

NATUREZA (grau de parentesco, tutor, curador etc.) DOCUMENTO DE IDENTIDADE: DATA NASCIMENTO.: .................... ENDEREÇO: BAIRRO: CIDADE: CEP: TELEFONE: DDD SEXO: $M \square F \square$ $\mathrm{N}^{0}$ APTO:

\author{
CEP:
}

\title{
DADOS SOBRE A PESQUISA
}

1.TÍTULO DO PROTOCOLO DE PESQUISA:"Atividades de Cultura e Lazer: Tessituras de espaços para alteridade"

PESQUISADOR RESPONSÁVEL: Eliane Dias de Castro

CARGO/ FUNÇÃO: Professor Doutor RDIDP

PESQUISADOR EXECUTANTE: Cinthia Mayumi Saito

CARGO/FUNÇÃO: Terapeuta Ocupacional

INSCRIÇÃO CONSELHO REGIONAL N.CREFITO 3 - 8205/TO

UNIDADE DA FMUSP: Laboratório de Estudo e Pesquisa Arte e Corpo emTerapia Ocupacional do Departamento de Fisioterapia, Fonoaudiologia e Terapia Ocupacional da FMUSP.

2. AVALIAÇÃO DO RISCO DA PESQUISA:

$\begin{array}{lll}\text { RISCO MÍNIMO } & \mathbf{x} & \text { RISCO MÉDIO } \\ \text { RISCO BAIXO } & \square & \text { RISCO MAIOR }\end{array}$

3.DURAÇÃO DA PESQUISA: 24 MESES 


\section{Desenho do Estudo e Objetivo(s):}

O objetivo desta pesquisa é estudar a inclusão social de pessoas com deficiências em atividades de cultura e de lazer. Esta é uma questão muito discutida na atualidade, mas observamos que são poucas as iniciativas que envolvem outros setores sociais, além da saúde, e que proporcionem uma real inclusão social. Assim, propomos o estudo do Projeto Andanças, que proporciona atividades de lazer e cultura para pessoas com deficiência e está ligado à Gerência de Políticas Públicas para Pessoas com Deficiência, que trabalha com todas as áreas da Prefeitura de Ribeirão Pires. Nossa proposta é estudar a fundo o Projeto Andanças: como ele acontece, o porquê das pessoas participarem de suas propostas e o que as pessoas acham dele.

2. Descrição dos procedimentos que serão realizados, com seus propósitos e identificação dos que forem experimentais e não rotineiros:

Durante o ano de 2008, proponho acompanhar o mínimo de 12 passeios do Projeto Andanças, direcionados para os adultos, considerando que eles acontecem 1 vez ao mês. O acompanhamento é de fundamental importância para a coleta de informações, e recebe o nome de observação participante, já que proponho estar nos passeios como integrante da equipe de apoio. Esta observação será registrada em diários de campo. A autorização para a observação participante foi concedida pela coordenação do projeto (Gerência de Políticas Públicas para Pessoas com Deficiência). As fotos que geralmente são tiradas no passeio só serão utilizadas se o/a Sr(a) autorizar a publicação.

Alguns participantes poderão colaborar com esta pesquisa através de uma entrevista, na qual conversaremos sobre sua participação e opiniões sobre o Projeto Andanças e será registrada através de gravação em áudio. Esta forma de registro facilita a posterior análise e interpretação dos dados, sem que esses sejam alterados em função das impressões do entrevistador. Após a transcrição da entrevista, o material será lido para o Sr(a), que, poderá então, autorizar o estudo dos dados coletados pelo pesquisador.

\section{Relação dos procedimentos rotineiros e como são realizados}

- Acompanhamento e observação dos passeios do Projeto Andanças;

- Entrevistas individuais sobre a experiência, antecipadamente agendadas em local conveniente ao colaborador. As entrevistas serão gravadas, transcritas e apresentadas para posterior autorização de trabalho com os dados colhidos.

\section{Descrição dos desconfortos e riscos esperados nos procedimentos dos itens 2 e 3 ;}

Para os sujeitos participantes da Observação: Os desconfortos e riscos esperados são os de qualquer observação: timidez ou incômodo com uma pessoa desconhecida (pesquisador). Estas situações podem ser vencidas no diálogo com o pesquisador, assim como por meio de uma atitude compreensiva. À medida que aumentam o número de participações nos passeios, os desconfortos diminuem, tendendo a desaparecer.

Para os sujeitos participantes da entrevista: os desconfortos e riscos esperados são os de qualquer observação: timidez ou incômodo com uma pessoa desconhecida (pesquisador). Estas situações podem ser vencidas no diálogo com o pesquisador, assim como por meio de uma atitude compreensiva. À medida que aumentam o número de participações nos passeios, os desconfortos diminuem, tendendo a desaparecer.

5. Benefícios para o participante

Não há benefício direto para o participante. Entretanto, a discussão teórica realizada a partir desta pesquisa pode:

- Sugerir melhoria e adequações de diretrizes para a implementação de projetos de cultura e lazer.

- Reorientar práticas de profissionais e instituições de saúde, cultura e educação.

6. Relação de procedimentos alternativos que possam ser vantajosos, pelos quais o paciente pode optar: Não há procedimentos alternativos.

7. Garantia de acesso: Em qualquer etapa do estudo, você terá acesso aos profissionais responsáveis pela pesquisa para esclarecimento de eventuais dúvidas. O principal investigador é a Profa. Dra. Eliane Dias de Castro, que pode ser encontrada no Laboratório de Estudo e Pesquisa Arte e Corpo em Terapia 
Ocupacional - Depto de Fisioterapia, Fonoaudiologia e Terapia Ocupacional da FMUSP, localizado à Rua Cipotânea, 51 - Cidade Universitária - CEP: 05360-000 - São Paulo/ SP - Telefone: 11 3091-7456. Se você tiver alguma consideração ou dúvida sobre a ética da pesquisa, entre em contato com o Comitê de Ética em Pesquisa (CEP) - Rua Ovídio Pires de Campos, 225 - 5ªndar - tel: 3069-6442 ramais 16, 17, 18 ou 20, FAX: 3069-6442 ramal 26 - E-mail: cappesq@hcnet.usp.br

8. É garantida a total liberdade: aos colaboradores da pesquisa para retirarem seu consentimento a qualquer momento e deixarem de participar do estudo, sem que seja prejudicada a continuidade de participação nas atividades do Projeto Andanças.

9. Direito de confidencialidade: As informações obtidas serão analisadas em conjunto com outros pacientes, não sendo divulgado a identificação de nenhum paciente.

10. Direito de ser mantido atualizado sobre os resultados parciais das pesquisas, quando em estudos abertos, ou de resultados que sejam do conhecimento dos pesquisadores.

11. Despesas e compensações: não há despesas pessoais para o participante em qualquer fase do estudo. Também não há compensação financeira relacionada à sua participação.

12. Em caso de dano pessoal, diretamente causado pelos procedimentos ou tratamentos propostos neste estudo (nexo causal comprovado), o participante tem direito a tratamento médico na Instituição, bem como às indenizações legalmente estabelecidas.

13. Compromisso do pesquisador: Os dados e materiais coletados somente serão utilizados para a realização desta pesquisa.

Acredito ter sido suficientemente informado a respeito das informações que li ou que foram lidas para mim, descrevendo o estudo "Atividades de Cultura e Lazer: Tessituras de espaços para a alteridade". Eu discuti com a Profa. Dra. Eliane Dias de Castro sobre a minha decisão em participar nesse estudo. Ficaram claros para mim quais são os propósitos do estudo, os procedimentos a serem realizados, seus desconfortos e riscos, as garantias de confidencialidade e de esclarecimentos permanentes. Ficou claro também que minha participação é isenta de despesas e que tenho garantia do acesso a tratamento hospitalar quando necessário. Concordo voluntariamente em participar deste estudo e poderei retirar o meu consentimento a qualquer momento, antes ou durante o mesmo, sem penalidades ou prejuízo ou perda de qualquer benefício que eu possa ter adquirido, ou no meu atendimento neste Serviço.

Assinatura do paciente/representante legal
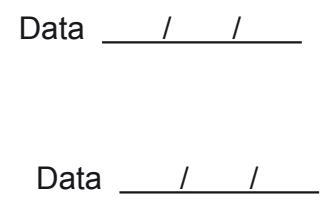

Assinatura da testemunha

para casos de pacientes menores de 18 anos, analfabetos, semi-analfabetos ou portadores de deficiência auditiva ou visual.

(Somente para o responsável do projeto) Declaro que obtive de forma apropriada e voluntária o Consentimento Livre e Esclarecido deste paciente ou representante legal para a participação neste estudo.

Assinatura do responsável pelo estudo

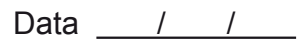




\section{Anexo G - Nota de Esclarecimento}

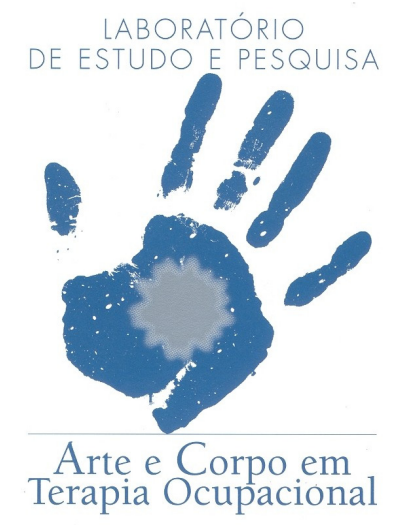

\section{Laboratório de Estudo e Pesquisa Arte e Corpo em Terapia Ocupacional}

Universidade de São Paulo - Faculdade de Medicina

DEPARTAMENTO DE FISIOTERAPIA, FONOAUDIOLOGIAE TERAPIAOCUPACIONAL

Rua Cipotânea, $n^{\circ} 51$ - Cidade Universitária Cep.05360-160 - São Paulo - SP Tel.(11) 3091-8437- Fax. (11) 3091-7415 E-mail: centroto@edu.usp.br

PROTOCOLO DE PESQUISA nº 0143 / 08:

Atividades de Cultura e Lazer: Tessituras de espaços para alteridade PESQUISADOR RESPONSÁVEL: Eliane Dias de Castro

CARGO/ FUNÇÃO: Professor Doutor RDIDP

PESQUISADOR EXECUTANTE: Cinthia Mayumi Saito

CARGO/FUNÇÃO: Terapeuta Ocupacional

INSCRIÇÃO CONSELHO REGIONAL N.CREFITO 3 - 8205/TO

\section{NOTA DE ESCLARECIMENTO}

Esclarecemos a vossa senhoria que as atividades de coleta de dados necessárias para a realização desse estudo são de inteira responsabilidade da Pesquisadora Executante Cinthia Mayumi Saito, com quem será esclarecida e discutida sua participação no mesmo.

À disposição para quaisquer outras dúvidas e esclarecimentos no Laboratório de Estudo e Pesquisa Arte e Corpo em Terapia Ocupacional do Departamento de Fisioterapia, Fonoaudiologia e Terapia Ocupacional da Faculdade de Medicina da USP, localizado na Rua Cipotânea, 51 - Cidade Universitária - CEP: 05360-000 - São Paulo/ SP - Telefone: 11 3091-7456.

Profa. Dra. Eliane Dias de Castro Pesquisador Responsável 
Anexo H.1 - Autorização do uso de imagem (da própria pessoa)
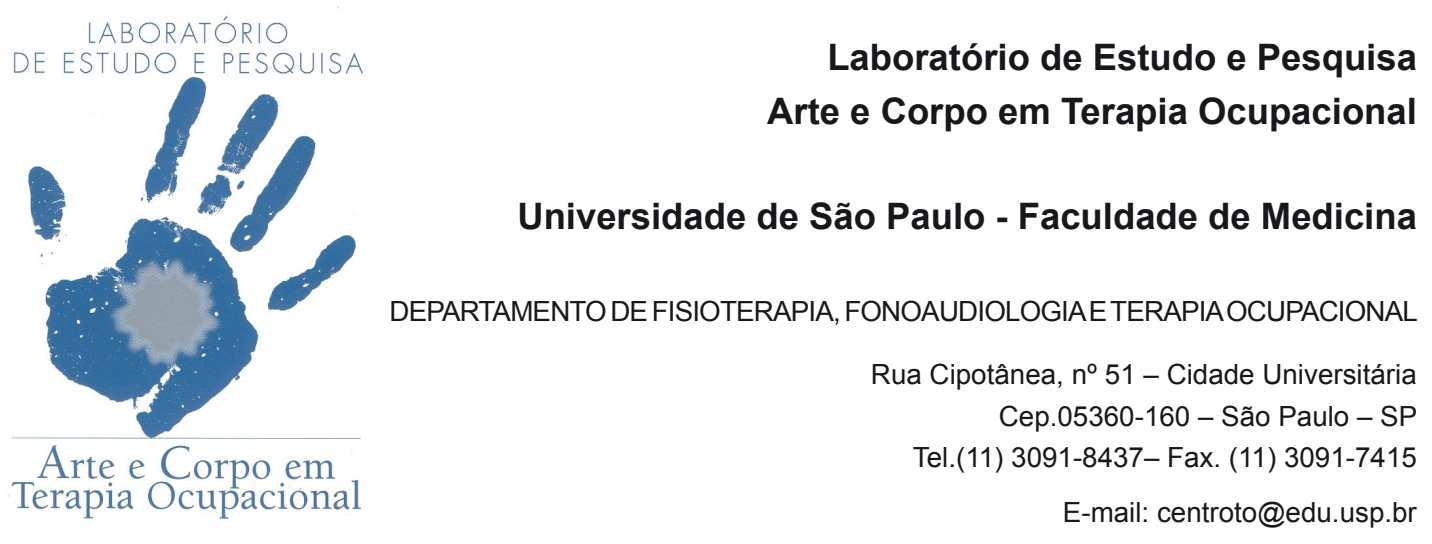

PROTOCOLO DE PESQUISA nº 0143 / 08:

“Atividades de Cultura e Lazer: Tessituras de espaços para alteridade”

PESQUISADOR RESPONSÁVEL: Eliane Dias de Castro

CARGO/ FUNÇÃO: Professor Doutor RDIDP

PESQUISADOR EXECUTANTE: Cinthia Mayumi Saito

CARGO/FUNÇÃO: Terapeuta Ocupacional

INSCRIÇÃO CONSELHO REGIONAL Nº.CREFITO 3 - 8205/TO

\section{AUTORIZAÇÃO DO USO DE IMAGEM}

Eu, portador do R.G. $n^{\circ}$ autorizo o uso de minha

imagem para análise e publicações científicas (como revistas e eventos) vinculadas ao Protocolo de Pesquisa intitulado Atividades de Cultura e Lazer: Tessituras de espaços para alteridade, desenvolvido pela terapeuta ocupacional Cinthia Mayumi Saito e sob responsabilidade da Profa. Dra. Eliane Dias de Castro.

Local e data:

Assinatura: 


\section{Anexo H.2 - Autorização do uso de imagem (de outra pessoa)}

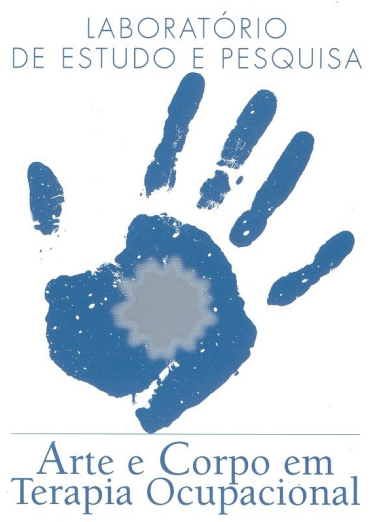

Laboratório de Estudo e Pesquisa Arte e Corpo em Terapia Ocupacional

Universidade de São Paulo - Faculdade de Medicina

DEPARTAMENTO DE FISIOTERAPIA, FONOAUDIOLOGIAE TERAPIAOCUPACIONAL

Rua Cipotânea, $\mathrm{n}^{\circ} 51$ - Cidade Universitária Cep.05360-160 - São Paulo - SP

Tel.(11) 3091-8437- Fax. (11) 3091-7415

E-mail: centroto@edu.usp.br

PROTOCOLO DE PESQUISA nº 0143 / 08:

"Atividades de Cultura e Lazer: Tessituras de espaços para alteridade"

PESQUISADOR RESPONSÁVEL: Eliane Dias de Castro

CARGO/ FUNÇÃO: Professor Doutor RDIDP

PESQUISADOR EXECUTANTE: Cinthia Mayumi Saito

CARGO/FUNÇÃO: Terapeuta Ocupacional

INSCRIÇÃO CONSELHO REGIONAL N.CREFITO 3 - 8205/TO

\section{AUTORIZAÇÃO DO USO DE IMAGEM}

$\mathrm{Eu}$, , portador do R.G. $n^{\circ}$ , autorizo o uso da imagem de , R.G. $\mathrm{n}^{\circ}$ por quem sou responsável, para análise e publicações científicas (como revistas e eventos) vinculadas ao Protocolo de Pesquisa intitulado Atividades de Cultura e Lazer: Tessituras de espaços para alteridade, desenvolvido pela terapeuta ocupacional Cinthia Mayumi Saito e sob responsabilidade da Profa. Dra. Eliane Dias de Castro.

Local e data:

Assinatura: 


\section{Anexo H - Relação de Entrevistas completas}

A transcrição completa das entrevistas não foi anexada à Dissertação, em razão do grande volume de material produzido. Foi elaborado um volume em separado, com o conteúdo das entrevistas na íntegra e está disponível para consulta com a Autora da Dissertação. 


\section{REFERÊNCIAS \\ BIBLIOGRÁFICAS ${ }^{52}$}

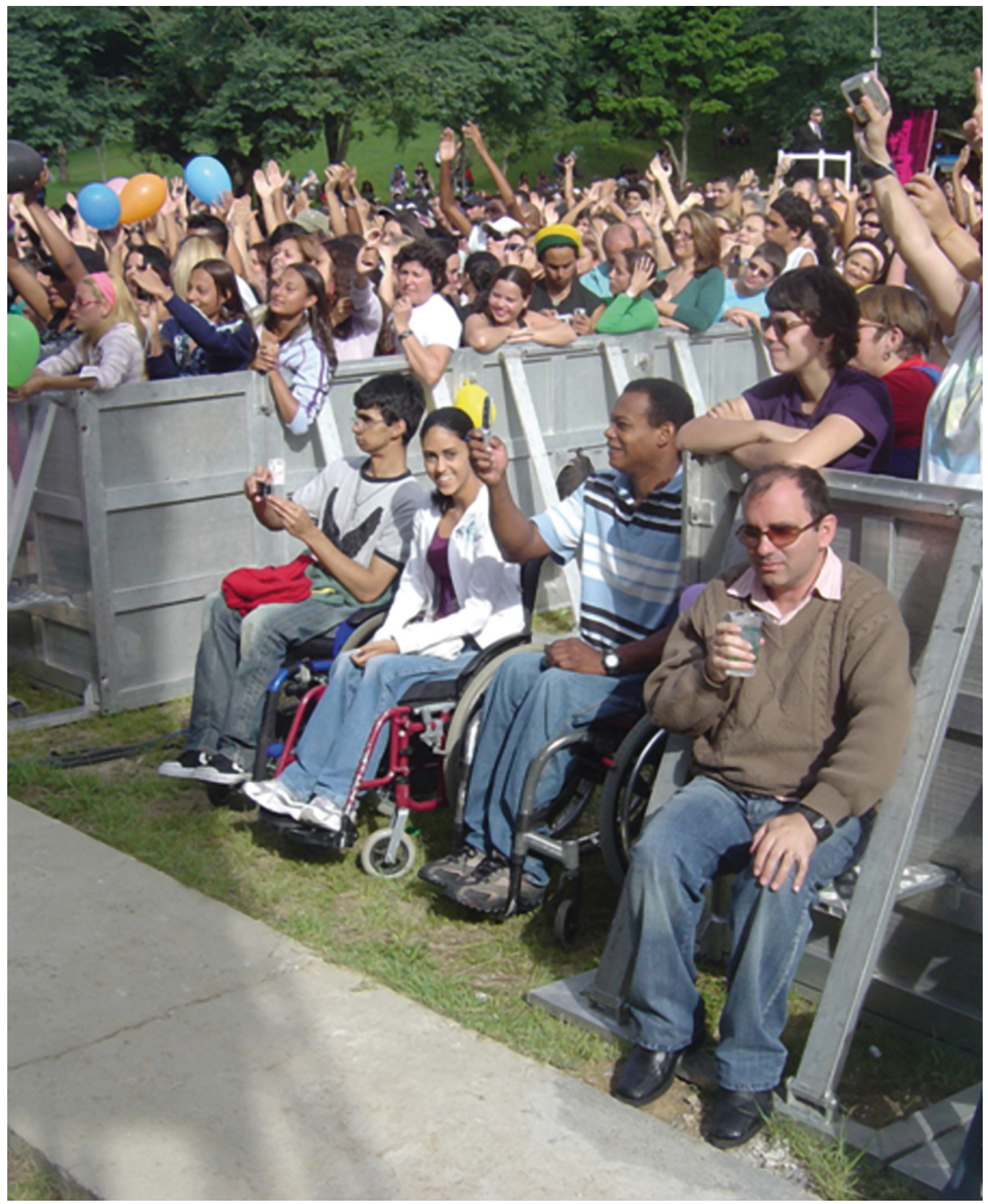

Foto 26 - Participantes do Projeto Andanças no SESC Interlagos, show de Zélia Duncan, em 2008.

$\overline{{ }^{52} \text { De acordo com: }}$

Adaptado de International Committee of Medical Journals Editors (Vancouver). Universidade de São Paulo. Faculdade de Medicina. Serviço de Biblioteca e Documentação. Guia de apresentação de dissertações, teses e monografias da FMUSP. Elaborado por Anneliese Carneiro da Cunha, Maria Julia A.L. Freddi, Maria F. Crestana, Marinalva de S. Aragão, Suely C. Cardoso, Valéria Vilhena. 2a. ed. São Paulo: Serviço de Biblioteca de Documentação; 2005. 
Abbagnano N. Dicionário de filosofia. 5ª Ed. São Paulo: Martins Fontes; 2007.

Adorno T. Tempo Livre. In: Adorno T. Indústria Cultural e Sociedade. 5a Ed. São Paulo: Paz e Terra; 2002. p.103-17.

Amaral SCF. Lazer e políticas públicas. In: Monteiro M, Dias C. (Org.) Lazer e periferia: um olhar a partir das margens. Rio de Janeiro; 2009. Mimeo.

Antunes GL. A transformação de identidade do portador de deficiência adquirida tardiamente. [Dissertação]. São Paulo: Faculdade de Saúde Pública da Universidade de São Paulo-USP; 2004.

Antunes RLC. Os sentidos do trabalho: ensaio sobre a afirmação e a negação do trabalho. 2a. Ed. São Paulo: Boitempo Editoral; 2009.

Aoki M. Reabilitação com ênfase no território - demandas de pessoas com deficiências e promoção da participação comunitária [Dissertação]. São Paulo: Faculdade de Medicina da Universidade de São Paulo-USP; 2009.

Arendt H. A Condição Humana. 10ª . Ed.Rio de Janeiro: Forense Universitária; 2000.

Batista CAM. Inclusão: construção na diversidade. Belo Horizonte: Armazém de Idéias; 2004.

Battistella LR, Britto CMM. Classificação Internacional de Funcionalidade (CIF). Acta Fisiátrica. 2002; 9 (2): 98-101.

Bogdan R, Biklen S. Investigação Qualitativa em Educação: Uma introdução à teoria e aos métodos. Porto: Porto Editora; 1994.

Brasil(Brasília). Ministério da Saúde. Secretaria de Atenção à Saúde. Política Nacional de Saúde da Pessoa Portadora de Deficiência/ Ministério da Saúde, Secretaria de Atenção à Saúde. Brasília: Editora do Ministério da Saúde; [Internet]. 2008. Disponível em: http:// bvsms.saude.gov.br/php/level.php?lang=pt\&component=51\&item=28 Acesso em: 30 set. 2009. 
Brasil (Brasília). Ministério da Saúde. Secretaria de Gestão do Trabalho e da Educação na Saúde. Departamento de Gestão da Educação na Saúde. Curso de formação de facilitadores de educação permanente em saúde: unidade de aprendizagem - análise do contexto da gestão e das práticas de saúde. Rio de Janeiro: FIOCRUZ; 2005.

Brasil. Lei no 7 853, de 24 de outubro de 1989. Dispões sobre o apoio às pessoas portadoras de deficiência, sua integração social, sobre a Coordenadoria Nacional para Integração da Pessoa Portadora de Deficiência - Corde, institui a tutela jurisdicional de interesses coletivos ou difusos dessas pessoas, disciplina a atuação do Ministério Público, define crimes e dá outras providências. Disponível em: http://www.pge.sp.gov.br/ centrodeestudos/bibliotecavirtual/dh/volume\%20i/deflei7853.htm Acesso em: 15 abr. 2010.

Caldas AL. Diário de Campo. In: Caldas AL. Calama: uma comunidade no Rio Madeira. [Tese] São Paulo: Faculdade de Filosofia, Letras e Ciências Humanas da Universidade de São Paulo-USP; 2000. Disponível em: http://www.albertolinscaldas.unir.br/ tesediariodecampo.html Acesso em: 09 maio 2007.

Calvino I. Seis Propostas para o próximo milênio: Lições americanas. São Paulo: Companhia das Letras; 1990.

Canguilhem, G. O normal e o patológico. $5^{\text {a }}$ Ed. Rio de Janeiro: Forense; 2000.

Carlo MMRP, Bartalotti CC. Caminhos da Terapia Ocupacional. In: Carlo MMRP, Bartalotti CC. (Org.) Terapia Ocupacional no Brasil: Fundamentos e Perspectivas. São Paulo: Plexus Editora; 2001.p. 19-40.

Castiglioni MC. Corpo e Deficiência: O Confronto Entre os Conceitos Espontâneos e Científicos. Rev. Ter. Ocup. Univ. São Paulo 2000; 10 (1): 17-21.

Castro SS et al. Deficiência visual, auditiva e física: prevalência e fatores associados em estudo de base populacional. Cad. Saúde Pública [on line]. 2008; 24 (8): 1773-782. Disponível em: http://www.scielosp.org/scielo.php?script=sci_arttext\&pid $=$ S0102-311X2008000800 006\&lng $=$ pt\&nrm =iso $>$. ISSN 0102-311X. doi: 10.1590/S0102-311X2008000800006. Acesso em: nov. 2009. 
Castro ED, Lima EMFA, Brunello, MIB. Atividades Humanas e Terapia Ocupacional. In: Carlo MMRP, Bartalotti CC. (Org.) Terapia Ocupacional no Brasil: Fundamentos e Perspectivas. São Paulo: Plexus Editora; 2001.p. 41- 59.

Castro ED. Atividades Artísticas e Terapia Ocupacional: construção de linguagens e inclusão social [Tese]. São Paulo: Escola de Comunicação e Artes da Universidade de São Paulo-USP; 2001.

Cavalcante FG, Marinho ASN, Bastos OM, Deus VV, Maimone MS, Carvalho MM et al Diagnóstico situacional da violência contra crianças e adolescentes com deficiência em três instituições do Rio de Janeiro. Ciênc. saúde coletiva [Internet] 2009 Fev; 14(1):4556. Disponível em: http://www.scielo.br/scielo.php?script=sci_arttext\&pid=S141381232009000100010\&lng=pt. doi: 10.1590/S1413-81232009000100010. Acesso em: 27 maio 2010.

Cavalcanti A. Avaliação da Recreação e do Lazer. In: Cavalcanti A, Galvão C. (Org.) Terapia Ocupacional: fundamentação e prática. Rio de Janeiro: Guanabara Koogan, 2007.p. 69-73.

Coletivo Nacional HumanizaSUS. Glossário. [citado 10 out 2009] Disponível em: http:// portal.saude.gov.br/portal/saude/cidadao/visualizar_texto.cfm?idtxt $=28393 \&$ janela $=1$

Cromack EMPC. Identidade, cultura surda e produção de subjetividades e educação: atravessamentos e implicações sociais. Psicol. cienc. prof., Brasília 2004 dez.;.24(4).

Couchot E. Reinventar o tempo na era digital. Interin. [Internet]. 2007 dez. Disponível em: http://www.utp.br/interin/EdicoesAnteriores/04/revista_interin.htm Acesso em:15 maio 2010.

Deleuze G. Aula sobre Spinoza. Cours Vincennes 1978 Jan. Tradução: Francisco Traverso Fuchs. Disponível em: http://www.webdeleuze.com Acesso em:05 maio 2010.

Deleuze G, Guattari F. O que é filosofia? 2a Ed. Rio de Janeiro: Editora 24; 2004. 
Douek SS. Sujeito e Alteridade em Paul Ricoeur e Emmanuel Lévinas: proximidades e distâncias [Tese]. São Paulo: Faculdade de Filosofia da Pontifícia Universidade Católica de São Paulo,SP; 2009.

Duarte R. Pesquisa qualitativa: reflexões sobre o trabalho de campo. Cad. Pesqui. [on line]. 2002;(115):139-54. Disponível em: <http://www.scielo.br/scielo.php?script=sci_ arttext\&pid=S0100-15742002000100005\&lng =en\&nrm=iso $>$.Acesso $\quad$ em: 13 abr.2010.

Dubet R. As desigualdades multiplicadas. In: Educação como exercício de diversidade. Brasília: UNESCO, MEC, ANPED, 200. 476p. (Coleção Educação para todos, v. 6).

Dumazedier J. Lazer e cultura popular. São Paulo: Perspectiva; 1976.

Farias SRR, Servo MLS. Representação social, lazer e mulheres portadoras de cegueira congênita. Rev. Baiana Saúde Pública. 2005; 29(2): 200-13.

Ferreira LHG. Enredar: "A arte de organizar encontros". Disponível em: http://www.bocc. ubi.pt/_esp/autor.php?codautor=910 Acesso em:15 maio 2010.

Figueira E. Aspectos e Mecanismos Sociais que Envolvem as Pessoas com Deficiência. Disponível em: http://www.planetaeducacao.com.br/portal/artigo.asp?artigo=1837 Acesso em:20 maio 2010 .

Freud S. O estranho (1919). In: Edição standard brasileira das obras psicológicas completas de Sigmund Freud. Tradução de Jayme Salomão. Rio de Janeiro: Imago;1995.

Galheigo SM. A transdisciplinaridade enquanto princípio e realidade das ações de saúde. Rev. Ter. Ocup. Univ. São Paulo. 1999; 10 (2/3): 49-54.

Gil AC. Como Elaborar Projetos de Pesquisa. 3ª Ed. São Paulo: Atlas; 1991.

Gohn, M. G. Empoderamento e participação da comunidade em políticas sociais. Saúde e Sociedade. 2004; 13 (2): 20-31. 
Gomes CL. Lazer, trabalho e educação: relações históricas, questões contemporâneas. $2^{\text {a }}$ Ed. Belo Horizonte: Editora UFMG; 2008.

Gomes CM, Rejowski M. Lazer Enquanto Objeto de Estudo Científico: Teses Defendidas no Brasil. Licere. 2005; 8 (2): 9-28.

Grande Dicionário Cultural Larousse da Língua Portuguesa. São Paulo: Editora Nova Cultura; 1999.

Guattari F, Rolnik S. Micropolítica: cartografias do desejo. 4ª Ed. Petrópolis: Vozes; 1996.

Guattari F. As três ecologias. 16ạ. Edição 2005, Campinas: Papirus; 1990.

Hardt M. O trabalho afetivo. In: Cadernos de Subjetividade: Reencantamento do Concreto. São Paulo: Editora Hucitec/EDUC; 2003.

Inforsato EA. Desobramento: constelações clínicas e políticas do comum. [Tese]. São Paulo: Faculdade de Educação da Universidade de São Paulo,SP; 2010.

Instituto Brasileiro de Geografia e Estatística (IBGE). Dados do Censo Demográfico 2000. Disponível em: http://www.ibge.gov.br. Acesso em:05 nov 2009.

Kinoshita RT. O Outro da Reforma: contribuições da teoria da autopoiese para a problemática da cronicidade no contexto das reformas psiquiátricas. [Tese]. Campinas: Faculdade de Ciências Médicas da Universidade Estadual de Campinas-SP; 2000.

Lancman S, Heloani R. Psicodinâmica do trabalho: o método clínico de intervenção e investigação no trabalho. Rev Produção. 2004; 14 (3): 77-86.

Law M. Learning by Doing: Creating Knowledge for Occupational Therapy. Palestra proferida no $15^{\text {th }}$ International Congress of the World Federation of Occupational Therapists. Espacio Riesco; may 6th 2010; Santiago, Chile.

Lefevre F, Lefevre AMC. Discurso do sujeito coletivo. Um novo enfoque em pesquisa qualitativa. (Desdobramentos). Caxias do Sul: Educs; 2003. 
Lefevre F; Lefevre AMC; Teixeira JJV. O Discurso do Sujeito Coletivo. Uma nova abordagem metodológica em pesquisa qualitativa. Caxias do Sul: Educs; 2000

Lima FJ, Silva FTS. Barreiras Atitudinais: obstáculos à pessoa com deficiência na escola. In: Souza, OSH. (Org.) Itinerários da Inclusão Escolar. Canoas: Editora Ulbra; Porto Alegre: Editora AGE; 2008. p. 23-32

Lima EMFA. Terapia Ocupacional e Filosofia da Diferença: Pensando uma clínica dos agenciamentos. Relatório ao Programa de Estudos Pós-Graduados em Psicologia Clínica, como parte das atividades do Pós-Doutorado, Prof. Luiz B. L. Orlandi. São Paulo: Núcleo de Estudos e Pesquisa da Subjetividade, Pontifícia Universidade Católica de São Paulo-SP; 2006.

Lima EMFA, Pastore MN. 1Atividade, Ocupação, Fazer e Ação: a discussão dos termos e dos campos das atividades humanas na Terapia Ocupacional brasileira. Relatório Final. USP-FM Depto. Fonoaudiologia, Fisioterapia e Terapia Ocupacional COSEAS - Programa de Iniciação Científica Ensinar com Pesquisa; 2010.

Lima SAB. Participação Social no Cotidiano. 5ª Ed. São Paulo: Cortez Editora; 1983.

Lüdke M, André MEDA. Pesquisa em Educação: abordagens qualitativas. São Paulo: EPU; 1986.

Magnani JGC. O (velho e bom) diário de campo. Disponível em: http://www.n-a-u.org/Magnanicadernodecampo.html\#1 Acesso em 15 jan. 2010.

Marinho ASN. Poverty, disability and violence. Ciênc. saúde coletiva [serial on the Internet]. 2009 Feb; 14(1): 21-23. Disponível em: http://www.scielosp.org/scielo. php?script $=$ sci_arttext\&pid $=$ S1413-81232009000100003\&lng $=$ en. $\quad$ doi: $10.1590 /$ S1413-81232009000100003. Acesso em: 27 maio 2010.

Martinelli SA. Inclusão: Lazer e participação social sob o olhar de pessoas com deficiência mental e suas famílias. [Dissertação]. São Carlos: Centro de Educação e Ciências Humanas da Universidade Federal de São Carlos,SP; 2008. 
Marcassa, L. As Faces do Lazer: categorias necessárias à sua compreensão. [CDRom]. In: CD-ROM XV Encontro Nacional de Recreação e Lazer (ENAREL); 2003; Santo André-SP, Brasil.

Mascarenhas F. Entre o ócio e o negócio: teses acerca da anatomia do lazer. [Tese] Campinas: Faculdade de Educação Física da Universidade Estadual de Campinas,SP; 2005. . Lazer e grupos sociais: concepções e método. [Dissertação] Campinas: Faculdade de Educação Física, Universidade Estadual de Campinas-SP; 2000.

Maturana H. Cognição, ciênicia e vida cotidiana. Belo Horizonte: Ed. UFMG; 2006.

Maturana H. Varela FJ. A árvore do conhecimento: as bases biológicas da compreensão humana. 3a Ed. São Paulo: Palas Athenas; 2003.

Minayo MCS. O desafio do conhecimento: pesquisa qualitativa em saúde. $10^{\mathrm{a}}$ Ed. São Paulo: Hucitec; 2007.

Miranda CRT, $\mathrm{Na}$ Trilha de Macunaíma: Ensaio para uma política pública de lazer [Dissertação]. Campinas: Instituto de Filosofia e Ciências Humanas da Universidade Estadual de Campinas,SP; 2004.

Muramoto MT, Mângia EF. Redes sociais e construção de projetos terapêuticos: um estudo em serviço substitutivo em saúde mental. Rev. Ter. Ocup. Univ. São Paulo. 2007; 18: 54-62.

Munnè F. Psicosociologia Del Tiempo Libre: um enfoque crítico. México: Trillas; 1980.

Neri M, Pinto A, Soares W, Costilla H. Retratos da Deficiência no Brasil. Rio de Janeiro: FGV/IBRE, CPS, 2003.

Nicácio MF, Mângia EF. Terapia Ocupacional em Saúde Mental: tendências principais e desafios contemporâneos. In: Carlo MMRP, Bartalotti CC. (Org.) Terapia Ocupacional no Brasil: Fundamentos e Perspectivas. São Paulo: Plexus Editora; 2001. p.63-80. 
Oliver F, Almeida MC. A. Abordagens comunitárias e territoriais em reabilitação de pessoas com deficiências: fundamentos para a Terapia Ocupacional. In: Carlo MMRP, Bartalotti CC. (Org.) Terapia Ocupacional no Brasil: Fundamentos e Perspectivas. São Paulo: Plexus Editora; 2001.p. 24-47

Organização Mundial da Saúde (OMS). CIF: Classificação Internacional de Funcionalidade, Incapacidade e Saúde [Centro Colaborador da Organização Mundial da Saúde para a Família de Classificações Internacionais] São Paulo: Editora da Universidade de São Paulo; 2003.

Organização das Nações Unidas (ONU). Programa de Ação Mundial para Pessoas com Deficiência. (1982). Disponível em: http://www2.camara.gov.br/comissoes/cdhm/ComBrasDirHumPolExt/ProgAcMundPessDef.html Acesso em: 06 nov. 2007

Oury J. O Coletivo. Palestra proferida no lançamento do livro "O Coletivo", na Pontifícia Universidade Católica de São Paulo (11 set 2009); São Paulo.

Padilha V. Tempo livre e capitalismo: um par imperfeito. Campinas: Alínea, 2000.

Peixoto EMM. Estudos do lazer no Brasil: apropriação da obra de Marx e Engels [Tese]. Campinas: Faculdade de Educação da Universidade Estadual de Campinas,SP; 2007.

Pélbart PP. Vida Capital: ensaios de biopolítica. São Paulo: Editora Iluminuras; 2003.

Pereira RJ. Anatomia da diferença: uma investigação teórico-descritiva da deficiência à luz do cotidiano [Doutorado]. Rio de Janeiro: Escola Nacional de Saúde Pública Sérgio Arouca, Fundação Oswaldo Cruz; 2006.

Pinto GB, Gomes CL. Lazer e Saúde: Diálogos Possíveis. IX Seminário Lazer em Debate. 2008 24-26 maio. São Paulo, Brasil. Anais. Disponível em: http://www.uspleste.usp. br/eventos/lazer-debate/anais.php Acesso em: 15 jun. 2009.

Pinto GB. Lazer e Promoção da Saúde: Um Estudo com Profissionais da Área da Saúde Humana. Licere, 2006; 9 (2): 67-80. 
Programa das Nações Unidas para o Desenvolvimento (PNUD). Desenvolvimento Humano e IDH. Disponível em: http://www.pnud.org.br/idh/ Acesso 25 abr 2010.

Pondé MP. Cardoso P. Lazer como fator de proteção da saúde mental. Rev. Ciênc. Méd. 2003; 12(2): 163-72.

Prefeitura do Município da Estância Turística de Ribeirão Pires (PMETRP). Gerência de Políticas Pública para Pessoas com Deficiência (GPPPD). Projeto Andanças: Incluir para mudar o olhar. (Projeto apresentado ao Centro de Estudos e Pesquisas de Administração Municipal - CEPAM). Ribeirão Pires; 2007.

Puhlmann F. Breve Histórico das Práticas Sociais com Relação às Pessoas com Deficiência. In: Cardoso P, Namo D. A inclusão social da pessoa com deficiência no Brasil - Como multiplicar este direito. São Paulo: Instituto Paradigma; 2008. Brasília: Secretaria Especial dos Direitos Humanos. Coordenadoria Nacional para Integração da Pessoa Portadora de Deficiência; 2008.p. 18-23.

Quarentei MS. Terapia Ocupacional e Produção de Vida. Conferência de Encerramento do VII Congresso Brasileiro de Terapia Ocupacional. Porto Alegre; 2001.

Quarentei MS. Experimentar, criar... Afirmar territórios, vidas... Belezas. 1 Seminário Aberto do Coletivo de Estudos de Terapia Ocupacional e Produção de Vida. Botucatu; Nov 2006.

Rocha EF, Castiglioni, MC. Reflexões sobre recursos tecnológicos: ajudas técnicas, tecnologia assistiva, tecnologia de assistência e tecnologia de apoio. Rev. Ter. Ocup. Univ. São Paulo. 2005; 16 (3): 97-104.

Rocha EF, Luiz A, Zulian MAR. Reflexões sobre possíveis contribuições da terapia ocupacional nos processos de inclusão escolar. Rev. Ter. Ocup. Univ. São Paulo. 2003; 14(2): $72-8$.

Rocha EF. Corpo deficiente: um desvio da norma? Rev. Ter. Ocup. Univ. São Paulo. 1991; 2 (4): 182-7. 
Rolnik S. Arte Cura? Conferência proferida no ciclo de debates sobre as exposições Zuch Tecura e the Prinzhorn Colletcion: Traces upon the Wonderblock. (original em português). Barcelona: Muse dÁrte Contemporani de Barcelona; 2001.

. Quarar a Alma in A Quietude da Terra. Museu de Arte Moderna da Bahia. Salvador, 2000.

. Com o que você pensa? Núcleo de Subjetividade da Faculdade de Psicologia da PUC-SP. Disponível em: http://blogdafla.vilabol.uol.com.br/comoquevcpensa.Suely2007.pd Acesso em: 31 ago 2008.

. O mal-estar na diferença. Chimères. Paris. 2005. Disponível em: http://www. pucsp.br/nucleodesubjetividade/Textos/SUELY/Malestardiferenca.pdf Acesso em: 23 maio 2010. . Subjetividade, Ética e Cultura nas Práticas Clínicas. Cadernos de Subjetividade [Núcleo de Estudos e Pesquisas da Subjetividade, Programa de Estudos PósGraduados de Psicologia Clínica da PUC/SP] São Paulo 1995 fev set; 3 (2): 305-14.

. Pensamento, Corpo e Devir: uma perspectiva ético/ estético/ política no trabalho acadêmico. Núcleo de Subjetividade da Faculdade de Psicologia da PUCSP; 1993. Disponível em: http://www.pucsp.br/nucleodesubjetividade/Textos/SUELY/pensamentocorpodevir.pdf Acesso em: 20 abr 2010.

Sá KO. Pressupostos Ontológicos da Produção do Conhecimento do Lazer no Brasil - 1972 a 2008: realidade e possibilidades na pós-graduação e graduação em Educação Física. [Tese]. Salvador: Faculdade de Educação da Universidade Federal da Bahia-UFBA; 2009 .

São Paulo.(SãoPaulo). Fundação Prefeito Faria Lima. Centro de Estudos e Pesquisas de Administração Municipal (CEPAM). Municípios Paulistas em Busca de Novas Práticas: II Prêmio Chopin Tavares de Lima. Novas Práticas Municipais: as doze finalistas. Ribeirão Pires: Projeto Andanças. São Paulo: Fundação Prefeito Faria Lima. Centro de Estudos e Pesquisas de Administração Municipal (CEPAM); 2007. 
São Paulo (Estado). Fundação Sistema Estadual Paulista de Análise de Dados (SEADE). Perfil Municipal. Disponível em: http://www.seade.gov.br/produtos/perfil/perfil. php Acesso em: 23 mai 2010.

Samea M. Terapia Ocupacional e grupos: em busca de espaços de subjetivação [Dissertação]. São Paulo: Instituto de Psicologia da Universidade de São Paulo-USP; 2002.

Sant'anna DB. O prazer justificado: história e lazer. São Paulo: Marco Zero; 1994.

Sant'anna DB. Corpos de Passagem: ensaios sobre a subjetividade contemporânea. São Paulo: Estação Liberdade; 2001.

Santos WR. Deficiência e BPC: o que muda na vida das pessoas atendidas. . Ciênc. saúde coletiva [Internet]; 2009 fev.. Disponível em http://www.abrasco.org.br/cienciaesaudecoletiva/artigos/artigo_int.php?id_artigo=3011 Acesso em: 27maio1010.

Sassaki RK. Inclusão, construindo uma sociedade para todos. Rio de Janeiro: WVA; 1997.

Sátiro XF. Formas de sociabilidade e instauração da alteridade: vivência das pessoas com necessidades especiais. [Tese]. Ceará: Faculdade de Farmácia, Odontologia e Enfermagem da Universidade Federal do Ceará-CE; 2004.

Sawaia B. As artimanhas da exclusão: análise psicossocial e ética da desigualdade social. Petrópolis: Vozes; 1999.

Secretaria dos Transportes Metropolitanos (STM). Estado de São Paulo.. Disponível em: http://www.stm.sp.gov.br/index.php?option=com_content\&view =article\&id = 1920:ribeirao-pires-\&catid=103\&Itemid=209, 2010 Acesso em: 13 abr 2010.

Seminário Internacional Sociedade Inclusiva IV. Propostas e ações inclusivas: impasses e avanços. 2006. Belo Horizonte, MG. Anais. Belos Horizonte: Pontifícia Universidade Católica de Minas Gerais,MG; 2006.

Silva LM. O Estranhamento causado pela deficiência: preconceito e experiência. $R e-$ vista Brasileira de Educação, 2006; 11 (33): 424-34. 
Sluzki, CE. A rede social na prática sistêmica. $3^{\circ}$ edição. São Paulo: Casa do Psicólogo, 2006.

Soares LBT. Terapia Ocupacional: lógica do capital ou do trabalho? São Paulo: Editora Hucitec; 1991.

Souza RC, Dias A, Scatena MCM. Reabilitação: uma análise do conceito. Nursing. 2001; 4 (34):26-30.

The National Science Foundation. An Overview of Quantitative and Qualitative data collection methods - Data Collection Methods: Some Tips and Comparisons. In: The National Science Foundation. The 2002 User Friendly Handbook for Project Evaluation; 2002. Disponível em: http://www.nsf.gov/pubs/2002/nsf02057/start.htm. Acesso em: 30 nov 2007.

Triviños ANS. Introdução à pesquisa em ciências sociais. São Paulo: Atlas, 1987.

Valla VV. Sobre Participação Popular: uma questão de perspectiva. Cad. Saúde Pub. 1998;14 (Sup. 2): 7-18,

Vasconcelos E M. Complexidade e pesquisa interdisciplinar: epistemologia e metodologia operativa. Petrópolis, RJ: Vozes; 2001.

Vazquez ML, Silva MRF, Campos ES, Arruda IKG, Diniz AS, Veras IL, Pereira APC. Participação social nos serviços de saúde: concepções dos usuários e líderes comunitários em dois municípios do Nordeste do Brasil. Cad. Saúde Pub. 2003 mar-abr;.19 (2): 579-91.

Watanabe M, Nicolau SM. A Terapia Ocupacional na interface da saúde e do trabalho. In: Carlo MMRP, Bartalotti CC. Terapia Ocupacional no Brasil: Fundamentos e Perspectivas. São Paulo: Plexus Editora; 2001. p.155-71.

World Federation of Occupational Therapy (WFOT). What is Occupational Therapy? Disponível em: http://www.wfot.org/information.asp. Acesso em: 2 nov 2009. 


\section{OBRAS IN REFERÊNCIA}

Arstein SR. A ladder of participation. [AmericanInstitute of Planners Journal, 35:216224, 1969]. In: Vazquez ML, Silva MRF, Campos ES, Arruda IKG, Diniz AS, Veras IL, Pereira APC. Participação social nos serviços de saúde: concepções dos usuários e líderes comunitários em dois municípios do Nordeste do Brasil. Cad. Saúde Pub. 2003 mar-abr;.19 (2): 579-91.

Barnett LA. The Playful Child: measuremente of a disposition to Play. [Play and Culture, 1991; s/v (4): 51-74]. In:Cavalcanti A. Avaliação da Recreação e do Lazer. In: Cavalcanti A, Galvão C. (Org.) Terapia Ocupacional: fundamentação e prática. Rio de Janeiro: Guanabara Koogan, 2007.

Bronder DM, Cooper KJ. Inclusion of older adults with mental retardation in leisure opportunities. [Mental Retardation, v.32, n.2, p. 91-99, 2004]. In: Martinelli SA. Inclusão: Lazer e participação social sob o olhar de pessoas com deficiência mental e suas famílias. [Dissertação]. São Carlos: Centro de Educação e Ciências Humanas da Universidade Federal de São Carlos,SP; 2008.

Bundy AC. Recreação e entretenimento: o que procurar. [In: Parham LD, Fazop. LS. A Recreação na Terapia Ocupacional. São Paulo: Editora Santos, 2002)]. In:Cavalcanti A. Avaliação da Recreação e do Lazer. In: Cavalcanti A, Galvão C. (Org.) Terapia Ocupacional: fundamentação e prática. Rio de Janeiro: Guanabara Koogan, 2007.p. 69-73.

Elias N. Sobre o tempo. [Rio de Janeiro: Jorge Zahar, 1998]. In: Antunes RLC. Os sentidos do trabalho: ensaio sobre a afirmação e a negação do trabalho. 2a. Ed. São Paulo: Boitempo Editoral; 2009.

Geertz C. Local Knowledge. Basic Books, New York, 1983. In: Magnani JGC. O (velho e bom) diário de campo. Disponível em: http://www.n-a-u.org/Magnanicadernodecampo.html\#1 Acesso em 15 jan. 2010. 
Goffman E. Estigma: notas sobre a manipulação da identidade deteriorada. [Rio de Janeiro: Zahar; 1975]. In: Rocha EF. Corpo deficiente: um desvio da norma? Rev. Ter. Ocup. Univ. São Paulo. 1991; 2 (4): 182-7.

Goldman L. Ciências humanas e filosofia. [8a Ed. São Paulo: Difel; 1980]. In: Minayo MCS. O desafio do conhecimento: pesquisa qualitativa em saúde. 10a Ed. São Paulo: Hucitec; 2007.

Hobsbawn EJ. A era dos extremos: o breve século XX (1914-1991).[ São Paulo: Companhia das Letras; 1995]. In: Peixoto EMM. Estudos do lazer no Brasil: apropriação da obra de Marx e Engels [Tese]. Campinas: Faculdade de Educação da Universidade Estadual de Campinas,SP; 2007.

Japiassu H. Interdisciplinaridade e patologia do saber. [Rio de Janeiro: Imago; 1976].In: Galheigo SM. A transdisciplinaridade enquanto princípio e realidade das ações de saúde. Rev. Ter. Ocup. Univ. São Paulo. 1999; 10 (2/3): 49-54.

Knox S. Desenvolvimento e uso correto da Escala Lúdica Pré-Escolar de Knox.[In: Parham LD, Fazop. LS. A Recreação na Terapia Ocupacional. São Paulo: Editora Santos, 2002]. In: Cavalcanti A. Avaliação da Recreação e do Lazer. In: Cavalcanti A, Galvão C. (Org.) Terapia Ocupacional: fundamentação e prática. Rio de Janeiro: Guanabara Koogan, 2007.

Kujawski GM. Crise do Século XX. 2a. ed. [São Paulo: Ática; 1991]. In: Aoki M. Reabilitação com ênfase no território - demandas de pessoas com deficiências e promoção da participação comunitária [Dissertação]. São Paulo: Faculdade de Medicina da Universidade de São Paulo-USP; 2009.

Kurz R. Os Últimos Combates.[ Rio de Janeiro: Vozes; 1997]. In: Antunes RLC. Os sentidos do trabalho: ensaio sobre a afirmação e a negação do trabalho. 2a. Ed. São Paulo: Boitempo Editoral; 2009. 
Lucáks G. The Ontology of Social Being: Labour. [Merlin Press, Londres, 1980]. In: Antunes RLC. Os sentidos do trabalho: ensaio sobre a afirmação e a negação do trabalho. 2. Ed. São Paulo: Boitempo Editoral; 2009.

Matsutsuyu JS. The Interest Check List. [American Journal of Occupational Therapy. 1969; 23(4): 323-28].In: Cavalcanti A. Avaliação da Recreação e do Lazer. In: Cavalcanti A, Galvão C. (Org.) Terapia Ocupacional: fundamentação e prática. Rio de Janeiro: Guanabara Koogan, 2007.

Marx L. O capital: a crítica da economia política. [Rio de Janeiro: Civilização Brasileira; 1971].In: Marcassa, L. As Faces do Lazer: categorias necessárias à sua compreensão. [CD-Rom]. In: CD-ROM XV Encontro Nacional de Recreação e Lazer (ENAREL); 2003; Santo André-SP, Brasil.

Medras H. La seconde révolution française, 1864-1984. [Paris, Gallimard, 1998]. In : Dubet R. As desigualdades multiplicadas. In: Educação como exercício de diversidade. Brasília: UNESCO, MEC, ANPED, 200. 476p. (Coleção Educação para todos, v. 6).

Mészáros I. Beyond Capital (Towards a Theory of Transition). [Merlin Press, Londres, 1995]. In: Antunes RLC. Os sentidos do trabalho: ensaio sobre a afirmação e a negação do trabalho. 2a. Ed. São Paulo: Boitempo Editoral; 2009.

Morin E. Epistemologia da complexidade.[In: Schnitman DF, Novos paradigmas, cultura e subjetividade. Porto Alegre: Artes Médicas; 1996]. In: Galheigo SM. A transdisciplinaridade enquanto princípio e realidade das ações de saúde. Rev. Ter. Ocup. Univ. São Paulo. 1999; 10 (2/3): 49-54.

Neto DF. Lazer: opção pessoal. [Brasília: SCE/GDF; 1993]. In: Martinelli SA. Inclusão: Lazer e participação social sob o olhar de pessoas com deficiência mental e suas famílias. [Dissertação]. São Carlos: Centro de Educação e Ciências Humanas da Universidade Federal de São Carlos,SP; 2008. 
Nicolescu B. Evolução transdisciplinar da universidade. Projeto CIRET-UNESCO; 1997. [Disponível em: http://perso.club-internet.fr/nicol/ciret/locarno/locapor4.htm]. In: Galheigo SM. A transdisciplinaridade enquanto princípio e realidade das ações de saúde. Rev. Ter. Ocup. Univ. São Paulo. 1999; 10 (2/3): 49-54.

Quijano A. Modernidade, Identidad y Utopia em América Latina. [Lima: Sociedad y Política, 1988]. Castro ED. Atividades Artísticas e Terapia Ocupacional: construção de linguagens e inclusão social [Tese]. São Paulo: Escola de Comunicação e Artes da Universidade de São Paulo-USP; 2001.

Ricoeur P. Soi-memê Comme Un Autre. [Paris: Seuil, 1990]. In: Douek SS. Sujeito e Alteridade em Paul Ricoeur e Emmanuel Lévinas: proximidades e distâncias [Tese]. São Paulo: Faculdade de Filosofia da Pontifícia Universidade Católica de São Paulo,SP; 2009.

Rogers NB, Hawkins BA, Eklund SJ. The nature of leisure in the lives of old adults with intellectual disability. Part 2. [Journal of Intellecutal Disability Research. V. 42, p. 122-130, 1998]. In: Martinelli SA. Inclusão: Lazer e participação social sob o olhar de pessoas com deficiência mental e suas famílias. [Dissertação]. São Carlos: Centro de Educação e Ciências Humanas da Universidade Federal de São Carlos,SP; 2008.

STAKE RE. Pesquisa qualitativa/naturalista - Problemas epistemológicos. Educação e Seleção, 7: 19-27, jan./jun. 1983. In: Lüdke M, André MEDA. Pesquisa em Educação: abordagens qualitativas. São Paulo: EPU; 1986.

Takata N. The Play History. [American Journal of Occupational Therapy. 1969; 23(4): 312-18]. In: Cavalcanti A. Avaliação da Recreação e do Lazer. In: Cavalcanti A, Galvão C. (Org.) Terapia Ocupacional: fundamentação e prática. Rio de Janeiro: Guanabara Koogan, 2007.

West PC. Social stigma and community recreation participation by the physically and mentally handcapped. Therapeutic Recreation Journal, v. 26, n. 1, p. 40-49, 1984]. In: Martinelli SA. Inclusão: Lazer e participação social sob o olhar de pessoas com deficiência mental e suas famílias. [Dissertação]. São Carlos: Centro de Educação e Ciências Humanas da Universidade Federal de São Carlos,SP; 2008. 


\section{Obras Consultadas}

Barthes R. O prazer do texto. 4a. Ed, São Paulo: Perspectiva; 1994.

Calvino I. As cidades invisíveis. São Paulo: Companhia das Letras; 1990.

Deleuze G. Bartleby, ou a fórmula. In: Crítica e Clínica. São Paulo: Editora 34; 1997.

Deleuze G. A literatura e a vida. In: Crítica e Clínica. São Paulo: Editora 34; 1997.

Inforsato EA. Clínica barroca: ensaios de simpatias e feitiçarias. [Dissertação]. São Paulo: Pontifícia Universidade Católica de São Paulo,SP; 2005.

Lima EMFA. Desejando a diferença: considerações a cerca das relações entre os terapeutas ocupacionais e as populações tradicionalmente atendidas por esses profissionais. Rev. Ter. Ocup. Univ. São Paulo. 2003; 14 (2): 64-71.

Lima EMFA. Terapia Ocupacional: um território de fronteira? Rev. Ter. Ocup. Univ. São Paulo. 1997; 8 (2/3): 98-100.

Marcellino NC. Lazer e Cultura: algumas aproximações. In: . Lazer e Cultura. Campinas: Editora Alínea, 2007.

Marcellino NC. Estudos do lazer: uma introdução. 4a. Ed. Campinas: Autores Associados, 2006.

Marcellino NC. Lazer e educação. Campinas: Papirus, 1987.

Melville H. Bartleby, o escriturário. 2a. Ed. Porto Alegre: L\&PM; 2008. 


\section{Fontes Primárias}

\section{Entrevistas}

- EHM. Local de trabalho, em 12 de dezembro de 2008. (Entrevista no 1).

- PACS, WRC. Residência, em 18 de dezembro de 2008. (Entrevista no 2).

- TCAM. Residência, em 16 de janeiro de 2009. (Entrevista no 3).

- MLS. Biblioteca Pública Municipal de Ribeirão Pires, em 16 de janeiro de 2009. (Entrevista no ${ }^{\text {4) }}$.

- RMM. Local de trabalho, em 05 de fevereiro de 2009. (Entrevista no 5).

- RKPS. Local de trabalho, em 05 de fevereiro de 2009. (Entrevista no 6).

- KAC. Residência, em 31 de julho de 2009. (Entrevista no 7).

- ACN. Local de trabalho, em 31 de julho de 2009. (Entrevista no 8).

- MJM. Residência, em 31 de julho de 2009. (Entrevista no 9).

- DBFS. Residência, em 12 de agosto de 2009. (Entrevista no 10).

- ASD. Local de trabalho, em 23 de agosto de 2009. (Entrevista no 11).

- CGMV. Residência, 28 de agosto de 2009. (Entrevista no 12). 


\section{Documentos}

- Diário de Campo, 2008.

- Registros do Projeto Andanças (2006-2008).

- Prefeitura do Município da Estância Turística de Ribeirão Pires (PMETRP). Gerência de Políticas Pública para Pessoas com Deficiência (GPPPD). Projeto Andanças: Incluir para mudar o olhar. (Projeto apresentado ao Centro de Estudos e Pesquisas de Administração Municipal - CEPAM). Ribeirão Pires; 2007.

- Fundação Prefeito Faria Lima. Centro de Estudos e Pesquisas de Administração Municipal (CEPAM). Municípios Paulistas em Busca de Novas Práticas: II Prêmio Chopin Tavares de Lima. Novas Práticas Municipais: as doze finalistas. Ribeirão Pires: Projeto Andanças. São Paulo: Fundação Prefeito Faria Lima. Centro de Estudos e Pesquisas de Administração Municipal (CEPAM); 2007.

\section{FOTOGRAFIAS}

Crédito aos fotógrafos:

- Paula Adriana Cunha

- Tânia Cristina A. Macedo

\section{ENTIDADES}

- Banco Real S.A.

- Base de Aviação de Taubaté (Base do Exército de Taubaté).

- Centro Cultural Banco do Brasil São Paulo (CCBB).

- Centro Cultural São Paulo (CCSP).

- Circo Spacial.

- Circo Zanni. 
- Jeep Clube de Ribeirão Pires.

- Museu de Arte Moderna de São Paulo (MAM).

- Parque Dr. Fernando Costa da Água Branca (Parque da Água Branca).

- Parque das Bicicletas.

- Parque do Ibirapuera.

- Prefeitura Municipal de Praia Grande.

- Prefeitura Municipal de Santos.

- Prefeitura Municipal da Estância Turística de Ribeirão Pires.

- Serviço Social do Comércio (SESC/SP).

- Serviço Social da Indústria (SESI).

- Teatro Alfa.

- Teatro Cenforpe.

- Sociedade de Cultura Artística (Teatro Cultura Artística).

- Teatro Folha.

- Espaço Cultura Vivo (Teatro Vivo).

\section{Sítios/Sites}

http://www.scielo.br/

http://www.pucsp.br/nucleodesubjetividade

http://www.pnud.org.br

http://bvsms.saude.gov.br

http://portal.saude.gov.br

http://www.wfot.org

http://saci.org.br

http://www.usp.br/sibi/ 